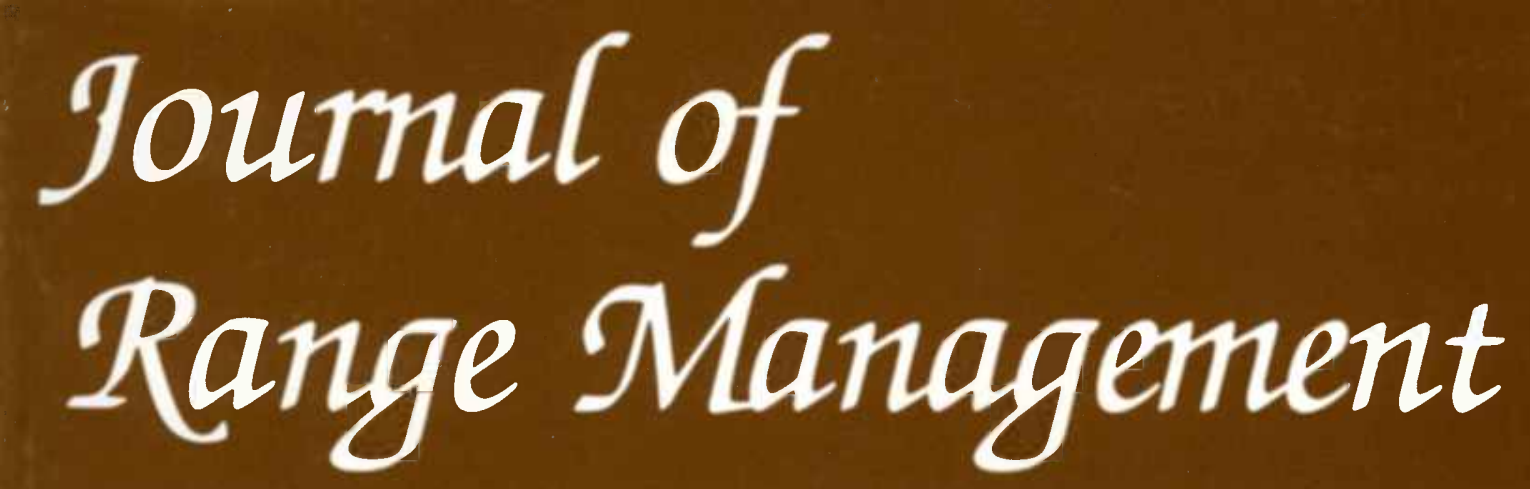

TABLE OF CONTENTS: VOL. 55, NO. 4, July 2002

FEATURE ARTICLE

318 Shrub control and streamflow on rangelands: A process based viewpoint by Bradford P. Wilcox

Animal Ecology

327 Early weaning and length of supplementation effects on beef calves by A.J. Pordomingo

336 Density and reproductive success of Florida grasshopper sparrows following fire by Michael F. Delany, Stephen B. Linda, Bill Pranty, and Dustin W. Perkins

341 Large ungulate habitat preference in Chobe National Park, Botswana by Uyapo J. Omphile and Jeff Powell

350 Plains larkspur (Delphinium geyeri) grazing by cattle in Wyoming by James A. Pfister, Dale R. Gardner, Bryan L. Stegelmeier, Anthony P. Knight, James W. Waggoner, Jr., and Jeffery O. Hall

Grazing Management

360 Elk and cattle forage use under a specialized grazing system by Lacey E. Halstead, Larry D. Howery, George B. Ruyle, Paul R. Krausman, and Robert J. Steidl

Hydrology

367 Sediment movement and filtration in a riparian meadow following cattle use by R.R. McEldowney, M. Flenniken, G.W. Frasier, M.J. Trlica, and W.C. Leininger

Measurement/Sampling

374 Calibrating fecal NIRS equations for predicting botanical composition of diets by John W. Walker, Scott D. McCoy, Karen L. Launchbaugh, Merrita J. Fraker, and Jeff Powell

383 Short-term monitoring of rangeland forage conditions with AVHRR imagery by David P. Thoma, Derek W. Bailey, Daniel S. Long, Gerald A. Nielsen, Mari P. Henry, Meagan C. Breneman, and Clifford Montagne

Plant-Animal

390 Prior feeding practices do not influence locoweed consumption by M.H. Ralphs, G. Greathouse, A.P. Knight, D. Doherty, J.D. Graham, B.L. Stegelmeier, and L.F. James 
Published bimonthly—January, March, May, July, September, November

Copyright 2002 by the Society for Range Management

INDIVIDUAL SUBSCRIPTION is by membership in the Society for Range Management.

LIBRARY or other INSTITUTIONAL SUBSCRIPTIONS on a calendar year basis are $\$ 95.00$ for the United States postpaid and $\$ 112.00$ for other countries, postpaid. Payment from outside the United States should be remitted in US dollars by international money order or draft on a New York bank.

BUSINESS CORRESPONDENCE, concerning subscriptions, advertising, reprints, back issues, and related matters, should be addressed to the Managing Editor, 445 Union Blvd., Suite 230, Lakewood, Colorado 80228.

EDITORIAL CORRESPONDENCE, concerning manuscripts or other editorial matters, should be addressed to the Editor, Gary Frasier, 7820 Stag Hollow Road, Loveland, Colorado 80538. Page proofs should be returned to the Production Editor, 3059A Hwy 92, Hotchkiss, CO 81419-9548.

INSTRUCTIONS FOR AUTHORS appear on the inside back cover of most issues. THE JOURNAL OF RANGE MANAGEMENT (ISSN 0022-409X) is published bimonthly for $\$ 56.00$ per year by the Society for Range Management, 445 Union Blvd., Ste 230, Lakewood, Colorado 80228. PERIODICALS POSTAGE paid at Denver, Colorado and additional offices.

POSTMASTER: Return entire journal with address change-Address Service Requested to Society for Range Management, 445 Union Blvd., Suite 230, Lakewood, Colorado 80228.
394 Clipping and precipitation influences on locoweed vigor, mortality and toxicity by M.H. Ralphs, D.R. Gardner, J.D. Graham, G. Greathouse, and A.P. Knight

Plant Ecology

400 Long-term impacts of livestock grazing on Chihuahuan Desert rangelands by Joseph M. Navarro, Dee Galt, Jerry Holechek, Jim McCormick, and Francisco Molinar

406 Population cycles of broom snakeweed in the Colorado Plateau and Snake River Plains by M.H. Ralphs and K.D. Sanders

412 Monitoring a half-century of change in a hardwood rangeland by Kerry L. Heise and Adina M. Merenlender

420 Fingerprint composition of seedling root exudates of selected grasses by Johan F. Dormaar, Bonnie C. Tovell, and Walter D. Willms

Book Reviews

424 Restoration Ecology and Sustainable Development. Edited by Krystyna M. Urbanska, Nigel R. Webb, and Peter J. Edward. and The Political Economy of Agricultural, Natural Resources, and Environmental Policy Analysis. By Wesley F. Peterson.

PRINTED IN USA

Editor-In-Chief
SAM ALBRECHT
445 Union Blvd., Ste 230
Lakewood, Colorado 80228
(303) 986-3309
Fax: (303) 986-3892
e-mail address:
sam_albrecht@ ix.netcom.com
Editor/Copy Editor
GARY FRASIER/JO FRASIER
7820 Stag Hollow Road
Loveland, Colorado 80538
e-mail address:
gfrasier@ @lamar.colostate.edu
Production Editor
PATTY RICH
Society for Range Management
3059A Hwy 92
Hotchkiss, Colorado 81419-9548
e-mail address:
prich@ @starband.net
Book Review Editor
DAVID L. SCARNECCHIA
Dept of Natural Res. Sci.
Washington State University
Pullman, Washington 99164-6410
e-mail address:
scarneda@ @ail.wsu.edu
Electronic JRM Editor
M. KEITH OWENS
Texas A\&M University
Research Center
1619 Garner Field Road
Ulvade, Texas
e-mail address:
m-owens @ tamu.edu

Associate Editors
YUGUANG BAI
Dept. Plant Sciences
University of Saskatchewan
51 Campus Drive
Saskatoon, Saskatchewan
S7N 5A8
CANADA

KLAAS BROERSMA

Agriculture and Agri-Food Canada 3015 Ord Rd.

Kamloops, British Columbia V2B 8A9 CANADA

JOE E. BRUMMER

Mt. Meadows Res. Ctr. P.O. Box 598

Gunnison, Colorado 81230

DAVID ELDRIDGE

Dept. Land and Water Conserv. School of Geography University of New South Wales Sydney, New South Wales 2052 AUSTRALIA

\section{ROBERT GILLEN}

USDA-ARS

Southern Plains Range Res. Sta 2000 18th Street

Woodward, Oklahoma 73801
ELAINE E. GRINGS USDA-ARS

Fort Keogh-LARRL 243 Fort Keogh Rd.

Miles City, Montana 59301

MARSHALL HAFERKAMP USDA-ARS

Fort Keogh-LARRL

243 Fort Keogh Rd.

Miles City, Montana 59301

ROBERT A. MASTERS

Dow AgroSciences LLC 3618 South $75^{\text {th }}$ Street Lincoln, Nebraska 68506

MITCHEL MCCLARAN

University of Arizona 301 Biological Science East

Tucson, Arizona 85721-0001

M. ANNE NAETH

University of Alberta

Dept. Renewable Resources

751 General Services Bldg.

Edmonton, Alberta

T6G 2H1 CANADA

ROBERT PEARCE

5028 Highway 6

Bishop, California 93514

\author{
MICHAEL H. RALPHS \\ USDA-ARS \\ Poisonous Plant Lab \\ 1150 E $1400 \mathrm{~N}$ \\ Logan, Utah 84341-2881 \\ LARRY REDMON \\ TAREC \\ P.O. Drawer E \\ Overton, Texas 74684
}

NEIL RIMBEY

University of Idaho

16952 S. 10th Ave.

Caldwell, Idaho 83607

CAROLYN HULL SIEG

S.W. Science Complex

2500 South Pine Knoll

Flagstaff, Arizona 86001

STEVE WARREN

Colorado State University

Center for Environmental

Management of Military Land

Dept. of Forestry Sciences

Fort Collins, Colorado 80523 


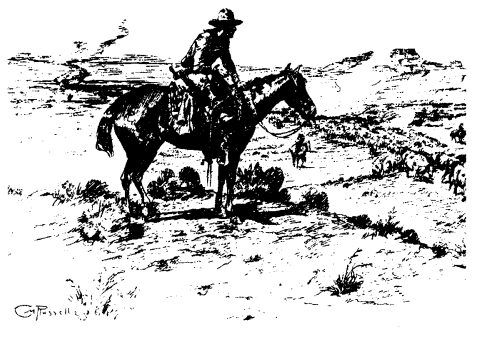

President

RODNEY K. HEITSCHMIDT

USDA-ARS

Ft. Keogh LARRL

Rt 1, Box 2021

Miles City, Montana 59301-9801

1st Vice-President

BOB BUDD

Red Canyon Ranch

350 Red Canyon Rd

Lander, Wyoming 82520-9417

2nd Vice-President

MORT KOTHMANN

Texas A\&M University

Dept. Rangeland Ecology \& Mgt.

College Station, Texas 77843-0001

Executive Vice-President

SAM ALBRECHT

445 Union Blvd. Suite 230

Lakewood, Colorado 80228-1259

(303) 986-3309

Fax: (303) 986-3892

e-mail address:

srmden@ rangelands.org

\section{Directors}

2000-2002

RICHARD H. HART

USDA-ARS

High Plains Grasslands Station

8408 Hildreth Rd.

Cheyenne, Wyoming 82009-8809

DON KIRBY

North Dakota State University

Animal \& Range Science

Fargo, North Dakota 58105

\section{1-2003}

JOHN TANAKA

Eastern Oregon Agr. Res. Center-Union

P.O. Box E

Union, Oregon 97883

\section{GREG TEGART}

BCMAFF

1690 Powick Rd, Suite 2000

Kelowna, BC V1X 7G5

CANADA

\section{2-2004}

JOHN MALECHEK

Utah State University

Dept. of Rangeland Resources

UMC 5230

Logan, Utah 84322-0001

MARTIN VAVRA

EOARC

HC 71 Box 451, Hwy 205

Burns, Oregon 97720-9807

The term of office of all elected officers and directors begins in February of each year during the Society's Annual Meeting.
THE SOCIETY FOR RANGE MANAGEMENT, founded in 1948 as the American Society of Range Management, is a nonprofit association incorporated under the laws of the State of Wyoming. It is recognized exempt from Federal income tax, as a scientific and educational organization, under the provisions of Section 501(c)(3) of the Internal Revenue Code, and also is classed as a public foundation as described in Section 509(a)(2) of the Code. The name of the Society was changed in 1971 by amendment of the Articles of Incorporation.

The objectives for which the corporation is established are:

- to properly take care of the basic rangeland resources of soil, plants, and water;

- to develop an understanding of range ecosystems and of the principles applicable to the management of range resources;

- to assist all who work with range resources to keep abreast of new findings and techniques in the science and art of range management;

-to improve the effectiveness of range management to obtain from range resources the products and values necessary for man's welfare;

-to create a public appreciation of the economic and social benefits to be obtained from the range environment;

-to promote professional development of its members.

Membership in the Society for Range Management is open to anyone engaged in or interested in any aspect of the study, management, or use of rangelands. Please contact the Executive VicePresident for details.

The Journal of Range Management is a publication of the Society for Range Management. It serves as a forum for the presentation and discussion of facts, ideas, and philosophies pertaining to the study, management, and use of rangelands and their several resources. Accordingly, all material published herein is signed and reflects the individual views of the authors and is not necessarily an official position of the Society. Manuscripts from anyone-nonmembers as well as members-are welcome and will be given every consideration by the editors. Editorial comments by an individual are also welcome and, subject to acceptance by the editor, will be published as a "Viewpoint."

In Cooperation With: Some of the articles appearing in The Journal of Range Management (JRM) are presented in cooperation with The American Forage and Grassland Council (AFGC). This cooperation consists of $J R M$ acceptance of professional papers in forage grazing management and related subject areas from AFGC members and the appointment of 2 AFGC affiliated associate editors to JRM's Editorial Staff. The American Forage and Grassland

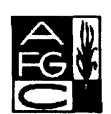
Council Offices: P.O. Box 94, Georgetown, Texas 78627; Larry Jeffries, President; Dana Tucker, Executive Secretary.

Contribution Policy: The Society for Range Management may accept donations of real and/or personal property subject to limitations set forth by State and Federal law. All donations shall be subject to management by the Executive Vice President as directed by the Board of Directors and their discretion in establishing and maintaining trusts, memorials, scholarships, or other types of funds. Individual endowments for designated purposes can be established according to Society policies. Gifts, bequests, legacies, devises, or donations not intended for establishing designated endowments will be deposited into the SRM Endowment Fund. Donations or requests for further information on Society policies can be directed to the Society for Range Management, Executive Vice-President, 445 Union Blvd., Suite 230, Lakewood, Colo. 80228-1259. We recommend that donors consult Tax Advisors in regard to any tax consideration that may result from any donation. 


\title{
Shrub control and streamflow on rangelands: A process based viewpoint
}

\author{
BRADFORD P. WILCOX
}

The author is an Associate Professor in the Rangeland Ecology and Management Department, Texas A\&M University, College Station, Tex. 77843.

\begin{abstract}
In this paper, the linkage between streamflow and shrub cover on rangelands is examined, with a focus on the extensive Texas rangelands dominated by mesquite and juniper. The conclusions drawn are consistent with results from field studies and with our understanding of runoff processes from rangelands. Whether and how shrub control will affect streamflow depends on shrub characteristics, precipitation, soils, and geology. Precipitation is perhaps the most fundamental of these factors: there is little if any real potential for increasing streamflow where annual precipitation is below about $500 \mathrm{~mm}$. For areas in which precipitation is sufficient, a crucial indicator that there is potential for increasing streamflow through shrub control is the presence of springs or groundwater flow to streams. These conditions often occur at locations where soils are shallow and underlain by fractured parent material. Under such conditions, reducing shrub cover may increase streamflows because water that would otherwise be lost through interception by the canopy instead moves into the soil and quickly travels beyond the root zone. If, on the other hand, there is no obvious subsurface connection between the hillslope and the stream channel and when runoff occurs it occurs as overland flow, shrub control will have little if any influence on streamflow. In assessing the potential for shrub control to increase streamflow, the runoff generation process should be explicitly identified. An improved understanding of the linkages between shrubs and streamflow on rangelands will require additional research on (1) hillslope hydrologic processes and how these are altered by shrub cover (2) groundwater-surface water interactions and (3) hydrologic scale relationships from the patch to the hillslope to the landscape levels.
\end{abstract}

Key Words: water yield, range hydrology, runoff, shrub control, ecohydrology, streamflow, semiarid

In this paper, I review the evidence for whether streamflow can be increased through modification of shrub cover on non-riparian rangelands. The focus is on Texas rangelands, because shrub control is viewed as a viable management option for alleviating many of the urgent water supply problems in the State. The recent drought-in conjunction with an increasing demand for water-is focusing attention on water shortages, and any management strategies that may combat these shortages elicit tremendous interest. The State is in the midst of a comprehensive water

The author gratefully acknowledges reviews of this paper by David Briske, Urs Kreuter, John Walker, Larry White, Keith Owens, and one anonymous reviewer. Manuscript accepted 10 Oct. 01.

\section{Resumen}

En este artículo se examina la conexión entre las corrientes y la cobertura de los pastizales con enfoque a los pastizales extensivos del Texas dominados por mezquite y junípero. Las conclusiones a las que se llegó son consistentes con los resultados de los estudios de campo y con nuestro entendimiento de los procesos de escurrimiento de los pastizales. Si el control de arbustos afecta, y la manera en que afectará las corrientes, depende de las características de los arbustos, la precipitación, los suelos y la geología. La precipitación es quizá el más fundamental de estos factores: Hay muy poco potencial para incrementar las corrientes en lugares donde la precipitación anual es menor de aproximadamente $500 \mathrm{~mm}$. En áreas donde la precipitación es suficiente, un indicador crucial de que hay potencial para incrementar las corrientes mediante el control de arbustos es la presencia de de manantiales o flujo de agua subterránea a las corrientes. Estas condiciones a menudo ocurren en localidades donde los suelos son someros y están sobre material parental fracturado. Bajo tales condiciones, reduciendo la cobertura de arbustos se pueden incrementar las corrientes, porque el agua que sería perdida a través de intercepción por la copa en su lugar se mueve hacia el suelo y viaja rápidamente a zonas mas alla de la zona radical. Por el contrario, si no hay una conexión subsuperficial obvia entre la pendiente de la montaña y los canales de las corrientes y que cuando el escurrimiento ocurra sea sobre la superficie terrestre, el control de arbustos tendrá poco, si no es que ninguna, influencia en las corrientes. En la evaluación del potencial del control de arbustos para incrementar las corrientes, el proceso de generación del escurrimiento debe ser explícitamente identificado. Un mejor entendimiento de las conexiones entre los arbustos y las corrientes en los pastizales requerirá de investigación adicional sobre: (1) los procesos hidrológicos en las pendientes de las montañas y como estos son alterados por la cobertura de arbustos, (2) las interacciones del agua subterránea con el agua superficial y (3) las relaciones a escala hidrológica de nivel parche a nivel montaña y hasta nivel de paisaje.

planning process designed to ensure that water is used in the most efficient manner possible and to explore options for increasing the amount of water available, one of which is shrub control.

The perception is widespread that streamflow from Texas watersheds can be significantly augmented, and therefore water supply substantially increased, through aggressive control of mesquite (Prosopis glandulosa Torr. var. glandulosa) and juniper (Juniperus ashei Buckholtz, Juniperus pinchotii Sudw). For example, some have argued that in the San Angelo area of West 
Texas, shrub control could convert now intermittent streams into perennial ones and dramatically increase the rate at which water supply reservoirs are filled (UCRA 1998). A similar argument is made regarding the Edwards Aquifer recharge area farther south. In that region, many believe that the spreading juniper communities are contributing to reduced groundwater recharge and springflow (Wright 1996).

Some recent modeling studies support this notion (UCRA 1998, Bednarz et al. 2001, Wu et al. 2001). One of these-the 1998 UCRA study-was cited as the major justification for a multi-million-dollar, state-funded program to subsidize brush control on the North Concho watershed in West Texas. And the more recent studies will certainly be taken into account as the State considers whether to allocate additional funding for brush control aimed at increasing streamflow in other regions of the State.

However, results from many field studies do not fully concur with the predictions of these modeling studies, particularly for mesquite-dominated rangelands. It is true that in humid landscapes, changes in vegetation cover-particularly from woody to herbaceous - can radically alter the water cycle (Jackson et al. 2000). For example, in humid areas of Australia the widespread replacement of Eucalyptus and other deeprooted woody species by pasture and crop species has raised the water table and led to serious salinization problems (Greenwood 1992, Walker et al. 1993). A similar relationship between timber harvesting and streamflow is well documented in many other forest types (Stednick 1996), as is the converse: declines in streamflow as a result of afforestation (Trimble et al. 1987, Calder 1990). But in drylands, the correlation between woody cover and streamflow is weaker. (Drylands are zones in which the ratio of precipitation to potential evapotranspiration is less than $0.65-$ conditions found in arid, semiarid, and even subhumid regions (Middleton and Thomas 1997). In some dryland ecosystems, such as chaparral woodlands in the southwestern United States, there is unmistakable evidence that streamflow increases when woody cover is reduced, but in other semiarid environments the linkage is tenuous at best (Blackburn 1983, Hibbert 1983). How streamflow in drylands responds to changing vegetation cover will depend on many factors, including precipitation amount and pattern, characteristics of the soil, geology, and vegetation. The amount of precipitation is especially important. In general, there is no real potential for increasing streamflow unless annual precipitation exceeds $450-500 \mathrm{~mm}$ (Hibbert 1983).

Shrub control as a water management tool does warrant serious consideration in Texas, because there are large tracts of rangeland that are in a relatively high rainfall belt, receiving $600-1,000 \mathrm{~mm}$ of precipitation a year. These areas, which were once grasslands, are now predominantly high-density shrublands in which water supply is insufficient to meet all of the competing demands. As a means of assessing the potential for success of shrub control in such regions, I have used the limited data available to (1) delineate as clearly as possible the important hydrologic processes, and (2) identify whether, how, and under what conditions shrub cover may modify those processes. The conclusions are germane not only to Texas rangelands but to other semiarid shrublands as well. Given that the programs being considered will involve large expenditures of limited public funds, investigation of the scientific basis for brush control programs is both timely and important.

\section{Background}

The widespread conversion of grasslands and savannas to shrublands during the last 50-100 years has provoked considerable debate concerning the cause(s) of these changes and given rise to a number of investigations. On the basis of several comprehensive reviews of the literature, we can conclude that the primary mechanism behind the increase in shrub cover has been a dramatic shift in patterns of herbivory and fire frequency during this time, although shifts in climate and $\mathrm{CO}_{2}$ concentrations have also been cited as possible factors (Archer 1994, Van Auken 2000). In Texas, the increase in shrub cover has been particularly pronounced for mesquite (Archer et al. 1988, Archer 1994, 1995), ashe, and redberry juniper, especially during the last 50-80 years (Ansley et al. 1995, Fuhlendorf and Smeins 1997, Smeins et al. 1997, Phillips et al. 2000).

A logical question is, "Are increases in shrub cover modifying the hydrologic cycle, and if so, in what way and to what extent?" In Texas, the perception is widespread that changes in shrub cover have led to significant and even dramatic reductions in the amount of runoff or streamflow coming from rangeland watersheds. This issue was examined in detail during the 1980 s, but at that time only a few studies had been conducted in Texas.
Blackburn (1983) conducted a thorough review of the pre-1980 literature on the linkages between streamflow and shrub cover on rangelands and concluded that much of what had been learned from other semiarid rangelands was not relevant for Texas because of the differences in climate, soils, and vegetation. In the absence of substantiated data, the major argument for the effectiveness of brush control was based on the "Rocky Creek Story" (documented by Kelton [1975]), an anecdote that has taken on mythic proportions. Rocky Creek is reported to have dried up in the 1930 s and to have remained dry until around 1960, when an extensive program of brush removal was carried out within the 74,000-acre watershed. Rocky Creek again began to flow, and has continued flowing since that time. Beginning in the 1990s, several key field studies have been conducted on Texas rangelands that provide more definitive information about the linkages between shrub cover and water yield.

\section{Relationships between Shrub Cover and Hydrologic Processes}

The hydrologic cycle and corresponding water budget are a simple yet powerful framework for examining how changes in vegetation cover influence water availability. The linkages between shrub cover and the various components of the water budget are discussed below.

Equation 1 presents a simplified interpretation of the water budget, partitioning precipitation (the major determinant of the potential for shrub removal to modify streamflow) into (1) evapotranspiration, (2) runoff, (3) groundwater, and (4) soil water:

$$
\mathrm{P}=\mathrm{ET}+\mathrm{R}+\mathrm{G}+\Delta \mathrm{S}
$$

where

$\mathrm{P}=$ Precipitation

$\mathrm{ET}=$ Evapotranspiration

$\mathrm{R}=$ Runoff

$\mathrm{G}=$ Groundwater recharge

$\Delta \mathrm{S}=$ Change in soil water storage

Evapotranspiration is a process that includes (1) evaporation from the soil, (2) transpiration from the plant, and (3) evaporation from plant or litter surfaces (commonly referred to as interception loss). As shrub cover increases, so too does the potential for transpiration and/or interception losses.

Soil water is the amount of water held in the soil, which over a period of several years or more is assumed to remain con- 
stant. Woody vegetation, by virtue of being more deeply rooted, generally extracts soil water from greater depths (provided deep water exists) than does herbaceous vegetation. Soil water that moves beyond the root zone is considered to be groundwater recharge, because eventually it will move to an underlying water body. In semiarid environments, flux rates of water moving to groundwater are very low, particularly if soils are deep and of low permeability and/or if aquifers are located at great depths (Scanlon 1994). If, on the other hand, the soils are shallow and the parent material highly permeable-as in the Edwards Plateau region of Texas-groundwater recharge may be very rapid (Maclay 1995).

Runoff is water that travels from the hillslope toward the stream channel, a portion of which (not captured by soils or evaporated en route) becomes streamflow. Runoff travels via a number of pathways, including (1) Horton overland flow, (2) saturation overland flow, (3) shallow subsurface flow, and (4) groundwater flow. Horton overland flow, which occurs when precipitation intensity exceeds soil infiltration capacity, is assumed to be the dominant mechanism of streamflow generation for most rangelands, particularly semiarid ones (Dunne 1978). Saturation overland flow occurs when soils become saturated. In more humid environments, soil saturation commonly results when a rising groundwater table brings water to the surface; this is the primary mechanism for variable-source-area runoff (Hornberger et al. 1998). Saturation overland flow may also result from the presence of a shallow impermeable horizon that prevents water from percolating down through the upper soil layer. This mechanism has been documented on some rangelands (Lopes and Ffolliott 1993) and likely occurs on many others. Shallow subsurface flow, sometimes referred to as interflow, is that portion of runoff that travels laterally through the soil, generally because of some impeding soil horizon. Shallow subsurface flow is more common in humid environments, but it can be important in semiarid environments and can be very rapid, especially when macropores are present in the soil (Wilcox et al. 1997, Newman et al. 1998).

Groundwater flow is generally the source for the base flow of a stream (prolonged flow, not attributable to a specific precipitation event), but probably is not an important pathway for storm flow (streamflow that can be directly attributed to a specific precipitation event) because the pace of groundwater travel is slow. A perennially flowing stream is an indication that groundwater flow is important, whereas one characterized by ephemeral or "flashy" flow suggests that either Horton overland flow or shallow subsurface runoff is the dominant source.

Woody vegetation may modify the runoff and groundwater recharge components of the water budget in myriad ways, direct and indirect. It may (1) alter soil infiltration characteristics, through root penetration and the addition of organic matter; (2) preserve soil moisture, through shading and mulching; (3) draw off soil moisture, through transpiration or interception; and (4) alter subsurface flow paths through root activity that leads to the formation of macropores (Blackburn 1975, Seyfried 1991, Breshears et al. 1998, Breshears and Barnes 1999, Ludwig et al. 1999, Jackson et al. 2000). But it is through modification of the evapotranspiration component that woody plants most influence streamflow. To understand the potential for augmentation of streamflow in these rangelands through removal of mesquite and juniper, therefore, it is important to examine not only how these woody plants modify runoff and groundwater recharge processes, but also how they might affect evapotranspiration.

\section{Evapotranspiration}

Environmental characteristics that favor evapotranspiration. When considering the process of evapotranspiration in semiarid and subhumid landscapes, it is important to remember that these environments are by definition soil-water-deficient, because the evaporative demand is much higher than precipitation. Figure 1, in which average monthly potential evapotranspiration (Larkin and Bomar 1983) is compared with average monthly precipitation for the San Angelo area of Texas, shows that in this area evaporative demand is about 4 times greater than precipitation. To a large extent, this disparity explains why runoff typically accounts for such a small portion of dryland water budgets-although there are exceptions, as will be discussed later. The consequence is that no matter what the vegetation cover, most of the water in a soil-water-deficient system will be lost through evapotranspiration. This fact alone would suggest that removal of shrub cover to minimize evapotranspiration in the hope of increasing streamflow has a limited chance for success, because most water stored in the soil will be either evaporated or used by whatever vegetation is present. A major exception would be a system in which conditions allow water to travel very rapidly to the stream channel, minimizing opportunities for evaporation.

An important component of total evapotranspiration is interception. Although the available data are somewhat limited, those we do have strongly indicate that interception is much higher from juniper than from mesquite rangelands. The greater interception capacity of juniper may be attributed

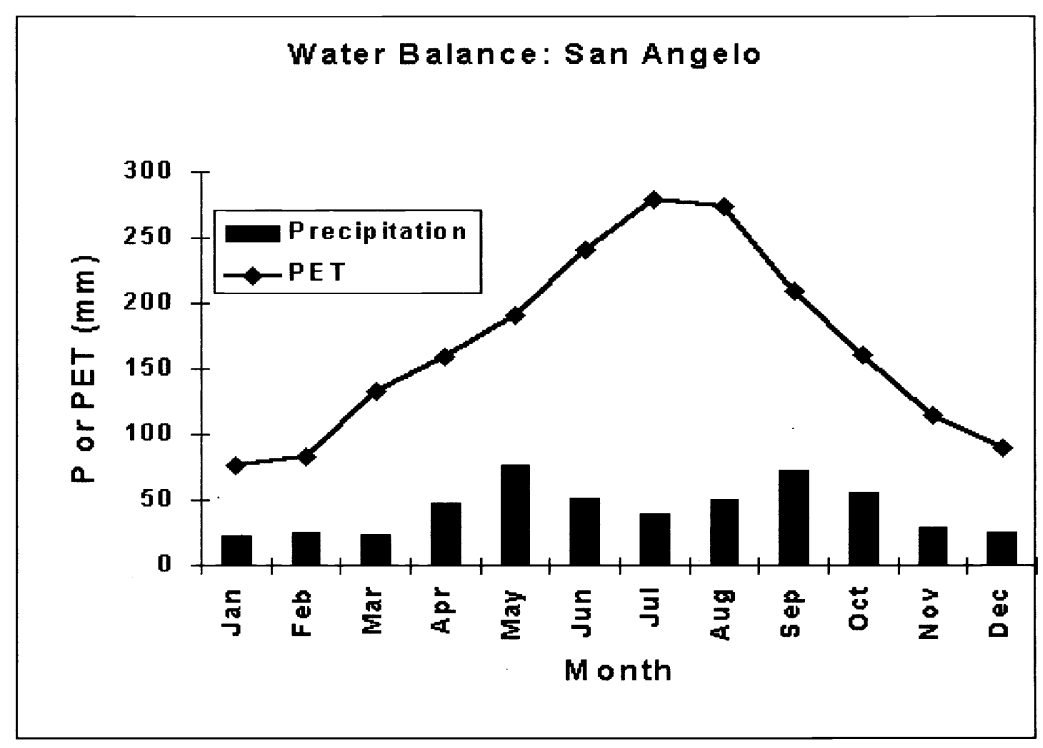

Fig. 1. Average monthly precipitation (1969-1998) and potential evapotranspiration (Larkin and Bomar, 1983) for the San Angelo area. 
to the fact that juniper is an evergreen and has a high leaf-area density. Working in the Sonora region of Texas, Thurow and Hester (1997) found that as much as $70 \%$ of the precipitation is intercepted by the juniper canopy and litter layer. Findings from other juniper rangelands, although not showing such high percentages, also suggest that capture of water by juniper canopies can be substantial (Collings 1966, Young et al. 1984). Recent work indicates that the actual percentage of interception by juniper canopies is highly dependent on the amount and intensity of precipitation (Keith Owens, personal communication). In contrast, interception by mesquite canopies is reported to be between 15 and 30\% (Desai 1992, Martinez-Meza and Whitford 1996). For both juniper and mesquite, a much smaller percentage of the precipitation is intercepted during large, high-intensity storms than during smaller, low-intensity storms.

Measuring evapotranspiration. Evapotranspiration at the plant community level can be measured directly using the Bowen Ratio approach, which is based on calculations of the energy budget (Evett 2000). Two studies, one of a mesquite rangeland (Dugas and Mayeux 1991) and the other of a juniper rangeland (Dugas et al. 1998), have used Bowen Ratio methodology to examine changes in community-level evapotranspiration rates following brush control.

For the first study, located in the Rolling Plains of Texas, mesquite was removed from one site while a second site was left untreated. Dugas and Mayeux concluded that "under circumstances of low grazing and low runoff potential, honey mesquite removal would provide little if any additional water for off-site uses in the short term." Evapotranspiration was somewhat greater from the treated site under dry conditions, but under wet conditions there was no significant difference. The small difference between the 2 sites was attributed to the vigorous growth of herbaceous vegetation following mesquite eradication on the treated site, a phenomenon noted by many other researchers documenting the effects of mesquite control in other areas of Texas (Dahl et al. 1978, Jacoby et al. 1982, McDaniel et al. 1982, Bedunah and Sosebee 1984, Heitschmidt et al. 1986, Heitschmidt and Dowhower 1991).

The second Bowen-Ratio study was in a juniper-dominated rangeland. Dugas et al. (1998) found that brush control did result in significantly lower evapotranspiration rates at the community level, but only for 2 years. The authors estimate that ground- water recharge during those 2 years was $70-130 \mathrm{~mm}$ greater than if the site had not been treated. However, it should be noted that by the third year these effects were no longer measurable because of the regrowth of herbaceous and woody vegetation.

An alternative approach to assessing the evaporative demand of shrublands is an indirect one, the water budget approach, in which all the components of the water budget except evapotranspiration are measured directly; evapotranspiration is then assumed to be the difference between the sum of these components and the total water budget. For this approach to be applied successfully on rangelands, detailed tracking of soil water is essential. Four studies have relied on the water budget approach to assess how eradication of mesquite (3 studies) or juniper (1 study) affects hydrologic processes.

The 3 studies in mesquite rangelands did not all yield similar results. In the earliest study, Richardson et al. (1979) found that in the Blackland Prairie of Texas, where annual precipitation is around $870 \mathrm{~mm}$, deep soil moisture ( $>2 \mathrm{~m}$ ) increased by about $80 \mathrm{~mm} /$ year following eradication of mesquite. In contrast, Carlson et al. (1990) found that mesquite eradication in the Rolling Plains of Texas, where average annual precipitation is around $640 \mathrm{~mm}$, had minimal if any influence on soil moisture-or, by inference, on communitylevel evapotranspiration-largely because of the flush of herbaceous growth following mesquite removal (Heitschmidt and Dowhower 1991). And the third study, by Weltz and Blackburn (1995) in south Texas (where average annual precipitation is around $700 \mathrm{~mm}$ ), found little difference in soil moisture storage or evapotranspiration between adjacent mesquite- and grassland-dominated communities. The fact that soil moisture increased in the Blackland Prairie but not in the other 2 mesquite rangelands is probably explained by the formation, during dry periods at this site, of vertical soil cracks that allow water to move deep into the soil profile.

The fourth study was the only detailed analysis of water budgets on juniper rangeland in Texas. From the results, Thurow and Hester (1997) concluded that groundwater recharge could be greatly increased through removal of all or most of the juniper cover. Following complete removal of juniper at the site, they carried out long-term measurements of soil water, by means of weighing lysimeters; of canopy and litter interception; and of surface runoff. They calculate that groundwater recharge increased by around 75 $\mathrm{mm}$ /year, a difference they attribute largely to the much greater interception of water by juniper than by grasses.

In summary, most field studies of mesquite rangelands, whether based on the energy budget or the water budget approach, have found that eradication of mesquite does not lead to increased soil moisture and groundwater recharge, unless conditions are such that water can move rapidly through the herbaceous rooting zone. For juniper rangelands, however, both the studies based on the energy budget approach (Dugas et al. 1998) and those based on the water budget approach (Thurow and Hester 1997) indicate water savings resulting from juniper eradication.

\section{Runoff}

When evaluating the impact of shrubs on streamflow, it is important to explicitly consider which runoff pathway dominates in the area being studied. For example, if most of the water in rivers and creeks is generated from storm flow (either Horton overland flow or shallow subsurface flow) rather than base flow (groundwater flow), evapotranspiration by shrubs has little effect on streamflow because water is moving through the system too rapidly to be transpired. If, on the other hand, base flow is an important component of the runoff regime, then there exists the potential for evapotranspiration by vegetation to modify streamflow.

For flood producing precipitation events, shrub cover has relatively little effect on stream discharge. Large precipitation events (generally more than $100-120 \mathrm{~mm}$ ) that result in flood conditions can overwhelm the capacity of the landscape to store water, regardless of the extent of tree or shrub cover (Leopold and Maddock 1954). This conclusion has been largely borne out by several studies (Ward 1978, Dunne 1988, Leopold 1997). In other words, the large and relatively infrequent flood events that fill many of the rangeland reservoirs would contribute essentially the same quantities of water whether shrub cover was present or absent. (This is not to say that rangeland vegetation is unimportant during these events; but that its major role is protection of the soil resource not modulation of flood flow.)

Horton overland flow. Factors that contribute to the generation of this type of flow are high-intensity precipitation and soils having low infiltration capacity, both commonly found in semiarid regions. Runoff processes in mesquite and juniper rangelands have been explicitly examined 
only rarely; nevertheless, we can be confident that Horton overland flow is an important, if not the dominant mechanism of runoff generation for the majority of these regions, on the basis of field evidence-including the presence of debris dams, signs of channel flow, and the absence of any obvious pathway for rapid subsurface flow. My personal observations of runoff during flash flooding also confirm this assertion.

Differences in overland flow between grass-dominated and shrub-dominated plots or small watersheds have been documented for several mesquite and juniper rangelands (Wright et al. 1976, Richardson et al. 1979, Carlson et al. 1990, Thurow and Hester 1997, Dugas et al. 1998). Interestingly, Horton overland flow is often reduced following shrub control because (1) herbaceous vegetation often grows vigorously after brush is removed, and the new growth enhances the infiltration capacity of surface soils; and (2) the increased surface roughness resulting from the scattered woody debris (and perhaps partly from herbaceous growth) impedes overland flow. Both Dugas et al. (1998) and Richardson et al. (1979) report dramatic reductions in Horton overland flow following juniper eradication, whereas a long-term study on small watersheds in Sonora showed that removal of juniper had little or no effect on surface runoff (Thurow, personal communication). For mesquite rangelands, Carlson et al. (1990) found that Horton overland flow was lower following mesquite eradication.

In contrast, Wright et al. (1976) found that Horton overland flow was significantly greater for 2-3 years following removal of juniper by burning, particularly on steep slopes; presumably it took this much time for the vegetation to completely recover (in addition, there would be less debris to impede flow following a burn than following mechanical treatment). In another study, in the Blackland Prairie of Texas, Richardson et al. (1979) observed a $10 \%$ increase in Horton overland flow after eradication of mesquite, which they attribute to higher soil moisture in the treated area.

For regions characterized by Horton overland flow, then, what we need to be examining is how vegetation and land use are modifying surface conditions, which are the major determinant of runoff amounts. Depending on those conditions, shrub control could result in either a decrease or an increase in Horton overland flow. Much will depend on the method of control and the follow-up management practices: if surface cover (live or dead vegetation) is encouraged and enhanced, overland flow should be reduced; if surface cover is diminished and the amount of bare ground increases, overland flow may increase. Blackburn (1983), in his review of the Texas literature, concludes that mesquite control-either decreases runoff (by increasing infiltration) or has no effect (Bedunah 1982, Brock et al. 1982, Knight et al. 1983, Franklin 1987). It is probable that many shrub-dominated rangelands, especially former grasslands and prairies that are now in a degraded condition, are experiencing greater streamflow than previously because of overall lower soil infiltration capacities. In such degraded environments, we would expect higher peak flows and "flashier," less sustained runoff.

Shallow subsurface flow. Shallow subsurface flow on rangelands has received little attention, but it obviously occurs in some areas where soils are shallow and underlain by highly permeable parent material-like the Edwards Plateau. It also makes up a small portion of streamflow in the Blackland Prairie of Texas. ' In the Edwards Plateau region, I have observed absolutely clear water flowing in stream channels in the wake of prolonged but low-intensity rains, while at the same time there was no evidence of Horton overland flow on the hillslopes. Obviously, water was traveling a subsurface route-an occurrence consistent with the presence of shallow soils underlain by permeable or fractured parent material, which allows water to travel rapidly through the subsurface to the stream channel or a groundwater body. Many of the areas occupied by juniper exhibit such characteristics. Where shallow subsurface flow is rapid, plant evapotranspiration rates would not directly influence runoff amounts. However, interception of water by the plant canopy could affect those amounts, especially in the case of juniper (Skau 1964, Young et al. 1984, Thurow and Hester 1997).

Groundwater flow. Streamflow from rangelands is by nature flashy, but for some areas-particularly the more humid ones-base flow does occur and can be important. The presence of base flow or spring flow is an important indicator of the potential for increasing streamflow by manipulating shrub cover. Base flow is prolonged and indicates relatively slow movement of the subsurface water, which means there is the potential for augmenting flow via shrub removal.

'Clarence Richardson, personal communication.
Groundwater/surface water interactions in rangelands have been little investigated, partly because of the impression that groundwater flow is not an important mechanism for runoff. Hence, there is much that we do not understand and about which we can only speculate. For example, base flow in many cases is probably provided by alluvial aquifers-but by what mechanism(s) are these aquifers recharged, and at what rates? Does recharge occur slowly via the hillslope, or does it occur quite rapidly, via the stream channel or other collection point, during a runoff event?

In many rangeland areas the soils are deep ( $>1 \mathrm{~m})$, and there is no obvious subsurface connection between them and the stream channel or groundwater aquifer. Under such conditions, little if any water moves beyond the root zone. The presence of a calcic, or especially a petrocalcic, horizon is a convincing indicator that the downward flux of water is very small. In contrast, in landscapes in which soils are shallow and the parent material is permeable or fractured, such as the Edwards Plateau, the subsurface connections to groundwater aquifers often allow for rapid recharge. Spring flow is common in such regions, as are perennial or intermittent streams. There are numerous anecdotal reports of spring flow appearing or increasing after shrub control, and such evidences have been documented for juniper rangelands on the Edwards Plateau (Wright 1996) and for piñon-juniper watersheds in Utah (McCarthy et al. 1999). That said, it is important to point out that although increased spring flow is vitally important on the local or "on site" level, it should not be looked upon as a way of increasing water supply at larger scales.

In summary, the mechanism or pathway by which water travels from the hillslope to the stream channel to a large extent dictates the degree to which shrubs may modify streamflow. Modification of the evapotranspiration regime will influence streamflow only if significant amounts of that streamflow come from subsurface water sources. Subsurface runoff has been little studied in rangelands, even though it is likely to be important-especially in the higher precipitation zones. Overland flow is probably the dominant runoff process for most rangelands, but it too has been inadequately examined or quantified. Where overland flow is the dominant runoff mechanism, modifications of shrub cover will probably have little influence on runoff. In fact, the few rangeland stud- 
ies that have documented overland flow following removal of mesquite or juniper indicate that if surface disturbance is minimal, herbaceous cover rapidly replaces the shrubs and runoff can actually be lower after shrub removal.

\section{Examples from Two Texas Watersheds}

Additional insights into runoff processes-and thus into the potential for modification of streamflow through manipulation of vegetation-may be gained via analysis of streamflow hydrographs. Below we discuss such analyses from 2 Texas watersheds: the North Concho in West Texas, near San Angelo, and the Seco Creek watershed, on the Edwards Plateau in central Texas.

The North Concho (lat. $31^{\circ} 35^{\prime} 33^{\prime \prime}$, long. $\left.100^{\circ} 38^{\prime} 12^{\prime \prime}\right)$ is a comparatively large watershed $\left(3,280 \mathrm{~km}^{2}\right)$. Average precipitation is around $500 \mathrm{~mm} /$ year, whereas average long-term runoff is only about 5 $\mathrm{mm} /$ year (i.e., only about $1 \%$ of the water budget). From the almost 80 -year period of records (USGS historical streamflow data) for the North Concho, it is apparent that runoff in this area is "flashy" (Fig. 2a shows runoff for a recent 3-year period). Many of the soils, being high in clay content, have a low infiltration capacity when wet. These soils are moderately deep and often underlain by a caliche layer with no obvious subsurface flow pathways. Channels that normally transport little or no water will periodically transport very high flows or even floodwater (Fig. 2a). Storm-flow runoff (most likely generated as Horton overland flow) makes up a large percentage of the total runoff. These large flood events are important from a watersupply standpoint, because they are the ones that fill downstream reservoirs.

On the Seco Creek Watershed (lat. $29^{\circ}$ $34^{\prime} 23^{\prime \prime}$, long. $99^{\circ} 24^{\prime} 10^{\prime \prime}$ ), runoff is also "flashy" but is sustained for considerably longer periods than in the North Concho region. Here, it makes up almost $25 \%$ of the total water budget (Fig. 2b). It is likely that runoff from the Seco Creek watershed is generated by multiple processes. Storm flow is rapid and must be accounted for by either Horton overland flow or shallow subsurface flow, both of which have been observed in the region; and groundwater flow is significant. Runoff averaging $25 \%$ of the water budget and reaching more than $50 \%$ in some years (e.g., 1992) (Brown et al. 1998) is astoundingly high for a semiarid watershed. This unusual sit-
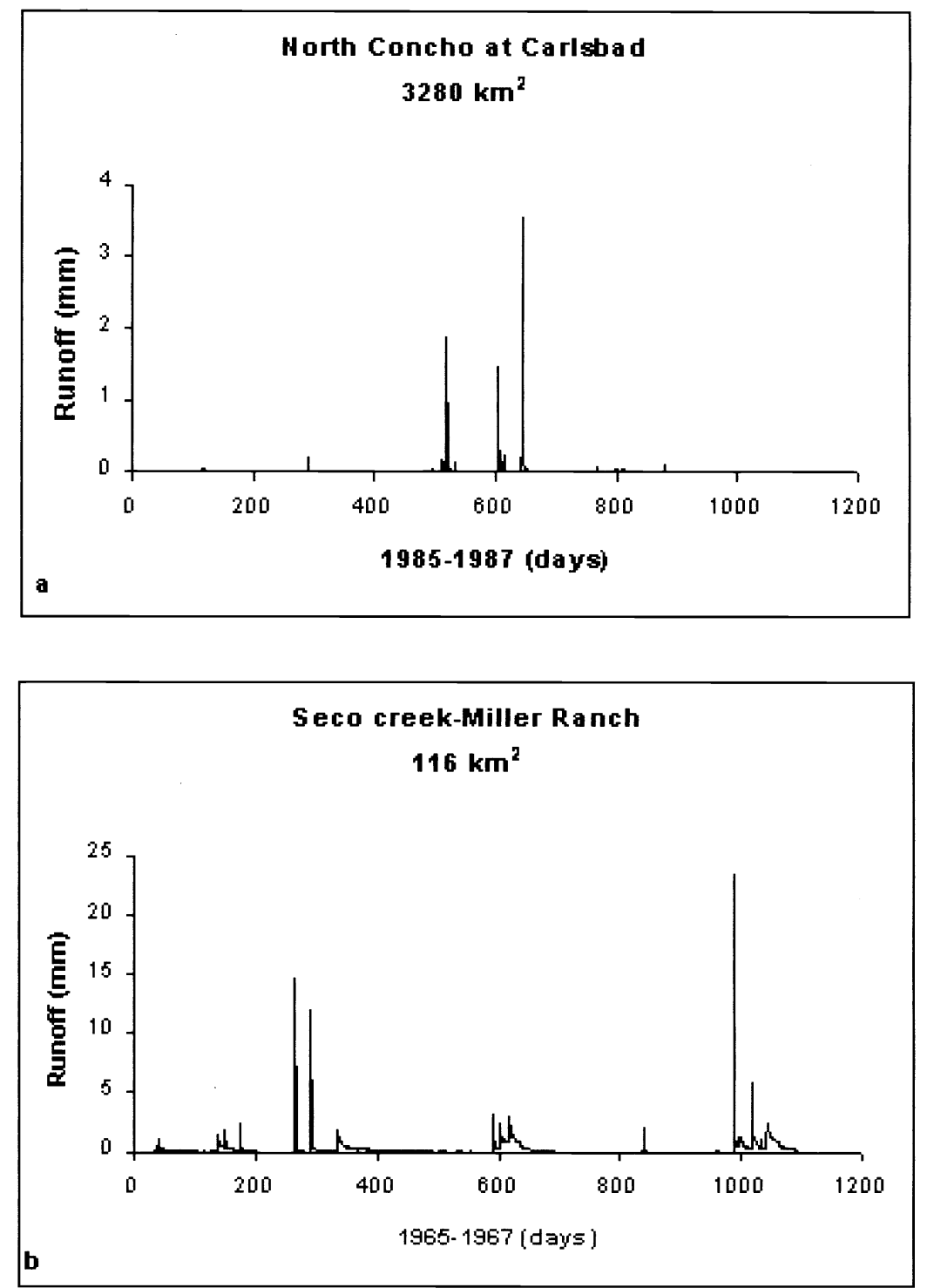

Fig. 2. Daily runoff for a 3-year period for the North Concho and the Seco River watersheds. Runoff data provided by the United States Geological Survey.

uation is explained by the low storage capacity of the soils and the high permeability of the underlying parent material. Runoff from a comparable rangeland watershed having different soil properties and parent materials would be much lower.

The strikingly different patterns of runoff from these 2 watersheds highlight the importance of considering specific site conditions when attempting to estimate the potential influence of woody vegetation on streamflow. Although runoff from both watersheds is dominated by flood events, base flow from groundwater is an important component of the water budget in Seco Creek. In contrast, at North Concho base flow is insignificant.

We can speculate, on the basis of this evidence, that on rangelands similar to the Seco Creek watershed a reduction of shrub cover has the potential for increasing streamflow and/or groundwater recharge. However, on rangelands similar to the North Concho, where runoff is primarily Horton overland flow, reduction of shrub cover would likely have little if any influence on streamflow.

\section{Summary and Conclusions}

\section{Mesquite Rangelands}

For most mesquite-dominated uplands (non-riparian), shrub control is unlikely to affect streamflow significantly, for 4 reasons: (1) evaporative demand is high, and 
the herbaceous vegetation that typically grows vigorously following eradication of the shrubs uses most of the available soil water; (2) soils on these sites are typically deep, effectively isolating the groundwater zone from the surface; (3) runoff is generated primarily as Horton overland flow; and (4) runoff is very flashy in nature: most of it is generated by flood-producing precipitation events, in amounts so overwhelming as to render insignificant the effects of other factors, such as interception by vegetation and even soil moisture storage.

\section{Juniper Rangelands}

The available field research data suggest that there is some potential for increasing streamflow from juniper rangelands. Two studies have indicated that groundwater recharge will increase following juniper removal (Thurow and Hester 1997, Dugas et al. 1998), and 1 study shows increased spring flow (Wright 1996). As yet, there have been no documented increases in streamflow as a result of juniper control, but the greater potential of these rangelands for increased streamflows or groundwater recharge is based on two factors: (1) juniper canopies have a high capacity for interception of moisture; and (2) juniper are often found in regions where soils are shallow and parent materials are permeable, features conducive to subsurface flow. A recent modeling study also concluded that increased water yields (groundwater recharge and/or streamflow) would result from a reduction in juniper cover (Wu et al. 2000).

In those regions where juniper are found on deep soils and subsurface flow does not occur, eradication is not likely to increase streamflow, for the same reasons noted earlier for deep-soil mesquite sites. But even in the shallow-soil regions, such increases will occur mainly during wet years and at relatively small scales; during dry years, and especially during droughts, it is doubtful that removal of shrub cover will affect streamflow. Further, when extra water is generated, storage of that water becomes an issue. To be available for water supply, any extra water would have to be stored either in a reservoir or as groundwater.

\section{Criteria for Successful Brush Control/Streamflow Augmentation}

For upland zones, the following factors should be considered:

1. Average amount of precipitation. As the amount of precipitation increases, the difference between the incident pre- cipitation and the amount of potential evapotranspiration diminishes (i.e., the soil water deficit becomes smaller). Hibbert (1983) has proposed as a rule of thumb that no increase in streamflow should be expected where annual precipitation is lower than $450 \mathrm{~mm} /$ year. Although Hibbert's recommendation was not based on work in Texas, it has been commonly applied to Texas conditions (Bednarz et al. 2001).

2. Amount of shrub cover. All else being equal, the clearing of a high-density stand of shrubs will have a greater effect on streamflow than will clearing of a lower-density stand.

3. Runoff and subsurface flow characteristics. If runoff occurs primarily as Horton overland flow with occasional flood events, and base flow/groundwater recharge is insignificant, streamflow will be little influenced by woody plant cover. This is probably the case for most Texas rangelands-although there are exceptions, such as the Edwards Plateau region.

4. Interception characteristics. In juniper rangelands, because the canopy is evergreen and very dense, and litter production is high, water losses through interception are very high. For mesquite rangelands, interception loss via the canopy is probably comparable to interception loss in grasslands. For this reason, removal of juniper is likely to be more effective than removal of mesquite.

\section{Future Research}

Runoff processes at the hillslope scale. For any given rangeland watershed, the dominant mechanism by which runoff is generated greatly influences that landscape's streamflow potential, erosion potential, and response to land management strategies. Relatively few studies on rangelands, however, have examined runoff processes in an explicit and detailed manner. Process-based, hillslope hydrology studies that couple detailed measurements of individual runoff events with long-term monitoring are required to gain a better understanding of runoff pathways on rangelands, especially at the hillslope and small catchment level. In New Mexico, we have attempted to implement studies of this type (Wilcox 1994, Wilcox et al. 1996a, 1996b, Wilcox et al. 1997, Newman et al. 1998, Reid et al. 1999).

Influence of shrub cover on runoff processes. It is commonly assumed that accelerated erosion and increased overland flow accompany thicketization, particular- ly in the case of juniper watershed areas. It has also been argued that increases in shrub cover reduce base flows. But actual changes in streamflow following changes in shrub cover have yet to be documented; inferences concerning this issue have been made mostly on the basis of measured changes in evapotranspiration or soil water. If such changes are occurring, we should be able to verify them through comparison with the historical record. For example, trend analysis of long-term streamflow should give some indication of whether runoff has decreased as shrub cover has increased.

Groundwater-surface water interactions. Related to the issues of runoff and vegetation cover is the question of how ground and surface waters interact within rangeland watersheds-a question especially crucial for semiarid landscapes. We cannot modify one without modifying the other (Jackson et al. 2000). We do not fully understand how alluvial aquifers are recharged (from the stream channel or from the hillslope?), nor their role in runoff generation.

Landscape-scale processes. Our understanding of vegetation and water interactions on a landscape scale is limited. For example, where streamflow may be augmented through shrub control, we do not know at what scales we would see an effect. In this paper, I have suggested that any influence of shrub cover on streamflow is likely to be at a small scale and may not manifest itself at larger scales. But these scale relationships have yet to be documented.

Finally, apart from any potential effects on streamflow, there are other reasonsand perhaps more compelling ones-to practice shrub control as a means of restoration of both mesquite and juniper rangelands in Texas. One reason-especially with regard to juniper rangelandsis to prevent thicketization, in the wake of which these rangelands quickly degenerate into areas of extremely low productivity, low plant and animal biodiversity, and generally poor wildlife habitat, posing difficult management challenges. It has been suggested, although not yet demonstrated, that under these degraded conditions overland flow is greater, erosion increases, and water quality declines.

In other words, brush control can have positive effects, but for most Texas rangelands increased streamflow is not necessarily one of them. The high soil-water deficits, high rates of evapotranspiration, weak hillslope-to-stream channel subsurface connections, and predominance of 
overland runoff of a "flashy" nature all limit the possibilities for modifying streamflow. The use of brush control in the hope of increasing streamflow should be targeted to those areas in which it is most likely to work.

\section{References}

Ansley, R.J., W.E. Pinchak, and D.N. Ueckert. 1995. Changes in redberry juniper distributions in northwest Texas. Rangelands 17:49-53.

Archer, S. 1994. Woody plant encroachment into southwestern grasslands and savannas: Rates, patterns and proximate causes, $\mathrm{p}$. 13-68, In: M. Vavra, W.A. Laycock and R.D. Pieper (eds.), Ecological Implications of Livestock Herbivory in the West. Society for Range Management, Denver, Colo.

Archer, S. 1995. Tree-grass dynamicas in a prosopis-thornscrub savanna parkland-reconstructing the past and predicting the future. Ecosci. 2:83-99.

Archer, S., C.J. Scifres, C.R. Bassham, and R. Maggio. 1988. Autogenic succession in a subtropical savanna: conversion of grassland to thorn woodland. Ecol. Mono. 58:111-127.

Bednarz, S.T., T. Dybala, R.S. Muttiah, W. Rosenthal, and W.A. Dugas. 2001. Brush/water yield feasibility studies. Blackland Res. Center, Temple, Tex.

Bedunah, J.D. 1982. Influence of some vegetation manipulation practices on the biohydrological state of a depleted deep hardland range site. Ph.D. Thesis, Texas Tech Univ., Lubbock Tex.

Bedunah, J.D. and R.E. Sosebee. 1984. Forage response of a mesquite buffalograss community following range rehabilitation. J. Range Manage. 37:483-487.

Blackburn, W.H. 1975. Factors influencing infiltration and sediment production of semiarid rangelands in Nevada. Water Resour. Res. 11:929-937.

Blackburn, W.H. 1983. Influence of brush control on hydrologic characteristics of range watersheds, p. 73-88, Brush Manage. Symp., Soc. for Range Manage. Meeting, Albuquerque, N.M.

Breshears, D.D. and F.J. Barnes. 1999. Interrelationships between plant functional types and soil moisture heterogeneity for semiarid landscapes within the grassland/forest continuum: a unified conceptual model. Landscape Ecol. 14:465-478.

Breshears, D.D., J.W. Nyhan, C.E. Heil, and B.P. Wilcox. 1998. Effects of woody plants on microclimate in a semiarid woodland: soil temperature and evaporation in canopy and intercanopy patches. Intl. J. Plant Sci. 159:1010-1017.

Brock, J.H., W.H. Blackburn, and R.H. Haas. 1982. Infiltration and sediment production on a deep hardland range site in North Central Texas. J. Range Manage. 35:195-198.
Brown, D.S., R.N. Slattery, and J.R. Gilhousen. 1998. Summary statistics and graphical comparisons of historical hydrologic and water-quality data, Seco Creek Watershed, south-central Texas. U.S. Geol. Surv., Austin, Tex.

Calder, I.R. 1990. Evaporation in the Uplands. John Wiley \& Sons, New York, N.Y.

Carlson, D.H., T.L. Thurow, R.W. Knight, and R.K. Heitschmidt. 1990. Effect of honey mesquite on the water balance of Texas Rolling Plains rangeland. J. Range Manage. 43:491-496.

Collings, M.R. 1966. Throughfall for summer thunderstorms in a juniper and pinyon woodland Cibecue Ridge, Arizona. geological survey professional paper 485-B. U.S. Dept. of the Interior.

Dahl, B.E., R.E. Sosebee, J.P. Goen, and C.S. Brumley. 1978. Will mesquite control with $2,4,5,-$ T enhance production? J. Range Manage. 31:129-131.

Desai, A.N. 1992. Interception of precipitation by mesquite dominated rangelands in the rolling plains of Texas. M.S. Thesis, Texas A\&M Univ., College Station, Tex.

Dugas, W.A. and H.S. Mayeux. 1991. Evaporation from rangeland with and without honey mesquite. J. Range Manage. 36.

Dugas, W.A., R.A. Hicks, and P. Wright. 1998. Effect of Removal of Juniperus ashei on Evapotranspiration and Runoff in the Seco Creek Watershed. Water Resour. Res. 34:1499-1506.

Dunne, T. 1978. Chapter 7. Field studies of hillslope flow processes, p. 227-293, Hillslope Hydrology. John Wiley and Sons, New York, N.Y.

Dunne, T. 1988. Geomorphological contributions to flood control planning, p. 421-438, In: V.R. Baker, R.C. Kochel and P.C. Patton (eds.), Flood Geomorphology. John Wiley and Sons, New York, N.Y.

Evett, S.R. 2000. Energy and water balances at soil-plant-atmosphere interfaces, p. A.129-A.182, In: M.E. Sumner (ed.), Handbook. of Soil Science. CRC Press, New York, N.Y.

Franklin, J.P. 1987. Consumptive water use by mesquite and grass communities in north central Texas. M.S. Thesis, Texas A\&M Univer., College Station, Tex.

Fuhlendorf, S.D. and F.E. Smeins. 1997. Long-term vegetation dynamics mediated by herbivores, weather and fire in a juniperusquercus savanna. J. Veg. Sci. 8:819-828.

Greenwood, E.A.N. 1992. Deforestation, revegetation, water balance, and climate: an optimistic path through the plausible, impracticable, and controversial. Advances in Bioclimatology 1:89-154.

Heitschmidt, R.K. and S.L. Dowhower. 1991. Herbage response following control of honey mesquite within single tree lysimeters. J. Range Manage. 44:144-149.

Heitschmidt, R.K., R.D. Schultz, and C.J. Scifres. 1986. Herbaceous biomass dynamics and net primary production following chemical control of honey mesquite. J. Range Manage. 39:67-71.
Hibbert, A.R. 1983. Water yield improvement potential by vegetation management on wester rangelands. Water Resour. Bull. 19:375-381.

Hornberger, G.M., J.P. Raffensperger, P.L. Wilberg, and K.N. Eshleman. 1998. Elements of Physical Hydrology. The John Hopkins Univ. Press, Baltimore, Md.

Jackson, R.B., H.J. Schenk, E.G. Jobbagy, J. Canadell, G.D. Colello, R.E. Dickinson, C.B. Field, P. Friedlingstein, M. Heimann, K. Hibbard, D.W. Kicklighter, A. Kleidon, R.P. Neilson, W.J. Parton, O.E. Sala, and M.T. Sykes. 2000. Belowground consequences of vegetation change and their treatment in models. Ecol. Appl. 10:470-483.

Jacoby, P.W., C.H. Meadors, M.A. Foster, and F.S. Hartmann. 1982. Honey mesquite control and forage response in Crane County, Texas. J. Range Manage. 35:424-426.

Kelton, E. 1975. The story of Rocky Creek. The Practicing Nutr. 9:1-5.

Knight, R.W., W.H. Blackburn, and C.J. Scifres. 1983. Infiltration rates and sediment production following herbicide/fire brush treatments. J. Range Manage. 36:154-157.

Larkin, T.J. and G.W. Bomar. 1983. Climatic Atlas of Texas. Texas Dept. of Water Resour.

Leopold, L.B. 1997. Water, Rivers and Creeks. Univ. Sci. Books, Sausalito, Calif.

Leopold, L.B. and T. Maddock. 1954. The Flood Control Controversy; Big Dams, Little Dams, and Land Management. The Ronald Press Company, New York, N.Y.

Lopes, V.L. and P.F. Ffolliott. 1993. Sediment rating curves for a clearcut Ponderosa pine watershed in northern Arizona. Water Resour. Bull. 29:369-382.

Ludwig, J.A., D.J. Tongway, and S.G. Marsden. 1999. Stripes, strands or stipples: modelling the influence of three landscape banding patterns on resource capture and productivity in semi-arid woodlands, Australia. Catena 37:257-273.

Maclay, R.W. 1995. Geology and Hydrology of the Edwards Aquifer in the San Antonio Area, Texas. Water-Resour. Invest. Rep. 954186. U.S. Geol. Surv., Austin, Tex.

Martinez-Meza, E. and W.G. Whitford. 1996. Stemflow, throughfall and channelization of stemflow by roots in three Chihuahuan Desert shrubs. J. Arid Environ. 32:271-287.

McCarthy, F.J., J.P. Dobrowolski, and P. Figures. 1999. Ground water source areas and flow paths to springs rejuvenated by juniper removal at Johnson Pass, Utah Olsen DS, Potyondy JP. Wildl. Hydro., Proceed.. p. 5 .

McDaniel, K.C., J.H. Brock, and R.H. Haas. 1982. Changes in vegetation and grazing capacity following honey mesquite control. J. Range Manage. 35:551-557.

Middleton, N.J. and D.S.G. Thomas. 1997. World Atlas of Desertification. Edward Arnold, London.

Newman, B.D., A.R. Campbell, and B.P. Wilcox. 1998. Lateral subsurface flow pathways in a semiarid ponderosa pine hillslope. Water Resour. Res. 34:3485-3496. 
Phillips, R.A., D.N. Ueckert, and C.B. Scott. 2000. Long-term changes in Redberry Juniper canopy cover in western Texas Publ. No R-8. Angelo State Univ.; Manage., Instruction and Res. Center, San Angelo, Tex.

Reid, K. D., B. P. Wilcox, D. D. Breshears, and L. MacDonald. 1999. Runoff and erosion for vegetation patch types in a piñonjuniper woodland. Soil Sci.Soc. Amer. J. 63:1869-1878.

Richardson, C.W., E. Burnett, and R.W. Bovey. 1979. Hydrologic effects of brush control on Texas rangelands. Trans. ASAE:315-319.

Scanlon, B.R. 1994. Water and heat fluxes in desert soils 1. field studies. Water Resour. Res. 30:709-719.

Seyfried, M.S. 1991. Infiltration patterns from simulated rainfall on a semiarid rangeland soil. Soil Sci. Soc. Amer. J. 55:1726-1734.

Skau, C.M. 1964. Interception, thoughfall, and stemflow in Utah and Alligator juniper cover types of northern Arizona. Forest Sci. 10:283-287.

Smeins, F.E., S.D. Fuhlendorf, and C.A. Taylor. 1997. Environmental and land use changes: a long-term perspective, $p$. 1.3-1.21, Juniper Symposium. Vol. Tech Rep. 97-1. Texas A\&M Univ., San Angelo, Tex.
Stednick, J.D. 1996. Monitoring the Effects of Timber Harvest on Annual Water Yield. J. Hydro. 176:79-95.

Thurow, T.L. and J.W. Hester. 1997. How an increase or a reduction in juniper cover alters rangeland hydrology, p. 9-22, Juniper Symp. Proc. Texas A\&M Univ., San Angelo, Tex.

Trimble, S.W., F.H. Weirich, and B.L. Hoag 1987. Reforestation and the reduction of water yield on the Southern Piedmont since circa 1940. Water Resour. Res. 23:425-437.

UCRA. 1998. North Concho River Watershed: Brush Control Planning, Assessment and Feasibility Study. Upper Colorado River Authority, San Angelo, Tex.

Van Auken, O.W. 2000. Shrub invasions of North American semiarid grasslands. Ann. Rev. Ecol. \& Systematics 31:197-215.

Walker, J., F. Bullen, and B.G. Williams. 1993. Ecohydrological changes in the Murray-Darling Basin. I. The number of trees cleared over tow centruies. J. Appl. Ecol. 30:265-273.

Ward, R.C. 1978. Floods, A Geographical Perspective. John Wiley and Sons, New York, N.Y.

Weltz, M.A. and W.H. Blackburn. 1995. Water budget for south Texas rangelands. J. Range Manage. 48:45-52.

Wilcox, B.P. 1994. Runoff and erosion in intercanopy zones of pinyon-juniper woodlands. J. Range Manage. 47:285-295.
Wilcox, B.P., J. Pitlick, C.D. Allen, and D.W. Davenport. 1996a. Runoff and erosion from a rapidly eroding pinyon-juniper hillslope, $\mathrm{pp}$. 61-71, In: M.G. Anderson and S.M. Brooks (eds.), Advances in Hillslope Processes. John Wiley \& Sons, New York, N.Y.

Wilcox, B.P., B.D. Newman, D. Brandes, D.W. Davenport, and K. Reid. 1997. Runoff from a semiarid ponderosa pine hillslope in New Mexico. Water Resour. Res. 33:2301-2314.

Wilcox, B.P., B.D. Newman, C.D. Allen, K.D. Reid, D. Brandes, J. Pitlick, and D.W. Davenport. 1996b. Runoff and erosion on the Pajarito Plateau: observations from the field, p. 433-439, Geology of the Los Alamos-Jemez Mountains Region.

Wright, H.A., F.M. Churchill, and W.C. Stevens. 1976. Effect of prescribed burning on sediment, water yield, and water quality from dozed juniper lands in central Texas. $\mathbf{J}$. Range Manage. 29:294-298.

Wright, P.N. 1996. Spring enhancement in the Seco Creek water quality demonstration project. Annual Project Rep.. Seco Creek Water Quality Demonstration Project.

Wu, X.B., E.J. Redeker, and T.L. Thurow. 2001. Vegetation and water yield dynamics in an Edwards Plateau watershed. J. Range Manage. 54:98-105.

Young, J.A., R.A. Evans, and D.A. Eash. 1984. Stem flow on western juniper (Juniperus occidentalis) trees. Weed. Sci 32:320-327. 


\title{
Early weaning and length of supplementation effects on beef calves
}

\author{
A.J. PORDOMINGO
}

Author is Research Scientist of National Institute of Agricultural Research, INTA Anguil, C.C. 11, Anguil (6326), La Pampa, Argentina.

\begin{abstract}
Early weaning of calves can improve reproduction of beef cows, and would be of no detriment to calf growth if the diet is adequate. Digestible energy intake could be limiting, however, when calves are weaned on forage. Performance of calves weaned at 70 days (early weaning) and 172 days (normally weaning) of age were compared. Calves from 2 locations in Argentina, Anguil, and Chacharramendi, were distributed in 14 groups and half were weaned. Early-weaned calves were pen fed a $50 \%$ concentrate-50\% alfalfa hay diet for 12 days, followed by grazing on alfalfa for 150 days. During the first 90 days on pasture, earlyweaned calves were group supplemented $(1.2 \%$ body weight (BW, DM basis). Calves from Anguil did not differ $(P=0.068)$ in average daily gain (ADG). In contrast, early-weaned calves from Chacharramendi gained faster than normally-weaned calves $(\mathrm{P}<$ 0.01). In a second experiment, 108 calves were classified into 3 age groups on day 0 of trial (AGE1 $=109 \pm 2.2$ days of age, AGE2 $=91 \pm 1.6$ days of age and AGE3 $=75 \pm 3.8$ days of age). Two thirds of the calves were weaned (early-weaned calves) the same day and the remaining third was returned to their dams (normally-weaned calves). Two feeding treatments were imposed on the early-weaned calves: S15 = supplement during the first 15 days on pasture ( $1 \%$ body weight, DM basis), and S45 = supplement during the first $\mathbf{4 5}$ days. Early-weaned calves grazed on an alfalfa pasture for 136 days. Calves from the normally-weaned group remained with their mothers until weaning onto pasture on day 87 of the study. Normally-weaned calves were the heaviest $(P<0.05)$ at the end of trial. Differences in body weight between early weaning ages increased as the supplementation period decreased. Calves that were weaned at 75 days of age and fed supplement for only 15 days had the lowest $(P<0.05)$ overall ADG and final body weight. Overall results suggested that early weaning favors reproduction of thin cows, and early-weaned calves can be placed on good-quality pasture with no detriment of growth if energy supplement is provided.
\end{abstract}

Key Words: Calf growth, calf diet, calf supplementation, beef cattle

This research was funded by National Institute of Agricultural Research. INTA Anguil, La Pampa. Author wishes to thank Carlos Urquiza and his personnel for assistance during field data collection. Appreciation is also extended to Associate Editor Dr. Elaine Grings for her invaluable assistance in reviewing and editing this manuscript.

Manuscript accepted 15 Sept. 01.
Resumen

El destete precoz mejora la eficiencia reproductiva del rodeo y no sería detrimental del crecimiento del ternero si la dieta es adecuada. Sin embargo, cuando los terneros son destetados a forraje, el consumo de energía digestible podría ser limitante del crecimiento. En este estudio se comparó la performance de terneros destetados a los 70 días (destete precoz) o a los 172 días de vida (destete normal). Terneros provenientes de 2 localidades de la provincia de La Pampa en Argentina, Anguil y Chacharramendi, fueron distribuidos en 14 grupos y la mitad se destetaron. Los terneros destetados precozmente fueron alimentados a corral con una dieta $\mathbf{5 0 \%}$ concentrado $\mathbf{- 5 0 \%}$ heno de alfalfa durante 12 días y pasaron luego a pastorear alfalfa por 150 días más. Durante los primeros 90 días sobre la pastura, recibieron un suplemento en grupo $(1,2 \%$ de peso vivo en base seca). Los terneros provenientes de Anguil no difirieron $(P=$ 0.06) en aumento de peso (ADP). En contraste, los terneros provenientes de Chacharramendi destetados precozmente aumentaron a un ritmo mayor $(P<0,01)$ que los destetados normalmente. En un segundo experimento, 108 terneros fueron clasificados en 3 grupos de edad el día 0 del ensayo (EDAD1 = $109 \pm 2,2$ días, EDAD2 $=91 \pm 1,6$ días y EDAD3 $=75 \pm 3.8$ días $)$. Dos tratamientos de suplementación fueron impuestos sobre los terneros destetados precozmente: $\mathbf{S 1 5}=$ suplementación durante 15 días sobre pastura ( $1 \%$ del peso vivo en base seca) y $\mathbf{S 4 5}=$ suplementación durante 45 días. Los terneros de destete precoz pastorearon sobre alfalfa durante 136 días. Los terneros del grupo de destete normal se mantuvieron con sus madres hasta el día 87 del ensayo, momento en el que fueron destetados y trasladados a una pastura de alfalfa (sin suplementación). Los terneros destetados normalmente fueron los más pesados al finalizar el experimento. las diferencias de peso entre edades al momento del destete precoz se incrementaron con el período de suplementación. Los terneros que fueron destetados a los 75 días de vida y suplementados por sólo 15 días tuvieron los menores ( $P$ $<0,05$ ) aumentos de peso y pesos más bajos al finalizar el ensayo. Los resultados de ambas experiencias sugirieron que el destete precoz favorece la reproducción de vacas delgadas y que los terneros destetados precozmente no sufrirían un retraso de su crecimiento si se ofrece un forraje de alta calidad y se provee un suplemento energético.

Early weaning of calves can improve reproduction rates of thin cows (Laster et al. 1973, Lusby and Wetteman 1980, Lusby and Parra 1981, Lusby et al. 1981, 1990, Peterson et al. 1987), and allow for increases in stocking rate (Monje et al. 1978, Hofer et al. 1984, Kugler et al. 1997b). Lusby and Wetteman (1980), and Gill et al. (1993) demonstrated that weaning as early as 55 days 
of age is not detrimental to calf growth. Moreover, early-weaned calves on a highconcentrate diet can gain weight faster than normally weaned calves before weaning (Myers et al. 1999a, 1999b) or even on a finishing program after weaning (Fluharty et al. 2000). Most of this work, however, was done using feedlot diets followed by a feedlot program. Little research has been done with early-weaned calves and high forage diets. The greater the roughage content of the early-weaned calf diet, the lower total energy intake and rate of gain. Hofer et al. (1984) and Monje et al. (1993) showed that early-weaned calves should be placed on good quality pasture and provided supplemental energy if good gains are desired. This research was conducted: a) to evaluate performance of early-weaned calves on pasture with limited amounts of supplementation, and b) to study the interaction between age at weaning and supplementation period on average daily gain of calves. The impact of early weaning on body condition score changes of the dams grazing rangeland at 2 locations was also evaluated.

\section{Materials and Methods}

\section{Experiment 1}

Performance of early-weaned calves weaned at 70 days of age was compared with calves weaned at the normal age of 180 days. Additionally, the impact of early weaning on cow body condition score was evaluated. This trial started on the second week of December and took place during the spring of 1995, and summer and fall of 1996, at INTA (National Institute for Agriculture Research) Anguil Experiment Station. Calves came from of 2 different locations: Anguil, located in the subhumid temperate area of central Argentina (Latitude $36^{\circ} 30^{\prime} \mathrm{S}$ Longitude $63^{\circ} 59^{\prime} \mathrm{W}$, and $165 \mathrm{~m}$ above sea level ; mean annual rainfall $=608 \pm 154 \mathrm{~mm}$, Roberto et al. 1996), and Chacharramendi, located in the semiarid temperate area of the country (Latitude $37^{\circ} 22^{\prime} \mathrm{S}$ Longitude $65^{\circ} 49^{\prime} \mathrm{W}$ and $242 \mathrm{~m}$ above sea level; mean annual rainfall $=465 \pm 143 \mathrm{~mm}$, Roberto et al. 1996).

Medium-frame 5-to-7-year old Angus cows that had calved within a 14-day period, were selected from the herds at Anguil and Chacharramendi. Seventy-two cows were selected at Anguil and 96 cows at Chacharramendi. At both locations, cows grazed on native grassland with no supplemental feed. At about 70 days of age (day
0 of trial: Anguil calves $=70.3 \pm 2.82$, Chacharramendi calves $=70.4 \pm 2.73$ days of age), all calves were weighed and assigned to groups of 12 calves each, with 6 groups in Anguil and 8 groups in Chacharramendi. Groups were made as homogeneous as possible in weight and age of calves within location. Age and body condition of cows were also accounted for in making groups as homogeneous as possible prior to final allocation of calves to treatments. Groups were considered experimental units and were then assigned to either early weaning or normally-weaning treatments at each location.

Body condition of cows was recorded by individual palpation and observation, according to the 9-point body-condition score (BCS) scale: 1 = severely emaciated to $9=$ very obese. At both locations, cows BCS were determined on days $-63,-33,0$, 42,72 , and 102 of the trial at both locations. Day -63 was day 7 of the calving period. At the time about $60 \%$ of the cows had given birth. Cows were exposed to Angus bulls ( 3 and 4 bulls for Anguil and Chacharramendi, respectively) during an 84-day period beginning on day 3 of the trial. Cows were pregnancy checked by rectal palpation 75 days after the end of breeding.

To evaluate diet quality at the 2 locations, fecal samples were collected from 20 cows at random from each herd at the same time of body condition scoring from October to March. Immediately after collection, samples were dried at $60^{\circ} \mathrm{C}$ for 48 hours and ground in a Wiley mill to pass a 1-mm screen. Similar aliquots in weight from each fecal sample were taken and composited into a pooled sample for each location and sampling time. Micro-histological analysis was performed on the pooled sample to determine botanical composition and relative proportions of main species and species classes. Samples

Table 1. Composition of feed and forages provided to early-weaned calves.

Experiment 1

\begin{tabular}{lccccc}
\hline \hline & $\mathrm{CP}^{1}$ & NDF & ADF & ME & Available forage \\
\hline Concentrate feed $^{2}$ & $(\%)$ & $(\%)$ & $(\%)$ & $\left(\mathrm{Mcal} \mathrm{kg} \mathrm{DM}^{-1}\right)$ & $\left(\mathrm{kg} \mathrm{DM} \mathrm{ha}^{-1}\right)$ \\
Alfalfa hay $_{\text {Mixed supplement }}{ }^{3}$ & 18.2 & 15.0 & 8.0 & 2.97 & \\
$\quad$ Alfalfa pasture & 17.5 & 50.3 & 40.3 & 2.08 & \\
December 1995 & 18.0 & 19.2 & 10.3 & 2.92 & \\
January 1996 & 17.8 & 47.8 & 38.2 & & \\
February 1996 & 15.1 & 55.1 & 43.2 & 1.99 & 2850 \\
\hline
\end{tabular}

${ }^{1} \mathrm{CP}=$ crude protein $($ Kjeldhal $\mathrm{N} * 6.25), \mathrm{NDF}=$ Neutral detergent fiber, $\mathrm{ADF}=$ Acid detergent fiber, $\mathrm{ME}=$ Metabolizable energy (NRC 1996). All nutrients are expressed on DM basis.

${ }^{2}$ Commercial feed based on: oat grain, sorghum grain, corn, sunflower meal and soybean meal, mineral salt, Ca and $\mathrm{P}$ organic sources, and a vitamin- micro mineral premix.

${ }^{3}$ Mixed feed composition: $40 \%$ oats, $40 \%$ corn, $18 \%$ soybean meal, $1 \%$ vitamin-mineral premix. 
weaned calves were placed in their corresponding alfalfa pasture until the end of trial (day 162).

Early-weaned calves were supplemented daily during the first 90 days on pasture. Supplement was offered at $1.2 \%$ of average body weight on DM basis within group. Supplement quantity was adjusted every 15 days based on actual BW or calculated BW assuming an ADG of $500 \mathrm{~g}$. For the first 10 days on pasture, the supplement was the same as that fed in drylot. Afterwards, a concentrate mixture based on oat grain, corn and soybean meal was fed (Table 1). The supplement was offered once daily at 1100 hours. A mixture of $50 \%$ salt and $50 \%$ bone meal was present in feeders at all times.

Calves on the normally-weaning treatment were weaned on day 102 of trial (172 \pm 2.73 days of age), which also coincided with the last day of supplementation of early-weaned calves. Normally weaned calves were placed on pasture in assigned paddocks, which had been grazed by nonexperimental steers to remove accumulated mature forage and promote growth of high-quality forage, similar to forage being grazed by early-weaned calves. Groups grazed simultaneously for an additional 60-day period.

All calves were weighed at the beginning of the experiment and on days 42,72 , 102,132 , and 162 of trial, equivalent to days $30,60,90,120$, and 150 on pasture for early-weaned calves. First body weight measurements were taken 5 hours after weaning, but all other BW were recorded after a 17-hour fast without access to feed and water.

Beginning on day 10 of the study, forage DM availability of alfalfa was determined every 30 days. Five $1-\mathrm{m}^{2}$ quadrants per paddock were hand-clipped to a $5-\mathrm{cm}$ height and weighed to determine yield. One sub-sample was taken to determine DM (AOAC 1990), while another was reserved for chemical analysis. Samples of feed offered in pens during the 12-day pen feeding period was taken every 4 days and samples of the supplement offered on pasture were taken every 15 days. These samples were oven dried at $60^{\circ} \mathrm{C}$ to determine DM content and kept for later chemical analysis. Forage samples from each paddock were composited within sampling period. Composites were analyzed for $\mathrm{CP}$ (AOAC 1990), neutral detergent fiber (NDF) (Robertson and Van Soest 1981), and acid detergent fiber (ADF) (Goering and Van Soest 1970) and in vitro DM digestibility (IVDMD) (Tilley and Terry 1963). Metabolizable energy (ME) was calculated from IVDMD estimates (NRC 1996)

\section{Experiment 2}

This trial took place at INTA Anguil Experiment Station. The objective of the study was to determine the effects of age at early weaning and length of supplementation period on calf performance. One hundred and eight medium-frame Angus calves (70 to 105 days of age) were classified into 3 age groups on day 0 of trial. Age groups were defined as: AGE1 $=111$ \pm 2.2 days of age (oldest), AGE2 $=91 \pm$ 1.6 days of age (intermediate), and AGE3 $=75 \pm 3.8$ days of age (youngest). Two thirds of the calves from each age group were weaned(early-weaned calves) the same day and the remaining third was returned to the dams for later weaning (normally-weaned calves). After a penfeeding period of 12 days, early-weaned calves grazed on an alfalfa pasture for 136 days. Two supplementation periods were imposed on the early-weaned calves: S15 $=$ supplement during the first 15 days on pasture (1\% of body weight, DM basis), and $\mathrm{S} 45=$ supplement during the first 45 days on pasture. Supplementation of S15 and S45 calves were concluded on day 27 and 57 , respectively.

Calves from the normally-weaned group, remained with their mothers on native rangeland until weaning onto pasture on day 87 of the study. At that time, age groups averaged 196, 178, and 162 days of age for age groups, AGE1, AGE2 and AGE3, respectively. Comparisons of performance of calves weaned at less than 100 days of age with calves weaned at ages ranging from 5 to 7 months were of interest for inferences to an ample array of cow-calf programs common in our region.

The design assumed supplementation periods (S15 and S45) and nursing as 3 feeding alternatives crossed by 3 age groups. The combination of 3 age groups x 3 feeding alternatives resulted in 9 treatments with 12 calves each. Calves within each treatment were blocked by weight at

Table 2. Composition of feed and forages provided to early-weaned calves.

Experiment 2

\begin{tabular}{lcccc}
\hline \hline & $\mathrm{CP}^{1}$ & NDF & ADF & ME \\
\hline & $(\%)$ & $(\%)$ & $(\%)$ & (Mcal kg DM $^{-1}$ ) \\
Concentrate feed $^{2}$ & 18.2 & 15.0 & 8.0 & 2.97 \\
Alfalfa hay & 17.2 & 48.2 & 39.1 & 2.11 \\
Alfalfa pasture & & & & 2.18 \\
December 1996 & 18.2 & 45.1 & 36.6 & 2.06 \\
January 1997 & 16.1 & 55.0 & 42.4 & 2.14 \\
February 1997 & 16.3 & 47.3 & 37.8 & 2.24 \\
March 1997 & 17.8 & 43.1 & 34.3 & \\
\hline
\end{tabular}

${ }^{\mathrm{CP}}=$ crude protein, $\mathrm{NDF}=$ Neutral detergent fiber, $\mathrm{ADF}=$ Acid detergent fiber, $\mathrm{ME}=$ calculated metabolizable energy (NRC 1996). All nutrients are expressed on DM basis.

Commercial feed based on: oat grain, sorghum grain, corn, sunflower meal and soybean meal. Included also: mineral salt, $\mathrm{Ca}$ and $\mathrm{P}$ organic sources, and a vitamin- micro mineral premix. initiation of the experiment in 3 weight groups, with 4 calves each. These groups were defined as experimental units.

Early-weaned calves were fed a diet of $50 \%$ chopped alfalfa hay and $50 \%$ concentrate for 12 days (Table 2), followed by grazing of alfalfa pasture for 136 days with supplementation according to treatments. A 40-ha pasture was divided in 27 paddocks (1.45 ha each). Paddocks were assigned randomly to each experimental unit. Supplemental feed (Table 2) was the same concentrate as in pens, offered at $1 \%$ of BW (on DM basis) daily at 1100 hours, calculated on the group BW average.

Immediately after weaning, normallyweaned calves were distributed in the previously assigned weight block within age group and moved to the corresponding alfalfa paddock. Paddocks had been grazed by non-experimental steers before arrival of calves to remove accumulated mature forage, encourage regrowth and maintain forage quality. Calves from normally-weaned group remained on pasture for 49 days (day 148 of trial - end of the study), and received no supplemental feed at any time.

All calves were weighed and weights recorded on days $0,27,57,87,117$, and 148 of trial, comprising 5 periods. Procedures for animal weighing, and alfalfa pasture and feed sampling were the same as described in Experiment 1.

\section{Statistical Analysis}

Data of each experiment were statistically analyzed using GLM procedures of SAS (1991) for repeated measures ANOVA. Calf group served as experimental units in each trial. Factor means were separated using LSD (predicted difference method, SAS 1991) when significant $(\mathrm{P}<$ $0.05) \mathrm{F}$ tests were observed. Body weight and ADG of Experiment 1 were analyzed under a randomized complete block design, with weaning treatment as main 
effect, location, and period in the sub-plot (repeated measures factor). Treatment effect, treatment $x$ location, calf group(treatment), period, treatment $\mathrm{x}$ period and the 3-way interaction (treatment $\mathrm{x}$ location $\mathrm{x}$ period) were included in the model. One-way ANOVA was performed by location and period if an interaction weaning treatment $\mathrm{x}$ location $\mathrm{x}$ period was noted $(\mathrm{P}<0.05)$. Effects of diet shifts were also assessed by ANOVA of period effect using GLM procedure of SAS (1991). The model included period, calf group(period), location and period x location. If an interaction of period by location was detected $(\mathrm{P}<0.05)$, interaction means were reported.

Experiment 2 was designed as a completely randomized design with a $3 \times 3$ factorial arrangement of treatments (AGE $x$ FA) in the main plot and period in the sub-plot (repeated measures). Factors AGE, FA and the AGE x FA interaction, period, and the 3-way interaction (FA $x$ AGE $x$ Period) were included in the model. Period effects were analyzed within FA by ANOVA with GLM of SAS with a completely randomized design. Interaction means were reported if a meaningful interaction was detected $(\mathrm{P}<$ $0.05)$.

\section{Results and Discussion}

\section{Experiment 1}

At initiation of the experiment, age of cows was very similar between treatments within location (Anguil $=5.96 \pm 0.745$ years, $(\mathrm{P}=0.875)$; Chacharramendi $=6.01$ \pm 0.736 years; $P=0.890)$. Body condition of cows was also similar (Anguil $=5.42 \pm$ $0.576, \mathrm{P}=0.710$; Chacharramendi $=3.85$ $\pm 0.405, \mathrm{P}=0.6154)$. Calf body weight did not differ either (Anguil $=77.1 \pm 0.11$ $\mathrm{kg}, \quad \mathrm{P}=0.492$; Chacharramendi $=77.6 \pm$ $0.12 \mathrm{~kg}, \mathrm{P}=0.766$ ) among weaning treatments within location at day 0 .

Supply of alfalfa forage was adequate to ensure that both forage quality and quantity did not restrict calf growth (Table 1). A significant interaction $(\mathrm{P}<0.01)$ was detected between location and weaning treatment for calf performance, therefore, weaning effects are reported by location (Tables 3 and 4). Performance of earlyweaned calves from Anguil and Chacharramendi herd was similar $(\mathrm{P}=$ 0.89 ) from day 10 to day 102 of trial when the supplementation was being fed on pasture (Table 3).
Table 3. Average daily gain $\left(\mathrm{g} \mathrm{animal}^{-1}\right)$ of Angus calves weaned at $70(\mathrm{EW})$ or $172(\mathrm{NW})$ days of age from 2 locations 1 .

\begin{tabular}{|c|c|c|c|}
\hline Day of trial & EW calves $^{1}$ & NW & $\mathrm{SE}^{2}$ \\
\hline $\begin{array}{l}0 \text { to } 42 \\
42 \text { to } 72 \\
72 \text { to } 102 \\
102 \text { to } 132 \\
132 \text { to } 162 \\
\mathrm{SE}^{3} \\
0 \text { to } 102 \\
102 \text { to } 162 \\
0 \text { to } 162\end{array}$ & $\begin{array}{l}598^{\mathrm{bA}} \\
592^{\mathrm{bA}} \\
632^{\mathrm{cA}} \\
528^{\mathrm{aA}} \\
527^{\mathrm{aA}} \\
7.9 \\
607^{\mathrm{A}} \\
527^{\mathrm{A}} \\
577^{\mathrm{A}}\end{array}$ & 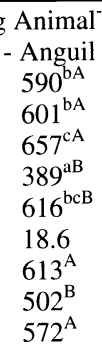 & $\begin{array}{c}10.8 \\
6.6 \\
10.9 \\
16.7 \\
8.0 \\
\\
4.5 \\
5.3 \\
4.8\end{array}$ \\
\hline $\begin{array}{l}0 \text { to } 42 \\
42 \text { to } 72 \\
72 \text { to } 102 \\
102 \text { to } 132 \\
132 \text { to } 162 \\
\text { SE } \\
0 \text { to } 102 \\
102 \text { to } 162 \\
0 \text { to } 162\end{array}$ & $\begin{array}{l}592^{\mathrm{bA}} \\
602^{\mathrm{bA}} \\
632^{\mathrm{cA}} \\
54^{\mathrm{aA}} \\
540^{\mathrm{aA}} \\
7.6 \\
607^{\mathrm{A}} \\
540^{\mathrm{A}} \\
582^{\mathrm{A}}\end{array}$ & $\begin{array}{c}\text { hacharran } \\
371^{\mathrm{bB}} \\
364^{\mathrm{bB}} \\
337^{\mathrm{aB}} \\
336^{\mathrm{aB}} \\
477^{\mathrm{BB}} \\
7.1 \\
359^{\mathrm{B}} \\
407^{\mathrm{B}} \\
377^{\mathrm{B}}\end{array}$ & $\begin{array}{r}9.4 \\
5.7 \\
9.4 \\
14.4 \\
7.0\end{array}$ \\
\hline
\end{tabular}

${ }^{\mathrm{A}}$ treatment $\mathrm{x}$ location $\mathrm{x}$ period interaction was detected $(\mathrm{P}<0.001)$; therefore treatment means are reported by location and period.

${ }^{2} \mathrm{SE}=$ Standard error for weaning effect within period and location

${ }^{3} \mathrm{SE}=$ Standard error for period effect within weaning treatment and location.

${ }^{a b c}$ Means in columns within weaning treatment and location with different lowercase superscripts differ $(\mathrm{P}<0.05)$.

${ }^{\mathrm{AB}}$ Means in rows with different uppercase superscript differ $(\mathrm{P}<0.05)$.

\section{Anguil}

Cows from Anguil were in good body condition at early weaning time and remained in good condition until all calves were weaned (Table 5). However, differences in BCS in favor of cows from the early weaning treatment were noted $(\mathrm{P}<$ $0.05)$ as time progressed. Pregnancy rate was $97 \%$ and $92 \%$ for cows from early weaning and normal weaning treatments, respectively. Table 6 shows composition and quality of the plant classes that com- prised the diet of Anguil cows during spring and summer. Most of the native forage available was perennial grasses. Crude protein and IVDMD data indicated that quality would have not been a limiting factor for milk production and body condition retention on the cows, and it did not imposed major restrictions to the calves' forage intake.

No differences between treatments were detected $(\mathrm{P}=0.33)$ in ADG of calves for the first 102 days of trial (Table 3 ).
Table 4. Live weight $(\mathrm{kg})$ of calves weaned at $70(\mathrm{EW})$ or $172(\mathrm{NW})$ days of age from 2 locations ${ }^{1}$.

\begin{tabular}{|c|c|c|c|}
\hline Day of trial & EW & NW & $\mathrm{SE}^{2}$ \\
\hline & \multicolumn{3}{|c|}{$\begin{array}{l}- \\
-\end{array}$} \\
\hline 0 & 77.1 & 77.2 & 0.06 \\
\hline 42 & 102.2 & 101.9 & 0.46 \\
\hline 72 & 120.2 & 120.4 & 0.47 \\
\hline 102 & 139.0 & 139.7 & 0.44 \\
\hline 132 & 154.8 & $151.4 * *$ & 0.26 \\
\hline \multirow[t]{2}{*}{162} & 170.6 & 169.8 & 0.28 \\
\hline & \multicolumn{3}{|c|}{ 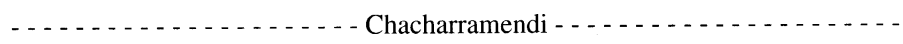 } \\
\hline 0 & 77.6 & 77.7 & 0.05 \\
\hline 42 & 102.5 & $93.2 * *$ & 0.40 \\
\hline 72 & 120.6 & $104.2 * *$ & 0.41 \\
\hline 102 & 139.5 & $114.3 * *$ & 3.38 \\
\hline 132 & 155.7 & $124.4 * *$ & 0.22 \\
\hline 162 & 171.9 & $138.7^{* *}$ & 0.24 \\
\hline
\end{tabular}

${ }^{A}$ treatment $x$ location $x$ period interaction was detected $(\mathrm{P}<0.001)$; therefore treatment means are reported by location and period

${ }^{2} \mathrm{SE}=$ Standard error

** Means in rows differ $(\mathrm{P}<0.01)$ 
Table 5. Body condition scores (BCS) ${ }^{1}$ of cows with calves weaned at 70 (EW) or 172 (NW) days of age at 2 locations, Anguil and Chacharramendi.

\begin{tabular}{|c|c|c|c|c|}
\hline $\begin{array}{l}\text { Day after } \\
\text { calving }\end{array}$ & $\begin{array}{c}\text { Day of } \\
\text { trial }^{3}\end{array}$ & $\overline{E \text { EW }}$ & NW & $\mathrm{SE}^{2}$ \\
\hline 1 & -63 & 5.67 & 5.64 & 0.12 \\
\hline 30 & -33 & 5.53 & 5.50 & 0.11 \\
\hline 63 & 0 & 5.42 & 5.47 & 0.10 \\
\hline 105 & 42 & 5.47 & 5.36 & 0.10 \\
\hline 135 & 72 & $5.58 \mathrm{a}$ & $5.19 b$ & 0.10 \\
\hline \multirow[t]{2}{*}{165} & 102 & $5.61 \mathrm{a}$ & $5.03 \mathrm{~b}$ & 0.10 \\
\hline & $-\ldots$ & $\ldots$ & i - . - - - & $\ldots$ \\
\hline 1 & -63 & 5.07 & 5.17 & 0.08 \\
\hline 30 & -33 & 4.89 & 4.94 & 0.09 \\
\hline 63 & 0 & 4.40 & 4.44 & 0.09 \\
\hline 105 & 42 & 3.83 & 3.88 & 0.06 \\
\hline 135 & 72 & $4.52 \mathrm{a}$ & $3.80 \mathrm{~b}$ & 0.06 \\
\hline 165 & 102 & $5.05 \mathrm{a}$ & $3.72 b$ & 0.07 \\
\hline
\end{tabular}

Body condition score: $1=$ severely emaciated, $2=$ emaciated, $3=$ very thin, $4=$ thin, $5=$ moderate, $6=$ good, $7=$ very good, $8=$ obese, 9 = very obese

${ }^{2} \mathrm{SE}=$ Standard error

${ }^{3}$ Day 0 of trial were dates December 4th and 5th for locations Anguil and Chacharramendi, respectively.

${ }^{\mathrm{a}, \mathrm{b}}$ Means in rows with different superscript differ $(\mathrm{P}<0.05)$

Likewise, calf treatment groups from Anguil did not differ $(\mathrm{P}=0.48)$ in $\mathrm{BW}$ at day 0 or days 42,72 , and 102 (Table 4 ).

On day 102, supplemental feeding of early-weaned calves was concluded and normally-weaned calves were weaned. Comparisons across periods within weaning treatment indicated that diet switch resulted in reduction $(\mathrm{P}<0.01)$ of gain for the following 30 -day period in both groups (Table 3). Feeding normally-weaned calves after weaning on alfalfa forage without supplemental feed, had a greater depressive effect $(\mathrm{P}=0.016)$ on $\mathrm{ADG}$ than supplement elimination for early-weaned calves grazed on the same forage. Normally-weaned calves appeared to express compensatory growth the following 30 days, showing greater $(P=0.015)$ ADG than early-weaned calves. Overall, performance of early-weaned and normally-weaned calves was similar $(\mathrm{P}=0.168)$.

\section{Chacharramendi}

Weaning treatment groups from Chacharramendi were similar $(P=0.77)$ in average body weight of calves at early weaning time (Table 4). Early-weaned calves, however, gained more $(\mathrm{P}<0.01)$ than normally-weaned calves over the study (Table 3 ). At normal weaning time (day 102 of trial; 172 days of age), earlyweaned calves averaged $25 \mathrm{~kg}$ heavier than normally-weaned calves (Table 4). The ADG of early-weaned calves was almost twice $(\mathrm{P}<0.01)$ that of normally-weaned calves during this period (Table 3 ).

The area suffered a 5-month drought during spring and summer. Although spring is statistically the rainy season $(54 \%$ of the annual rainfall) (Roberto et al. 1996), Spring 1995 was unusually dry. The accumulated rainfall at the ranch for Spring 1995 and Summer 1996 was 58\% $(202 \mathrm{~mm})$ of the 80 -year average $(345 \mathrm{~mm}$; Roberto et al. 1996). The Chacharramendi cow herd lost 0.7 units of body condition (from $5.1 \pm 0.2$ to $4.4 \pm 0.56$ ) from calving to day 0 of trial (Table 5). Early weaning allowed the cows to recuperate body condition during summer. Cows that remained with their calves continued to lose condition up to weaning (day 165 after calving). Pregnancy results reflected the body condition differences $(91 \%$ and $44 \%$ for cows on early weaning and normal weaning treatments, respectively.)

Although not measured directly, a reduced forage availability and quality would have restricted milk production and calf's feed intake, which would have been detrimental for calf growth. Microhistology on fecal samples from parturition to the normal weaning time pointed out an increased presence of shrubs in the diet during the late spring and summer months (Table 6), which could indicate a sizable reduction of grass availability. Although shrubs provided a greater proportion of crude protein than perennial grasses, lignin content also increased and digestibility decreased. Compared with the diet of the herd at Anguil, the cow herd at Chacharramendi had a lower quality forage available from calving and throughout the study.

Normally-weaned calves from Chacharramendi suffered a diet adjustment effect as did normally-weaned calves from Anguil during the 30-day period after weaning. Gains of early-weaned calves did not improve in this period compared with the previous one (Table 3 ). This group expressed some compensatory growth in the last 30-day period of the study, but not as great as in Anguil. This increase did not compensate for the reduced rate of growth that took place up to weaning. Over the study, ADG of earlyweaned calves was $54 \%$ greater than gain of normally-weaned calves (Table 3). At the end of trial, early-weaned calves were $33.2 \mathrm{~kg}$ heavier $(\mathrm{P}<0.01)$ than normallyweaned ones (Table 4 ).

Results from our study would indicate that early-weaned calves grazing good quality pastures and supplemented for a 90-day period would grow at a rate similar to normally-weaned calves if cows can maintain good body condition through lactation. Moreover, ADG of early-weaned calves could be superior to ADG of normally-weaned calves if cows were under nutritional stress. Fernández and Zuccari (1996), in a similar environment and weaning program, reported no differences in weight gain of Angus calves weaned from first calf heifers at 60 days of age and supplemented on pasture during 60 days, compared with calves weaned at 6 months of age. Daily gains reported were $679 \mathrm{~g}_{\text {animal }}{ }^{-1}$ for early-weaned vs $670 \mathrm{~g}$ animal $^{-1}$ for normally-weaned calves. In a similar study, Fernández et al. (1997) reported ADG of 646 and $644 \mathrm{~g} \mathrm{animal}^{-1}$ for early-weaned and normally-weaned calves.

In Oklahoma, Lusby and Wettemann (1980) reported similar rates of growth up to 7 months of age for normally-weaned calves and calves weaned at $56 \mathrm{~kg}$ body weight (6 to 8 weeks of age). Drylot-fed early-weaned calves gained weight at a rate of $667 \mathrm{~g} \mathrm{day}^{-1}$.

In a more restrictive environment than ours (Province of Río Negro, Argentina) and a similar feeding program, Kugler et al. (1997a) reported greater ADG for 69day old early-weaned calves compared with normally-weaned calves (745 vs 580 $\mathrm{g}$ animal $\left.{ }^{-1}\right)$. After weaning, the earlyweaned calf group was supplemented during 60 days on pasture. In contrast, Sciotti et al. (1996) reported lower ADG for early-weaned calves supplemented for 30 days on pasture compared with normallyweaned calves ( 578 vs $635 \mathrm{~g}^{\text {animal }}{ }^{-1}$ ). Working in a more humid area of Argentina, Hidalgo et al. (1996) reported better performance of normally-weaned calves than early-weaned calves (900 vs $493 \mathrm{~g} \mathrm{day}^{-1}$ ). 
Table 6 . Botanical composition1, and quality of forage classes and estimated diet of beef cows at 2 locations.

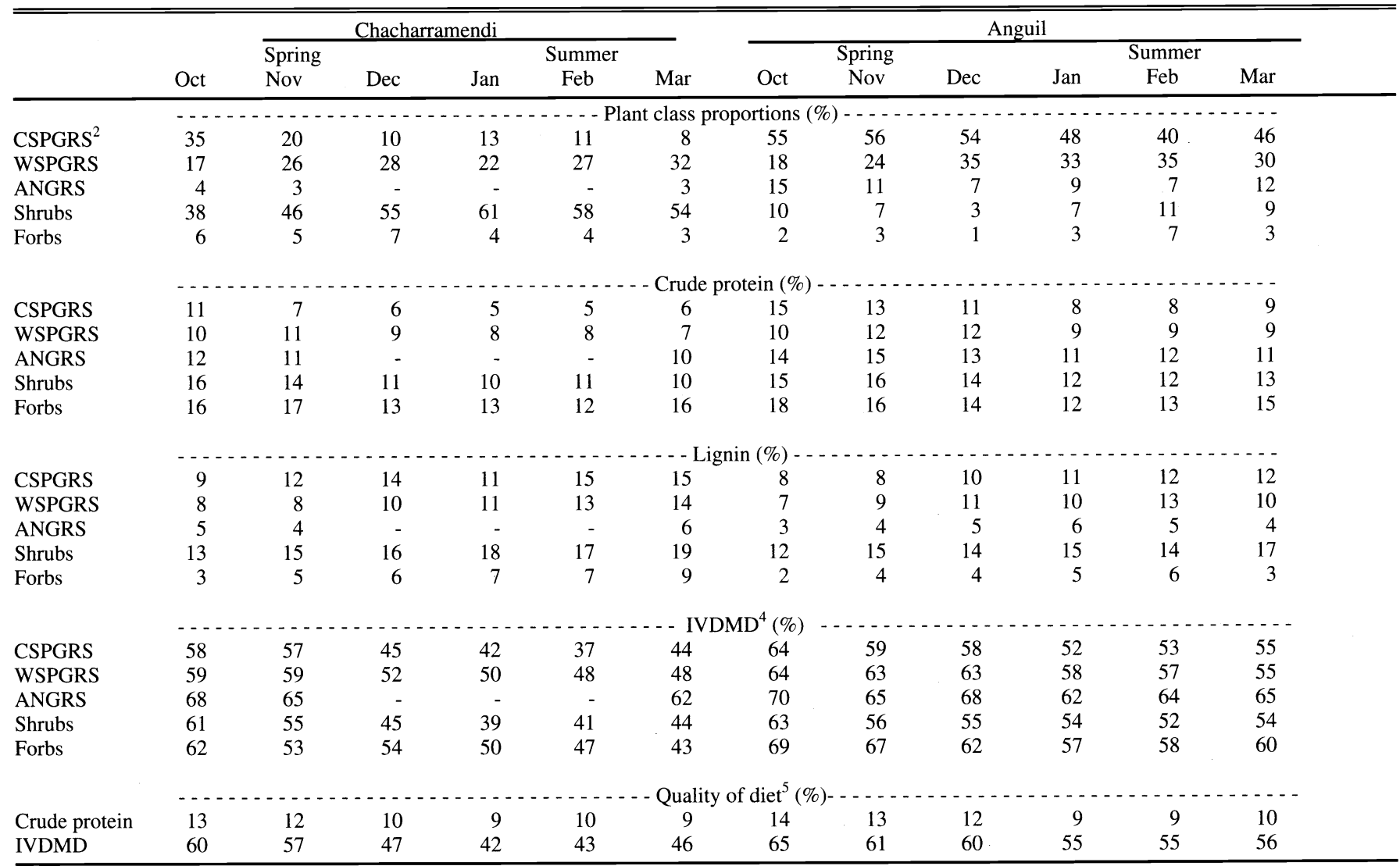

Estimated by microhistology of fecal samples

${ }^{2}$ CSPGRS = Cool-season perennial grasses; WSPGRS = Warm-season perennial grasses; ANGRS = Annual grasses

${ }_{4}^{3}$ Kjeldahl N x 6.25

${ }^{4}$ In vitro dry matter digestibility

${ }^{5}$ Calculated from class proportion and quality data

\section{Experiment 2}

Available biomass in alfalfa pastures was greater than $2200 \mathrm{~kg} \mathrm{DM} \mathrm{ha}{ }^{-1}$ throughout the 148-day study period and calf intake should not have been restricted. Table 2 shows nutrient composition of feeds and forage used in the study. The normally-weaned calves were heaviest $(P$ $<0.01$ ) at the end of trial, compared with early-weaned ones, within age groups (Table 7), and differences increased as age at weaning decreased. Calves from the normal weaning treatment were 15 and 13 $\mathrm{kg}$ heavier in the oldest group (AGE1), 18 and $15 \mathrm{~kg}$ in the intermediate (AGE2), and 31 and $23 \mathrm{~kg}$ in the youngest (AGE3), compared with the 15-day supplemented and 45-day supplemented early-weaned calves, respectively. Within the normal weaning treatment, a decrease in ADG with decreasing age was detected $(\mathrm{P}<$ 0.05 ) in period 1 (Table 8). Gains, however, did not differ $(P>0.28)$ between age groups in periods 2 and 3 . Despite the cited initial effect, ADG of all age groups of normally-weaned calves did not differ
$(\mathrm{P}>0.43)$ over the pre-weaning period (accumulated periods 1, 2, and 3).

Before normal weaning time, ADG was usually greater $(P<0.01)$ in normallyweaned calves compared to early-weaned calves, within each period and age group (Table 8). Differences became larger as days progressed and early-weaned calves were deprived of supplemental feed (periods 1, 2, and 3). During the 30-day period after weaning (period 4), normally-weaned calves showed lower $(\mathrm{P}<0.01)$ ADG, compared with the previous period. In this period, the youngest group of normallyweaned calves had lower $(\mathrm{P}<0.05)$ ADG than the oldest and the intermediate age group, possibly showing a detrimental effect of weaning 162-day old calves onto a $100 \%$ pasture diet. Average daily gain of normally-weaned calves within age group in period 4 did not differ $(P>0.28)$ from gain of 15-day supplemented and 45-day supplemented early-weaned calves.

Thirty days later (period 5), normallyweaned calves showed increased $(\mathrm{P}<$ 0.05) ADG compared with earlier periods.
Moreover, the youngest group had greater $(\mathrm{P}<0.05)$ ADG, compared with the other 2 , and the greatest ADG of the study, likely expressing compensatory growth. Likewise, ADG of these calves was greater $(\mathrm{P}<0.01)$ than ADG of earlyweaned calves within all age groups in this period. Over the study, no differences $(\mathrm{P}=$ 0.58 ) in ADG were detected between age groups for normally-weaned calves.

Age at early weaning date (day 0 of trial) correlated highly with body weight ( $\mathrm{r}$ $=0.97$ ). The youngest calves were 16 days younger and $15 \mathrm{~kg}$ lighter than those in the intermediate group. In turn, the intermediate group was 18 days younger and $20 \mathrm{~kg}$ lighter than the oldest. Body weight differences among age groups noted at early weaning time remained significant $(\mathrm{P}<$ 0.05 ) for each sampling period and across the study. Within the supplementation treatments of early-weaned calves, the heaviest calves at early weaning time were also the heaviest at the end of trial $(\mathrm{P}<$ $0.05)$. The shortest supplementation period magnified ADG differences due to age. 
Table 7. Weight of Angus calves early weaned (EW) at 3 different ages and supplemented on pasture for 15 (S15) or 45 (S45) days, compared with weight of calves of corresponding ages at early weaning time and normally weaned $(\mathrm{NW})^{1,2}$.

\begin{tabular}{|c|c|c|c|c|c|}
\hline \multirow{2}{*}{$\begin{array}{l}\text { Age at } \\
\text { early weaning }\end{array}$} & \multirow{2}{*}{$\begin{array}{c}\text { Days of } \\
\text { trial }\end{array}$} & \multicolumn{2}{|c|}{ EW calves } & \multicolumn{2}{|c|}{ NW calves } \\
\hline & & $\overline{\mathrm{S} 15}$ & S45 & & $\mathrm{SE}^{4}$ \\
\hline & & A & ion of th & ys) - - - & $\ldots$ \\
\hline AGE1 & 0 & 108 & 110 & 110 & 2.4 \\
\hline AGE2 & 0 & 92 & 91 & 91 & 1.0 \\
\hline AGE3 & 0 & 78 & 73 & 75 & 3.1 \\
\hline $\mathrm{SE}^{5}$ & & 1.8 & 3.1 & 1.9 & \\
\hline & & - & Neight* & & - - \\
\hline AGE1 & 0 & 115 & 114 & 114 & 2.0 \\
\hline AGE2 & 0 & 94 & 94 & 94 & 1.7 \\
\hline AGE3 & 0 & 79 & 80 & 79 & 1.4 \\
\hline SE & & 1.8 & 2.0 & 1.3 & \\
\hline AGE1 & 27 & 132 & 131 & 132 & 2.2 \\
\hline AGE2 & 27 & 110 & 110 & 111 & 1.7 \\
\hline AGE3 & 27 & 94 & 95 & 96 & 1.5 \\
\hline SE & & 1.8 & 2.2 & 1.3 & \\
\hline AGE1 & 57 & $147^{\mathrm{a}}$ & $150^{\mathrm{ab}}$ & $152^{\mathrm{b}}$ & 2.3 \\
\hline AGE2 & 57 & $123^{\mathrm{a}}$ & $128^{\mathrm{b}}$ & $131^{\mathrm{b}}$ & 1.7 \\
\hline AGE3 & 57 & $104^{\mathrm{a}}$ & $112^{\mathrm{b}}$ & $117^{\mathrm{c}}$ & 1.5 \\
\hline SE & & 1.8 & 2.3 & 1.2 & \\
\hline AGE1 & 87 & $162^{\mathrm{a}}$ & $164 a$ & $172^{\mathrm{b}}$ & 2.4 \\
\hline AGE2 & 87 & $137^{\mathrm{a}}$ & $141 \mathrm{a}$ & $151^{\mathrm{b}}$ & 1.8 \\
\hline AGE3 & 87 & $116^{\mathrm{a}}$ & $124 b$ & $136^{\mathrm{c}}$ & 1.7 \\
\hline SE & & 1.8 & 2.4 & 1.3 & \\
\hline AGE1 & 117 & $178^{\mathrm{a}}$ & $180^{\mathrm{a}}$ & $187^{b}$ & 2.5 \\
\hline AGE2 & 117 & $153^{\mathrm{a}}$ & $157^{\mathrm{a}}$ & $167^{b}$ & 1.9 \\
\hline AGE3 & 117 & $129^{\mathrm{a}}$ & $137^{\mathrm{b}}$ & $150 \mathrm{c}$ & 2.6 \\
\hline SE & & 2.0 & 2.6 & 1.6 & \\
\hline AGE1 & 148 & $194^{\mathrm{a}}$ & $196^{\mathrm{a}}$ & $209^{\mathrm{b}}$ & 2.6 \\
\hline AGE2 & 148 & $170^{\mathrm{a}}$ & $173^{\mathrm{a}}$ & $188^{\mathrm{b}}$ & 1.8 \\
\hline AGE3 & 148 & $143^{\mathrm{a}}$ & $151^{\mathrm{b}}$ & $174^{\mathrm{c}}$ & 2.6 \\
\hline SE & & 2.2 & 2.8 & 1.8 & \\
\hline
\end{tabular}

Calves of the NW treatment were kept with the dams until day 87 of trial; NW calves reached the ages 196, 178, and 162 days, for AGE1, AGE2 and AGE3, respectively.

${ }^{2} \mathrm{~A}$ weaning treatment $\mathrm{x}$ age group $\mathrm{x}$ period interaction was detected $(\mathrm{P}<0.001)$; therefore, interaction means are reported.

${ }^{3}$ Age groups at early weaning date: AGE1 $=111 \pm 2.2$ days of age; AGE2 $=91 \pm 1.6$ days of age, and AGE3 $=75 \pm 3.8$ days of age.

${ }^{4} \mathrm{SE}=$ Standard error for diet effect.

${ }^{5} \mathrm{SE}=$ Standard error for age group effect.

*Weight differences between age groups within period and diet treatment are all significant $(\mathrm{P}<0.05)$

${ }^{a b c}$ Means in rows with different superscripts differ $(\mathrm{P}<0.05)$.

Feeding supplement for only 15 days detrimentally affected the youngest group at early weaning. After 148 days, the 15day and 45-day supplemented calves from the oldest early-weaned group (AGE1) were 23 and $24 \mathrm{~kg}$ heavier $(\mathrm{P}<0.05)$ than calves from corresponding groups of the intermediate age at early weaning (AGE2). No supplementation effect was detected $(\mathrm{P}>0.34)$ within these 2 age groups. Differences, however, between the oldest (AGE1) and youngest (AGE3) calves were greater $(\mathrm{P}<0.05)$ in the 15 day than in the 45-day supplementation treatment (52 and $45 \mathrm{~kg}$, respectively).

Body weight and ADG did not differ ( $P$ $>0.26$ ) between supplementation treatments imposed on early-weaned calves within each age group for period 1. For earlyweaned calves, period 1 consisted of 12 days on pen-fed diet plus 15 days on pasture with supplemental feed. Differences in
ADG were not expected because diets were the same for all early-weaned calves during the pen feeding period and the first 15 days on pasture. After day 15 on pasture, early-weaned calves of the 15-day supplementation treatment received no supplemental feed. During the following period, (period 2) all age groups of this treatment (S15 calves) showed lower $(\mathrm{P}<0.05)$ ADG compared with period 1. Group AGE3 3 S15 reached the lowest rate of gain of this trial in this period. The switch of diet to $100 \%$ forage may explain this effect. During the same period, 45-day supplemented early-weaned calves (S45) maintained similar ( $\mathrm{P}>0.25$ ) ADG to period 1. This response would be expected because diet did not change in this treatment. Consequently, ADG of 15-day supplemented early-weaned calves were lower $(\mathrm{P}<0.05)$ than gains of 45 -day supplemented early-weaned calves. Body weight differences, however, between supplementation treatments were not detected yet $(\mathrm{P}>0.34)$ for the oldest calves. Forty five-day supplemented early-weaned calves were 5 and $8 \mathrm{~kg}$ heavier $(\mathrm{P}<0.05)$ than 15-day supplemented early-weaned calves in the intermediate and youngest groups, respectively (Table 7).

After 30 days on forage diet (period 3), the oldest and intermediate age groups of 15-day supplemented early-weaned calves maintained $(\mathrm{P}>0.24)$ ADG compared with period 2. The youngest group (AGE3) increased $(\mathrm{P}<0.05)$ ADG during this period. In the same period, supplemental feeding of calves in the 45-day supplementation treatment (S45) was stopped, and ADG of this treatment decreased $(\mathrm{P}<0.05)$ compared with period 2. The switch of diets may have been the main factor responsible for this ADG depression. During this period, ADG of 15-day supplemented early-weaned calves from the oldest and intermediate age groups were greater $(\mathrm{P}<0.05)$ than ADG of 45-day supplemented calves (Table 8). On day 87 , body weights for calves from the 15 and 45-day supplementation treatments within the oldest and the intermediate age groups, did not differ $(\mathrm{P}>0.17)$, but weights between supplementation treatments were different $(\mathrm{P}<0.05)$ for the youngest group.

In period 4, ADG of 45-day supplemented early-weaned calves of all age groups and 15-day supplemented earlyweaned calves from the intermediate and the youngest groups increased $(\mathrm{P}<0.05)$, compared to gains achieved in period 3 . Both supplementation treatments (S15 and $\mathrm{S} 45)$ had similar $(\mathrm{P}>0.15)$ ADG within age groups during this period. Similarly, a month later (period 5) no differences were detected $(P>0.43)$ between supplementation treatments of early-weaned calves within age group. Over the 148-day period, no differences in $\mathrm{BW}$ were detected ( $\mathrm{P}$ $>0.22$ ) between supplementation treatments for the oldest and the intermediate age groups (Table 7). Differences, however, were evident in the youngest group ( $P$ $<0.01)$.

Overall ADG increased $(\mathrm{P}<0.05)$ with weaning age within the 15-day supplementation treatment for early-weaned calves. A similar trend was noted for the 45-day supplementation treatment, although no differences in overall ADG were detected $(\mathrm{P}=0.16)$ between the oldest and the intermediate (111 and 91 days of age at weaning) groups in this treatment. Gain increased $(\mathrm{P}<0.05)$ also with length of supplementation period within 
Table 8. Average daily gain (ADG, $g$ animal ${ }^{-1}$ ) of Angus calves early weaned (EW) at 3 different ages and supplemented on pasture for 15 (S15) or 45 (S45) days, compared with ADG of calves normally weaned $(\mathrm{NW})^{1,2}$.

\begin{tabular}{|c|c|c|c|c|}
\hline \multirow{2}{*}{$\begin{array}{l}\text { Age at } \\
\text { early weaning }\end{array}$} & \multicolumn{2}{|c|}{ EW calves } & \multicolumn{2}{|c|}{ NW calves } \\
\hline & $\overline{S 15}$ & $\mathrm{~S} 45$ & & $\mathrm{SE}^{4}$ \\
\hline & \multirow{2}{*}{\multicolumn{4}{|c|}{$\left(\mathrm{g}\right.$ animal $\left.^{-1}\right)$}} \\
\hline & & & & 07 \\
\hline AGE1 & $647^{\mathrm{aA} \psi}$ & $641^{\mathrm{aA} \psi}$ & $643^{\mathrm{aA} \psi}$ & 9.7 \\
\hline AGE2 & $590^{\mathrm{aB} \psi}$ & $597^{\mathrm{aB} \psi}$ & $626^{\mathrm{bAB} \psi}$ & 7.7 \\
\hline AGE3 & $552^{\mathrm{aC} \psi}$ & $550^{\mathrm{aC} \psi}$ & $609^{\mathrm{bB} \psi}$ & 11.1 \\
\hline $\mathrm{SE}^{5}$ & 10.3 & 9.9 & 8.5 & . \\
\hline AGE1 & $485^{\mathrm{aA \theta}}$ & $638^{\mathrm{bA} \psi}$ & $681^{\mathrm{cA \theta \gamma}}$ & 11.1 \\
\hline AGE2 & $449^{\mathrm{aB} \theta}$ & $594^{\mathrm{bB} \psi}$ & $678^{\mathrm{cA \theta} \gamma}$ & 8.3 \\
\hline AGE3 & $352^{\mathrm{aC} \theta}$ & $552^{\mathrm{bC} \psi}$ & $697^{\mathrm{cAq}}$ & 11.1 \\
\hline $\mathrm{SE}$ & 6.9 & 8.1 & 14.5 & \\
\hline AGEl & $526^{\mathrm{a} A \theta \lambda}$ & $458^{\mathrm{bA \theta}}$ & $661^{\mathrm{cA} \psi \theta}$ & 11.5 \\
\hline AGE2 & $463^{\mathrm{aB} \theta}$ & $441^{\mathrm{bA \theta}}$ & $659^{\mathrm{cA} \theta}$ & 7.1 \\
\hline AGE3 & $398^{\mathrm{aC} \lambda}$ & $404^{\mathrm{aB} \theta}$ & $653^{\mathrm{bA} \theta}$ & 9.3 \\
\hline $\mathrm{SE}$ & 11.2 & 6.6 & 10.1 & \\
\hline AGE1 & $520^{\mathrm{aA} \lambda}$ & $517^{\mathrm{aA} \lambda}$ & $516^{\mathrm{aA} \lambda}$ & 10.1 \\
\hline AGE2 & $524^{\mathrm{aA} \lambda}$ & $517^{\mathrm{aA} \lambda}$ & $510^{\mathrm{aA} \lambda}$ & 8.1 \\
\hline AGE3 & $431^{\mathrm{aB} \gamma}$ & $453^{\mathrm{aB} \lambda}$ & $448^{\mathrm{aB} \lambda}$ & 20.7 \\
\hline $\mathrm{SE}$ & 10.5 & 11.6 & 18.9 & \\
\hline AGE1 & $532^{\mathrm{aA} \lambda}$ & $541 \mathrm{aA} \lambda$ & $693^{\mathrm{bA \gamma}}$ & 10.0 \\
\hline AGE2 & $535^{\mathrm{aA} \lambda}$ & 529 aA $\lambda$ & $699^{\mathrm{bA \gamma}}$ & 13.2 \\
\hline AGE3 & $440^{\mathrm{aB} \gamma}$ & $444 \mathrm{aB} \lambda \theta$ & $777^{\mathrm{bB} \gamma}$ & 18.6 \\
\hline SE & 13.1 & 19.9 & 7.5 & \\
\hline AGE1 & $540^{\mathrm{aA}}$ & $557^{\mathrm{bA}}$ & $639^{\mathrm{cA}}$ & 5.1 \\
\hline AGE2 & $511^{\mathrm{aB}}$ & $534^{\mathrm{bA}}$ & $635^{\mathrm{cA}}$ & 5.6 \\
\hline AGE3 & $432^{\mathrm{aC}}$ & $479^{\mathrm{bB}}$ & $638^{\mathrm{cA}}$ & 9.5 \\
\hline \multirow[t]{2}{*}{$\mathrm{SE}$} & 6.7 & 8.7 & 6.5 & \\
\hline & $\ldots$ & SE for perio & isons $^{7}$ - & - \\
\hline AGE1 & 12.5 & 14.0 & 17.7 & \\
\hline AGE2 & 6.8 & 11.9 & 8.0 & \\
\hline AGE3 & 11.6 & 10.3 & 9.8 & \\
\hline
\end{tabular}

Calves of the NW treatment were kept with the dams until day 87 of trial. Normally weaned calves were 196,178 , and 162 days of age for groups AGE1, AGE2 and AGE3, respectively, at weaning.

${ }_{3}^{2} \mathrm{~A}$ weaning treatment $\mathrm{x}$ age group $\mathrm{x}$ period interaction was detected $(\mathrm{P}<0.001)$; therefore, interactive means are reported.

${ }^{3}$ Age groups at early-weaning date (day 0 of trial): AGE1 $=111 \pm 2.2$ days of age; AGE2 $=91 \pm 1.6$ days of age, and $\mathrm{AGE} 3=75 \pm 3.8$ days of age.

${ }_{5}^{4} \mathrm{SE}=$ Standard error for diet effect.

${ }^{5} \mathrm{SE}=$ Standard error for age group effect.

${ }^{6}$ Period $1=$ ADG between day 0 and 27 of trial, Period $2=$ between day 27 and 57; Period $3=$ between day 57 and 87 ; Period $4=$ between day 87 and 117 ; Period $5=$ between day 117 and 148 .

${ }^{7} \mathrm{SE}=$ Standard error for period effect within age group and diet.

${ }^{a b c}$ Row means with different lowercase superscripts differ $(\mathrm{P}<0.05)$.

${ }^{A B C}$ Column means within period with different uppercase superscripts differ $(\mathrm{P}<0.05)$.

${ }^{\text {yqlg }}$ Column means within age group across periods with different superscripts differ $(\mathrm{P}<0.05)$.

and across weaning ages. Within early weaning treatments, calves weaned at the youngest age ( 75 days of age) were the group most affected by the diets imposed, and those in this age group receiving supplement for only 15 days experienced the lowest overall rate of growth.

Reports on compared performance of early-weaned calves exposed to limited supplementation programs are scarce. Early weaning on a $100 \%$ forage diet compared to a $1.1 \mathrm{~kg} \mathrm{day}^{-1}$ animal $^{-1}$ of supplemental feed was reported by Simeone et al. (1997). Supplemented early-weaned calves gained $310 \mathrm{~g} \mathrm{day}^{-1}$ more than nonsupplemented ones. most affected under feeding programs that use a supplementation period on pasture shorter than 45 days.

Shortening of supplementation period on pasture to 15 days after weaning can have negative effects on performance. The effect, however, would be less dramatic if calves are 90-day old or older at weaning time. If calves are younger, supplementation during at least 45 days may be necessary to achieve an acceptable rate of growth. More research is needed to develop improved options that combine adequate calf growth and reduced costs without compromising future calf performance. Questions such as calf age and weight, forage quality, and supplement level interactions remain to be addressed in future research on early weaning.

\section{Literature Cited}

AOAC. 1990. Official methods of Analysis (15 $5^{\text {th }}$ Ed.). Assoc. of Official Analytical Chem., Washington, DC.

Fernández, G.D. and A.E. Zúcari. 1996. Efecto del destete precoz sobre la performance reproductiva en vaquillonas de primera parición. Rev. Arg. Prod. Anim. 16(1):49.

Fernández, G.D., A.E. Zúcari, and E.L. Antón. 1997. Efecto de la edad del destete sobre la performance de vacas de refugo y ternero. Rev. Arg. Prod. Anim. 17(1):279.

Fluharty, F.L., S.C. Loerch, T.B. Turner, S.J. Moeller, and G.D. Lowe. 2000. Effects of weaning age and diet on growth and carcass characteristics in steers. J. Anim. Sci. 78:1759-1767.

Gill, D.R., F. N. Owens, M.C. King, and H.G. Dolezal. 1993. Body composition of grazing or feedlot steers differing in age and background. Okla. Agr. Exp. Sta. Res. Rep. pp. 993:185-190.

Goering, H.K. and P.J. Van Soest. 1970. Forage fiber analyses (apparatus, reagents, procedures, and some applications). Agr. Handb. 379. ARS, USDA, Washington, D.C.

Hidalgo, L.G., S. Callejas, M.A. Cauhepé, and M.J. Otero. 1996. Efecto del destete precoz sobre la condición corporal y la preñez en vacas multíparas. Rev. Arg. Prod. Anim. 16(1):36.

Our study provides evidence that early weaning at 2 to 3 months of age, with proper feeding, is a feasible technique to reduce herd requirements without affecting calf performance. Moreover, in cases of feed restrictions for the cows and calves, it could favor not only the cow, but also the calf.

Low-cost feeding programs can successfully be implemented, however, calf requirements should not be underestimated. Results from this study indicate that 70 to 80 day-old weaned calves would be the
Hofer, C.C., J.J. Bruno, and A.R. Monje. 1984. Comportamiento de terneros destetados a los 60 días de edad. Manejo del destete y método de crianza. EEA INTA C. Del Uruguay. Prod. Anim. Inf. Téc. 1:126-132.

Holechek, J.L. and B.D. Gross. 1982. Evaluation of diet selection in ruminants. Functional Ecol. 2:15-22.

Holechek, J.L., M. Vavra, and R. D. Pieper. 1982. Botanical determination of range herbivore diets: a review. J. Range Manage. 35:309-315. 
Kugler, N.M., H. Giorgetti, G. Cecchi, G. Rodriguez, y O. Montenegro. 1997a. Módulos de cría: Destete precoz vs convencional. Jornadas de cría en campos de monte. EEA Valle Inferior de Río Negro, IDEVIINTA p. 52-53.

Kugler, N.M., H. Giorgetti, G. Cecchi, G. Rodriguez, y O. Montenegro. 1997b. Destete precoz e incremento en la carga animal. 1. Efecto sobre los vientres. Rev. Arg. Prod. Anim. 17(1):269.

Laster, D.B., H.A. Climp, and K.E. Gregory. 1973. Effects of early weaning on paspartum reproduction of cows. J. Anim. Sci. 36:734-740.

Lusby, K.S. and A.A. Parra. 1981. Effects of early weaning on calf performance and on reproduction in mature cows. Okla. Agr. Exp. Sta. Rep. MP 108:64-68.

Lusby, K.S. and R.P. Wettemann. 1980. Effects of early weaning calves from first calf heifers on calf and heifer performance. Okla. Agr. Exp. Sta. Res. Rep. MP 107:55-58.

Lusby, K.S., R.P. Wettemann, and E.J. Turman. 1981. Effects of early weaning calves from first-calf heifers on calf and heifer performance. J. Anim. Sci. 53:11931197.

Lusby, K.S., D.R. Gill, D.M. Anderson, T.L Gardner, and H.G. Dolezal. 1990. Limit feeding vs full feeding high concentrate diets to early-weaned calves- effects on performance to slaughter. Okla. Agr. Exp. Sta. Res. Rep. MP 129:128-134.
Monje, A.R., C.C. Hofer, and I.O. Galli. 1978. Destete precoz y creep-feeding. Efecto sobre la receptividad. AAPA Prod. Anim. 6:391-396.

Monje, A.R., C.C. Hofer, and I.O. Galli. 1993. Destete precoz: Efecto sobre los vientres, manejo de los terneros e impacto de la técnica sobre los sistemas de producción. Memorias. Jornada de difusión técnica: Destete precoz en cría vacuna. EEA INTA C. Del Uruguay. pp.13-38.

Myers, S.E., D.B. Faulkner, F.A. Ireland, and, D.F. Parrett. 1999a. Comparison of three weaning ages on cow-calf performance and steer carcass traits. J. Anim. Sci. 77:323-329.

Myers, S.E., D.B. Faulkner, F.A. Ireland, L.L. Berger, and D.F. Parrett. 1999b. Production systems comparing early weaning to normal weaning with or without creep feeding for beef steers. J. Anim. Sci. 77:300-310.

National Research Council. 1996. Nutrient requirements of beef cattle. Seventh Revised Ed. Washington D.C.: National Academy Press.

Peterson, O.W., T.B. Turner, K.M. Irvin, M. E. Davis, H. W. Newland, and W. R. Harvey. 1987. Cow and calf performance and economic considerations of early weaning of fall-born beef calves. J. Anim. Sci. 64:15-22.
Roberto, Z.E., G. Casagrande, and E.F Viglizzo, 1996. Lluvias en la pampa central. Tendencias y variaciones del siglo. Cambio climático y agricultura sustentable en la región pampeana. Ed. INTA PEI 2:3-25.

Robertson, J.B. and P.J. Van Soest. 1981. The detergent system analysis and its applications to human foods: $I n$ : W.P.T. James and O. Theander (Ed.) The Analysis of Dietary Fiber. pp 123-158. Marcell Dekker, New York.

SAS. 1991. Statistics Analysis System User's Guide. SAS Institute Inc. Cary. N.C.

Sciotti, A.E., J. Carrillo, L.M. Melucci and A. Cano. 1996. Efecto del destete precoz en vacas primíparas y de última parición sobre los pesos y ganancias de peso de los terneros y sus madres. Rev. Arg. Prod. Anim. 16(1):30.

Simeone, A., A.I. Trujillo, G. Córdoba, J. Gil, M. Rodríguez, A. Bejerez, R. Zanoniani, F. Baccino, and M. Umpierrez. 1997. Efecto del destete precoz y de dos sistemas de alimentación post-destete sobre la ganancia de peso de terneros Hereford hasta los 15 meses de edad. Rev. Arg. Prod. Anim. 17(1):58.

Sparks, D.R. And J.C. Malechek. 1968. Estimating percentage dry weight in diets using a microscopic technique. J. Range Manage. 21:264-265.

Tilley, J.M.A. and R.A. Terry. 1963. A twostage technique for in vitro digestion of forage crops. J. Brit. Grassl. Soc. 18:104. 


\title{
Density and reproductive success of Florida grasshopper sparrows following fire
}

\author{
MICHAEL F. DELANY, STEPHEN B. LINDA, BILL PRANTY, AND DUSTIN W. PERKINS
}

Authors are Wildlife Biologist and Biometrician, Florida Fish and Wildlife Conservation Commission, Wildlife Research Laboratory, Gainesville Fla. 32601; Avian Project Leader, Audubon of Florida, Tampa, Fla. 33619; and Ph.D. candidate, University of Maine, Orono, Me. 04684.

\begin{abstract}
Information on the response of the endangered Florida grasshopper sparrow (Ammodramus savannarum floridanus Mearns) to range management, especially prescribed fire, is needed to determine conservation strategies. Intensive management of grasslands for cattle grazing and conversion of grassland to other agricultural use is considered the greatest threat to the sparrow. Territory spot-mapping and estimates of reproductive success were examined in relation to time post-burn in managed cattle pastures at Avon Park Air Force Range, Highlands County, Florida from 1997-1999. We tested the hypothesis that sparrow density and reproductive success did not depend on time following fire. Contrary to previous work, there was no evidence that Florida grasshopper sparrow territory density depended on years post-burn $(P=0.842)$. The probability of reproductive success was significantly higher 0.5 year post-burn than at 1.5 years post-burn $(P<0.05)$ and 2.5 years post-burn $(P<0.01)$. No other significant differences were observed among years post-burn (P $>0.27$ for each pairwise comparison between years). No simple trend or highly significant polynomial relationship between reproductive success and territory density was indicated $(P>$ 0.41). Compared to other subspecies, Florida grasshopper sparrows exhibited relatively low density $(0.22$ territories/ha or less) and reproductive success $(20 \%)$. Our results suggest increased reproductive success at a population level 0.5 year following fire, and did not suggest an association between territory density and individual reproductive success. Additional information is needed on the effects of seasonality of fire on Florida grasshopper sparrows.
\end{abstract}

Key Words: Ammodramus savannarum floridanus, Florida prairie, prescribed fire

Declines in the abundance of some grassland birds in North America are attributed to habitat loss induced by changes in land management (Peterjohn and Sauer 1999). Grasshopper sparrows (Ammodramus savannarum Gmelin) are locally distributed in low to medium height grasslands throughout most of temperate North America, from Mexico to Ecuador, and the West Indies. Breeding bird surveys evince a decline in some populations (Vickery 1996). The Florida subspecies (A. s. floridanus Mearns) is endemic to the

This study was supported by Cooperative Agreement No. 14-45-0009-154 Research work order 175, funded by the U.S. Air Force through the Florida Cooperative Fish and Wildlife Research Unit.

Manuscript accepted 24 Oct 01.

\section{Resumen}

Se necesita información de la respuesta de la especie en peligro de extinción "Florida grasshopper sparrow" (Ammodramus savannarum floridanus Mearns) al manejo del pastizal, especialmente al fuego prescrito, para determinar estrategias de conservación. El manejo intensivo de los pastizales para apacentamiento de ganado y la conversión del pastizal a otros usos agrícolas se consideran como la mayor amenaza para el "Sparrow". De 1997 a 1999 el mapeo de manchas territoriales y estimaciones de éxito reproductivo se examinaron en relación al tiempo después de la quema, lo cual se realizó en potreros manejados para ganado en la Base Aérea Avon Park, en el condado Highlands, Florida. Probamos la hipótesis de que la densidad de "Sparrow" y el éxito reproductivo no depende del tiempo después de la quema. Contrario a trabajos previos, no hubo evidencia de que la densidad territorial del "Florida grasshopper sparrow" dependa de los años después de la quema $(P=0.842)$. La probabilidad de éxito reproductivo fue significativamente mayor 0.5 años que 1.5 años después de la quema $(P<0.05)$ y que 2.5 años después del fuego $(P<0.01)$. No se observaron otras diferencias significativas entre años después de la quema $(P>0.27$ para cada comparación de pares entre años). No se detectó $(P>0.41)$ una tendencia simple o una tendencia polinomial altamente significativa entre el éxito reproductivo y la densidad territorial. Comparado con otras subespecies, el "Florida grasshopper sparrows"mostró una densidad territorial relativamente baja $(0.22$ territorios/ha o menos) y un bajo éxito reproductivo (20\%). Nuestros resultados sugieren un mayor éxito reproductivo, a nivel de población, 0.5 años después del fuego y no sugieren una asociación entre la densidad territorial y el éxito reproductivo individual. Se necesita información adicional sobre los efectos de la estacionalidad del fuego en el "Florida grasshopper sparrows".

south-central, dry prairie region of the state and was classified as endangered because of its restricted distribution, loss of habitat, and population decline (U.S. Fish and Wildlife Service 1988). Breeding aggregations are known from only 6 locations and fewer than 1,000 birds may exist (Delany et al. 1999). Information on the sparrow's response to range management is needed before conservation strategies for the subspecies can be fully assessed (U.S. Fish and Wildlife Service 1988).

An examination of structural characteristics of occupied and abandoned territories indicated that Florida grasshopper sparrows cannot adapt to habitat perturbations that remove potential nest sites (bunch grasses and dwarfed shrubs) and bare-ground foraging areas (Delany and Linda 1994). Intensive management of 
grasslands for cattle grazing and conversion of grassland to other agricultural use is the greatest threat to the sparrow (U.S. Fish and Wildlife Service 1988). Improved pastures are created and maintained by mechanical clearing and planting bahia grass (Paspalum sp.), pangola grass (Digitaria sp.), American joint vetch (Aeshynomene americanus L.), and clover (Trifolium spp.) (Milleson et al. 1980, Delany and Linda 1994). Prairies also are plowed and planted with bahia grass for sod production. Shriver and Vickery (1999) estimated only $19 \%$ (156,000 ha) of the original dry prairie remained in central peninsular Florida.

The Florida grasshopper sparrow has benefitted from prescribed burning at some locations. Prescribed fire at 2-3 year intervals during the winter dormant season (December-March) is the most common practice used to improve prairie pastures for cattle grazing in Florida (Lewis 1964, Abrahamson and Hartnett 1990). Frequent burning also maintains vegetation in a sparse, early successional stage preferred by the sparrow (Delany et al. 1985). Increased densities of Florida grasshopper sparrows associated with time post-burn (Walsh et al. 1995) may be related to changes in prairie physiognomy following fire and have important management implications. However, population density estimates without demographic data may not be a reliable indicator of habitat quality (Van Horne 1983). We examined the density and reproductive success of Florida grasshopper sparrows in relation to time post-burn to assess the effects of prescribed burning, and tested the hypothesis that territory density and reproductive success did not depend on time following fire.

\section{Study Area}

The study area was a 700-ha prairie $\left(27^{\circ} 38.08^{\prime} \mathrm{N}, 81^{\circ} 19.30^{\prime} \mathrm{W}\right)$ on the U.S. Air Force Avon Park Range in Highlands County, Fla. The climate is humid subtropical (Chen and Gerber 1990). Mean annual temperature is $22^{\circ} \mathrm{C}$ with monthly mean temperatures ranging from $17^{\circ} \mathrm{C}$ in January to $28^{\circ} \mathrm{C}$ in August. Mean annual rainfall is $1,370 \mathrm{~mm}$, with most $(60 \%)$ precipitation associated with convective thunderstorms and tropical systems occurring from June to September (Carter et al. 1989). The topography is nearly level and the sandy soils (Malabar and Oldsmar series) are poorly drained (Carter et al. 1989). The grassland was dominated by wiregrass (Aristida beyrichiana Trin. and
Rupr.), bluestems (Andropogon spp.), yellow-eyed grass (Xyris spp.), saw palmetto (Serenoa repens W. Bartram, Small), dwarf live-oak (Quercus minima Sarg.), and shrubs; and included scattered cypress (Taxodium sp.) domes and small (4 ha or less) hypericum (Hypericum spp.) ponds. The study area was bordered by slash pine (Pinus elliottii Engelm.) plantations, opencanopy longleaf pine (P. palustris Mill.), introduced pastures (plowed and planted with non-native grasses), and freshwater marsh. Cattle grazed the study area at 1 animal per 8.7-28.3 ha with grazing periods of 21 days or less followed by longer periods of exclusion. Forage utilization during a grazing period was light. Four prairie pastures (165-324 ha) were burned with head fires (burned with the wind) on 3-year rotations between December and mid-March to enhance forage production and manage habitat for Florida grasshopper sparrows. Ordnance-ignited wildfires occur year-round.

\section{Methods}

\section{Sparrow Density and Reproductive Success}

The density of Florida grasshopper sparrow territories was determined using standard spot-mapping techniques (International Bird Census Committee 1970) on 12 study plots ( 8.5 to 20.0 ha, $\bar{x}=12.8$ ha) at least $50 \mathrm{~m}$ from non-prairie habitats and separated by at least $100 \mathrm{~m}$. Plots were the same as those used by Shriver and Vickery (2001). Plots were marked with $50 \mathrm{~m}$ grids of labeled wired flags. Spot-mapping periods of about 1 hour per plot were made by walking to each grid marker, with direction alternated between successive sur- veys. Observations of sparrow locations and reproductive success were recorded in reference to the grid markers. Surveys were conducted between sunrise and 1000 hours in the absence of rain and at wind velocities less than $11 \mathrm{~km} /$ hour. Plots were sampled 8-13 times each year at about 10 day intervals from 22 March-25 August, 1997-1999. Based on maximum territory size, male sparrows observed on different days more than $203 \mathrm{~m}$ apart were considered separate individuals (Walsh et al. 1995), and those exhibiting breeding behavior for at least 4 weeks were considered territorial (Vickery et al. 1992a). Locations of male sparrows were digitized and territories mapped with ArcView GIS software (ESRI 1990). Density was considered the number of territories per ha and included only those that were at least $50 \%$ within a plot. A territorial male was deemed to have reproduced successfully if fledglings were observed or adults carrying food for at least 9 days were observed (according to Vickery et al. 1992a). The detectability of sparrows on the ground was probably related to time post-burn and corresponding differences in vegetation density, however, adults carrying food perched on shrubs or fences and were easily observed in any post-burn stage. Time post-burn was recorded for each plot and categorized into $0.5,1.0,1.5$, or 2.5 year classes (Table 1).

\section{Data Analysis}

For territory density, the experimental design was considered to be an incomplete blocks design, in which the blocks were plots and the treatment was years postburn. A search for the Box-Cox variance stabilizing power transformation indicated that the square-root transformation

Table 1. Experimental design used to examine Florida grasshopper sparrow territory density and reproductive success following fire, Avon Park Air Force Range, Highlands County Fla., 1997-1999. The year in which a given years post-burn treatment occurred in a given plot is indicated.

\begin{tabular}{ccccc}
\hline \hline & \multicolumn{5}{c}{ Years post-burn } \\
\cline { 2 - 5 } Plot number & 0.5 & $1.0^{1}$ & 1.5 & 2.5 \\
\hline 1 & 1998 & - & 1997,1999 & - \\
2 & 1999 & - & 1997 & 1998 \\
3 & 1997 & 1999 & 1998 & - \\
4 & 1997 & - & 1998 & 1999 \\
5 & 1997 & - & 1998 & 1999 \\
6 & 1999 & - & 1997 & 1998 \\
7 & 1997 & 1999 & 1998 & 1998 \\
8 & 1999 & - & 1997 & 1999 \\
9 & 1997 & - & 1998 & - \\
10 & 1998 & - & 1997,1999 & - \\
11 & 1997 & 1999 & 1997,1999 & - \\
12 & 1998 & - & 1998 & \\
\hline
\end{tabular}

${ }^{1}$ Burned during an ordnance-ignited wildfire on 29 June 1998. 
induced homoscedasticity. Therefore, it was assumed that the number of territories followed a Poisson distribution, and generalized linear mixed model (GLMM) methodology, as can be implemented in the NLMIXED procedure (SAS Inst., Inc. 1999), was used. The Poisson error distribution and log link were specified for the number of territories per plot, and the offset was specified as the log of plot size.

The GLMM methodology, implemented in PROC NLMIXED in the SAS System (SAS Inst. Inc. 1999), also was used to analyze reproductive success. A logit link and binomial error distribution were specified for the number of territories with successful males for a given plot. Fixed years post-burn effects and random plot-specific effects were included in the linear predictor. If random plot-specific effects appeared negligible, then the simple GLM was fitted in PROC GENMOD (SAS Inst. Inc. 1999). If the global test for years postburn was significant then tests of differences in counts between pairs of years post-burn levels were performed: if random plot effects appeared negligible, then Fishers's exact test was performed for each pair of years post-burn levels.

To graphically examine the possibly nonlinear relationship between reproductive success and territory density, residuals from the analysis of reproductive success were plotted against the residuals from the analysis of density, and a nonparametric smoothed curve (LOESS) was fitted. To statistically test for a relationship between reproductive success and density, hierarchical fixed effects terms for a quintic trend in density were added to the linear predictor in the GLM for reproductive success, and Type 1 hypothesis tests of the fixed effects were performed.

\section{Results and Discussion}

We found no evidence that Florida grasshopper sparrow territory density depended on years post-burn up to 2.5 years $\left(X^{2}=0.830, \mathrm{DF}=3, \mathrm{P}=0.842\right.$ for a Wald test of the years post-burn effect) (Table 2, Fig. 1). Anecdotal accounts indicate higher densities of Florida grasshopper sparrows at recently burned (within 2.5 years) locations (Smith 1968, Delany and Cox 1986). Studies that have quantified habitat selection in relation to time post-burn have found Florida grasshopper sparrow densities ranged from 0.05-0.75 territories/ha during the first year following fire, and decreased to $0.01-0.18$ territories/ha during the subsequent 1.5 years
Table 2. Predicted values of Florida grasshopper sparrow territories per ha at years post-burn (back-transformed scale), Avon Park Air Force Range, Fla., 1997-1999.

\begin{tabular}{|c|c|c|c|c|c|c|c|}
\hline \multirow{2}{*}{$\begin{array}{l}\text { Years } \\
\text { post-burn }\end{array}$} & \multirow[b]{2}{*}{ Mean } & \multirow[b]{2}{*}{$\mathrm{SE}^{1}$} & \multicolumn{2}{|c|}{$95 \%$ CI limits } & \multicolumn{3}{|c|}{$\begin{array}{l}\text { P-value for } \mathrm{H}_{\mathrm{o}} \text { : pair of years-post burn } \\
\text { means are equal }\end{array}$} \\
\hline & & & Lower & Upper & 1.0 & 1.5 & 2.5 \\
\hline$\overline{0.5}$ & 0.20 & 0.050 & 0.113 & 0.344 & 0.77 & 0.59 & 0.50 \\
\hline 1.0 & 0.22 & 0.099 & 0.085 & 0.594 & - & 0.56 & 0.50 \\
\hline 1.5 & 0.17 & 0.043 & 0.099 & 0.300 & - & - & 0.77 \\
\hline 2.5 & 0.16 & 0.053 & 0.074 & 0.330 & - & - & - \\
\hline
\end{tabular}

Obtained by application of the delta method (Seber 1982).
(Walsh et al. 1995, Shriver and Vickery 2001). Walsh et al. (1995) speculated that density changed because young of the year birds dispersed to more suitable, recently burned locations. Increased shrub and saw palmetto growth with the exclusion of fire may eventually allow vegetation to reach a dense successional stage unusable by Florida grasshopper sparrows (Delany et al. 1985). Florida grasshopper sparrow density ( 0.22 territories/ha or less) was lower than most ranges reported for other subspecies (0.21-1.30 territories/ha, in grasslands) (reviewed in Vickery 1996). The sparrow is at the edge of the species' range and may therefore exhibit relatively low abundance (Curnutt et al. 1996).
The plot variance component was negli- gible in the fit of the GLMM for reproductive success $(P=1.00)$. Based on the simple GLM, Florida grasshopper sparrow reproductive success depended on years post-burn $(\mathrm{P}=0.0036)$. The probability of reproductive success was higher 0.5 year post-burn than at 1.5 years post-burn $(\mathrm{P}<$ $0.05)$ and 2.5 years post-burn $(\mathrm{P}<0.01)$. No other pairwise comparisons between years post-burn were significant $(\mathrm{P}>0.27$ for each pairwise comparison) (Table 3, found increased reproductive success for Florida grasshopper sparrows on our study Johnson and Temple (1986) reported higher reproductive success for grasshopper sparrows (A. s. pratensis Vieillot) in recently Fig. 2). Shriver and Vickery (2001) also area in plots 0.5 year following fire.

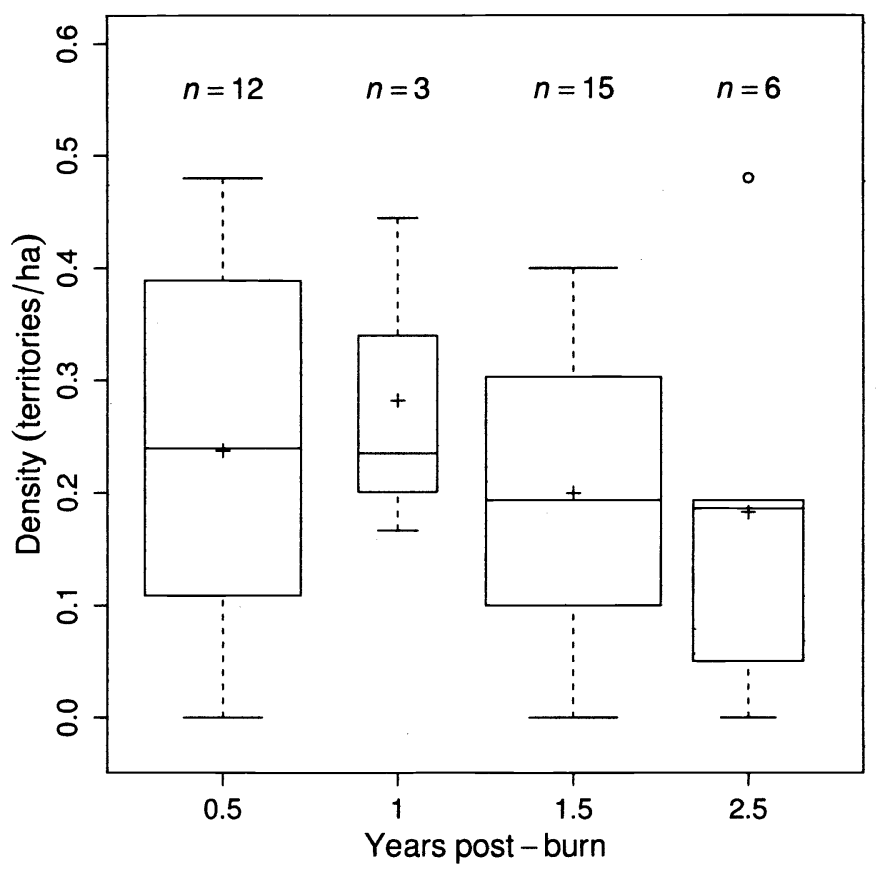

Fig. 1. Boxplots of Florida grasshopper sparrow density ( $n=$ number of plots), Avon Park Air Force Range, Highlands County, Fla., 1997-1999. Study plot and year, and thus possible correlation among observations, were ignored. The bottom and top edges of the box plots are located at the sample $25^{\text {th }}$ and $75^{\text {th }}$ percentiles; the center horizontal line is located at the sample median; the plus symbol is the sample mean; the vertical lines extend to the range of the data, to a distance of at most 1.5 interquartile ranges from the box; and values more extreme than 1.5 interquartile ranges from the box are denoted by circles. Widths of boxes are proportional to the square-root of the number of observations. 
Table 3. Proportion of Florida grasshopper sparrow territories with reproductive success at years post-burn, Avon Park Air Force Range, Fla., 1997-1999.

\begin{tabular}{|c|c|c|c|c|c|c|c|}
\hline \multirow{2}{*}{$\begin{array}{l}\text { Years } \\
\text { post-burn }\end{array}$} & \multirow[b]{2}{*}{$\mathrm{n}$} & \multirow[b]{2}{*}{ Estimate } & \multicolumn{2}{|c|}{$95 \%$ CI limits } & \multicolumn{3}{|c|}{ P-value for pairwise Fisher's exact test } \\
\hline & & & Lower & Upper & 1.0 & 1.5 & 2.5 \\
\hline 0.5 & 32 & 0.38 & 0.211 & 0.563 & 0.278 & 0.048 & 0.010 \\
\hline 1.0 & 4 & 0.00 & 0.000 & 0.527 & - & 1.000 & 1.000 \\
\hline 1.5 & 35 & 0.14 & 0.048 & 0.303 & - & - & 0.304 \\
\hline 2.5 & 13 & 0.00 & 0.000 & 0.206 & - & - & - \\
\hline
\end{tabular}

burned (1 year post-burn) grasslands in Minnesota. The overall reproductive success during our study was only $20 \%$ (17 of 84 males successfully reproduced). Using the same index, Delisle and Savidge (1996) estimated $52 \%$ reproductive success for grasshopper sparrows in Nebraska, and Vickery et. al. (1992a) estimated 40-50\% reproductive success in Maine.

Higher reproductive success in pastures 0.5 year post-burn may be related to structural characteristics of potential nest sites available for this ground-nesting bird. Features of the nest site may have important implications for reproductive success by providing concealment from predators (Martin 1993, but see Vickery et al. 1992c) and ameliorating the microclimate at nests (With and Webb 1993). Small clumps of dense vegetation slightly larger than nest diameter (about $12.3 \mathrm{~cm}$ ) within more open patches (at least $4 \mathrm{~m}$ in diameter) were important factors influencing Florida grasshopper sparrow nest site selection on the study area (Delany and Linda 1998a). Changes in vegetation density and bare-ground cover among nest sites corresponded with an increase in plant material with time following fire (Delany and Linda 1998b). Optimal combinations of vegetation density for nest shielding and bare-ground cover for nest access, predator distraction displays, and foraging may occur 0.5 year after fire.

Type 1 hypothesis tests of linear, quadratic, cubic, and quintic terms in density in a GLM for reproductive success were nonsignificant ( $P>0.41$ for each term). Inspection of the plot of residuals from the analysis of reproductive success (without density terms in the model) versus residuals from the analysis of density indicated oscillation about zero (Fig. 3). Therefore, no simple trend or highly significant polynomial relationship between an individual's reproductive success and territory density was indicated. Our results support contentions that population density may not be a reliable indicator of habitat quality (Van Horne 1983), or the reproductive success of emberizine sparrows (Vickery et al. 1992b).

\section{Conclusions and Management Implications}

Our study encompassed the entire burn cycle at this location and results suggest increased reproductive success of Florida grasshopper sparrows at a population level 0.5 year following fire. However, our results should be viewed with caution. Data were obtained from only one population, and there was some confounding between calendar year and years postburn. The 2.5 years post-burn treatment occurred only in 1998 and 1999, and the 1.0 years post-burn treatment occurred only in 1999. Also, the sample size for the

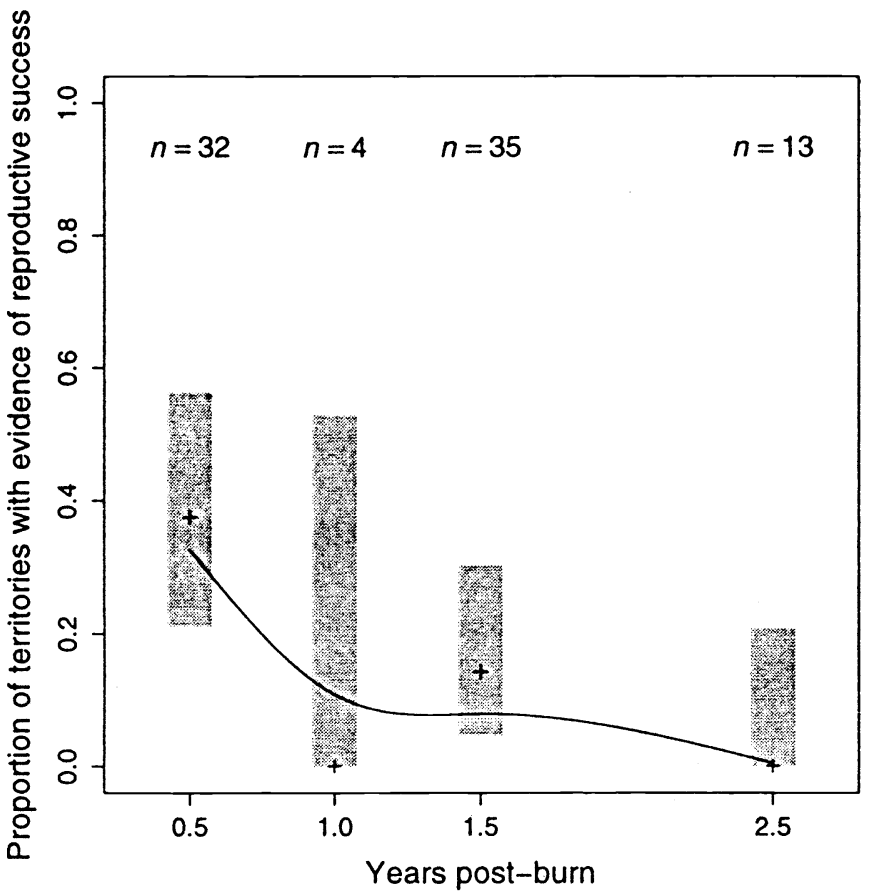

Fig. 2. Proportion of Florida grasshopper sparrow territories with reproductive success at years post-burn, Avon Park Air Force Range, Highlands County, Fla., 1997-1999. Plus symbols indicate empirical proportions, grey bars indicate exact $95 \%$ confidence intervals for proportions, and curved line indicates the fit of a smoothed curve (the cubic smoothing spline) to the empirical proportions.

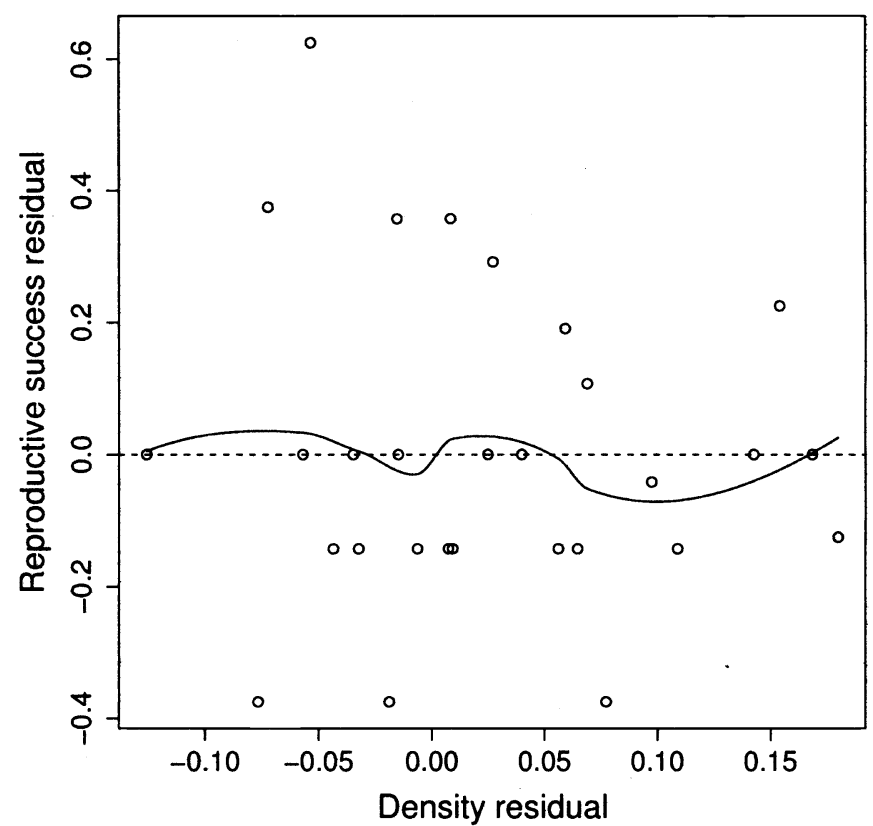

Fig. 3. Plot of residuals from the analysis of Florida grasshopper sparrow reproductive success versus residuals from the analysis of territory density, Avon Park Air Force Range, Highlands County, Fla., 1997-1999. Curve indicates nonparametric smooth fit (LOESS, with span $=3 / 4$ ). 
1.0 year post-burn treatment included only 3 plots.

Appropriate habitat management for most grasshopper sparrow populations appears to be the maintenance of grasslands that are frequently burned and devoid of forest edges (Johnson and Temple 1986, Delisle and Savidge 1996, Vickery 1996). Prescribed burning during the winter (December-March) at 2-3 year intervals seems to maintain suitable habitat for the Florida subspecies (Delany and Cox 1986). Winter burning also avoids potential nest loss from fires during the late-March through July breeding season. However, winter fires may alter the composition of Florida's dry prairies by increasing woody biomass and reducing native grasses and forbs (U.S. Fish and Wildlife Service 1999). Wiregrass normally does not flower unless burned during late-spring or summer, and some prairie forbs such as deer tongue (Carphephorus paniculatus Gmel.) and yellow bachelor's button (Polygala rugelii Chapm.) flower more conspicuously (Abrahamson 1984). Florida's prairie ecosystem has probably been maintained by a frequent fire cycle (1-4 years) caused by summer (May-September) thunderstorms (Abrahamson and Hartnett 1990, Chen and Gerber 1990). Prescribed burns that mimic a natural fire regime may better sustain this pyrogenic plant community. Florida grasshopper sparrows are probably adapted to summer fires, and may exhibit increased densities and a prolonged breeding season following such burns (Shriver et al. 1996, Shriver et al. 1999). Studies of Florida grasshopper sparrow abundance and productivity are needed to determine the effects of the seasonality of fire.

\section{Literature Cited}

Abrahamson, W.G. 1984. Species response to fire on the Florida Lake Wales Ridge. Amer. J. Bot. 71:35-43.

Abrahamson, W.G. and D.C. Hartnett. 1990. Pine Flatwoods and Dry Prairies. p. 103-150 In: R. L. Myers and J. J. Ewel (eds.) Ecosystems of Florida. Univ. Central Fla. Press, Orlando, Fla.

Carter, L.J., D. Lewis, L. Crockett, and J. Vega. 1989. Soil survey of Highlands County, Florida. USDA Soil Conserv. Serv., Sebring, Fla.

Chen, E. and J.F. Gerber. 1990. Climate. p. 11-13 In: R. L. Myers and J. J. Ewel (eds.) Ecosystems of Florida. Univ. Central Fla. Press, Orlando, Fla.

Curnutt, J.L., S.L. Pimm, and B.A. Maurer. 1996. Population variability of sparrows in space and time. Oikos 76:131-144.
Delany, M.F. and J.A. Cox. 1986. Florida grasshopper sparrow breeding distribution and abundance in 1984. Fla. Field Nat. 14:100-104.

Delany, M.F. and S.B. Linda. 1994. Characteristics of occupied and abandoned Florida grasshopper sparrow territories. Fla. Field Nat. 22:106-109.

Delany, M.F. and S.B. Linda. 1998a. Characteristics of Florida grasshopper sparrow nests. Wilson Bull. 110:136-139.

Delany, M.F. and S.B. Linda. 1998b. Nesting habitat of Florida grasshopper sparrows at Avon Park Air Force Range. Fla. Field Nat. 26:33-39.

Delany, M.F., H.M. Stevenson, and $R$. McCracken. 1985. Distribution, abundance, and habitat of Florida grasshopper sparrows. J. Wildl. Mgt. 49:626-631.

Delany, M.F., P.B. Walsh, B. Pranty, and D.W. Perkins. 1999. A previously unknown population of Florida grasshopper sparrows on Avon Park Air Force Range. Fla. Field Nat. 27:52-56.

Delisle, J.M. and J.A. Savidge. 1996. Reproductive success of grasshopper sparrows in relation to edge. Prairie Nat. 28:107-113.

ESRI. 1990. ArcView 3.0 GIS software. Environmental Systems Research Institute Inc. Redlands, Calif.

International Bird Census Committee. 1970. An international standard for a mapping method in bird census work recommended by the International Bird Census Committee. Aud. Field Notes 24:722-726.

Johnson, R.G. and S.A. Temple. 1986. Assessing habitat quality for birds nesting in fragmented tallgrass prairies. p. 245-249 In: J. Verner, M. L. Morrison, and C. J. Ralphs (eds.) Wildlife 2000: Modeling habitat relationships of terrestrial vertebrates. Univ. Wisc. Press, Madison, Wisc.

Lewis, C.E. 1964. Forage response to month of burning. U.S. For. Serv. Res. Note SE-35, Asheville, N.C.

Martin, T.E. 1993. Nest predation and nest sites, new perspectives on old patterns. BioSci. 43:523-532.

Milleson, J.F., R.L. Goodrick, and J.A. Van Arman. 1980. Plant communities of the Kissimmee River Valley. South Fla. Water Mgt. Dist. Tech. Pub. 80-7.

Peterjohn, B.G. and J.R. Sauer. 1999. Population status of North American grassland birds from the North American breeding bird survey, 1966-1996. Stud. in Avian Biol. 19:27-44.

SAS Inst., Inc. 1999. SAS OnlineDoc ${ }^{\mathrm{TM}}$ Version 7-1. SAS Institute Inc., Cary, NC.

Seber, G.A.F. 1982. The estimation of animal abundance and related parameters. Charles Griffin and Co., London and High Wycombe.

Shriver, W.G. and P.D. Vickery. 1999. Aerial assessment of potential Florida grasshopper sparrow habitat: conservation in a fragmented landscape. Fla. Field Nat. 27:1-9.

Shriver, W.G. and P.D. Vickery. 2001. Response of breeding Florida grasshopper and Bachman's sparrows to winter prescribed burning. J. Wildl. Mgt. 65:470-475.
Shriver, W.G., P.D. Vickery, and S.A. Hedges. 1996. Effects of summer burns on Florida grasshopper sparrows. Fla. Field Nat. 24:68-73.

Shriver, W.G., P.D. Vickery, and D.W. Perkins. 1999. The effects of summer burns on breeding Florida grasshopper and Bachman's sparrows. Stud. in Avian Biol. 19:144-148.

Smith, R.L. 1968. Grasshopper sparrow. p. 725-745 In: Life histories of North American cardinals, grosbeaks, buntings, towhees, finches, sparrows and allies, A. C. Bent (ed.). Pt. 2. U.S. Natl. Mus. Bull. 237. Washington D. C.

U.S. Fish and Wildlife Service. 1988. Recovery plan for Florida grasshopper sparrow. U.S. Fish and Wildlife Service, Atlanta, Ga.

U.S. Fish and Wildlife Service. 1999. Dry Prairie p. 279-339 In: South Florida multispecies recovery plan. U.S. Fish and Wildlife Service, Atlanta, Ga.

Van Horne, B. 1983. Density as a misleading indicator of habitat quality. J. Wildl. Mgt. 47:893-901.

Vickery, P.D. 1996. Grasshopper sparrow (Ammodramus savannarum). In: The birds of North America, number 239. A. Poole and F. Gill (eds.). Acad Natural Sci., Philadelphia, Penn., and Amer. Ornith. Union, Washington, D.C.

Vickery, P.D., M. Hunter, Jr., and J.V. Wells. 1992a. Use of a new reproductive index to evaluate relationship between habitat quality and breeding success. Auk 109:697-705.

Vickery, P.D., M. Hunter, Jr., and J.V. Wells. 1992b. Is density an indicator of breeding success? Auk 109:706-710.

Vickery, P.D., M.L. Hunter, Jr., and J.V. Wells. 1992c. Evidence of incidental nest predation and its effects on nests of threatened grassland birds. Oikos 63:281-288.

Walsh, P.B., D.A. Darrow, and J.G. Dyess. 1995. Habitat selection by Florida grasshopper sparrows in response to fire. Proc. Annu. Conf. Southeast. Assoc. Fish and Wildl. Agencies 49:340-347.

With, K.A., and D.R. Webb. 1993. Microclimate of ground nests: relative importance of radiative cover and wind breaks for three grassland species. Condor 95:401-413. 


\title{
Large ungulate habitat preference in Chobe National Park, Botswana
}

\author{
UYAPO J. OMPHILE AND JEFF POWELL
}

Authors are Lecturer, Botswana College of Agriculture, Gaborone; and Professor of Rangeland Livestock-Wildlife Relations, Wyoming Agricultural Experiment Station, Laramie, Wyo, USA.

\begin{abstract}
Both large ungulates and wildlife tourists tend to concentrate along the Chobe River in Chobe National Park, Botswana, during the dry season causing concern for wildlife habitat and the recreational experience for wildlife viewers. Therefore, ground reconnaissance inventory data of 5 most common large ungulates were collected during the early morning and late afternoon hours along tourist routes in 5 different habitat types every second month for a period of $\mathbf{2 4}$ months in Chobe National Park to determine their relative, seasonal habitat preference and availability for viewing by vehicular tourists. A total of 909 herds: greater kudu (Tragelaphus strepsiceros), 285; impala (Aepyceros melampus), 209; elephant (Loxodonta africana), 200; giraffe (Giraffa camelopardalis), 138; and buffalo (Syncerus caffra), 77 were observed during the 760 observation periods. The average frequency of observation of a herd of 1 or more of these 5 ungulates per habitat type was alkali flats, 3.42; floodplain grassland, 2.67; shrub savanna, 2.29; tree savanna, 1.04; and woodland, 0.30. This order of frequency of observation is highly correlated with nearness to the Chobe River, the major water source during the dry season. Elephant and giraffe were more wide-ranging than buffalo, impala, and kudu. During the dry season, all animals were seen more often on the floodplain grassland in the afternoon than in the morning. Giraffe were never seen in any habitat type in December, and impala were never seen in the woodland in any month. Our data confirm that tour operators interested primarily in providing their guests with a view of the greatest numbers of animals in a limited period of time are justified in congregating along the Chobe River during the dry season. However, as in most public wildlife reserves, Chobe National Park management is faced with the decision of how best to optimize the biological needs of Park animals and their habitat with the economic and recreational desires of Park users.
\end{abstract}

Key Words: Southern Africa, recreationists, buffalo, elephant, giraffe, impala, kudu

Chobe National Park is one of Botswana's major tourist attractions, primarily because of the variety of large animals present. In monetary terms, McNeeley (1988) estimated that a lion in Amboseli National Park, Kenya is worth $\$ 27,000$ per year in tourist attraction, and each elephant herd is worth $\$ 610,000$ per year. In 1999, about 89,540 tourists visited Chobe National Park

Research was funded in part by the Kellogg Foundation.

Manuscript accepted 24 Sept. 01

\author{
Resumen
}

Durante la estación seca los grandes ungulados y los turistas de la fauna silvestre tienden a concentrarse a lo largo del río Chobe en el Parque Nacional Chobe de Botswana, causando preocupación por el hábitat y la experiencia recreacional de los observadores de fauna silvestre. Por lo tanto, cada dos meses durante un periodo de 24 meses, se colectaron en el Parque Nacional Chobe datos de un inventario de reconocimiento terrestre de los 5 grandes ungulados mas comunes. La colecta de datos se realizo temprano en la mañana y en la tarde a lo largo de rutas de turistas en 5 diferentes tipos de hábitat para determinar la preferencia estacional relativa de hábitat y la disponibilidad para ser visto por turistas en vehículos. Un total de 909 manadas, 285 de Gran kudu (Tragelaphus strepsiceros), 209 de Impala (Aepyceros melampus), 200 de elefante (Loxodonta africana), 138 de jirafa; (Giraffa camelopardalis), 77 de búfalo (Syncerus caffra), se observaron durante $\mathbf{7 6 0}$ periodos de observación. La frecuencia promedio de observación de una manada de uno o más de estos 5 ungulados por tipo de hábitat fue de $\mathbf{3 . 4 2}$ para las llanuras alcalinas, 2.67 para los pastizales inundables, 2.29 para la savana con arbustos, 1.04 para la savana con árboles y 0.30 para los bosques. Este orden de frecuencia de observación esta altamente correlacionada con la cercanía del río Chobe, la mayor fuente de agua durante la época seca. El elefante y la girafa tuvieron un rango mas amplio de dispersión que el búfalo, el impala y el kudu. Durante la época seca todos los animales fueron vistos mas a menudo en los pastizales inundables durante la tarde que durante la mañana. Las jirafas nunca fueron vistas en diciembre en ninguno de los hábitats y los impalas no fueron vistos en el bosque en ninguno de los meses. Nuestros datos confirman que los operadores de recorridos interesados principalmente en proveer a sus invitados una vista con el mayor número de animales en un periodo de tiempo limitado son justificados en congregase a lo largo del río Chobe durante la época seca. Sin embargo, como en la mayoría de las reservas públicas de fauna silvestre, el manejo del Parque Nacional Chobe, se encara con la decisión de como optimizar mejor las necesidades biológicas de los animales del parque y su hábitat con los deseos económicos y recreacionales de los usuarios del parque.

for 108,700 tourist-days or 1.21 days/tourist (pers. commun., Botswana Dep. National Parks and Wildlife). Tourists included $27 \%$ who drove their own vehicles and $73 \%$ guided by commercial tour operators. Most $(56 \%)$ of the private visitors were from Southern Africa, whereas guided visitors were primarily $(81.3 \%)$ from countries outside Africa. Private visitors provided $40 \%$ of 
the total 21,833 vehicle-days with an average of 3.5 people per vehicle; tour operators provided $60 \%$ of the vehicle-days with an average of 6.0 people per vehicle.

The majority of visitors tour Chobe National Park during the dry, winter season (pers. commun., Botswana Dept. National Parks and Wildlife) because the temperature is cooler, the risk of malaria is lower, and the loss of leaves from deciduous trees and shrubs during the dry season enhances wildlife viewing (pers. observ.). In addition, nearly all large animals tend to concentrate near the Chobe River along the northern edge of the Park at this time because other water sources are limited.

The concentration of animals along the northern edge of the Park during the dry season attracts wildlife-viewing tourists, thus apparently leaving much of the Park under-utilized by both animals and tourists at this time. The Botswana Department of National Parks and Wildlife is concerned about the "over-crowding" of animals and tourists along the northern edge of the Park, and therefore, the objective of this study was to document the numbers of herds of 5 common ungulate species in different habitat types and in different seasons as "seen by vehicular tourists". The 5 species included 2 browsers, giraffe (Giraffa camelopardalis) and greater kudu (Tragelaphus strepsiceros), 2 mixed feeders, elephant (Loxodonta Africana) and impala (Aepyceros melampus), and 1 grazer, buffalo (Syncerus caffra) to reflect the range of large ungulate herbivory in the study area.

\section{Materials and Methods}

\section{Study Area}

Location and general description.-The study area is located in the northern part of Chobe National Park, Botswana. The Park covers an area of $11,000 \mathrm{~km}^{2}$ and lies between longitude $24^{\circ}$ and $25^{\circ} \mathrm{E}$ and latitude $18^{\circ}$ and $19^{\circ} \mathrm{S}$ (Child 1968). It is partially drained by the Chobe River which forms the boundary between northeastern Botswana and eastern Carprivi Strip of Namibia. The river meanders through an extensive floodplain which stretches east almost unbroken to the Zambezi River in Zambia and abruptly gives way to a sand ridge composed of a basaltic core overlain by the Kgalagadi sand to the south (Child and Von Richter 1968). The interior of the Park is drained by the ephemeral Savuti and Ngwezumba rivers and numerous intermittent streams.

Climate.-Rainfall is seasonal, falling mainly between November and April. Precipitation at Kasane averages $690 \mathrm{~mm}$ (Child and Von Richter 1968) with a $70-80 \%$ probability of exceeding $500 \mathrm{~mm}$ in any one year (Field 1978). The remaining months of the year are dry, and the degree of dryness increases progressively from June to October. Maximum and minimum average monthly temperatures range from 36 to $19^{\circ} \mathrm{C}$, but decline to winter minima in June and July when the range is between 26 and $9 \mathrm{C}$. Temperatures reach a maximum in October when the average maximum over 24 years was $35^{\circ} \mathrm{C}$ and the minimum was $19^{\circ} \mathrm{C}$ (Child and Von Richter 1968).

Topography.-Northeastern Botswana, like the rest of the country, is relatively flat terrain characterized by low elevation ranging from 100 to $1,000 \mathrm{~m}$ (Field 1978). Within the park, however, elevations only range from 910 to $1,050 \mathrm{~m}$ (FGU undated).

Soils and vegetation.-The Park is ecologically divided into 5 zones; the Chobe floodplain grassland in the north, Mababe depression and Savuti channel and marsh in the southwest, the Pan area into which the Ngwezumba River empties, and the Kgalagadi woodland which covers most of the Park. The study site includes both Kgalagadi woodland and Chobe floodplains. Within the woodland, 2 additional areas (i.e., tree savanna and shrub savanna) were identified for the purposes of the study. These areas, together with a third habitat type, the alkali flats, were described (Selous 1881, Henry 1966) and referred to (Child 1968) as variations within a broader vegetation type. Therefore, we considered 5 areas (i.e., floodplain grassland, alkali flats, shrub savanna, tree savanna, and Kgalagadi woodland) as 5 ecologically distinct habitat types affecting ungulate behavior and ecology in this study.

The total area of study is about $575 \mathrm{~km}^{2}$ or about $5 \%$ of the total Park area. Within the study area, the habitat type composition is as follows: woodland $(55.6 \%)$, tree savanna $(23.7 \%)$, floodplain grassland $(11.1 \%)$, shrub savanna $(5.2 \%)$, and alkali flats $(4.2 \%)$.

The Chobe floodplain grasslands, an integral part of the Chobe River system, is a linear area of approximately $90 \mathrm{~km}^{2}$ bordering and including part of the river. The soils differ, but are characterized by calcic gleysols and eutric arenosols, deep to very deep, poorly to imperfectly drained, very dark sand clay to clay interspersed by riverine alluvials on dead river courses (FGU undated).

The Kgalagadi woodland is an open woodland, probably fire-induced as evi- dent from tree stumps and bark-bearing fire scars. The area tends towards a forest to the east between Kasane and Lesoma, stretches south from the crest of the savanna (sandridge) to the edge of the Kakulani plains around Ngwezumba River and from Kasane, southwest to Kachikau. The soils (FGU undated) are predominantly ferralic arenosols to eutric arenosols, deep to very deep and excessively drained. Locally, these soils are interspersed with a variety of loamy sands on alluvial deposits in the valleys.

Savanna soils are consistently sandy and lack interruptions except on rocky outcrops where larger rock boulders or loose gravel replace the sand. The habitat abruptly gives way either to the Chobe floodplains, alkali flats, or the shrub savanna to the north and west, and the Kgalagadi woodland to the south. Although logging was reported (Miller 1939), and signs of that activity are still evident, especially to the north, the industry does not appear to have significantly affected the tree population.

The shrub savanna, an extension of the tree savanna, but with an ecologically distinct characteristic resulting from excessive logging during the turn of the century (Child 1968) and excessive use of the woody vegetation by elephants, is located east of the sand ridge and alkali flats and west of the Sedudu valley. The soils are generally sandy, but stretches of harder loamy soil, especially around the few pans, are common.

The alkali flats is an open area, though some portions, especially those within the sandy soils catena, have a closed canopy of tall brush. This area, believed to be an elevated floodplain and named "Puku" flats (Selous 1881) is oblong in shape and about 9-13 km long, but rather narrow (0.5-1.2 km wide).

\section{Observational Methods}

The 5 animal species selected for study were observed in each of the 5 habitat types delineated in the study area. Reconnaissance tours (Dekker et al. 1996) were conducted during the first 3 hours of daylight and the last 3 hours before dark every other day for a minimum of 5 and a maximum of 7 different days per month during both wet and dry seasons from October 1993 through August 1995. Observational data recorded for each herbivore included habitat type, location within habitat type, and distance (m) from observer to animal.

The line transect method (Mugangu et al. 1995) was used for data recording. The 
route of each reconnaissance tour was limited by vehicular accessibility. However, all habitat types were sampled during each observation period, and the route order was randomized by and within habitat types to obtain an estimate of the preferred habitat types based on relative numbers of herds of different species of animals sighted in each habitat type. Animals seen along habitat type ecotones were not recorded, and only those sighted in a habitat type that was currently being monitored were considered valid observations.

The total number of habitat preference samples (observation means) per species was: 2 years x 6 months/year x 5 habitat types/month x 5-7 days/month $\times 2$ times /day $=760$ observation periods. The number of observations of herds of an herbivore in each habitat type was adjusted by a factor to compensate for the different distances traveled in different habitat types. The distances traveled each observation period in the different habitat types were alkali flats $(28.4 \mathrm{~km})$, floodplain grassland $(23.4 \mathrm{~km})$, shrub savanna $(21.3 \mathrm{~km})$, tree savanna $(40.7 \mathrm{~km})$, and woodland $(30.5 \mathrm{~km})$ for a total of $144 \mathrm{~km}$ or an average of $28.8 \mathrm{~km}$ per habitat type each observation period.

The recording team included a driver and 2 observers in the back of a pickup truck. Each observer recorded individually, and the 2 observations were averaged for each kind of herbivore. Due to differences in vegetation cover density, the sighting distance (Dekker et al. 1996) varied among the different vegetation types. The initial sighting distance was disregarded because of the emphasis on the "tourist viewing perspective". In other words, the objective was to determine how many herds of a species a tourist would see from a vehicle along routes of vehicular access in different habitat types in Chobe National Park. Not all species were observed in all habitat types or in all observation periods. However, if more than one herd of the same species was observed at different locations in the same habitat type during the same observation period, each herd was counted as a separate observation.

The general linear model (GLM) procedure (SAS 1985) was used for a split (time of day)- split (habitat type) - plot (month) experimental design (Steel and Torrie
1980) using years as replications to determine the level of significance among differences in habitat type preference for different times of day and months by different herbivore species. Where significant $(\mathrm{P}<0.05)$ differences were observed, Tukey's HSD was used to separate the means. All differences discussed are statistically significant at the $5 \%$ level unless otherwise indicated.

\section{Results}

\section{Weather}

Annual precipitation during the 2 wetto-dry years from October, 1993 through September, 1995 was about equal but $20 \%$ less in both years than the long-term average. The early wet season rains in the first year (PY94; 10/93-9/94) were about average, but there were only limited rains after February 1994. Early wet season precipitation in PY95 (10/94-9/95) was less than that in PY94; however, above average rainfall in February 1995 brought the cumulative total up to equal that of PY94. The net effects were to create normal plant

Table 1. Numbers (mean \pm SE) of buffalo herds observed per time period during different months, times of day, and in different habitat types in Chobe National Park, Botswana. ( $N=6 / \mathrm{month} /$ time period/habitat type). Means for habitat types for the same time or month followed by a different letter are statistically different at the $5 \%$ level of probability. Significant $(P<0.05)$ differences between means for different times within habitat type and month are indicated by '*',

\begin{tabular}{|c|c|c|c|c|c|c|c|}
\hline \multirow[b]{2}{*}{ Month } & \multirow[b]{2}{*}{ Time $^{2}$} & \multicolumn{5}{|c|}{ Habitat Type $^{1}$} & \multirow[b]{2}{*}{ HTMean $^{3}$} \\
\hline & & $\mathrm{AF}$ & $\mathrm{FG}$ & SS & TS & WL & \\
\hline \multirow[t]{3}{*}{ Year $^{4}$} & $\mathrm{AM}$ & $0.17 \mathrm{a} \pm 0.04$ & $0.2 b \pm 0.02$ & $0.11 \mathrm{ab} \pm 0.04$ & $0.18 * a \pm 0.04$ & $0.01 b \pm 00.01$ & $0.10 \pm 0.02$ \\
\hline & PM & $\underline{0.10 b \pm 0.03}$ & $\underline{0.43 * \mathrm{a} \pm 0.08}$ & $0.09 \mathrm{~b} \pm 0.04$ & $0.02 b \pm 0.01$ & $0.0 \mathrm{~b} \pm 0.0$ & $\underline{0.13 \pm 0.02}$ \\
\hline & TMean $^{5}$ & $\overline{0.13 b \pm 0.03}$ & $0.22 \mathrm{a} \pm 0.04$ & $\overline{0.10 b \pm 0.03}$ & $\overline{0.10 b \pm 0.02}$ & $0.01 \mathrm{c} \pm 0.01$ & $0.11 \pm 0.01$ \\
\hline \multirow[t]{3}{*}{ Dec. } & $\mathrm{AM}$ & $0.25 \pm 0.13$ & $0.10 \pm 0.10$ & $0.11 \pm 0.11$ & $0.12 \pm 0.08$ & $0.0 \pm 0.0$ & $0.12 \pm 0.04$ \\
\hline & PM & $\underline{0.09 \pm 0.09}$ & $\underline{0.21 \pm 0.14}$ & $\underline{0.0 \pm 0.0}$ & $\underline{0.0 \pm 0.0}$ & $\underline{0.0 \pm 0.0}$ & $\underline{0.06 \pm 0.03}$ \\
\hline & TMean & $0.17 \pm 0.08$ & $0.15 \pm 0.09$ & $0.06 \pm 0.06$ & $0.06 \pm 0.04$ & $0.0 \pm 0.0$ & $0.09 \pm 0.03$ \\
\hline \multirow[t]{3}{*}{ Feb. } & $\mathrm{AM}$ & $0.07 \pm 0.07$ & $0.0 \pm 0.0$ & $0.21 \pm 1.04$ & $0.11 \pm 0.07$ & $0.0 \pm 0.0$ & $0.08 \pm 0.04$ \\
\hline & PM & $\underline{0.16 \pm 0.11}$ & $0.0 \pm 0.0$ & $\underline{0.10 \pm 1.00}$ & $\underline{0.11 \pm 0.07}$ & $\underline{0.0 \pm 0.0}$ & $\underline{0.07 \pm 0.03}$ \\
\hline & TMean & $\overline{0.11 \pm 0.06}$ & $\overline{0.0 \pm 0.0}$ & $\overline{0.16 \pm 0.09}$ & $\overline{0.11 \pm 0.05}$ & $\overline{0.0 \pm 0.0}$ & $\overline{0.08 \pm 0.02}$ \\
\hline \multirow[t]{3}{*}{ Apr. } & $\mathrm{AM}$ & $0.23 \pm 0.12$ & $0.0 \pm 0.0$ & $0.10 \pm 0.10$ & $0.22 * \pm 0.09$ & $0.0 \pm 0.0$ & $0.11 \pm 0.04$ \\
\hline & PM & $\underline{0.16 \pm 0.11}$ & $\underline{0.28 * \pm 0.15}$ & $\underline{0.10 \pm 0.10}$ & $\underline{0.0 \pm 0.0}$ & $\underline{0.0 \pm 0.0}$ & $\underline{0.11 \pm 0.04}$ \\
\hline & TMean & $0.20 \pm 0.08$ & $0.14 \pm 0.08$ & $0.10 \pm 0.07$ & $0.11 \pm 0.05$ & $\overline{0.0 \pm 0.0}$ & $0.11 \pm 0.03$ \\
\hline \multirow[t]{3}{*}{ June } & $\mathrm{AM}$ & $0.25^{*} \pm 0.13$ & $0.0 \pm 0.0$ & $0.11 \pm 0.11$ & $0.12 \pm 0.08$ & $0.08 \pm 0.08$ & $0.11 \pm 0.04$ \\
\hline & PM & $\underline{0.0 \pm 0.0}$ & $\underline{0.62 * \pm 0.19}$ & $\underline{0.11 \pm 0.11}$ & $\underline{0.0 \pm 0.0}$ & $\underline{0.0 \pm 0.0}$ & $\underline{0.15 \pm 0.05}$ \\
\hline & TMean & $0 . \overline{13 \pm 0.07}$ & $0.31 \pm 0.11$ & $\overline{0.11 \pm 0.08}$ & $0.06 \pm 0.04$ & $0.04 \pm 0.04$ & $0.13 \pm 0.03$ \\
\hline \multirow[t]{3}{*}{ Aug. } & AM & $0.09 \pm 0.09$ & $0.0 \pm 0.0$ & $0.12 \pm 0.12$ & $0.26^{*} \pm 0.11$ & $0.0 \pm 0.0$ & $0.09 \pm 0.04$ \\
\hline & PM & $\underline{0.18 \pm 0.12}$ & $\underline{0.90^{*} \pm 0.34}$ & $\underline{0.0 \pm 0.0}$ & $\underline{0.0 \pm 0.0}$ & $\underline{0.0 \pm 0.0}$ & $\underline{0.22 \pm 0.08}$ \\
\hline & TMean & $0 . \overline{14 b \pm 0.08}$ & $\overline{0.45 a \pm 0.19}$ & $0 . \overline{06 \mathrm{~b} \pm 0.06}$ & $0.13 b \pm 0.06$ & $0.0 \mathrm{~b} \pm 0.0$ & $0.16 \pm 0.05$ \\
\hline \multirow[t]{3}{*}{ Oct. } & AM & $0.15 \pm 0.10$ & $0.0 \pm 0.0$ & $0.0 \pm 0.0$ & $0.25^{*} \pm 0.09$ & $0.0 \pm 0.0$ & $0.08 \pm 0.03$ \\
\hline & PM & $\underline{0.0 \pm 0.0}$ & $\underline{0.62 * \pm 0.17}$ & $\underline{0.19 \pm 0.13}$ & $\underline{00.0 \pm 0.0}$ & $\underline{0.0 \pm 0.0}$ & $\underline{0.16 \pm 0.05}$ \\
\hline & TMean & $0.07 b \pm 0.05$ & $0.31 \mathrm{a} \pm 0.10$ & $0.10 b \pm 0.07$ & $0.13 b \pm 0.05$ & $0 . \overline{0 b \pm 0.0}$ & $0.12 \pm 0.03$ \\
\hline
\end{tabular}

${ }^{1} \mathrm{AF}=$ alkali flats; $\mathrm{FG}=$ floodplain grassland; $\mathrm{SS}=$ shrub savanna; $\mathrm{TS}=$ tree savanna; $\mathrm{WL}=$ woodland.

${ }^{2} \mathrm{AM}=1^{\text {st }} 3$ hours after daylight; $\mathrm{PM}=1^{\text {st }} 3$ hours before dark.

${ }^{3} \mathrm{HTMean}=$ Mean for all habitat types per time or month.

${ }_{5}^{4}$ Year = Mean for all months per time and per habitat type.

${ }^{5}$ TMean $=$ Mean for both AM and PM per habitat type or month. 
growth during the early and mid wet season of PY94 with an early onset of the dry season. In PY95, early and mid season growth in PY95 was less than average, but the above average late wet season rains delayed the onset of the dry season.

\section{Relative Frequency of Observation of Herds}

A total of 909 herds of animals (kudu, 285; impala, 209; elephant, 200; giraffe, 138; and buffalo, 77) were observed over the 760 observation periods for an average of 1.20 herds per observation period and one herd of some species for every 15.5 $\mathrm{km}$ of route traveled. The average, adjusted (i.e., for different size habitat types) number of herds per observation period per habitat type for all animals combined was as follows: alkali flats (3.42), floodplain grassland (2.67), shrub savanna (2.29), tree savanna (1.04), and woodland (0.30).

The total number of observations for all herds was similar in PY94 (473) in PY95 (436) and for the wet (427) and dry seasons (482) seasons. However, there were large differences in the numbers of observations of herds due to kind of animal, month, habitat type, and time of day.

\section{Buffalo}

The average number of herds of buffalo for all observation periods was about 0.11 and varied only from 0.08 to 0.16 for the average of any month (Table 1). However, there were differences between habitat types and between times of day.

For the year, the greatest number of herds of buffalo were observed in the floodplain grassland and the lowest number in the woodland habitat type. This varied with time of day. During the morning, buffalo were observed most often in the tree savanna and alkali flats and least often in the floodplain grassland and woodland. Except for June, buffalo were never observed in the woodland. During the afternoon, buffalo were observed most often in the floodplain grassland. Buffalo sightings were much more numerous in the tree savanna in the morning than the afternoon and much more numerous in the floodplain grassland during afternoon than morning. These differences occurred, however, only in the late wet season (April) and all of the dry season (JuneOctober).
There was no significant difference in buffalo sightings in different habitat types during any month of the wet season (December-April) or the early part (June) of the dry season, but buffalo sightings were greater in the floodplain grassland in the mid (August) and late (October) dry season than in other habitat types.

\section{Elephant}

The overall average number of herds of elephant observed per observation period was 0.42 (Table 2). The numbers of herds sighted were similar during the wet season, then tended to increase and peak at the end of the dry season. The annual average elephant sightings per habitat type were in descending order as follows: floodplain grassland $(0.80)>$ alkali flats $(0.53) \geq$ shrub savanna $(0.41) \geq$ tree savanna $(0.27)>$ woodland $(0.11)$. In the morning, elephant sightings were about equal and more numerous in the alkali flats, shrub, and tree savannas than in the floodplain grassland or woodland, but in the afternoon elephant sightings were much greater in the floodplain grassland

Table 2. Numbers (mean \pm SE) of elephant herds observed per time period during different months, times of day, and in different habitat types in Chobe National Park, Botswana. ( $\mathrm{N}=6 / \mathrm{month} / \mathrm{time} / \mathrm{habitat}$ type). Means for habitat types for the same time or month followed by a different letter are statistically different at the $5 \%$ level of probability. Significant $(\mathrm{P}<0.05)$ differences between means for different times within habitat type and month are indicated by '**'.

\begin{tabular}{|c|c|c|c|c|c|c|c|}
\hline \multirow[b]{2}{*}{ Month } & \multirow[b]{2}{*}{ Time $^{2}$} & \multicolumn{5}{|c|}{ Habitat Type $^{1}$} & \multirow[b]{2}{*}{ HTMean $^{3}$} \\
\hline & & $\mathrm{AF}$ & FG & SS & TS & WL & \\
\hline \multirow[t]{2}{*}{ Year $^{4}$} & $\mathrm{AM}$ & $0.61 \mathrm{a} \pm 0.09$ & $0.16 b \pm 0.07$ & $0.56 a \pm 0.10$ & $0.45 * a \pm 06$ & $0.19 * b \pm 04$ & $0.39 \pm 04$ \\
\hline & PM & $0.45 b \pm 0.08$ & $1.44 * a \pm 0.18$ & $0.25 b c \pm 0.07$ & $\underline{0.09 c \quad \pm 03}$ & $\underline{0.03 c \pm 02}$ & $\underline{0.45 \pm 05}$ \\
\hline \multirow[t]{2}{*}{ Dec. } & $\mathrm{AM}$ & $1.10 \pm 0.26$ & $0.0 \pm 0.0$ & $0.68 \pm 0.26$ & $0.35 \pm 0.18$ & $0.16 \pm 0.11$ & $0.46 \pm 10$ \\
\hline & PM & $\underline{0.76 \pm 0.25}$ & $\underline{0.21 \pm 0.21}$ & $\underline{0.45 \pm 0.25}$ & $\underline{0.23 \pm 0.13}$ & $\underline{0.08 \pm 0.08}$ & $\underline{0.35 \pm 09}$ \\
\hline \multirow{2}{*}{ Feb. } & PM & $\underline{0.58 \pm 0.21}$ & $\underline{0.10 \pm 0.10}$ & $\underline{0.73 \pm 0.25}$ & $\underline{0.05 \pm 0.05}$ & $\underline{0.0 \pm 0.0}$ & $\underline{0.30 \pm 08}$ \\
\hline & TMean & $0 . \overline{49 a b \pm 0.14}$ & $0.05 \mathrm{~d} \pm 0.05$ & $0.78 \mathrm{a} \pm 0.19$ & $0 . \overline{42 b c \pm 0.11}$ & $0.1 \overline{1 c d \pm 0.06}$ & $\overline{0.37 \pm 06}$ \\
\hline \multirow[t]{3}{*}{ Apr. } & $\mathrm{AM}$ & $0.31 \pm 0.18$ & $0.0 \pm 0.0$ & $0.52 \pm 0.29$ & $0.49^{*} \pm 0.17$ & $0.07 \pm 0.07$ & $0.28 \pm 08$ \\
\hline & PM & $\underline{0.55 \pm 0.19}$ & $1.70 * \pm 0.41$ & $\underline{0.10 \pm 0.10}$ & $\underline{0.11 \pm 0.07}$ & $\underline{0.07 \pm 0.07}$ & $\underline{0.51 \pm 12}$ \\
\hline & TMean & $0.43 \mathrm{ab} \pm 0.13$ & $0.85 \mathrm{a} \pm 0.26$ & $0.31 b \pm 0.16$ & $0.30 \mathrm{~b} \pm 0.10$ & $0.07 \mathrm{~b} \pm 0.05$ & $0.39 \pm 07$ \\
\hline \multirow[t]{3}{*}{ Aug. } & $\mathrm{AM}$ & $0.46 \pm 0.25$ & $0.11 \pm 0.11$ & $0.49 \pm 0.21$ & $0.51 * \pm 0.17$ & $0.34 * \pm 0.10$ & $0.38 \pm 0.08$ \\
\hline & PM & $\underline{0.28 \pm 0.20}$ & $2.35^{*} \pm 0.42$ & $\underline{0.12 \pm 0.12}$ & $\underline{0.06 \pm 0.06}$ & $\underline{0.0 \pm 0.0}$ & $\underline{0.56 \pm 0.15}$ \\
\hline & TMean & $0.37 \mathrm{~b} \pm 0.16$ & $1.23 a \pm 0.32$ & $0.31 \mathrm{~b} \pm 0.12$ & $0.29 b \pm 0.10$ & $0.17 \mathrm{~b} \pm 0.08$ & $0.47 \pm 0.09$ \\
\hline \multirow[t]{3}{*}{ Oct. } & $\mathrm{AM}$ & $1.01 * \pm 0.24$ & $0.79 \pm 0.33$ & $0.58 \pm 0.27$ & $0.20 \pm 0.12$ & $0.07 \pm 0.07$ & $0.53 \pm 11$ \\
\hline & PM & $\underline{0.07 \pm 0.07}$ & $2.55^{*} \pm 0.51$ & $\underline{0.10 \pm 0.10}$ & $\underline{0.05 \pm 0.05}$ & $\underline{0.0 \pm 0.0}$ & $\underline{0.55 \pm 16}$ \\
\hline & TMean & $0.54 \mathrm{~b} \pm 0.15$ & $\overline{1.67 a \pm 0.34}$ & $0 . \overline{34 b \pm 0.15}$ & $0.13 b \pm 0.06$ & $0.03 b \pm 0.03$ & $\overline{0.54 \pm 10}$ \\
\hline
\end{tabular}

$\mathrm{AF}=$ alkali flats; $\mathrm{FG}=$ floodplain grassland; $\mathrm{SS}=$ shrub savanna; $\mathrm{TS}=$ tree savanna; $\mathrm{WL}=$ woodland.

${ }^{2} \mathrm{AM}=1^{\text {st }} 3$ hours after daylight; $\mathrm{PM}=1^{\text {st }} 3$ hours before dark.

${ }^{3} \mathrm{HTMean}=$ Mean for all habitat types per time or month.

${ }_{5}^{4}$ Year = Mean for all months per time and per habitat type.

${ }^{5}$ TMean $=$ Mean for both AM and PM per habitat type or month 
Table 3. Numbers (mean \pm SE) of giraffe herds observed per time period during different months, times of day, and in different habitat types in Chobe National Park, Botswana. ( $=6 / \mathrm{month} /$ time period/habitat type). Means for habitat types for the same time or month followed by a different letter are statistically different at the $5 \%$ level of probability. Significant $(P<0.05)$ differences between means for different times within habitat type and
month are indicated by '*

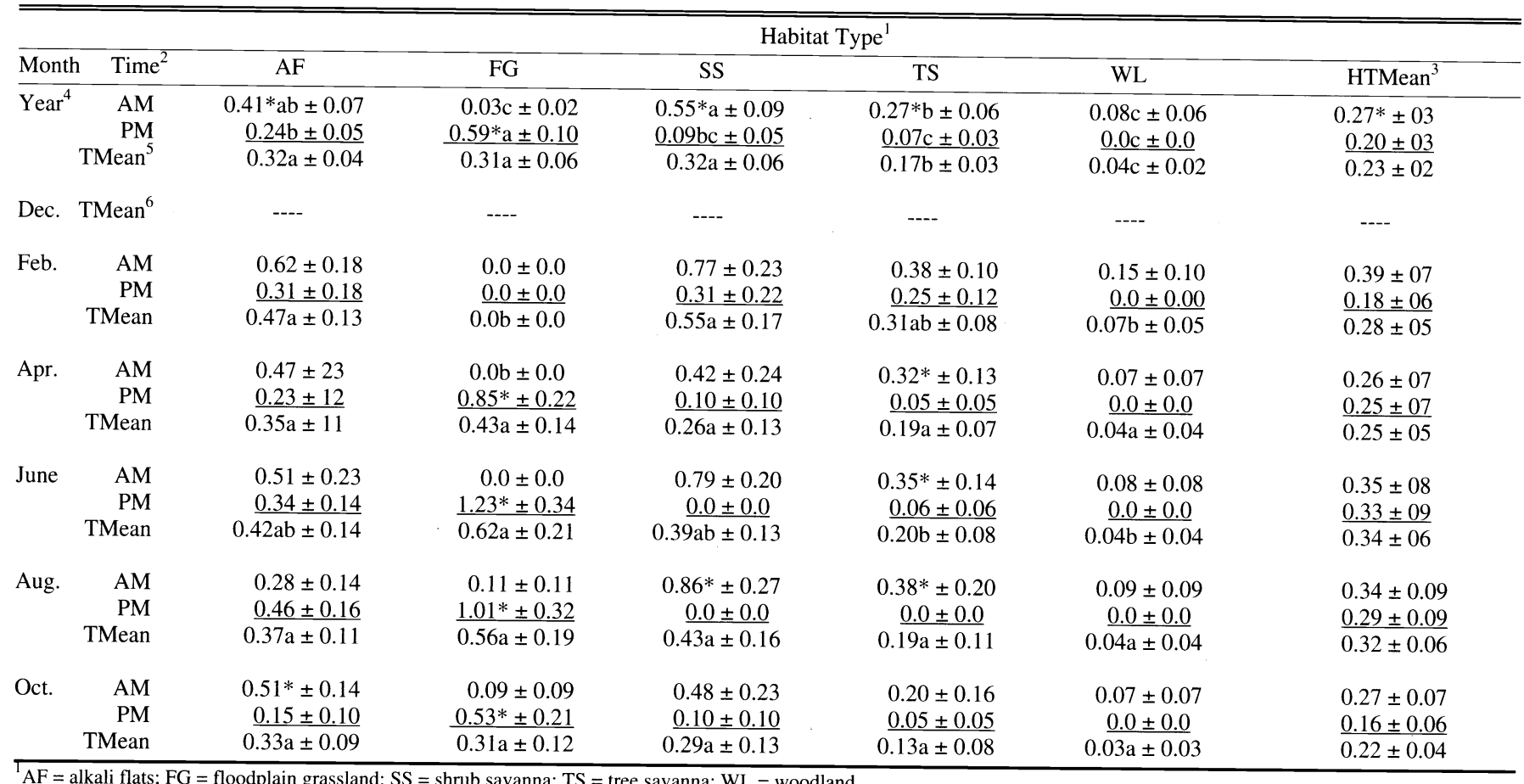

$\mathrm{AF}=$ alkali flats; $\mathrm{FG}=$ floodplain grassland $; \mathrm{SS}=$ shrub savanna; $\mathrm{TS}=$ tree savanna; $\mathrm{WL}=$ woodland

${ }_{3}^{2} \mathrm{AM}=1^{\text {st }} 3$ hours after daylight; $\mathrm{PM}=1^{\text {st }} 3$ hours before dark.

${ }^{3}$ HTMean $=$ Mean for all habitat types per time or month.

${ }^{4}$ Year = Mean for all months per time and per habitat type.

${ }^{5}$ TMean = Mean for both AM and PM per habitat type or month

${ }^{6}$ No giraffe were seen anywhere in the study area in December.

than anywhere else. Differences due to time of day were greatest for the tree savanna and woodland (i.e., the 2 habitat types farthest from the Chobe River) and the floodplain grassland (i.e., closest to the river).

Elephant sightings were relatively low in the floodplain grassland during the early and mid wet season, but were greater in the floodplain grassland than in any other habitat type thereafter. By the end of the dry season in October, elephant sightings in the floodplain grassland were 3 times greater than the overall habitat type average. However, elephants were never sighted in the floodplain grassland in the morning until the middle of the dry season. Conversely, elephant sightings were greater in the morning than in the afternoon in the tree savanna and woodland until late in the dry season. At this time, elephants tended to concentrate in the alkali flats in the morning and move out onto the floodplain grasslands in the afternoon.

\section{Giraffe}

The average number of giraffe sightings for all months, habitat types, and times of day was 0.23 (Table 3 ). This number was relatively similar for all months except
December, when giraffe were never seen anywhere in the study area.

On an annual basis, giraffe were most often seen and seen equally in the alkali flats, floodplain grassland, and shrub savanna, less often in the tree savanna, and least often in the woodland. However, as with the elephants, giraffe sightings were higher in the morning in the alkali flats and shrub savanna than elsewhere and higher in the afternoon in the floodplain grassland than elsewhere. Giraffe were never seen in the woodland in the afternoon.

The major difference in habitat preference occurred in February (mid wet season) and in June (beginning of the dry season). Giraffe preference for the floodplain grassland tended to increase from February to June and then decrease through October with the greatest difference in the afternoon.

\section{Impala}

The overall average number of impala sightings was 0.53 per observation period (Table 4). Unlike the sightings for other animals, impala sightings were significantly lower in April at the end of the wet season than during other months. Otherwise, the number of impala sightings during different months was very similar.

Impala preference for the alkali flats was about twice that for any other habitat type, although they were seen most often in the afternoon on the floodplain grassland. Impala were also seen about twice as often in the shrub savanna in the morning as in the afternoon and more often in the alkali flats in the morning than in the afternoon. Impala were never seen in the floodplain grasslands in the morning during any month, nor were impala ever seen in the woodland at either time of day or during any month of the year. The preference of impala for the alkali flats in the morning and the floodplain grassland in the afternoon became more pronounced as the seasons changed from wet to dry.

Impala preference for the alkali flats was much higher in the early-mid wet season and dry season than in the late wet season (i.e., April), and this low number of sightings in April on the alkali flats was the primary reason for the low monthly average in April for all habitat types. Impala preference for the floodplain grassland increased from low in the early-mid wet season to high in the mid-late dry season. 
Table 4. Numbers (mean \pm SE) of impala herds observed per time period during different months, times of day, and in different habitat types in Chobe National Park, Botswana. ( $N=6 /$ month/time/habitat type). Means for habitat types for the same time or month followed by a different letter are statistically different at the $5 \%$ level of probability. Significant $(P<0.05)$ differences between means for different times within habitat type and month are indicated by '*'.

\begin{tabular}{|c|c|c|c|c|c|c|c|}
\hline \multirow[b]{2}{*}{ Month } & \multirow[b]{2}{*}{ Time $^{2}$} & \multicolumn{5}{|c|}{ Habitat Type ${ }^{\prime}$} & \multirow[b]{2}{*}{ HTMean $^{3}$} \\
\hline & & $\mathrm{AF}$ & FG & SS & TS & WL & \\
\hline \multirow[t]{3}{*}{ Year $^{4}$} & $\mathrm{AM}$ & $1.45^{*} \mathrm{a} \pm 0.10$ & $0.0 \mathrm{c} \pm 0.0$ & $0.80 * b \pm 0.12$ & $0.14 c \pm 03$ & 5 & $0.48 \pm 04$ \\
\hline & PM & $\underline{1.09 a \pm 0.13}$ & $\underline{1.35 * \mathrm{a} \pm 0.17}$ & $\underline{0.34 b \pm 0.10}$ & $\underline{0.05 c \pm 02}$ & $\underline{----}$ & $\underline{0.57 \pm 06}$ \\
\hline & TMean $^{6}$ & $1.27 \mathrm{a} \pm 0.08$ & $0.67 b \pm 0.10$ & $0.57 b \pm 0.08$ & $0.09 \mathrm{c} \pm 02$ & $\overline{---}$ & $0.53 \pm 04$ \\
\hline \multirow[t]{3}{*}{ Dec. } & AM & $1.78 \pm 0.18$ & $0.0 \pm 0.0$ & $1.13 \pm 0.37$ & $0.0 \pm 0.0$ & ---- & $0.58 \pm 12$ \\
\hline & PM & $1.86 \pm 0.37$ & $\underline{0.21 \pm 0.21}$ & $\underline{0.68 \pm 0.31}$ & $\underline{0.06 \pm 0.06}$ & $\underline{----}$ & $\underline{0.56 \pm 14}$ \\
\hline & TMean & $1.82 a \pm 0.20$ & $0.10 \mathrm{c} \pm 0.10$ & $0.90 \mathrm{~b} \pm 0.24$ & $0.03 \mathrm{c} \pm 0.03$ & $\overline{----}$ & $0.57 \mathrm{a} \pm 09$ \\
\hline \multirow[t]{3}{*}{ Feb. } & $\mathrm{AM}$ & $1.67 \pm 0.20$ & $0.0 \pm 0.0$ & $1.06^{*} \pm 0.16$ & $0.16 \pm 0.09$ & ---- & $0.60 \pm 0.12$ \\
\hline & PM & $\underline{1.81 \pm 0.36}$ & $\underline{0.19 \pm 0.19}$ & $\underline{0.31 \pm 0.16}$ & $\underline{0.11 \pm 0.07}$ & $\underline{---}$ & $\underline{0.50 \pm 0.12}$ \\
\hline & TMean & $1.74 \mathrm{a} \pm 0.20$ & $0.10 \mathrm{c} \pm 0.10$ & $0 . \overline{70 b \pm 0.20}$ & $0.14 \mathrm{c} \pm 0.06$ & ---- & $0.55 \mathrm{a} \pm 0.08$ \\
\hline \multirow[t]{3}{*}{ Apr. } & $\mathrm{AM}$ & $0.70 \pm 0.21$ & $0.0 \pm 0.0$ & $0.42 \pm 0.28$ & $0.22 \pm 0.09$ & --- & $0.27 \pm 08$ \\
\hline & PM & $\underline{0.62 \pm 0.22}$ & $1.04 * \pm 0.37$ & $\underline{0.42 \pm 0.32}$ & $\underline{0.05 \pm 0.05}$ & $\underline{---}$ & $\underline{0.43 \pm 11}$ \\
\hline & TMean & $0.66 \mathrm{a} \pm 0.13$ & $0.52 \mathrm{ab} \pm 0.21$ & $0.42 \overline{a b c} \pm 0.21$ & $0.14 \mathrm{bc} \pm 0.06$ & --- & $0.35 b \pm 07$ \\
\hline \multirow[t]{3}{*}{ June } & $\mathrm{AM}$ & $1.52 \pm 0.27$ & $0.0 \pm 0.0$ & $0.90 * \pm 0.25$ & $0.29 * \pm 0.10$ & ---- & $0.54 \pm 11$ \\
\hline & PM & $1.35 \pm 0.23$ & $1.33^{*} \pm 0.39$ & $\underline{0.23 \pm 0.23}$ & $\underline{0.06 \pm 0.06}$ & $\underline{----}$ & $0.59 \pm 13$ \\
\hline & TMean & $1.44 \mathrm{a} \pm 0.10$ & $0.67 b \pm 0.23$ & $0.56 b c \pm 0.18$ & $0.18 \mathrm{~cd} \pm 0.06$ & ---- & $0.57 \mathrm{a} \pm 08$ \\
\hline \multirow[t]{3}{*}{ Aug. } & AM & $1.48^{*} \pm 0.29$ & $0.0 \pm 0.0$ & $0.98^{*} \pm 0.32$ & $0.13 \pm 0.09$ & ---- & $0.52 \pm 12$ \\
\hline & PM & $\underline{0.65 \pm 0.25}$ & $3.02 * \pm 0.19$ & $\underline{0.0 \pm 0.0}$ & $\underline{0.0 \pm 0.0}$ & $\cdots$ & $\underline{0.73 \pm 17}$ \\
\hline & TMean & $1.06 \mathrm{a} \pm 0.21$ & $1.51 \mathrm{a} \pm 0.34$ & $0 . \overline{49 b \pm 0.19}$ & $0.06 \mathrm{~b} \pm 0.04$ & ---- & $0.63 \mathrm{a} \pm 10$ \\
\hline \multirow[t]{3}{*}{ Oct. } & $\mathrm{AM}$ & $1.59 * \pm 0.28$ & $0.0 \pm 0.0$ & $0.39 \pm 22$ & $0.05 \pm 0.05$ & ---- & $0.41 \pm 10$ \\
\hline & $\mathrm{PM}$ & $\underline{0.29 \pm 0.17}$ & $2.37 * \pm 0.40$ & $\underline{0.39 \pm 22}$ & $\underline{0.0 \pm 0.0}$ & $\underline{----}$ & $\underline{0.61 \pm 14}$ \\
\hline & TMean & $0.94 \mathrm{a} \pm 0.20$ & $1.19 a \pm 0.30$ & $0 . \overline{39 b \pm 15}$ & $0.03 \mathrm{~b} \pm 0.03$ & ---- & $0.51 \mathrm{ab} \pm 09$ \\
\hline
\end{tabular}

$\mathrm{AF}=$ alkali flats $; \mathrm{FG}=$ floodplain grassland $; \mathrm{SS}=$ shrub savanna; $\mathrm{TS}=$ tree savanna; $\mathrm{WL}=$ woodland.

${ }^{2} \mathrm{AM}=1^{\text {st }} 3$ hours after daylight; $\mathrm{PM}=1^{\mathrm{st}} 3$ hours before dark.

${ }^{3}$ HTMean $=$ Mean for all habitat types per time or month.

${ }^{4}$ Year $=$ Mean for all months per time and per habitat type.

${ }^{5}$ Impala were never observed in the Woodland habitat type at any time during the study.

${ }^{6}$ TMean $=$ Mean for both AM and PM per habitat type or month.

Conversely, impala preference for the shrub savanna tended to be higher in the early-mid wet season than later in the year.

\section{Kudu}

The overall average number of kudu sightings was 0.66 per observation period (Table 5), the highest number for all 5 animals observed. The average number of sightings per month was relatively consistent (i.e., 0.57-0.76). The number of sightings in the morning and afternoon were generally similar each month except for October when more herds of kudu for all habitat types were seen in the morning than in the afternoon.

There were relatively large differences in the average number of sightings of kudu per habitat type, ranging from a high of 1.17 per observation period on the alkali flats down to 0.14 in the woodland habitat type. The average number of sightings per month was relatively consistent on the alkali flats, tree savanna, and woodland, but varied more widely in the shrub savanna and most widely on the floodplain grasslands (0.00 in February during flooding - 1.10 during the late dry season). By mid-late dry season, the number of kudu sightings was very similar on the alkali flats, floodplain grasslands, and shrub savanna - all 3 habitat types next to the Chobe River.

An interaction between habitat type and time of day also influenced the number of sightings of kudu; more kudu herds were seen in the morning than in the afternoon in the shrub savanna and woodland whereas more kudu herds were seen in the afternoon than in the morning on the floodplain grasslands.

Differences in the average number of sightings due to time of day also varied with month of observation within habitat type. The number of kudu sightings on the alkali flats in the morning and afternoon was similar in February and June, slightly greater in the afternoon than in the morning in December and August, much greater in the afternoon in April (i.e., late wet season), and much greater in the morning in October (i.e., late dry season). On the floodplain grasslands, large differ- ences due to time of day in the number of sightings only occurred in April through August, and the number of sightings was always higher in the afternoon. The most consistent effect of time of day on the number of kudu sightings occurred in the tree savanna where kudu were observed more often in the morning during all months of observation except December.

\section{Discussion}

The sighting of relatively numerous herds during February on the alkali flats may have resulted from a prey behavior pattern. Peak growth of both herbaceous and woody vegetation in all habitat types meant that visibility (Montfort 1973) was generally poor during the middle of the wet season. This is particularly important to those species, such as impala and kudu, which easily fall prey to predators (Pienaar 1963, Kingdon 1982). Buffalo fleeing from lion attack (Mills et al. 1995) also usually regrouped on the alkali flats 
Table 5. Numbers (mean \pm SE) of kudu herds observed per time period during different months, times of day, and in different habitat types in Chobe National Park, Botswana. ( $=6 / \mathrm{month} /$ time/habitat type). Means for habitat types for the same time or month followed by a different letter are statistically different at the $5 \%$ level of probability. Significant $(P<0.05)$ differences between means for different times within habitat type and month are indicated by ' $*$ '.

\begin{tabular}{|c|c|c|c|c|c|c|c|}
\hline \multirow[b]{2}{*}{ Month } & \multicolumn{7}{|c|}{ Habitat Type ${ }^{1}$} \\
\hline & Time $^{2}$ & $\mathrm{AF}$ & FG & SS & TS & WL & HTMean $^{3}$ \\
\hline \multirow[t]{3}{*}{$\overline{\text { Year }^{4}}$} & AM & $1.13 \mathrm{a} 5 \pm 0.11$ & $0.28 c \pm 0.09$ & $1.15 a \pm 0.15$ & $0.65 * b \pm 0.08$ & $0.20 * c \pm 0.05$ & $0.68 \pm 0.05$ \\
\hline & PM & $1.20 \mathrm{a} \pm 0.12$ & $1.05 * a \pm 0.16$ & $\underline{0.64 b \pm 0.11}$ & $\underline{0.17 c \pm 0.04}$ & $\underline{0.08 \mathrm{c} \pm 0.03}$ & $0.63 \pm 0.05$ \\
\hline & TMean $^{5}$ & $1.17 \mathrm{a} \pm 0.08$ & $0.67 \mathrm{c} \pm 0.10$ & $0.89 b \pm 0.10$ & $0.41 \mathrm{~d} \pm 0.05$ & $0.14 \mathrm{e} \pm 0.03$ & $0.66 \pm 0.04$ \\
\hline \multirow[t]{3}{*}{ Dec. } & $\mathrm{AM}$ & $1.01 \mathrm{ab} \pm 0.31$ & $0.10 \mathrm{c} \pm 0.10$ & $1.46 \mathrm{a} \pm 0.42$ & $0.58 b c \pm 0.21$ & $0.16 c \pm 0.11$ & $0.66 \pm 13$ \\
\hline & PM & $1.69 \mathrm{a} \pm 0.29$ & $\underline{0.21 b \pm 0.21}$ & $\underline{0.68 b} \pm 0.26$ & $0.35 b \pm 0.16$ & $0.16 \mathrm{~b} \pm 0.11$ & $\underline{0.62 \pm 12}$ \\
\hline & TMean & $1.35 \mathrm{a} \pm 0.22$ & $0.15 b \pm 0.11$ & $1.07 \mathrm{a} \pm 0.26$ & $0.47 b \pm 0.13$ & $0.16 b \pm 0.07$ & $0.64 \pm 09$ \\
\hline \multirow[t]{3}{*}{ Feb. } & $\mathrm{AM}$ & $1.23 a \pm 0.19$ & $0.0 \mathrm{c} \pm 0.0$ & $1.14 \mathrm{a} \pm 0.34$ & $0.70 * a b \pm 0.15$ & $0.22 * b c \pm 0.12$ & $0.67 \pm 10$ \\
\hline & PM & $1.17 \mathrm{a} \pm 0.38$ & $\underline{0.0 \mathrm{c} \pm 0.0}$ & $\underline{0.77 a b \pm 0.23}$ & $\underline{0.27 b c \pm 0.13}$ & $0.15 b c \pm 0.10$ & $0.48 \pm 11$ \\
\hline & TMean & $1.20 \mathrm{a} \pm 0.20$ & $\overline{0.0 \mathrm{c} \pm 0.0}$ & $0.95 \mathrm{a} \pm 0.20$ & $0.49 b \pm 0.11$ & $0.18 b c \pm 0.07$ & $0.57 \pm 07$ \\
\hline \multirow[t]{3}{*}{ Apr. } & $\mathrm{AM}$ & $0.78 a \pm 0.20$ & $0.0 \mathrm{c} \pm 0.0$ & $0.62 a b \pm 0.25$ & $0.59 * a b \pm 0.18$ & $0.22 * b c \pm 0.12$ & $0.44 \pm 0.08$ \\
\hline & PM & $1.64 * a \pm 0.25$ & $1.70 * a \pm 0.36$ & $\underline{0.31 b \pm 0.16}$ & $0.05 b \pm 0.05$ & $0.0 \mathrm{~b} \pm 0.0$ & $0.74 \pm 0.13$ \\
\hline & TMean & $1.21 \mathrm{a} \pm 0 . .18$ & $0.85 a b \pm 0.24$ & $0.47 b c \pm 0.15$ & $0.32 c \pm 0.11$ & $0.11 \mathrm{c} \pm 0.06$ & $0.59 \pm 0.08$ \\
\hline \multirow[t]{3}{*}{ June } & $\mathrm{AM}$ & $1.01 \mathrm{a} \pm 0.25$ & $0.21 b \pm 0.14$ & $1.01 \mathrm{a} \pm 0.41$ & $0.64 * a b \pm 0.20$ & $0.16 b \pm 0.11$ & $0.61 \pm 0.12$ \\
\hline & PM & $1.10 \mathrm{ab} \pm 0.23$ & $1.44 * a \pm 0.40$ & $0.68 b c \pm 0.31$ & $0.12 \mathrm{c} \pm 0.08$ & $\underline{0.0 \mathrm{c} \pm 0.0}$ & $\underline{0.67 \pm 0.13}$ \\
\hline & TMean & $1.06 \mathrm{a} \pm 0.17$ & $\overline{0.82 \mathrm{ab} \pm 0.24}$ & $0.84 a b \pm 0.26$ & $00.38 b c \pm 0.12$ & $0.08 \mathrm{c} \pm 0.05$ & $0.64 \pm 0.09$ \\
\hline \multirow[t]{3}{*}{ Aug. } & $\mathrm{AM}$ & $0.74 b \pm 0.31$ & $0.22 b \pm 0.15$ & $1.60 * a \pm 0.44$ & $0.77 * b \pm 0.24$ & $0.34 * b \pm 0.14$ & $0.73 \pm 0.14$ \\
\hline & PM & $1.38 a \pm 0.37$ & $1.90 * a \pm 0.48$ & $0.49 b \pm 0.33$ & $0.13 b \pm 0.13$ & $0.0 \mathrm{~b} \pm 0.0$ & $0.78 \pm 0.17$ \\
\hline & TMean & $1.06 \mathrm{a} \pm 0.25$ & $1.06 \mathrm{a} \pm 0.31$ & $1.04 a \pm 0.29$ & $0.45 \mathrm{ab} \pm 0.15$ & $0.17 b \pm 0.08$ & $0.76 \pm 0.11$ \\
\hline \multirow[t]{3}{*}{ Oct. } & $\mathrm{AM}$ & $1.88 * a \pm 0.26$ & $1.06 a b \pm 0.36$ & $1.16 a b \pm 0.37$ & $0.60 * b c \pm 0.23$ & $0.14 c \pm 0.09$ & $0.97 * \pm 0.14$ \\
\hline & PM & $\underline{0.36 b c \pm 0.17}$ & $1.14 a \pm 0.40$ & $0.87 \mathrm{ab} \pm 0.34$ & $\underline{0.10 \mathrm{c} \pm 0.07}$ & $\underline{0.14 c \pm 0.09}$ & $0.52 \pm 0.12$ \\
\hline & TMean & $1.12 \mathrm{a} \pm 0.21$ & $1.10 \mathrm{a} \pm 0.26$ & $1.01 \mathrm{a} \pm 0.25$ & $0.35 b \pm 0.13$ & $0.14 b \pm 0.06$ & $0.74 \pm 0.09$ \\
\hline
\end{tabular}

$\mathrm{AF}=$ alkali flats; $\mathrm{FG}=$ floodplain grassland; $\mathrm{SS}=$ shrub savanna; $\mathrm{TS}=$ tree savanna; $\mathrm{WL}=$ woodland.

${ }^{2} \mathrm{AM}=1^{\text {st }} 3$ hours after daylight; $\mathrm{PM}=1^{\text {st }} 3$ hours before dark.

${ }^{3}$ HTMean $=$ Mean for all habitat types per time or month.

${ }_{5}^{4}$ Year $=$ Mean for all months per time and per habitat type.

${ }^{5}$ TMean $=$ Mean for both AM and PM per habitat type or month

because they had a better view of the surrounding cover.

The relatively high numbers of herds during October occurred when available forage mineral supply was low (Bell 1970, Western 1975, McNaughton 1990), and many herds frequented the alkali flats to utilize the mineral licks (Klaus et al. 1998) located in this habitat type. However, the availability of evergreen woody plants, especially Capparis tomentosa Lam., may have also attracted browsers, such as kudu.

The high frequency of sighting herbivores on the floodplains during the dry season marks the importance of the Chobe River as the major contributing source of water for all animals in the study area. Some species, such as kudu and giraffe, which obtain much of their water needs from green leaves (Innis 1958, OwenSmith 1979) during the wet season, frequent the floodplain grasslands during dry season. Other water-dependent species like buffalo (Kingdon 1982, Mugangu et al. 1995), elephant (Laws 1970), and impala (Estes 1991) also use the floodplains during the dry season. Also, ani- mals generally have smaller home ranges with regard to the water sources (Estes 1991, Leuthold 1978) during the dry season and are easier to locate. The few ephemeral pans in the alkali flats, tree savanna, and shrub savanna may meet the water needs of many animals during the rainy season causing them to disperse widely during this season (Jarman 1979, Leuthold 1978, Pellew 1984).

The woodland habitat type had the lowest frequency of observation although it had the most available herbage. Early sprouting of both herbaceous and woody plants from dry season fires were common (Omphile 1997). This habitat type, despite being the greatest distance from the Chobe River, is still within the home ranges of all the study herbivores except the impala (Kingdon 1982). Elephants can cover distances in excess of $40 \mathrm{~km}$ on their daily foraging bouts (Douglas-Hamilton 1972). However, if the animals obtain sufficient forage from other habitat types closer to the river, traveling to the woodland would be a waste of energy. Resident elephant herds remain close to permanent water sources in northern Botswana, but migra- tory herds travel up to $200 \mathrm{~km}$ to reach water in the dry season (Verlinden and Gavor 1998).

The low frequency of sighting of buffalo herds in all habitats may have resulted from simply fewer herds with larger numbers per herd (Omphile 1997) or from their feeding habit described by Kingdon (1982) as "economic feeding" which involves short feeding bouts and longer rests. Buffalo only graze for an average of 9 hours in the 24-hour period, 5 or 6 hours of which are at night. This pattern of feeding allows only 3 to 4 hours of day-time activity, rendering it difficult to sight the animals during day. Winterbach and Bothma (1998), however, noted that buffalo in the South African 'Sourveld' (a suboptimal habitat for buffalo) showed the same circadian rhythm as other ruminants in the area: a few long feeding periods, followed by a few long ruminating and resting periods. Regardless, nighttime grazing was favored during the warmer months, and all drinking occurred during the day.

While the Chobe study area provides a variety of habitat types, it appears the loca- 
tion of the habitat with regard to water is an important element affecting elephant distribution as more bands were frequently sighted on the floodplains and the adjacent alkali flats. Water availability and use of salt licks (Henshaw and Ayeni 1971, Klaus et al. 1998) may also contribute to the preference of these habitat types during the dry season. Elephants were seen picking and eating soil balls in both the floodplains and the alkali flats during the dry season. In addition to providing the major source of water most of the year, the floodplains also provide some green grass during the dry season. Given the low levels of nitrogen and phosphorus observed in elephant dung during the dry season (Omphile 1997), it is not surprising that elephants spent more time where the chance of maximizing nutrient intake was greater.

Despite the woodland being the least preferred by giraffe, the habitat was still within their $12 \mathrm{~km}$ radius home range (Pellew 1984). It was likely that availability of adequate good forage in the other habitats within closer proximity to the Chobe River discouraged frequent use of the distant habitats like the woodlands. The alkali flats provided an abundance of an evergreen woody species Capparis tomentosa Lam., the late dry season blossoming Securinega virosa Roxb., Combretum mossambicense Klotzsch, and the late senescenting Croton megalobostrys. Both the shrub savanna and tree savanna provide the widest choice of browse species in addition to being closer to the river than the woodlands. The floodplains provide water as well as salt licks and adjacent riverine woody species, most of which are green throughout the dry season.

Impala habitat preference in the Chobe National Park reflects certain aspects of this antelope's special requirements which often produce an irregular and clumped distribution. Impala are ecotone species preferring light woodland with sparse undergrowth and grassland of low to medium height (Estes 1991). Also important are soils with free drainage, firm footing, level ground and free water. The 3 most preferred habitat types in this study (alkali flats, floodplains grassland and the shrub savanna) each offer at least 1 of these requirements.

The alkali flats also offer a variety of short grasses and scattered evergreens which impala appear to relish during the dry season. The floodplain is a source of water as well as short to medium height grasses whose dominance appears to be facilitated (McNaughton 1976, Perrin and Brereton-Stiles 1999) by buffalo, and ele- phant during the dry season.

The use of the shrub savanna is probably facilitated by the complementary heavy use of this habitat type by elephants. Heavy use over time shortens the heights of most dominant browse species and reduces canopy cover. However, the reduction of woody plant species does not extend into the adjoining tree savanna which is too densely vegetated and the soil too sandy and loose to make good impala habitat. During the dry season, however, more herds of impala were recorded in the tree savanna when visibility was greater and forage supply elsewhere within impala home range had declined. Even then, impala appeared to concentrate on northern fringes of this habitat type adjacent to the alkali flats and the shrub savanna

Most kudu sightings on the alkali flats, including those seen on the riverine ecotone, were recorded during the dry season when the need for the richest (Fritz et al. 1996, Owen-Smith 1979), but not necessarily the most varied vegetation, was relatively high. While the tree and shrub savannas offer more species of woody plants than the alkali flats, the quality of these species in the dry season has declined. However, kudu herds were seen in both habitats quite frequently during the rainy season indicating wet season preference for these habitats. Kudu sighted on floodplain grassland were either salting or drinking from the river; almost none were seen feeding as browse was limited to areas outside this habitat. In Zambia, kudu rarely entered the Kafue River floodplain during any season (Sheppe and Osborne 1971).

\section{Management Implications}

The greater frequency of sighting herbivores on the floodplain grassland and adjacent alkali flats and shrub savanna as opposed to the more distant habitat types of the tree savanna and woodland implies a disproportionate use of the KasaneNgoma section of the Chobe National Park. Animal concentrations in this area tend to increase competition for limited forage among ungulates with similar diets (Omphile 1997). This disproportionate use can lead to underutilization of some habitat types at the expense of others, a condition that may be driving the public and some special interest groups to suggest that the riverfront area of the park is over-utilized and, therefore, unattractive to tourists.

Our data confirm that tour operators interested primarily in providing their guests with a view of the greatest numbers of animals in a limited period of time are currently justified in congregating on the floodplain grassland in the afternoons during the dry season. However, a more widespread distribution of water and animal herds during the dry season should provide for a lower frequency of tourists seeing other tourist vehicles and, perhaps, a higher quality of wildlife-viewing experience for the Park visitors. As in most public wildlife reserves, Chobe National Park management is faced with the decision of how best to optimize the biological needs of the animals and their habitat with the economic and recreational desires of Park users.

\section{Literature Cited}

Bell, R.H.V. 1970. The use of herb layer by grazing ungulates in the Serengeti. p.111-123. In: A. Watson (ed.). Animal populations in relation to their food resources. Blackwell, London.

Child, G. 1968. An ecological survey of northeastern Botswana. F.A.O. Report T.A. 2563. United Nations, Rome.

Child, G. and W. Von Richter. 1968. Observations on ecology and behavior of linchwe, puku, and waterbuck along the Chobe River, Botswana. Z. Sangetierk. 34:275-295.

Dekker, B., N. van Rooyen, and J.D. Bothma. 1996. Habitat partitioning by ungulates on a game ranch in the Mopani veld. S. Afr. J. Wildl. Res. 26 117-122.

Douglas-Hamilton, I. 1972. On the ecology and behaviour of the African elephant. The elephants of Lake Manyara. D. Phil. Thesis, Oxford Univ.

Estes, R.D. 1991. The behavior guide to African mammals. Univ. Calif. Press, Los Angeles, Calif..

Field, D. 1978. Basic ecology for range management in Botswana. Min. of Agr., Gaborone.

FGU. Undated. Chobe National Park - a description of the resource. (Botswana Dept. Nat. Parks and Wildl. Mimeo.)

Fritz, H., M. de Garine-Wichatitsky, and G. Letessier. 1996. Habitat use by sympatric wild and domestic herbivores in an African savanna woodland: The influence of cattle spatial behaviour. J. Appl. Ecol. 33 589-598.

Henshaw, J. and J. Ayeni. 1971. Some aspects of big game utilization of mineral licks in Yankari Game Reserve, Nigeria. E. Afr. Wildl. J. 9:73-82.

Henry, F.W.T. 1966. Enumeration report on the Chobe main forest. Min. of Agr., Gaborone.

Innis, A. 1958. The behavior of the giraffe (Giraffa camelopardalis) in the eastern Transvaal. Proc. Zool. Soc. Lond. 35:129-146.

Jarman M.V. 1979. Impala social behavior. Beihefte Z. Tierpsychol. 21:1-92.

Kingdon, J. 1982. East. African mammals: an atlas of evolution in Africa. Vol. 3 part C (Bovids). Academic Press, New York. 
Klaus, G., C. Klaus-Hugi, and B. Schmid. 1998. Geophagy by large mammals at natural licks in the rain forest of the Dzanga National Park, Central African Republic. J. Trop. Ecol. 14 829-839.

Laws, R.M. 1970. Elephants as agents of habitat and landscape change in East Africa. Oikos 21:1-15.

Leuthold, B.M. 1978. Day time activity pattern of gerenuk and giraffe in Tsavo National Park, Kenya. E. Afr. Wildl. J. 16:129-141.

McNaughton, S.J. 1976. Serengeti migratory wildebeest: facilitation of energy flow by grazing. Science 191:92-94.

McNaughton, S.J. 1990. Mineral nutrition and seasonal movements of African migratory ungulates. Nature 345:6113-6115.

McNeeley, J.A. 1988. Economics and biological diversity: developing and using economic incentives to conserve biological resources. Int. Union Conserv. Nature Nat. Resources, Gland, Switzerland.

Miller, O.B. 1939. The mukusi forests of Bechuanaland. Emp. For. J.18:193-201.

Mills, M.G.L., H.C. Biggs, and I.J. Whyte. 1995. The relationship between rainfall, lion predation and population trends in African herbivores. Wildl. Res. 22 75-87.
Montfort, A. 1973. Notes sur l'ecologie et le comportement des oribis (Qurebia qurebi, Zimmermann 1783). Terre el Vie. 28:169, 208.

Mugangu, T.E., M.L. Hunter, and J.R. Gilbert. 1995. Food, water, and predation: A study of habitat selection by buffalo in Virunga National Park, Zaire. Mammalia 59 349-362.

Omphile, U.J. 1997. Seasonal diets, diet quality and habitat preference of large, savanna ungulates in the Chobe National Park, Botswana. Ph.D. Dissertation, Univ. Wyo. Laramie, Wyo.

Owen-Smith, N. 1979. Assessing the foraging efficiency of a large herbivore, the kudu. S Afr. J. Wildl. Res. 9:102-110.

Pienaar, U. de V. 1963. Large mammals of the Krueger National Park - their distribution and present day status. Koedoe 6:1-37.

Pellew, R.A. 1984. The feeding ecology of a selective browser, the giraffe (Giraffa camelopardalis). J. Zool. Lond. 202:57-81.

Perrin, M.R. and R. Brereton-Stiles. 1999. Habitat use and feeding behaviour of the buffalo and the white rhinoceros in the Hluhluwe-Umfolozi Game Reserve. S. Afr. J. Wildl. Res. 29:72-80.
SAS. 1985. SAS user's guide. Version 6 ed SAS Institute Inc. Raleigh, N. C..

Selous, F.C. 1881. A hunter's wanderings in Africa. London.

Sheppe, W. and T. Osborne. 1971. Patterns of use of a flood plain by Zambian mammals. Ecol. Monogr. 41:179-205.

Steel, R.G.D. and J.H. Torrie. 1980. Principles and procedures of statistics. $2^{\text {nd }}$ ed. McGrawHill Book Co., Inc. New York, N. Y.

Verlinden, A. and I.K.N. Gavor. 1998. Satellite tracking of elephants in northern Botswana. Afr. J. Ecol. 36 105-116.

Western, D. 1975. Water availability and its influence on the structure and dynamics of a savanna large mammal community. E. Afr. Wildl. J. 13:265-286.

Winterbach, H.E.K. and J.D. Bothma. 1998. Activity patterns of the Cape buffalo Syncerus caffer caffer in the Willem Pretorius Game Reserve, Free State. S. Afr. J. Wildl. Res. 28:73-81. 


\title{
Plains larkspur (Delphinium geyeri) grazing by cattle in Wyoming
}

\author{
JAMES A. PFISTER, DALE R. GARDNER, BRYAN L. STEGELMEIER, ANTHONY P. KNIGHT, JAMES W. \\ WAGGONER, JR., AND JEFFERY O. HALL
}

Pfister, Gardner and Stegelmeier are Rangeland Scientist, Research Chemist, and Veterinary Pathologist, respectively, USDA-ARS Poisonous Plant Research Lab., 1150 E. 1400 N., Logan, Ut. 84341; Knight is Dept. Head, Veterinary Clinical Science, Colorado State Univ., Ft. Collins, Colo; Waggoner is Associate Professor, Dept. of Renewable Resources, University of Wyoming, Laramie, Wyo.; Hall is Veterinary Toxicologist, Dept. of Animal, Dairy, and Vet. Sci., Utah State University, Logan, Ut. 84322. Pfister's email is jpfister@cc.usu.edu.

\section{Abstract}

Plains larkspur (Delphinium geyeri Greene) is a major cause of cattle deaths in the northern Great Plains of Wyoming and Colorado. We examined the amount and timing of larkspur ingestion by grazing cattle in relation to larkspur phenology, nutrient concentrations, and weather conditions. Four summer grazing trials were conducted near Cheyenne (1996 and 1997) and Laramie, Wyo. (1998 and 1999). All trials began when plains larkspur was vegetative or in the early bud stage. In the first 2 studies, 6 yearling heifers grazed from 3 May to 4 August 1996; the same animals plus $5 \mathrm{cow}$-calf pairs grazed from 13 May to 10 August 1997. During both 1996 and 1997, cattle ate 0.5 to $1 \%$ of bites as larkspur during May, then consumption decreased to nearly 0 during the remainder of both summers. When eaten, larkspur was typically consumed during cool, foggy weather conditions. In the last 2 studies, 6 cow-calf pairs grazed near Laramie, Wyo., from 13 May to 30 June 1998, and 6 different cow-calf pairs grazed from 2 June to 20 July 1999. Cattle ate substantial amounts of plains larkspur (herd average $\sim 3 \%$ ) during the vegetative and bud stages from mid-May into early June, 1998. Cattle may have eaten more larkspur during 1998 because drought reduced spring availability of green grass. Consumption of larkspur was negatively related $\left(r^{2}=0.43\right)$ to daily temperature in 1998, but not during 1999. During 1999 cattle ate essentially no plains larkspur during the vegetative and bud stages, but ate larkspur (herd average $\sim 5 \%$ ) during the flower and pod stages when larkspur plants were beginning to desiccate and ambient temperatures were above average. This series of trials indicates that it will be difficult to predict plains larkspur consumption based on larkspur growth patterns or weather. Although cattle sometimes increase plains larkspur consumption when temperatures are cooler than normal, this pattern is not consistent enough to serve as a basis for management recommendations.

Key Words: toxic plants, diet selection, cattle grazing, methyllycaconitine, alkaloids

The authors wish to thank Kermit Price, Dirk Salmon, Dr. Mike Smith, Dr Mike Ralphs, Lee Woolsey, Jeff Salmon, Al Maciulis, Rex Probst, Danny Hansen, Jason Dormady, and Rick Shea for assistance with various aspects of the study. We appreciate the generous cooperation provided by Jerry Johnson and Mike McGraw, Belvoir Ranch, Cheyenne, Wyoming, and Andy and Mark Johnson, Johnson Ranch, Laramie, Wyoming.

Manuscript accepted 24 Oct. 2001

\section{Resumen}

El "Plains larkspur" (Delphinium geyeri Greene) es la principal causa de muerte de ganado en las Grandes Planicies del norte de Wyoming y Colorado. Examinamos la cantidad y tiempo de ingestión de "Larkspur" por el ganado en apacentamiento en relación a la fenología del "Larkspur", la concentración de nutrientes y las condiciones climáticas. Se condujeron cuatro ensayos de apacentamiento de verano cerca de Cheyenne (1996 y 1997) y Laramie (1998 y 1999). Todos los ensayos iniciaron cuando el "Plains larkspur"estaba en etapa vegetativa o inicios de brotación de yemas. En los primeros dos estudios, 6 vaquillas de un año apacentaron del 3 de mayo al 4 de agosto de 1996; los mismos animales mas 5 pares de vaca-becerro apacentaron del 13 de mayo al 10 de agosto de 1997. En Mayo de ambos años, 1996 y 1997, del 0.5 a $1 \%$ de las mordidas del ganado fueron de “Larkspur", después, en el resto del verano, el consumo decreció a casi cero. Cuando el "Larkspur" fue consumido típicamente ocurrió cuando el clima era frío y neblinoso. En los últimos dos estudios 6 pares de vaca-becerro apacentaron cerca de Laramie, Wyoming del 13 de mayo al 30 de junio de 1998 y 6 pares de vaca-becerro diferentes apacentaron del 2 de junio al 20 de julio de 1999. Durante las etapas vegetativa e inicio de brotación de yemas, de mediados de mayo a inicios de junio de 1998, el ganado comió cantidades substanciales de "Plains larkspur" (promedio del hato $\sim 3 \%$ ). El ganado pudo haber comido mas 'Larkspur'durante 1998 porque la sequía redujo la disponibilidad de forraje verde en primavera. En 1998, el consumo de "Larkspur" fue relacionado negativamente $\left(r^{2}=0.43\right)$ con la temperatura diaria, pero esto no sucedió en 1999. Durante 1999 el ganado esencialmente no comió "Plains larkspur" durante las etapas vegetativas e inicio de brotación de yemas, pero comió "Larkspur" durante los estados de floración y fructificación (promedio del hato $\sim 5 \%$ ) cuando las plantas de "larkspur" comenzaron a desecarse y las temperaturas ambiente estuvieron arriba del promedio. Esta serie de estudios indica que basados en los patrones de crecimiento o clima será difícil predecir el consumo de "Plains larkspur". Aunque el ganado algunas veces incrementa el consumo de "Plains larkspur" cuando las temperaturas son mas frías de lo normal, este patrón no es lo suficientemente consistente para servir como base para recomendaciones de manejo. 
Plains larkspur (Delphinium geyeri Greene) is a major cause of cattle poisoning in the northern Great Plains of Wyoming and Colorado (Chesnut 1898, Beath 1919, 1925). The perennial larkspur typically begins growth in spring before grasses and other forbs have begun growth, and thus may offer green forage while grasses are dormant (Chesnut 1898). Plains larkspur contains numerous diterpenoid alkaloids, but the principal toxins are methyllycaconitine (MLA) and nudicauline (Manners et al. 1995).

No grazing studies have examined cattle consumption of plains larkspur. The objective of this study was to evaluate the amount and timing of larkspur consumption by cattle in relation to its phenology, toxicity, and other potentially important variables such as weather.

\section{Materials and Methods}

\section{Cheyenne 1996 and 1997}

Two trials were conducted during 1996 and 1997 on the Belvoir Ranch about 15 $\mathrm{km}$ west of Cheyenne, Wyo. (41 ${ }^{\circ} 5.40^{\prime} \mathrm{N}$ $105^{\circ} 0.31^{\prime} \mathrm{W} ; 2,026 \mathrm{~m}$ elevation). Western wheatgrass (Pascopyrum smithii [Rydb.] A. Love) and blue grama (Bouteloua gracilis [H.B.K.] Lag. ex Steud.) were the dominant constituents of the vegetation on the mixed grass prairie site; plains larkspur was a major forb.

Forage availability was determined at the beginning and end of the grazing trials by clipping $30,0.25 \mathrm{~m}^{2}$ quadrats placed along 2 pace transects through the pasture. Clipped samples were placed into paper bags, and oven-dried at $60^{\circ} \mathrm{C}$ to a constant weight. Density of plains larkspur was determined by counting the number of larkspur plants in $300,0.25 \mathrm{~m}^{2}$ quadrats placed systematically along 3 pace transects.

Larkspur phenology was assessed by marking 30 plants just outside the study pasture, and weekly observations were made on each plant. Larkspur plants were collected weekly for toxic alkaloid and nutrient analysis (see below). Twenty larkspur plants at each phenological stage were harvested and composited by growth stage. These weekly samples were frozen in plastic bags, freeze-dried, ground through a 1-mm screen, then analyzed for concentrations of toxic alkaloids by electrospray mass spectrometry (Gardner et al. 1999).

Grass samples for nutrient analysis were clipped weekly from five, $0.25 \mathrm{~m}^{2}$ plots in 5 representative areas of the pasture, oven dried at $40^{\circ} \mathrm{C}$ to a constant weight, then ground to pass a $1-\mathrm{mm}$ screen in a Cyclone grinder. Grass and larkspur samples were composited for each week, and then analyzed for neutral detergent fiber (NDF) using dacron bags in a modification of the Van Soest et al. (1991) method. Plant tissue was extracted with boiling neutral detergent using filter bags in a batch fiber analyzer (ANKOM, Fairport, N.Y.). An elemental analyzer (NA 2100 Protein Nitrogen Analyzer, ThermoQuest Italia S.p.A., Milan, Italy) was used to determine nitrogen content, and crude protein content was calculated (AOAC 1990).

Grass and larkspur samples were also analyzed for micronutrient concentrations using Inductively Coupled Plasma Mass Spectroscopy (ICP-MS). Plant tissue was digested via a modification of EPA method 3050 (Smith 1994). Digestions were performed in screw-cap teflon tubes, using $0.5 \mathrm{~g}$ of ground plant material in 10 $\mathrm{ml}$ of trace metal grade nitric acid at $90^{\circ} \mathrm{C}$ for 2 hours. The plant digests were diluted with $18.3 \mathrm{ml}$ of ultrapure water to $5 \%$ nitric acid prior to analysis. Standard curves for each element consisted of 5 concentrations between 10 and 2,500 ng $\mathrm{ml}^{-1}$. Quality control checks and standard curves were analyzed every 5 samples.

A moderate stocking rate was used during all trials. Six yearling heifers $(305 \mathrm{~kg})$ grazed from 3 May to 4 August 1996 on the 15 ha pasture. Heifers had not been previously exposed to larkspur. The trial began when plains larkspur was 3 to $6 \mathrm{~cm}$ tall (i.e., vegetative). The trial was divided into 4 periods corresponding to larkspur phenology: vegetative ( 3 to 16 May), vegetative/bud (17 May to 7 June), bud/early flower (8 June to 11 July), and flower/pod (12 July to 4 August). During 1997, 5 of the same heifers (then 2 years old) grazed the study site, plus an additional 5 cowcalf pairs that had no previous experience with plains larkspur. Cattle grazed from 13 May to 10 Aug 1997, and the study pasture was enlarged to 24 ha. The trial was divided into 4 periods corresponding to larkspur growth: vegetative (13 to 24 May), vegetative/bud (26 May to 25 June), flower (26 June to $10 \mathrm{July}$ ), and late flower/pod (11 July to 10 August). Trace mineral blocks were offered free choice during this and all subsequent trials.

Daily bite counts were used to determine animal diets (Pfister et al. 1997b). Beginning at 0700 hours every day, individual animals were focally sampled (Altmann 1974) in a predetermined random order. Each animal was observed in turn for 5 minutes. After all animals had been observed, the process was repeated during all active grazing periods until about 1900 hours, when cattle were placed in a corral for the night. Bites were categorized as grasses, other forbs, and larkspur bud, flower, pod, leaf, leaf and stem, or whole plant. We defined an individual bite as a single cropping motion, always indicated by a head jerk, often accompanied by a visible sweep of the tongue, and independent of chewing motions.

Weather variables (temperature, barometric pressure, relative humidity, wind speed and direction, precipitation) were monitored on site during the grazing studies using an automated weather station (Campbell Scientific, Logan, Ut.). Climatology information was supplemented using data from the Cheyenne airport located $18 \mathrm{~km}$ from the study site.

\section{Laramie 1998 and 1999}

Two trials were conducted on the Laramie Plains about $10 \mathrm{~km}$ southwest of Laramie, Wyo. (41 ${ }^{\circ} 17.19^{\prime} \mathrm{N} 105^{\circ} 43.83^{\prime}$ W; 2,225 m elevation). Larkspur density, phenology, and alkaloid concentration were determined as detailed above. Forage availability and nutrient status was determined by clipping weekly and handling the samples as noted above, except that grass samples for nutrient analysis were inadvertently discarded in 1998 . Forbs were generally a minor component in the vegetation each year, except for 1999. Because of a tremendous growth of Drummond's milkvetch (Astragalus drummondii Dougl. ex. Hook.) on the site during 1999, we sampled milkvetch and other forbs in addition to grasses and larkspur. We separated dry and green grass in 1998, but did not in 1999 as drought and grazing the previous year greatly reduced the amount of residual dry grass on the study site.

During 1998, 6 cow-calf pairs grazed on the 16 ha pasture from 13 May to 30 June. Based on larkspur phenology, the 48-day trial was divided into 4 periods corresponding to vegetative/early bud (14 to 25 May), bud stage (26 May to 6 June), late bud/early flower with most plants green ( 7 to 18 June), and late bud/flower with most plants becoming desiccated (19 to 30 June). During 1999 the pasture was enlarged to 20 ha, and was grazed by 6 different cow-calf pairs from 2 June to 20 July. Based on larkspur phenology in 1999, the trial was divided into 3 periods: vegetative/early bud (2 June to 11 June); bud/early flower (12 June to 2 July); flower/early pod (3 July to 20 July). As far as we know, larkspur was a novel food for all animals at the beginning of each summer's trial near Laramie. During 1998 and 1999 , bite counts began at dawn (0500 to 
0520 hours) each day and continued during active grazing periods until about 1800 hours. The cattle were placed into a corral each evening and group-fed $600 \mathrm{~g} \mathrm{head}^{-1}$ of a mix of rolled barley and melengesterol acetate $\left(550 \mathrm{mg} \mathrm{cow}^{-1}\right.$ day $\left.^{-1}\right)$ to prevent estrus and avoid interference from bulls grazing the adjoining pasture.

Weather variables were measured using an automated weather station as noted previously. Climatology information was supplemented using data from the Laramie airport located $7 \mathrm{~km}$ east of the study site.

\section{Statistical Analysis}

Bite count data were analyzed using the GLM procedure of SAS (1998). Each year was analyzed separately, with animals considered as blocks, and periods as treatments, with repeated measurements over days within periods. Stepwise multiple regression was used to examine relationships between larkspur consumption (the dependent variable) and weather and forage nutrient variables. Larkspur consumption in relation to weather was examined in 12 and 24 hour blocks. Mineral values for plants were averaged by weeks to provide a monthly mean. Regression analysis to relate forage nutrient (i.e., mineral, NDF, and crude protein) concentrations were done using weekly averages for larkspur consumption. No statistical analysis was done on weekly protein, NDF, or alkaloid concentrations from the composited samples.

\section{Results}

\section{Cheyenne 1996 and 1997 \\ Weather}

Average daily temperatures were close to normal during 1996 and from May to August 1997, but were colder than normal during April 1997 (Fig. 1). Summer precipitation was near or exceeded normal amounts during both years (Fig. 1). Summer forage production is highly correlated with precipitation during March, April and early May (Rauzi 1964, Hart and Samuel 1985), and during both years precipitation during those months was close to normal.

\section{Forage Availability}

About $80 \%$ of the available forage was grass during the 2 trials near Cheyenne, with plains larkspur comprising about 6 to $12 \%$ of the standing crop (Table 1). In general, forbs other than larkspur were a minor component of the standing crop in the pasture.
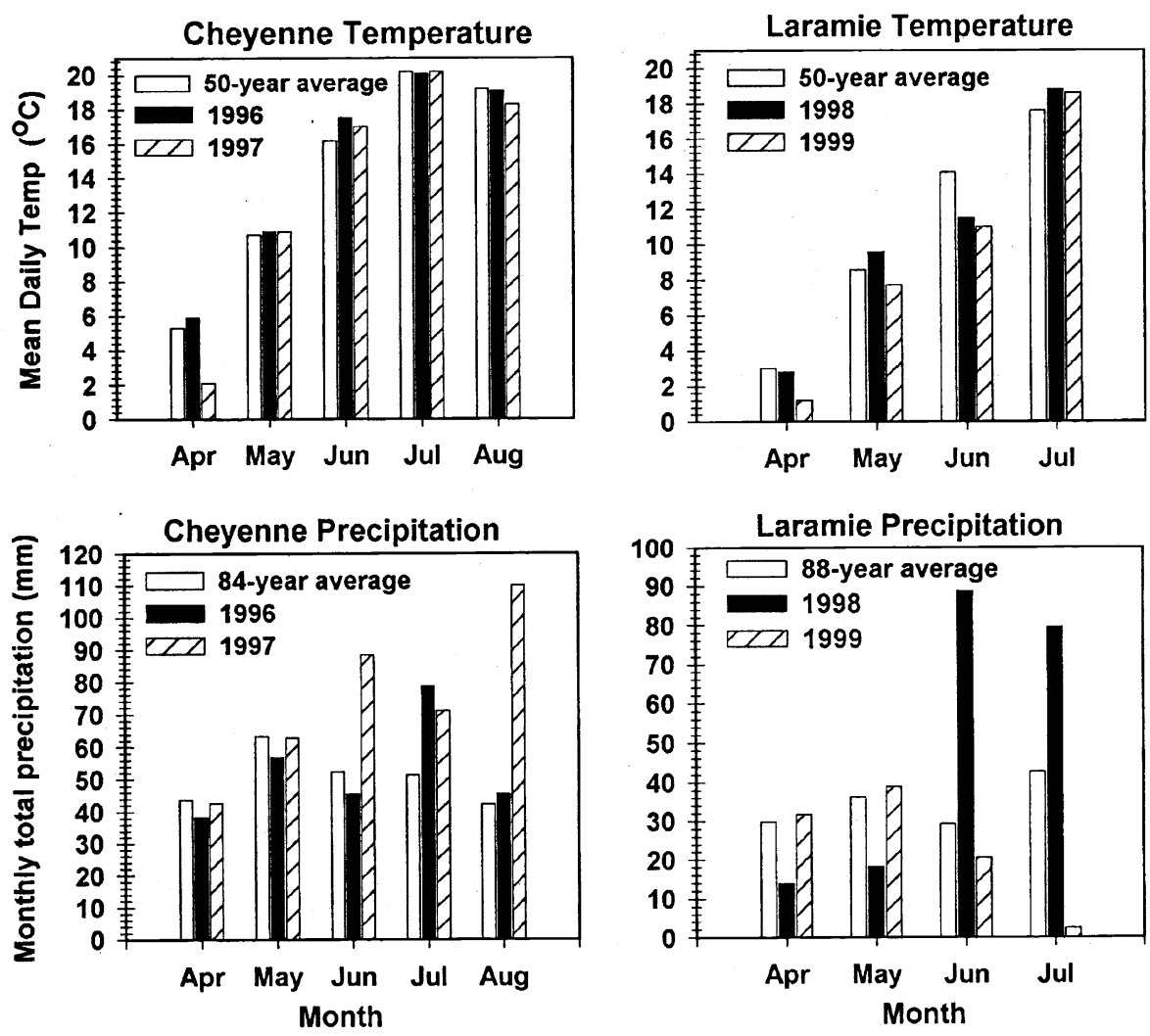

Fig. 1. Temperature (monthly average in degrees $\mathrm{C}$ ) and precipitation (monthly total in $\mathrm{mm}$ ) during spring and summer grazing trials for Cheyenne (1996 and 1997) and Laramie, Wyo. (1998 and 1999).

\section{Larkspur Density, Phenology and Alkaloid Concentration}

Larkspur density was 2.4 and 2.2 plants $\mathrm{m}^{-2}$ during 1996 and 1997, respectively. All larkspur plants were vegetative when the grazing study began in early May each year (Fig. 2). During 1996 larkspur growth was diverse, with some plants maturing while others were emerging. Most larkspur plants were fully mature or dead by late July, 1996. Growth was initially slower and more uniform during 1997, but in late June larkspur plants quickly began flowering. These flowering plants were slow to produce pods, and many larkspur plants senesced during mid-to-late July, 1997.

Plains larkspur plants during 1996 were highly toxic ( $>6 \mathrm{mg}$ toxic alkaloid $\mathrm{g}^{-1}$ plant dry matter) early in the vegetative stage (Table 2), and remained moderately toxic (3-6 $\mathrm{mg} \mathrm{g}^{-1}$ ) until mid July when they were in the late flower or pod stages of growth. Larkspur plants showed similar patterns during 1997, except that vegetative plants were not as high in alkaloid concentrations as in 1996, and concentrations remained moderately toxic ( $>3 \mathrm{mg}$ $\mathrm{g}^{-1}$ ) even when plants were largely senescent in early August (Fig. 2).

\section{Cattle Diets}

Cattle ate about $1 \%$ of bites as larkspur during May 1996, then consumption decreased to nearly 0 in June. Cattle ate essentially no larkspur during the last 2 months of the study during 1996 (data not shown), and periods did not differ ( $\mathrm{P}>$ 0.10). Over the entire 1996 trial, grasses and other forbs comprised 91.7 and $8.0 \%$ of bites, respectively. The only day of substantial larkspur consumption was 17 May 1996, a hot (maximum temperature $30^{\circ} \mathrm{C}$ ) and windy day. Two cows ate up to $30 \%$ of their bites as larkspur leaves and stems during several grazing bouts, and one was visibly intoxicated during the afternoon. Visible signs included staggering gait, muscular tremors, and periodic sternal recumbency.

Larkspur consumption was very low $(<$ $0.2 \%$ of bites) during all periods in 1997 , and periods did not differ $(\mathrm{P}>0.10)$ On 2 cold, damp days (19 and 21 May 1997) 2 cows ate $>15 \%$ of bites as larkspur in the morning, but showed no signs of intoxication. Nonetheless, there was no relationship $P>0.1$ ) between weather variables and larkspur consumption. Cattle diets were primarily grasses $(93.5 \%)$ and other forbs $(>6 \%)$ during the 1997 trial. 
Table 1. Standing crop $\left(\mathrm{kg} \mathrm{ha}^{-1}+\mathrm{SE}\right)$ during plains larkspur grazing trials during summer, 1996 and 1997 (Cheyenne), and 1998 and 1999 ( Laramie), Wyo.

\begin{tabular}{lcc}
\hline \hline Forage Class & \multicolumn{3}{c}{ Sample Period } \\
\hline 3 May-4 August 1996 & Begin & End \\
Grass & $663 \pm 96$ & $511 \pm 63$ \\
Forbs & $47 \pm 15$ & $100 \pm 25$ \\
Larkspur & $47 \pm 11$ & $68 \pm 12$ \\
& & \\
12 May-10 August 1997 & $322 \pm 38$ & $364 \pm 44$ \\
Grass & $36 \pm 10$ & $90 \pm 54$ \\
Forbs & $49 \pm 14$ & $63 \pm 28$ \\
Larkspur & & \\
& $37 \pm 5$ & $15 \pm 6$ \\
13 May-30 June 1998 & $125 \pm 9$ & $157 \pm 11$ \\
Dry grass & $97 \pm 11$ & $38 \pm 6$ \\
Green grass & $60 \pm 13$ & $3 \pm 2$ \\
Forbs & & \\
Larkspur & $178 \pm 14$ & $163 \pm 16$ \\
1 June-20 July 1999 & $28 \pm 17$ & $17 \pm 5$ \\
Grass & $89 \pm 18$ & $63 \pm 20$ \\
Forbs & $32 \pm 12$ & $8 \pm 3$ \\
Larkspur & & \\
Milkvetch (Astragalus drummondii) & & \\
\hline
\end{tabular}

\section{Nutrient Content of Forage}

We found no relationships between nutrient or mineral content of the forage and larkspur consumption. Plains larkspur averaged more than $13 \%$ crude protein during 1996, while grasses averaged $9 \%$ crude protein, but by the end of the study both plant types contained about $8 \%$ crude protein. Conversely, grasses contained more than $66 \% \mathrm{NDF}$, whereas larkspur averaged 34\% NDF (Fig. 3). During 1997 larkspur averaged $12 \%$ crude protein compared to $10 \%$ for grasses, but grasses and larkspur had similar crude protein concentrations after May 1997. Grasses had NDF concentrations of $61 \%$ while larkspur averaged 34\% NDF (Fig. 3).

Both larkspur and grasses were highest in mineral concentrations when immature, and concentrations decreased with maturity (Table 3). Larkspurs generally exceeded grass as a source of calcium, phosphorus, potassium, and magnesium. Both larkspur and grasses were low in copper and sodium, and had marginally low concentrations of zinc and manganese. Cobalt, molybdenum, iron and selenium concentrations were adequate during each month (data not shown for $\mathrm{Fe}$ and $\mathrm{Se}$ ).

\section{Laramie 1998 and 1999}

\section{Weather}

Average ambient temperatures were at or above normal during spring, 1998, but June 1998 was cooler than normal (Fig. 1). Conversely, precipitation was lower than normal during April and May, 1998, but

ncreased to above normal amounts during June 1998 (Fig. 1). During 1999, temperapotent alkaloid in plains larkspurs, were very low. tures were cooler than normal until July 1999 , while precipitation was at or slightly above normal in April and May 1999, then falling below normal levels in June and July 1999.

\section{Forage availability}

Forage growth was delayed by drought in spring, 1998. Grasses made up more than $50 \%$ of the standing crop, and most of the grasses had begun green growth in mid-May 1998 (Table 1). During 1999, forage growth was delayed by colder than normal weather even though precipitation was adequate, and the 1999 grazing trial started almost 3 weeks later than did the 1998 trial at the same location. When the study began, most grasses had initiated green growth, as had Drummond's milkvetch.

\section{Larkspur Density, Phenology, and Alkaloid Concentration}

Larkspur density averaged 1.7 and 1.9 plants $\mathrm{m}^{-2}$ during 1998 and 1999, respectively. The drought during 1998 retarded the development of larkspur plants, as

Table 2. Toxic alkaloid concentrationa ( $\mathrm{mg}$ toxic alkaloid $\mathrm{g}^{-1}$ plant dry matter) of plains larkspur (Delphinium geyeri) during summer grazing studies near Cheyenne, Wyo. during 1996 and 1997.

\begin{tabular}{|c|c|c|c|c|}
\hline \multirow[b]{2}{*}{$\begin{array}{l}\text { Phenological } \\
\text { Stage }\end{array}$} & \multicolumn{2}{|c|}{1996} & \multicolumn{2}{|c|}{1997} \\
\hline & Date & $\begin{array}{l}\text { Toxic alkaloid } \\
\text { Concentration }\end{array}$ & Date & $\begin{array}{l}\text { Toxic alkaloid } \\
\text { Concentration }\end{array}$ \\
\hline Vegetative & $\begin{array}{l}\text { 3 May } \\
10 \text { May } \\
17 \text { May } \\
24 \text { May } \\
\text { 31 May } \\
7 \text { June } \\
\text { 14 June } \\
28 \text { June } \\
5 \text { July }\end{array}$ & $\begin{array}{c}--\left(\mathrm{mg} \mathrm{g}^{-1}\right)-- \\
7.0 \\
5.1 \\
4.9 \\
3.9 \\
4.1 \\
3.3 \\
3.2 \\
2.1 \\
1.4\end{array}$ & $\begin{array}{r}14 \text { May } \\
21 \text { May } \\
28 \text { May } \\
4 \text { June }\end{array}$ & $\begin{array}{c}-\left(\mathrm{mg} \mathrm{g}^{-1}\right)-- \\
4.7 \\
3.9 \\
3.0 \\
2.6\end{array}$ \\
\hline Bud & $\begin{array}{l}\text { 31 May } \\
7 \text { June } \\
14 \text { June } \\
21 \text { June } \\
28 \text { June } \\
5 \text { July }\end{array}$ & $\begin{array}{l}3.9 \\
3.2 \\
3.8 \\
3.6 \\
3.5 \\
3.0\end{array}$ & $\begin{array}{l}4 \text { June } \\
11 \text { June } \\
17 \text { June } \\
25 \text { June } \\
1 \text { July }\end{array}$ & $\begin{array}{l}3.0 \\
2.8 \\
3.4 \\
2.7 \\
2.4\end{array}$ \\
\hline Flower & $\begin{array}{l}14 \text { June } \\
21 \text { June } \\
28 \text { June } \\
5 \text { July } \\
12 \text { July } \\
10 \text { July } \\
26 \text { July }\end{array}$ & $\begin{array}{l}3.6 \\
3.4 \\
3.3 \\
3.5 \\
2.8 \\
2.8 \\
1.8\end{array}$ & $\begin{array}{l}1 \text { July } \\
9 \text { July } \\
16 \text { July }\end{array}$ & $\begin{array}{l}4.2 \\
3.0 \\
2.6\end{array}$ \\
\hline Pod & $\begin{array}{l}12 \text { July } \\
19 \text { July } \\
26 \text { July } \\
2 \text { August }\end{array}$ & $\begin{array}{l}4.0 \\
2.6 \\
2.4 \\
2.1\end{array}$ & $\begin{array}{l}23 \text { July } \\
31 \text { July } \\
6 \text { August }\end{array}$ & $\begin{array}{l}4.0 \\
3.9 \\
4.0\end{array}$ \\
\hline
\end{tabular}

${ }^{a}$ Larkspur samples were composites of twenty individual plants. Toxic alkaloid concentrations indicate the amount of MSAL-type alkaloids, of which methyllycaconitine (MLA) is the dominant alkaloid. Concentrations of nudicauline, a 

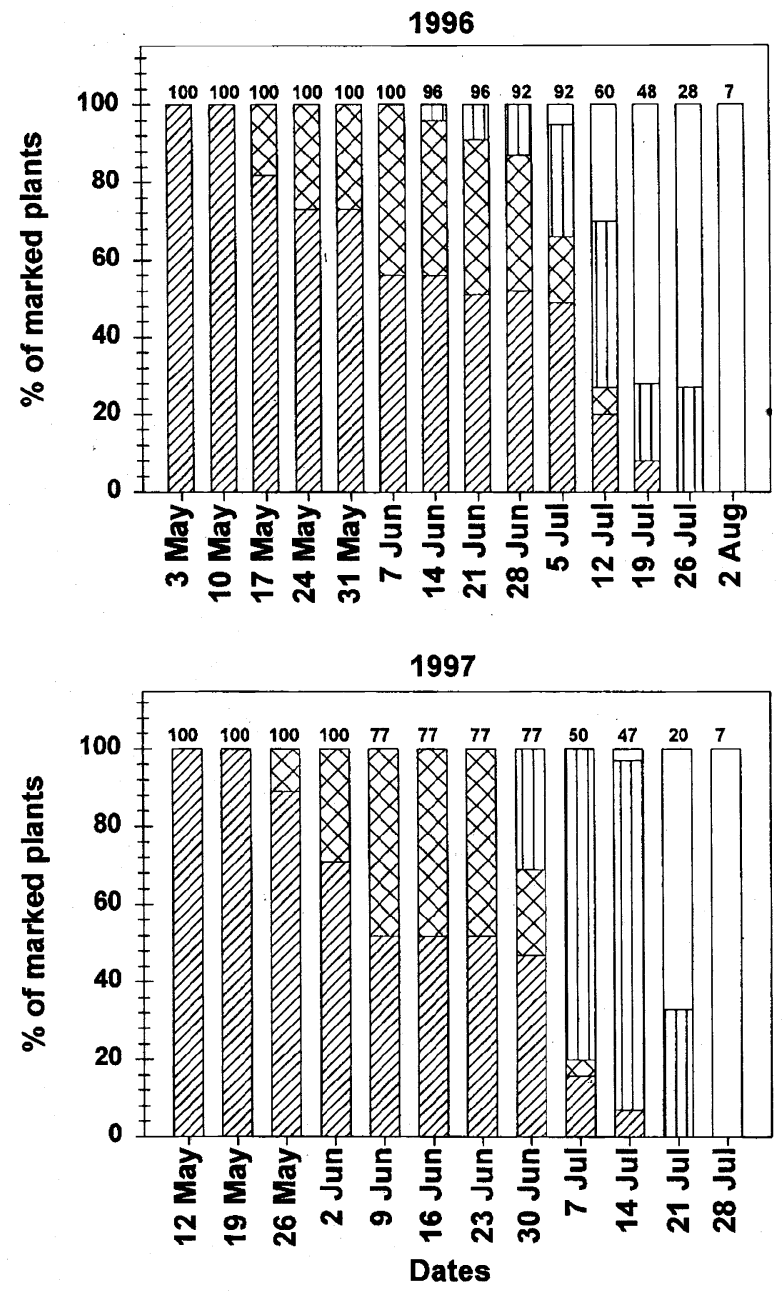

एयु Vegetative $\square \times$ Bud $[1]$ Flower $\square$ Pod

Fig. 2. Proportions (\% of marked plants) of plains larkspur (Delphinium geyeri) in various phenological growth stages during summer, 1996 and 1997, near Cheyenne, Wyo. Thirty plants were marked during each year. The number on top of each bar represents the percentage of marked plants still alive when the observations were taken.

most died before flowering (Fig. 4). In addition, larkspur plants appeared to be shorter than normal although we did not measure height. Larkspur growth was delayed during May 1999 from colder than normal temperatures, and most plants were vegetative or in the bud stage when the trial began in early June. Dry conditions during June and July also hampered the development of larkspur plants, and most dried out in early July without producing pods.

Plains larkspur plants were moderately high $\left(>5 \mathrm{mg} \mathrm{g}^{-1}\right)$ in toxic alkaloid concentration at the beginning of the trials in both 1998 and 1999. Toxic alkaloid concentrations remained relatively stable (about 3 to $4 \mathrm{mg} \mathrm{g}^{-1}$ ) throughout both grazing trials (Table 4). Drummond's milkvetch contained very low concentrations $(<0.1 \%)$ of the indolizidine alkaloid, swainsonine (Gardner, unpublished data). consumption during 1998, but not 1999, was negatively related $\left(r^{2}=0.43\right)$ to maximum and minimum daily temperature. The regression equation relating temperature to larkspur consumption was $\mathrm{y}=12.4$ $-0.16 \mathrm{x}-0.09 \mathrm{z}$, where $\mathrm{y}$ is larkspur consumption, $\mathrm{x}$ is minimum daily temperature (degree $\mathrm{C}$ ) and $\mathrm{z}$ is maximum daily temperature.

Larkspur averaged $<0.01,0.9$ and $4.8 \%$ of bites $(\mathrm{P}<0.05)$ for the 3 periods in 1999 corresponding to early, mid-, and late-maturity for larkspur, respectively (Fig. 5). Grasses comprised 96, 88, and $82 \%$ of bites during periods 1 to 3 , respectively, during 1999. Cattle ate substantial amounts (7 to 10\% of bites) of Drummond's milkvetch during periods 2 and 3 , whereas consumption of other forbs (exclusive of larkspur and milkvetch) did not exceed 5\% of bites in any period.

\section{Nutrient Content of Forage}

Plains larkspur averaged $12 \%$ and $32 \%$ crude protein and NDF, respectively, during 1998 (Fig. 3). During 1999 larkspur averaged $9.5 \%$ crude protein compared to $9.8 \%$ for grasses. The crude protein content of plains larkspur was negatively related to weekly larkspur consumption $\left(\mathrm{r}^{2}\right.$ $=0.51$ ) during 1999 as cattle ate more larkspur when plants were maturing (Fig. 5). Grasses had NDF concentrations of 59\% while larkspur averaged 33\% NDF during 1999. Drummond's milkvetch and other forbs had higher crude protein concentrations and similar NDF concentrations compared to the other forage types.

All measured mineral elements except $\mathrm{Zn}$ increased in plains larkspur from June to July, 1998 (Table 5). Larkspur plants increased mineral concentrations greatly (except for $\mathrm{Zn}$ ) from the June to July, 1998 sampling periods. None of the different forage types contained adequate $\mathrm{Na}$ concentrations for lactating cattle (NRC 1996); except for forbs, all forage types were also inadequate in Mn concentration. Grasses were low in both $\mathrm{P}$ and $\mathrm{Zn}$ in June and July 1999. Furthermore, weekly larkspur consumption during both 1998 and 1999 was related to $\mathrm{Zn}$ concentration in plains larkspur $\left(r^{2}=0.58\right.$ and 0.79 , respectively). No other mineral variables were related to larkspur consumption ( $\mathrm{P}>$ 0.15 ).

\section{Discussion}

bouts where larkspur exceeded 15-20\% of bites, and numerous animals were visibly intoxicated (i.e., staggering and sternal recumbency). No animals were fatally intoxicated during the study. Larkspur 
Table 3. Mineral concentration ( $\mathrm{mg} \mathrm{kg}^{-1}$ ) of plains larkspur and grasses during summer, 1996-1997 near Cheyenne, Wyo.

\begin{tabular}{|c|c|c|c|c|c|c|c|c|}
\hline \multirow[b]{2}{*}{ Element $^{\mathrm{a}}$} & \multicolumn{2}{|c|}{ May } & \multicolumn{2}{|c|}{ June } & \multicolumn{2}{|c|}{ July } & \multicolumn{2}{|c|}{ August } \\
\hline & Larkspur & Grass & Larkspur & Grass & Larkspur & Grass & Larkspur & Grass \\
\hline & & & & & $\begin{array}{c}1996 \\
\left(\mathrm{mg} \mathrm{kg}^{-1}\right)-\end{array}$ & & & \\
\hline $\mathrm{Ca}$ & 16895.5 & 2959.7 & 21865.6 & 2853.6 & 22204.5 & 3424.8 & 19506.7 & 4022.6 \\
\hline K & 37255.1 & 11488.2 & 27198.4 & 11611.8 & 19740.7 & 8569.7 & 15839.0 & 8053.8 \\
\hline $\mathrm{Mg}$ & 2760.5 & 565.7 & 2209.4 & 623.1 & 2197.3 & 611.9 & 1733.4 & 649.0 \\
\hline $\mathrm{Na}$ & 25.2 & 22.0 & 21.8 & 11.4 & 24.6 & 10.7 & 42.4 & 6.2 \\
\hline $\mathrm{Cu}$ & 9.5 & 3.7 & 6.6 & 4.0 & 4.3 & 2.9 & 3.1 & 2.6 \\
\hline Co & 0.08 & 0.07 & 0.08 & 0.04 & 0.07 & 0.06 & 0.05 & 0.05 \\
\hline $\mathrm{Mn}$ & 43.9 & 31.0 & 29.2 & 23.6 & 17.7 & 18.6 & 11.6 & 22.2 \\
\hline Mo & 1.2 & 1.4 & 1.6 & 1.8 & 1.5 & 1.7 & 0.7 & 1.8 \\
\hline $\mathrm{P}$ & 3377.0 & 1877.9 & 2341.2 & 1932.2 & 1894.5 & 1348.6 & 1724.9 & 1120.4 \\
\hline \multirow[t]{2}{*}{$\mathrm{Zn}$} & 26.9 & 16.9 & 22.2 & 15.6 & 18.9 & 12.6 & 17.6 & 12.3 \\
\hline & & & & & $\begin{array}{c}1997 \\
\left(\mathrm{mg} \mathrm{kg}^{-1}\right)-\end{array}$ & & & . - - \\
\hline $\mathrm{Ca}$ & 17566.1 & 3374.1 & 18480.7 & 3197.2 & 18323.2 & 3542.5 & 2914.1 & 3148.2 \\
\hline K & 37086.8 & 13593.9 & 25306.6 & 15481.7 & 15503.3 & 12121.7 & 911.4 & 8556.6 \\
\hline $\mathrm{Mg}$ & 2971.7 & 683.0 & 1964.8 & 765.1 & 1416.5 & 666.9 & 230.1 & 632.1 \\
\hline $\mathrm{Na}$ & 151.7 & 14.9 & 134.4 & 12.8 & 127.9 & 21.7 & 3.9 & 42.4 \\
\hline $\mathrm{Cu}$ & 7.8 & 4.3 & 7.0 & 4.3 & 5.9 & 3.5 & 0.7 & 5.6 \\
\hline Co & 0.07 & 0.07 & 0.09 & 0.04 & 0.49 & 0.04 & 0.03 & 0.04 \\
\hline $\mathrm{Mn}$ & 34.7 & 28.2 & 35.3 & 27.9 & 20.7 & 19.6 & 2.3 & 26.4 \\
\hline Mo & 0.6 & 1.6 & 1.1 & 1.3 & 1.4 & 1.6 & 0.4 & 1.2 \\
\hline $\mathrm{P}$ & 3334.9 & 2103.6 & 3530.4 & 2507.6 & 2258.5 & 1700.5 & 253.2 & 1671.1 \\
\hline $\mathrm{Zn}$ & 22.3 & 34.3 & 24.1 & 20.1 & 176.4 & 14.9 & 10.3 & 15.6 \\
\hline
\end{tabular}

${ }^{\mathrm{a}}$ Requirements $\left(\mathrm{mg} \mathrm{kg}^{-1}\right)$ of mature beef cow during early lactation: $\mathrm{Ca}-3400 ; \mathrm{K}-8000 ; \mathrm{Mg}-2000 ; \mathrm{Na}-1000 ; \mathrm{Cu}-10 ; \mathrm{Co}-0.1 ; \mathrm{Mn}-40 ; \mathrm{Mo}-<5 ; \mathrm{P}-2400 ; \mathrm{Zn}-30 . \mathrm{Source}$ : NRC (1996).

during brief periods in May of each year. Those brief periods were (with one major exception on 17 May 1996) characterized by cool, foggy weather conditions. Even so, cattle were very inconsistent and ate no larkspur on many damp, cool days. The very low consumption of plains larkspur in the Cheyenne grazing trials was unexpected because plains larkspur populations were abundant and livestock losses are common in this area (A.P. Knight, personal communication). Nonetheless, reported livestock losses were few during the spring and summer of both 1996 and 1997. We are aware of fewer than 10 reported cattle deaths during both summers in the Cheyenne area. Larkspur was not highly toxic during most of both summers (i.e., $<4 \mathrm{mg} \mathrm{g}^{-1}$ of toxic alkaloid), and we surmise that consumption of larkspur in our grazing trials mirrored trends in the local cattle herds.

We have no plausible explanation for the low consumption during the 2 summers in Cheyenne. The Cheyenne site had abundant grass each year, and most of the cattle diets were composed of grasses. Local ranchers believe that cattle tend to eat more plains larkspur early in the season when plains larkspur has initiated growth, but grasses lag behind in green growth. Even though we began the studies in May each year when plains larkspur was only $3-6 \mathrm{~cm}$ tall, cattle ate little or no larkspur during these times. Ranchers also have suggested that cattle eat plains larkspur during flowering, but consumption was essentially 0 during flowering at the Cheyenne site. The study was not designed to compare larkspur consumption at Cheyenne and Laramie, and any comparisons are confounded over time. Even so, availability of grasses was higher at Cheyenne than at Laramie, and this may have influenced cattle consumption of plains larkspur. In contrast, cattle ate most

larkspur in Laramie during early July 1999, when grass was relatively abundant and availability of the most preferred forb, Drummond's milkvetch, was greatly reduced by grazing.

In previous work we have shown that alkaloid (Pfister et al. 1996) or carbohydrate (Ralphs, unpublished data) concentrations have little impact on consumption of tall larkspurs by cattle. In some summers cattle have eaten low amounts of tall

Table 4. Toxic alkaloid concentrationa (mg toxic alkaloid $\mathrm{g}^{-1}$ plant dry matter) of plains larkspur (Delphinium geyeri) during summer grazing studies near Laramie, Wyo. during 1998 and 1999.

\begin{tabular}{|c|c|c|c|c|}
\hline \multirow[b]{2}{*}{$\begin{array}{l}\text { Phenological } \\
\text { Stage }\end{array}$} & \multicolumn{2}{|c|}{1998} & \multicolumn{2}{|c|}{1999} \\
\hline & Date & $\begin{array}{l}\text { Toxic alkaloid } \\
\text { Concentration }\end{array}$ & Date & $\begin{array}{l}\text { Toxic alkaloid } \\
\text { Concentration }\end{array}$ \\
\hline Vegetative & $\begin{array}{l}16 \text { May } \\
23 \text { May } \\
30 \text { May }\end{array}$ & $\begin{array}{c}-\left(\mathrm{mg} \mathrm{g}^{-1}\right)-- \\
5.4 \\
4.7 \\
4.1\end{array}$ & $\begin{array}{l}2 \text { June } \\
12 \text { June }\end{array}$ & $\begin{array}{c}-\left(\mathrm{mg} \mathrm{g}^{-1}\right)-- \\
5.1 \\
4.7\end{array}$ \\
\hline Bud & $\begin{array}{l}5 \text { June } \\
13 \text { June } \\
20 \text { June }\end{array}$ & $\begin{array}{l}3.9 \\
3.6 \\
4.2\end{array}$ & $\begin{array}{l}2 \text { June } \\
12 \text { June } \\
18 \text { June }\end{array}$ & $\begin{array}{l}4.3 \\
4.2 \\
4.3\end{array}$ \\
\hline Flower & 27 June & 4.3 & $\begin{array}{l}18 \text { June } \\
25 \text { June } \\
3 \text { July }\end{array}$ & $\begin{array}{l}3.6 \\
4.5 \\
4.5\end{array}$ \\
\hline Pod & - & - & $\begin{array}{l}9 \text { July } \\
16 \text { July }\end{array}$ & $\begin{array}{l}3.5 \\
3.8\end{array}$ \\
\hline
\end{tabular}

${ }^{a}$ Larkspur samples were composites of twenty individual plants. Toxic alkaloid concentrations indicate the amount of MSAL-type alkaloids, of which methyllycaconitine (MLA) is the dominant alkaloid. Concentrations of nudicauline, a potent alkaloid in plains larkspurs, were very low. Larkspur plants did not produce pods during the drought of 1998 . 

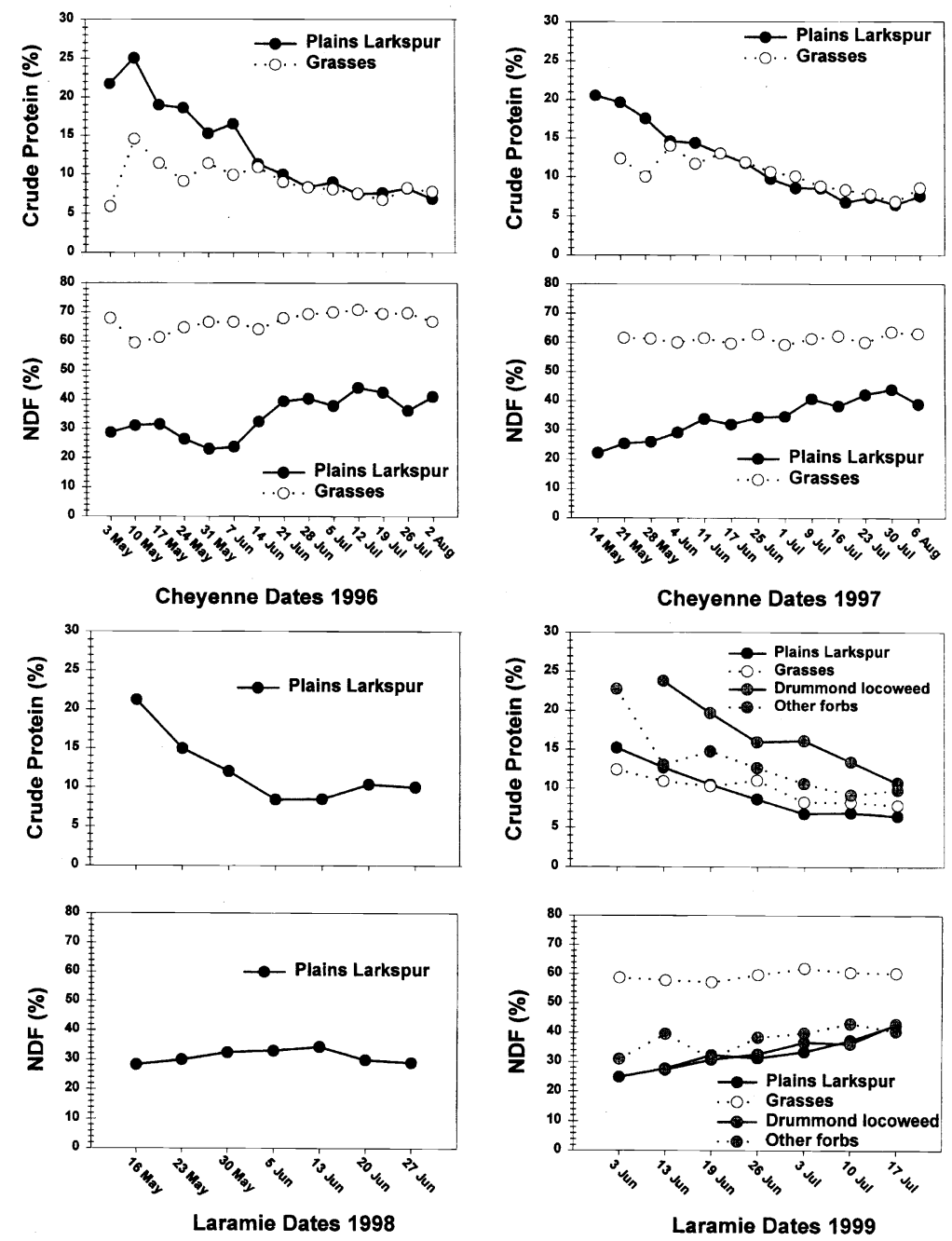

Fig. 3. Crude protein and NDF (\% of dry matter) concentrations in weekly composited forage samples from grazing studies in Cheyenne and Laramie, Wyo. during the summers of 1996, 1997, 1998, and 1999.
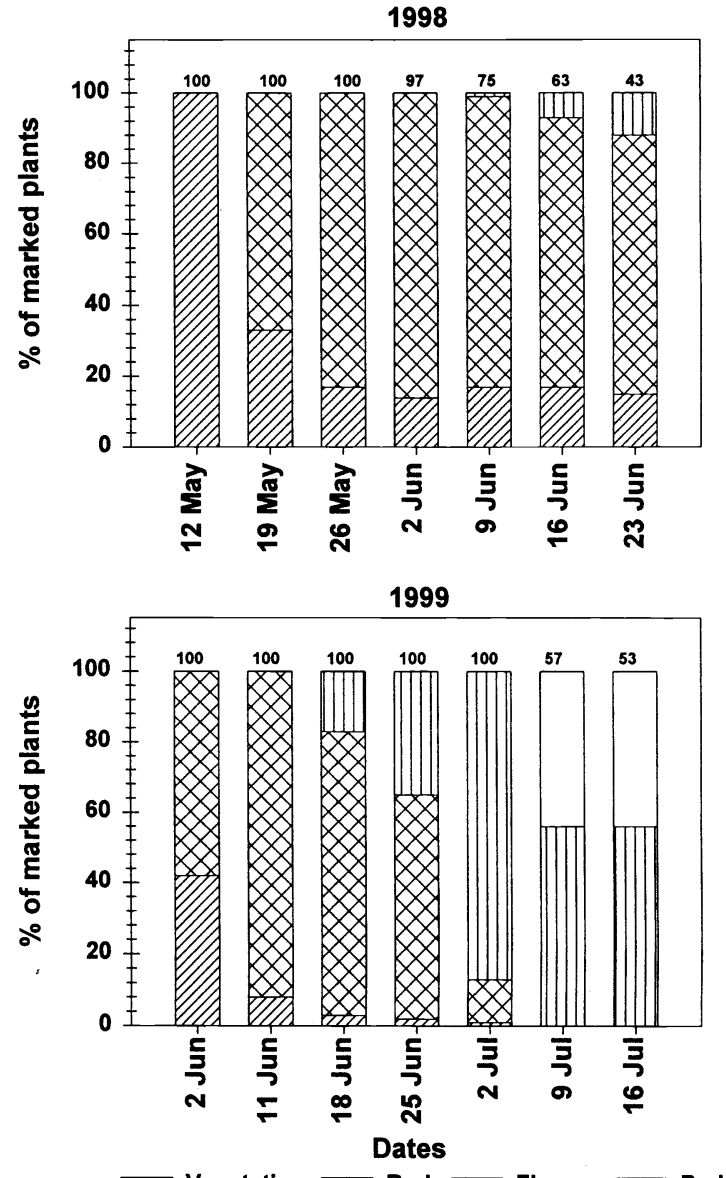

एय] Vegetative खx Bud 피 Flower $\square$ Pod

Fig. 4. Proportions (\% of marked plants) of plains larkspur (Delphinium geyeri) in various phenological growth stages during summer, 1998 and 1999, near Laramie, Wyoming. Thirty plants were marked during each year. The number on top of each bar represents the percentage of marked plants still alive when the observations were taken. larkspurs (Pfister et al. 1999), and we have attributed these patterns to summer drought (Pfister and Manners 1991, 1995). Unlike tall larkspurs, there was no indication that consumption of plains larkspur was reduced during drought except that limited moisture at Laramie in 1998 reduced plains larkspur phytomass and hence availability to grazing animals.

Different larkspur consumption patterns emerged in the Laramie grazing studies. During 1998, cattle ate substantial amounts of plains larkspur during the vegetative and bud stages from mid-May into early June. The drought during spring 1998, severely retarded growth of both larkspur and grasses; plains larkspur never recovered from this lack of initial moisture and much of the shorter-than-normal larkspur in the pasture had either been grazed or was desiccated and dead when the study ended. Cattle may have eaten more larkspur in response to the reduced availability of green grass early in the grazing season. On the contrary, during 1999 cattle ate essentially no plains larkspur during the vegetative and bud stages, but ate most larkspur during the flower and pod stages. The study pasture had adequate spring (i.e., April and May) moisture during 1999 , but received lower than normal precipitation during June and July.

Cattle had somewhat different daily eating patterns during the 2 summer trials in Laramie. Cattle ate larkspur at various times throughout the day in 1998, but particularly at times when cooler temperatures prevailed. Damp, cold, and fog seemed to be associated with plains larkspur consumption for reasons that are not clear. We have noted in other studies that cattle avidly eat other larkspur species during cooler and wetter periods (Pfister et al. 1988, Ralphs et al. 1994). Even though the early summer of 1999 was colder than normal, we did not find a relationship between temperature and larkspur consumption, as cattle ate little larkspur during the cooler period. Most larkspur consumption occurred during early July when larkspur plants were beginning to dry out and average daily temperatures were at or above normal.

Larkspur consumption averaged over groups of animals does not clearly show trends by individual animals (Pfister et al. 1997a). We consolidated larkspur selection data for each animal from 3 consecutive observation periods, termed here as a grazing bout, when larkspur consumption was highest during each day. Individual maxima clearly highlight the periods of greatest consumption in Laramie during 
Table 5. Mineral concentration ( $\mathrm{mg} \mathrm{k}^{-1}$ ) of plains larkspur and grasses during summer, 1998-1999 near Laramie, Wyoming.

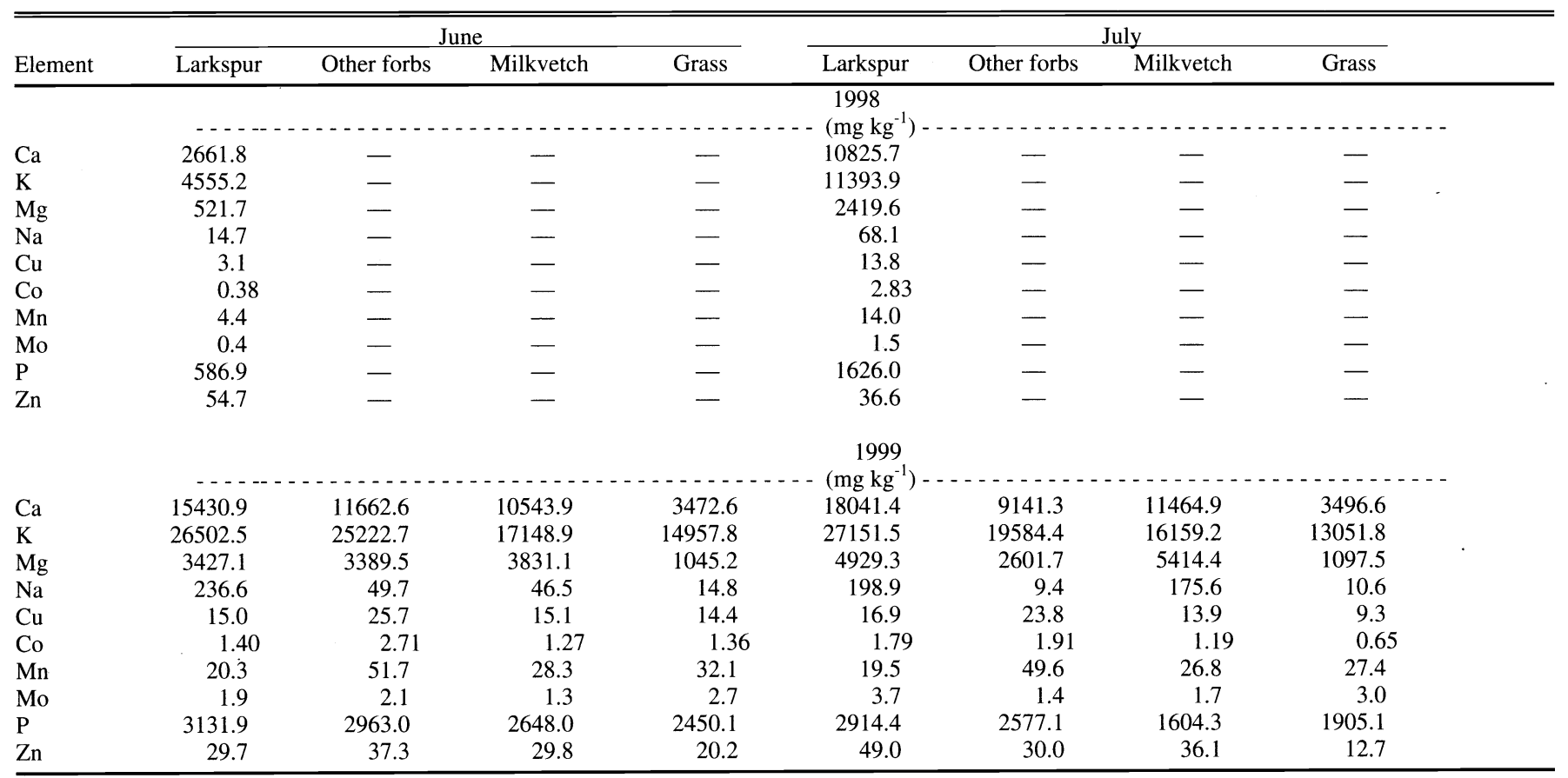

1998 and 1999 (Fig. 5). Larkspur consumption by individual animals often exceeded $20 \%$ of their diet during these grazing bouts, and in some cases exceeded $50 \%$ of bites. We have shown in other work that cattle consume tall larkspur in a cyclic fashion, with days of higher consumption followed by a detoxification period and lower consumption for 1 or 2 days (Pfister et al. 1997a). Cattle in the Laramie grazing studies followed a similar cyclic pattern. It was particularly noteworthy that larkspur consumption sufficient to cause temporary intoxication (i.e., short term paralysis and recumbency) was usually followed by very low consumption for 1 or 2 days.

We periodically monitored calves for diet selection for 2 or 3 minutes for each observation, although total grazing activity by calves was sporadic and often of short duration. Calves in all the grazing studies appeared to graze larkspur in concert with their adult cohorts. Calves ate essentially no larkspur in Cheyenne, whereas consumption in the Laramie trials was sometimes very high ( $>50 \%$ of bites) for brief periods. We speculate that consumption as calves predisposes these individuals to greater acceptability of larkspur in future years, as noted by studies on other plants (Distel and Provenza 1991, Distel et al. 1996), but we have not tested this notion.

\section{Larkspur Consumption and Forage Nutrient Concentration}

One commonly recommended means to reduce larkspur losses is through mineral supplementation (Hughes 1941, Logan 1973, Knowles 1974). Anecdotal accounts suggest that dicalcium phosphate is often supplemented in hopes of reducing larkspur consumption by cattle. Larkspur is an excellent source of $\mathrm{Ca}$, generally far exceeding the $3,000 \mathrm{mg} \mathrm{kg}^{-1}$ requirement for lactating animals; grasses also often exceeded this required amount of $\mathrm{Ca}$.

The forage $\mathrm{P}$ requirement for early lactating cows is $1900 \mathrm{mg} \mathrm{kg}^{-1}$ (forage dry wt., NRC 1996), and larkspur often exceeded this amount whereas grasses were sometimes deficient (Tables 3 and 5). Cattle ate substantial amounts of larkspur in late May and early June 1998 when plains larkspur had low P concentrations. During a period of major larkspur consumption in July 1999, grasses and larkspur both met or exceeded $\mathrm{P}$ requirements.

The ideal $\mathrm{Ca}: \mathrm{P}$ ratio is $1: 1$ but not greater than 7:1 (NRC 1996); the ratio in larkspur was 9.3, 7.5, 5.6 and 5.6 in 1996 to 1999 , respectively. The Ca:P ratio in grasses was generally 1.5 to 1.7 (Tables 3 and 5). Cattle ate little or no larkspur when the Ca:P ratio was highest in 1996 and 1997, suggesting that high Ca concentrations in larkspur do not promote increased consumption, at least in cows that are grazing grasses with an adequate $\mathrm{Ca}: \mathrm{P}$ ratio. It is possible that $\mathrm{Ca}$-deficient cows might eat more Ca-rich larkspur, but it doesn't appear that grasses in this region are deficient in $\mathrm{Ca}$ during early to midsummer.

As expected, the forage in all 4 years was deficient in $\mathrm{Na}$. Both grasses and larkspur were deficient in $\mathrm{Cu}$ (i.e, $<10 \mathrm{mg} \mathrm{kg}^{-1}$ ) at the Cheyenne site during both summers, but $\mathrm{Cu}$ concentrations were adequate in both grasses and larkspur during 1999 in Laramie. Zinc was the only mineral element in larkspur that was related to consumption, and this relationship was observed during both 1998 and 1999 in Laramie. Zinc concentrations were generally inadequate $\left(<30 \mathrm{mg} \mathrm{kg}{ }^{-1}\right)$ in forage from Cheyenne; except for grasses, forages in Laramie contained adequate $\mathrm{Zn}$ concentrations. Because other forages in Laramie also contained adequate zinc concentrations, it is not clear if the association between zinc concentration and larkspur consumption is biologically significant.

Plains larkspur was generally higher in protein than were grasses early in the growing season, but differences were usually minor after larkspur matured. Crude protein concentration of larkspur in Laramie during 1999 was negatively related to larkspur consumption because cattle ate more larkspur when larkspur was maturing and nitrogen concentrations were declining. We doubt if crude protein concentration had any real effect on larkspur consumption. 

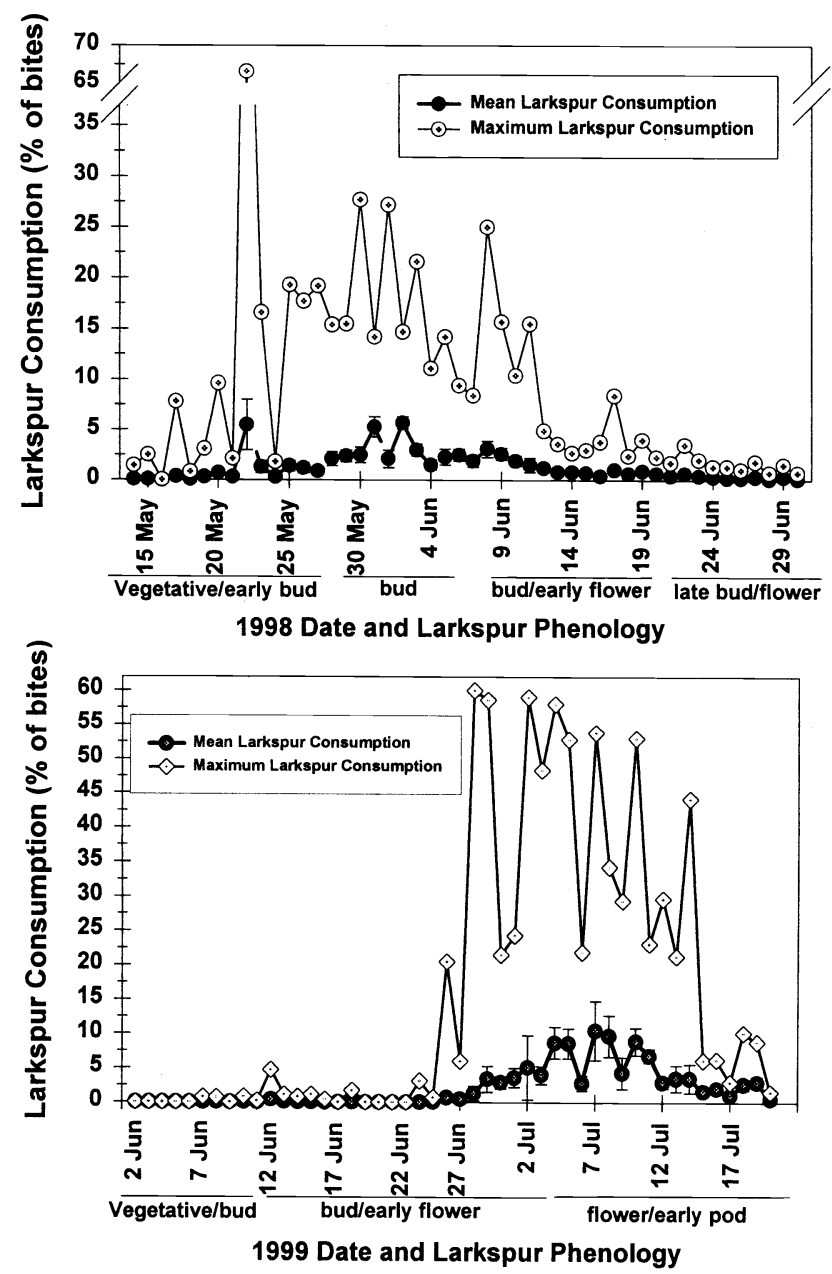

Fig. 5. Larkspur consumption (\% of bites) by cattle during spring and summer, 1998 to 1999, near Laramie, Wyo. Mean larkspur consumption reflects mean consumption by all experimental cows. Maxima reflect larkspur consumption data that were consolidated for each experimental animal from 3 consecutive observation periods, termed here as a grazing bout, when larkspur consumption was highest during each day. Only the single highest daily maximum from among all grazing animals (i.e., one animal) is shown.

Results for protein and NDF are typical of comparisons between forbs and grasses (Cook and Harris 1968, Abouguendia 1998, Perez Corona et al. 1998). Taken together, there was little evidence that consumption (or lack thereof) of larkspur was driven by mineral or nutrient concentrations. As with tall larkspurs, we recommend that livestock producers make supplementation decisions based on forage deficiencies and cattle nutrient requirements, but not as a basis for altering consumption of larkspur by cattle (Pfister and Manners 1991, 1995).

\section{Toxicity of Plains Larkspur}

No toxicology studies have established the threshold of toxicity for plains larkspur in cattle. Therefore we estimated the amount of larkspur that constituted a toxic dose of plains larkspur. Grazing cattle often displayed signs of larkspur toxicosis during May and early June 1998, and early July 1999 , as on many occasions cattle were temporarily paralyzed and unable to walk or stand. We did not treat any intoxicated animals, although at times we were uncertain if the affected cattle would survive (none died). Affected cattle averaged $5 \%$ of total daily bites $(\mathrm{n}=24, \overline{\mathrm{x}}=5.1, \mathrm{SD}$ $=2.6$ ) as plains larkspur on days when overt toxicity was noted. Cattle had total biting rates of about 45 bites minute ${ }^{-1}$. Individual larkspur plants weighed 1.5 to 2 g plant $^{-1}$ (dry wt.) and cattle generally ingested most or all of one larkspur plant bite $^{-1}$ (Pfister unpublished data). Thus, on a typical day $(\sim 10$ hours of actual grazing time) during this period cattle ingested about 1,350 bites of larkspur day ${ }^{-1}$ or 2.0 to $2.7 \mathrm{~kg}$ of larkspur day ${ }^{-1}$. We note that larkspur consumption is typically not steady during the day, but cattle often have grazing bouts when much of the diet consists of larkspur. Larkspur during this period averaged about 4 to $5 \mathrm{mg}$ toxic alkaloid $\mathrm{g}^{-1}$ dry wt. (Table 4), thus cattle were ingesting about 8.1 to $13.5 \mathrm{~g} \mathrm{day}^{-1}$ of alkaloid. A toxic, but not fatal, dose of tall larkspur alkaloids in cattle is $21 \mathrm{mg} \mathrm{kg}^{-1}$ body weight (Pfister et al. 1994). For cattle weighing $500 \mathrm{~kg}$, the $21 \mathrm{mg} \mathrm{kg}^{-1}$ value indicates a toxic alkaloid dose of about $10.5 \mathrm{~g}$. From these calculations it appears that plains larkspur has similar or perhaps slightly greater toxicity than tall larkspurs. Interestingly, we did not observe as many cases of overt intoxication during 1999 as during 1998, even though cattle ate more larkspur at times during 1999. Toxic alkaloid concentrations were similar, and differences in eating patterns may have been responsible. As previously noted, during 1998 cattle ate larkspur steadily throughout the day, whereas consumption in 1999 was characterized by more rapid consumption during fewer grazing bouts. Both sets of experimental animals were lactating, but during 1998 the cows were in a lower body condition than during 1999. Lower body condition may alter the absorption and elimination patterns of toxic alkaloids (Lopez and Launchbaugh, unpublished data), thus rendering thin animals more susceptible to intoxication.

\section{Conclusions}

This series of trials suggests that it will be difficult to predict plains larkspur consumption based on larkspur growth patterns, nutrient concentrations, or weather. As with tall larkspurs, cattle sometimes increased plains larkspur consumption when temperatures were cooler than normal. Nonetheless, this pattern was not consistent and therefore will not serve as a basis for management recommendations that can reduce risk and losses. Currently, our best management recommendation is to ensure that other desirable forage production is ample when cattle graze in plains larkspur-infested pastures. Extra caution may be warranted if cattle are in low body condition. Additionally, if losses persist from year-to-year, the flat terrain in many areas may provide an opportunity to use tractor-mounted herbicidal control to reduce dense larkspur patches. Whitson et al. (1992) has shown that herbicidal control of plains larkspurs can effectively reduce dense populations. 


\section{Literature Cited}

Abouguendia, Z. 1998. Seasonal pattern of nutrient content of native plants: an overview. The Grazing Gazette, Vol. 7, No.1, Grazing and Pasture Tech. Prog., Regina, Sask., Can.

Altmann, J. 1974. Observational study of behavior: sampling methods. Behav. 49:227-267.

AOAC. 1990. Official Methods of Analysis $\left(15^{\text {th }}\right.$ Ed.). Assoc. of Official Analytical Chemists, Washington, D.C.

Beath, O.A. 1919. The chemical examination of three species of larkspurs. Univ. Wyoming Agr. Exp. Sta. Bull. 120.

Beath, O.A. 1925. Chemical examination of three Delphiniums. Univ. Wyoming Agr. Exp. Sta. Bull. 143.

Chesnut, V.K. 1898. Thirty poisonous plants of the United States. USDA Farmers Bull. 86.

Cook, C.W. and L.E. Harris. 1968. Nutritive value of seasonal ranges. Utah Agr. Exp. Sta. Bull. 472.

Distel, R.A. and F.D. Provenza. 1991. Experience early in life affects voluntary intake of blackbrush by goats. J. Chem. Ecol. 17:431-449.

Distel, R.A., J.J. Villalba, H.E Laborde, and M.A. Burgos. 1996. Persistence of the effects of early experience on consumption of low-quality roughage by sheep. J. Anim. Sci. 74:965-968.

Gardner, D.R., K.E. Panter, J.A. Pfister, and A.P. Knight. 1999. Analysis of toxic norditerpenoid alkaloids by electrospray, atmospheric pressure chemical ionization, and sequential tandem mass spectrometry. J. Agr. Food Chem. 47:5049-5058.

Hart, R.H. and M.J. Samuel. 1985. Precipitation, soils and herbage production on southeastern Wyoming range sites. J. Range Manage. 38:522-525.
Hughes, H.R. 1941. Larkspur poisoning preventative. San Juan District, Rocky Mountain Regional Bull., USDA Forest Service.

Knowles, K. 1974. An evaluation of larkspur poisoning in cattle and the trampling damage that occurs during grazing on a summer range in eastern Idaho. M.S. Thesis, Univ. of Idaho, Moscow, Ida.

Logan, J.R. 1973. Evaluation of a specificallyformulated supplement for the prevention of larkspur poisoning in cattle. M.S. thesis. Utah State Univ., Logan, Ut.

Manners, G.D., K.E. Panter, and S.W. Pelletier. 1995. Structure-activity relationships of norditerpenoid alkaloids occurring in toxic larkspur (Delphinium) species. J. Nat. Prod. 58:863-869.

NRC. 1996. National Research Council. Nutrient requirements of beef cattle. 7 th revised ed. National Academy Press, Washington, D.C.

Perez Corona, M.E., B.R.V. de Aldana, B.G. Criado, and A.G. Ciudad. 1998. Variations in nutritional quality and biomass production of semiarid grasslands. J. Range Manage. 51:570-576.

Pfister, J.A. and G.D. Manners. 1991. Mineral supplementation of cattle grazing larkspur-infested rangeland during drought. J. Range Manage. 44:105-111.

Pfister, J.A. and G.D. Manners. 1995. Effects of carbachol administration in cattle grazing tall larkspur-infested range. J. Range Manage. 48:343-349.

Pfister, J.A., K.E. Panter, and G.D. Manners. 1994. Effective dose in cattle of toxic alkaloids from tall larkspur (Delphinium barbeyi). Vet. Human Toxicol. 36:10-11.

Pfister, J.A., G.D. Manners, D.R. Gardner, K.W. Price, and M.H. Ralphs. 1996. Influence of alkaloid concentration on acceptability of tall larkspur (Delphinium spp.) to cattle and sheep. J. Chem. Ecol. 22:1147-1168.
Pfister, J.A., G.D. Manners, M.H. Ralphs, Z.X. Hong, and M.A. Lane. 1988. Effects of phenology, site and rumen fill on tall larkspur consumption by cattle. J. Range Manage. 41:509-514.

Pfister, J.A., F.D. Provenza, G.D. Manners, D.R. Gardner, and M.H. Ralphs. 1997a. Tall larkspur ingestion: can cattle regulate intake below toxic levels? J. Chem. Ecol. 23:759-777.

Pfister, J.A., M.H. Ralphs, G.D. Manners, D.R. Gardner, K.W. Price, and L.F. James. 1997b. Early season grazing of tall larkspur- (Delphinium spp.) infested rangeland. J. Range Manage. 50:391-398.

Pfister, J.A., D.R. Gardner, K.E. Panter, G.D. Manners, M.H. Ralphs, B.L. Stegelmeier, and T.K. Schoch. 1999. Larkspur (Delphinium spp.) poisoning in livestock. J. Nat. Toxins 8:81-94

Ralphs, M.H., D.T. Jensen, J.A. Pfister, D.B. Nielsen, and L.F. James. 1994. Storms influence cattle to graze larkspur: an observation. J. Range Manage. 47:275-278.

Rauzi, F. 1964. Late-spring herbage production on shortgrass rangeland. J. Range Manage. 17:210-212.

SAS. 1998. SAS/STAT guide for personal computers, Ver. 7. SAS Institute, Cary, N.C.

Smith, R. 1994. Handbook of Environmental Analysis, $2^{\text {nd }}$ Ed. Genium Publishing Co., Schenectady, N.Y.

Van Soest, P.J., J.B. Robertson, and B.A. Lewis. 1991. Methods for dietary fiber, neutral detergent fiber, and non-starch polysaccharides in relation to animal nutrition. J. Dairy Sci. 74: 3583-3597.

Whitson, T.D., W.R. Tatman, and R.J. Swearingen. 1992. Control of geyer larkspur (Delphinium geyeri Greene) at two growth stages with various herbicides. West. Sec. Weed Sci. Soc. Res. Prog. Rep. I 64-65. 


\title{
Elk and cattle forage use under a specialized grazing system
}

\author{
LACEY E. HALSTEAD ${ }^{1}$, LARRY D. HOWERY, GEORGE B. RUYLE, PAUL R. KRAUSMAN, AND \\ ROBERT J. STEIDL
}

Authors are former Graduate Research Assistant, Associate Professor and Range Management Specialist, Professor and Range Management Specialist, Professor, and Assistant Professor, School of Renewable Natural Resources, The University of Arizona, Tucson, Ariz. 85721. 'Current address: The Nature Conservancy of Texas, P.O. Box 1440, San Antonio, Tex. 78295-1440.

\begin{abstract}
The Walker Basin Allotment grazing system in central Arizona is designed to allocate resource use under elk (Cervus elaphus $\mathbf{L}$.) and cattle (Bos taurus L.) grazing. The grazing system was designed to promote biologically acceptable levels of forage use on the half of the allotment scheduled for cattle grazing and to rest the other half by attracting elk to pastures recently grazed by cattle. The objectives of our 2-year study were to determine whether the grazing system facilitated proper forage use as defined by recent forage use and residual stubble height guidelines (i.e., 30 to $40 \%$ use and an 8- to $10-\mathrm{cm}$ stubble height) and whether the system rested one half of the allotment from elk and cattle grazing. Mean ( \pm SEM) total elk and cattle forage use for western wheatgrass (Pascopyrum smithii Rydb.), the key forage species, was 32 and $61 \% \pm 7$ in 1997 and 1998, respectively; corresponding mean $( \pm S E M)$ stubble heights were 11 and $10 \mathrm{~cm} \pm$ 0.6. Mean total cattle and elk forage use in $1998(61 \%)$ exceeded the 30 to $40 \%$ use guidelines. However, mean end-of-year stubble height was never below $10 \mathrm{~cm}$. The grazing system did not provide half the allotment with complete rest; elk used all study pastures. Elk use was higher in pastures with heavier tree cover and steeper terrain in both years, regardless of where cattle grazing occurred. Elk grazing patterns were apparently more dependent on tree cover and topography than any changes in forage caused by the grazing system.
\end{abstract}

Key Words: Arizona, deferred grazing, paired-plot, rest-rotation, stubble height, western wheatgrass

Specialized grazing systems have been developed that use cattle grazing as a tool to alter forage characteristics and, thereby, modify elk (Cervus elaphus L.) distribution. Such grazing systems often include elements of rest-rotation, deferment, or both (Vavra and Sheehy 1996). Improvements in forage availability, palatability, production, and/or animal performance have been suggested as advantages to using specialized grazing systems

Research was funded by a grant from The University of Arizona Agriculture Experiment Station. We acknowledge the Coconino National Forest and the Arizona Game and Fish Department for their support of this project. We would like to thank Dr. Lamar Smith and 3 anonymous reviewers for reviewing earlier drafts of this paper. We thank Matt Barnes, Alex Connley, Tom DeLiberto, Vicki Gempko, Arlo Halstead, Elizabeth Howery, Dan Koepke, and Dave Womack for assistance in the field and laboratory.

Manuscript accepted 19 Sept. 01

\section{Resumen}

El sistema de asignación del apacentamiento de la cuenca Walker, en la parte central de Arizona, esta diseñado para asignar el uso de los recursos bajo el apacentamiento de alces (Cervus elaphus L.) y ganado bovino (Bos taurus L.). El sistema de apacentamiento se diseño para promover niveles biologicamente aceptables de utilización de forraje en la mitad del terreno programado para el ganado bovino y descansar la otra mitad mediante la atracción de los alces a potreros recién apacentados por bovinos. Los objetivos de nuestro estudio, de 2 años de duración, fueron determinar si el sistema de apacentamiento facilitó el uso adecuado del forraje tal como lo definen los lineamientos recientes de uso de forraje y altura del rastrojo (esto es, 30 a $40 \%$ de uso y 8 a $10 \mathrm{~cm}$ de altura del restrojo) y si el sistema descanso del alce y bovinos una de las mitades de la asignación. La media ( \pm EEM) de uso total de forraje por alces y bovinos para el "Western wheatgrass" (Pascopyrum smithii Rydb.), la especie clave, fue 32 y $61 \% \pm 7 \%$ en 1997 y 1998 respectivamente, $y$ la medias correspondientes $( \pm$ EEM) para la atura del rastrojo fueron 11 y $10 \mathrm{~cm} \pm 0.6$. En 1998, la media total de uso de forraje por alces y bovinos $(61 \%)$ excedió el 30 a $40 \%$ de uso establecido en los lineamientos. Sin embargo, la media de altura del rastrojo al final del año nunca fue menor a $10 \mathrm{~cm}$. El sistema de apacentamiento no proveyó un descanso completo para la mitad del terreno, el alce usó todos los potreros bajo estudio. El uso por el alce fue mayor en potreros con una densa cobertura de árboles y de terreno con pendiente, sin importar donde ocurrió el apacentamiento de los bovinos. Los patrones de apacentamiento del alce aparentemente fueron más dependientes de la cobertura de árboles y la topografía del terreno que cualquier cambio en el forraje causado por el sistema de apacentamiento.

(Anderson and Scherzinger 1975, Alt et al. 1992, Wisdom and Thomas 1996). These systems may attract elk to areas recently grazed by cattle (Gordon 1988, Alt et al. 1992, Frisina 1992), or they may produce little or no change in forage production, nutritional content, or herbivore distribution (Lacey and Van Poolen 1981, Yeo et al. 1993, Wambolt et al. 1997).

The Walker Basin Allotment grazing system in central Arizona combines elements of rest-rotation and deferment, employing seasonal cattle grazing on half the allotment each year (United States Forest Service [USFS], unpublished Walker Basin Allotment Management Plan 1990, Camp Verde, Ariz.). The 
objectives of our 2-year study were to determine whether the grazing system promoted target levels of forage use and residual stubble height (Holechek et al. 1998), and whether the system rested half the allotment from large ungulate herbivory each year.

\section{Materials And Methods}

\section{Study Area}

The Walker Basin Allotment (111 ${ }^{\circ} 40^{\prime}$ $40^{\prime} \mathrm{W}, 34^{\circ} 38^{\prime} 30^{\prime} \mathrm{N}$ ) is comprised of about 31,000 ha of USFS rangeland. The Walker Basin Allotment's 57 pastures are divided into 2 main sections that run west to east along an increasing elevational gradient. The Walker Basin Allotment has 3 seasonal ranges: winter $(1,220$ to $1,524 \mathrm{~m}$ elevation), transitional $(1,525$ to $1,982 \mathrm{~m}$ elevation), and summer (1,983 to $2,287 \mathrm{~m}$ elevation). Our study area (about 6,750 ha) consisted of 4 pastures ( 850 to 2,100 ha) on the transitional range (Fig. 1) because local resource managers identified this range as having high potential for elk and cattle competition (personal communication, USFS, Arizona Game and Fish Department, and ranch managers).

Western wheatgrass (Pascopyrum smithii Rydb.) has been identified by the USFS as the key herbaceous forage species in the study pastures (USFS, unpublished Walker Basin Allotment Management Plan 1990, Camp Verde, Arizona). Other plant species included blue grama (Bouteloua gracilis H.B.K.), sideoats grama (Bouteloua curtipendula Michx.), downy brome (Bromus tectorum L.), buckwheat (Eriogonum spp.), snakeweed (Gutierrezia sarothrae Pursh.), squawbush (Rhus trilobata Nutt.), emory oak (Quercus emoryi Torr.), pinyon pine (Pinus edulis Engelm.) and juniper (Juniperus osteosperma Torr.). Soils are predominantly classified as Vertic Haplustalfs (Terrestrial Ecosystems Survey of the Coconino National Forest 1992).

The growing season (frost-free days) on the transitional range extends from March to October. Average yearly precipitation is 33 $\mathrm{cm}$, occurring primarily from December to February and July to September (National Oceanic and Atmospheric Administration 1997). Winter precipitation occurs primarily as snow. The northern pastures (1 and 2) were near an ephemeral drainage and contained more pinyon pine and juniper cover than the southern pastures ( 3 and 4 ).

\section{Description of Grazing System and Herbivores}

The Walker Basin Allotment grazing system is designed to promote biologically acceptable levels of forage use by cattle, elk, and other wild herbivores and to rest half of the allotment by attracting elk and other wild ungulates to pastures recently grazed by cattle (USFS, unpublished Walker Basin Allotment Management Plan 1990, Camp Verde, Ariz.). Hereford and Hereford cross-bred (Saler, Braford, Brahman, Angus, Gelbvieh) cow-calf pairs were used in this experiment and handled following the University of Arizona's Animal Care Protocol \# 96-118. During 1997, 413 cow-calf pairs were used (mean body weight $=476 \mathrm{~kg} \pm 62$ $\mathrm{SD}$ ), while $450 \mathrm{cow}$-calf pairs were used in 1998 (mean body weight $=457 \mathrm{~kg} \pm 87$ SD). Each year, cattle were moved up the elevational gradient through pastures on one half of the allotment during the growing season (about 14 days/pasture) and moved down the elevational gradient on the same half during the dormant season (about 5 days/grazed pasture). The other half of the allotment was rested from cattle grazing the entire year (i.e., rested pastures). Seasonal cattle grazing is used to increase palatable regrowth, which is hypothesized to attract elk to pastures recently grazed by cattle, thereby resting the other half of the allotment from cattle and elk herbivory.

According to the Arizona Game and Fish Department, elk is the main wild herbivore species that significantly impacts western wheatgrass, the key forage species used in this study. Jack rabbits (Lepus californicus Gray), pronghorn (Antilocapra americana Ord), mule deer (Odocoileus hemionus Rafinesque), and white-tailed deer (Odocoileus virginianus Rafinesque) are thought to use insignificant amounts of western wheatgrass compared with elk and cattle due to lower animal numbers or dietary differences (Thomas Britt, Regional Supervisor, Arizona Game and Fish Department, personal communication, Vavra et al. 1989). Thus, our research focused on elk and cattle impacts on western wheatgrass.

\section{General Sampling Procedures}

The study was conducted from March 1997 to October 1998. We estimated forage use by elk and cattle and residual stubble height during 2 growing seasons. The southern pastures ( 3 and 4) were grazed by cattle in 1997 and the northern pastures (1 and 2) were grazed by cattle in 1998 as required by the USFS grazing management plan (Fig. 1). Average stocking rates for cattle, calculated using definition ' $a$ ' of the Glossary Revision Special Committee report (1989), were 5.1 and 6.9 ha/AUM during 1997 and 1998, respectively (Fig. 1). All pastures were accessible to elk during the entire study.

Paired-plot and stubble height techniques (Interagency Technical Reference 1996) were used to evaluate grazing of western wheatgrass in 12 randomly selected 3-ha sampling areas (3/pasture). Each sampling area was located $\geq 0.4 \mathrm{~km}$ from well-traveled roads, fences, and water and $\geq 0.3 \mathrm{~km}$ from adjacent sampling areas. Sampling areas contained 6 paired-plot units. Each paired-plot unit consisted of 1 protected macroplot $\left(1.7-\mathrm{m}^{2}\right.$ grazing exclosure), and two, $1.7-\mathrm{m}^{2}$ unprotected macroplots, for a total of 72 protected and

\section{$\mathbf{N} \uparrow$}

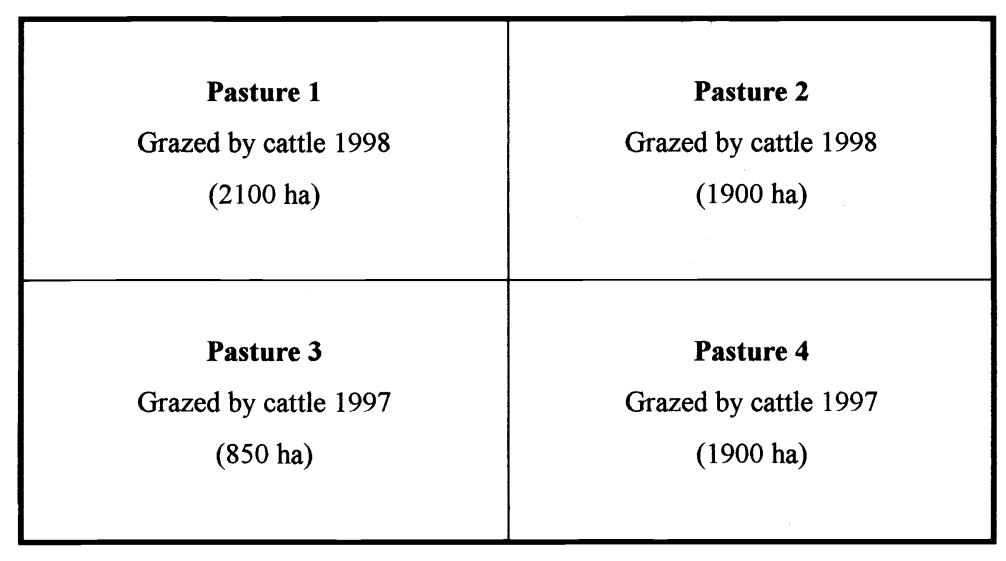

Fig. 1. Study pasture layout on the Walker Basin Allotment, central Arizona. Cattle grazed southern pastures ( 3 and 4) Jun./Jul. and Nov. of 1997, and northern pastures (1 and 2) Jun./Jul. and Nov. of 1998. Elk had access to study pastures year-round. 
144 unprotected plots in the study area (i.e., 72 paired-plot units). Two unprotected macroplots, rather than the traditional 1 , were matched with each protected macroplot to account for possible patch grazing by cattle and elk (Klingman et al. 1943, Grelen 1967). Unprotected and protected macroplots were matched based on similar ocular estimates of western wheatgrass phytomass. Each sampling area also contained a 400-m stubble height transect located between protected and unprotected macroplots and $\geq 10 \mathrm{~m}$ from protected macroplots.

To avoid attracting animals to protected plots within sampling areas, each protected plot was $\geq 100 \mathrm{~m}$ from the others. Protected and unprotected plots were $\geq 50$ $\mathrm{m}$ apart, and unprotected plots within a paired-plot unit were $\geq 10 \mathrm{~m}$ apart. To minimize bias due to enhanced growth within protected plots, new paired-plot units were established in March each year (Owensby 1969). Before initially establishing paired-plot units, we tested the precision of ocular matching by clipping, drying, and weighing western wheatgrass from 29 pairs of $0.25-\mathrm{m}^{2}$ circular plots that were later used to clip subsamples within paired-plot units. A paired t-test revealed no difference between paired test plots $(\mathrm{P}$ $>0.2, \alpha=0.05)$. The same observer always established paired-plot units.

We estimated forage use and stubble height in each pasture in 3 sampling periods: 1) immediately before cattle entered grazed pastures, 2) immediately after cattle exited grazed pastures, and 3) at the end of the growing season, about 3-4 months after cattle exited grazed pastures (Fig. 2 and Fig. 3; Tables 1 and 2). Measurements made before cattle grazed (early/mid-June) estimated relative elk use in all pastures. Measurements made after cattle grazed (mid-June/early July) estimated relative cattle and/or elk use, while measurements made at the end of the growing season (mid-October) estimated total forage use for the entire growing season (cattle and/or elk). Relative use describes the amount of forage consumed or destroyed up to a certain time during the growing season but prior to peak standing crop (e.g., June or July; Frost et al. 1994). Total forage use is "the proportion of current year's forage consumed or destroyed by grazing animals," measured at the end of the growing season (Glossary Revision Special Committee 1989). Cattle grazed study pastures about 5 days in midNovember (dormant season), and elk migrating to winter ranges likely used study pastures at this time. However, we

Table 1. Mean relative and total western wheatgrass forage use (\%) under 2 treatments (elk grazing and elk/cattle grazing) across 3 sampling periods on the Walker Basin Allotment, central Arizona, 1997/1998 (SEM = 7).

\begin{tabular}{|c|c|c|c|c|}
\hline \multirow[b]{2}{*}{ Year/Grazing animal $^{2}$} & \multirow[b]{2}{*}{ Pasture } & \multicolumn{3}{|c|}{ Sampling period $^{1}$} \\
\hline & & $\begin{array}{l}\text { Before cattle } \\
\text { grazing }\end{array}$ & $\begin{array}{c}\text { After cattle } \\
\text { grazing }\end{array}$ & $\begin{array}{c}\text { End of } \\
\text { growing season }\end{array}$ \\
\hline & & \multicolumn{3}{|c|}{ 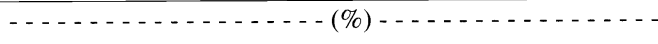 } \\
\hline \multicolumn{5}{|l|}{1997} \\
\hline Elk & 1 and 2 & 28 & 26 & 22 \\
\hline Elk and cattle & 3 and 4 & 14 & 37 & 32 \\
\hline \multicolumn{5}{|l|}{1998} \\
\hline Elk and cattle & 1 and 2 & 28 & 58 & 61 \\
\hline Elk & 3 and 4 & 13 & 23 & 26 \\
\hline
\end{tabular}

${ }^{\mathrm{I}}$ Before cattle grazing = relative forage use, early/mid-Jun.; After cattle grazing = relative forage use, mid-Jun./early Jul.; End of growing season, or 3 to 4 months after cattle exited grazed pastures = total forage use, mid-Oct.

${ }^{2}$ Year and grazing animal main effects were significant and are reported in the Results section and Figs. 2a,2b.

did not measure dormant season grazing because of snow depth.

\section{Paired-plot Sampling}

For each sampling period, we clipped western wheatgrass from 2 randomly selected paired-plot units in each sampling area within each pasture for a total of 24 paired-plot samples. All plots were clipped to ground level. During 1997, we used a $0.25-\mathrm{m}^{2}$ circular frame to clip 4 subplots within each $1.7-\mathrm{m}^{2}$ macroplot. We averaged the 4 subplot dry weights to obtain 1 mean protected weight for each protected macroplot. For the 2 corresponding unprotected macroplots, we averaged the 8 subplot dry weights (4 subplots $\mathrm{x} 2$ macroplots) to obtain 1 mean unprotected weight. Percentage use for a paired-plot unit was the ratio of the mean unprotected and protected weights. Negative utilization values from paired-plot units were zeroed (Werner and Urness 1998). Mean use for a sampling area was calculated from the 2 randomly selected paired-plot units. Mean use for each pasture treatment (grazed or rested) was calculated across the appropri-

Table 2. Mean western wheatgrass residual stubble height $(\mathrm{cm})$ under 2 treatments (elk grazing and elk/cattle grazing) across 3 sampling periods on the Walker Basin Allotment, central Arizona, 1997/1998 $(\mathrm{SEM}=\mathbf{0 . 6})$.

\begin{tabular}{|c|c|c|c|c|}
\hline \multirow[b]{2}{*}{ Year/Grazing animal $^{2}$} & \multirow[b]{2}{*}{ Pasture } & \multicolumn{3}{|c|}{ Sampling period ${ }^{1}$} \\
\hline & & $\begin{array}{l}\text { Before cattle } \\
\text { grazing }\end{array}$ & $\begin{array}{l}\text { After cattle } \\
\text { grazing }\end{array}$ & $\begin{array}{c}\text { End of } \\
\text { growing season }\end{array}$ \\
\hline & & \multicolumn{3}{|c|}{$\ldots \ldots \ldots-\ldots-\ldots-\ldots(\mathrm{cm})-\ldots \ldots \ldots$} \\
\hline \multicolumn{5}{|l|}{1997} \\
\hline Elk & 1 and 2 & 12 & 10 & 12 \\
\hline Elk and cattle & 3 and 4 & 13 & 10 & 11 \\
\hline \multicolumn{5}{|l|}{1998} \\
\hline Elk and cattle & 1 and 2 & 16 & 14 & 10 \\
\hline Elk & 3 and 4 & 17 & 16 & 12 \\
\hline
\end{tabular}

${ }^{1}$ Before cattle grazing $=$ relative forage use, early/mid-Jun.; After cattle grazing = relative forage use, mid-Jun./early Jul.; End of growing season, or 3 to 4 months after cattle exited grazed pastures = total forage use, mid-Oct.

${ }^{2}$ Year and grazing animal main effects were significant and are reported in the Results section and Figs. 3a,3b. 


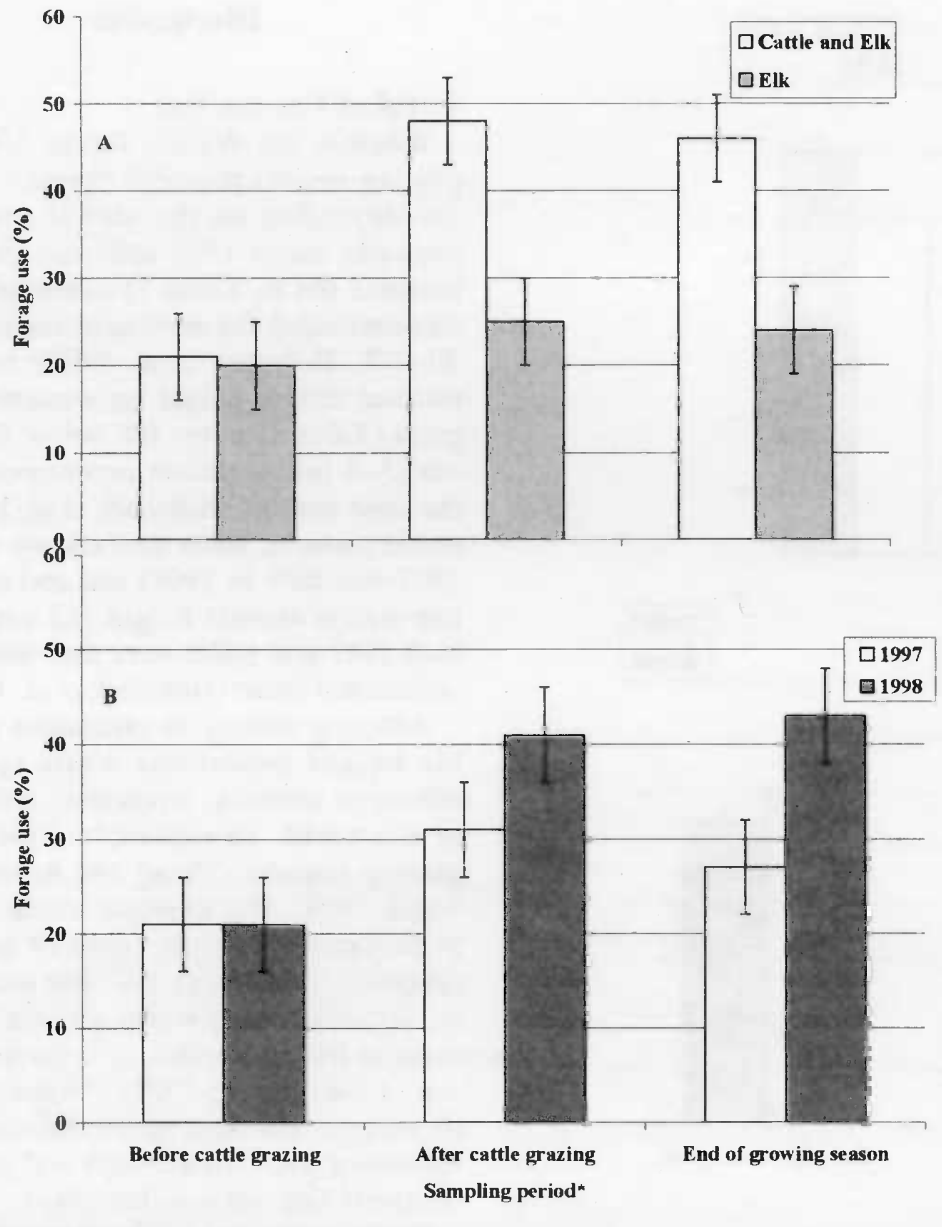

Fig. 2. Grazing animal (A) and year (B) effects on relative and total western wheatgrass forage use (\%) across 3 sampling periods on the Walker Basin Allotment, central Arizona (SEM = 5). " Sampling periods were: Before cattle grazing = relative forage use, early/midJun.; After cattle grazing = relative forage use, mid-Jun./early Jul.; End of growing season, or 3 to 4 months after cattle exited grazed pastures = total forage use, mid-Oct.

\section{Stubble Height Sampling}

Stubble height sampling methodology was the same in both years. For each sampling period, the average height of 60 individual western wheatgrass plants was measured (Interagency Technical Reference 1996). Individual plants (grazed and ungrazed) were measured as encountered at approximate $3-\mathrm{m}$ intervals along a transect. An individual western wheatgrass plant was defined as a turf of vegetation occupying a circle at least $5 \mathrm{~cm}$ in diameter. Height of the extended green leaf area of each plant was measured to the nearest 0.5 $\mathrm{cm}$ after gently placing a ruler in the middle of the turf circle. When a plant was grazed unevenly, we ocularly estimated the average height of the $5-\mathrm{cm}$ turf area. Mean residual stubble height for each sampling area was calculated from the 60 plants, and mean residual stubble height for pastures was calculated as described for paired-plot estimates.

\section{Statistical Analyses}

We employed a completely randomized design experiment with $2 \times 2$ factorial arrangement of treatments. Because we measured forage use of western wheatgrass and residual stubble height repeatedly in sampling areas, we used a multivariate repeated measures analysis of variance to test the effects of grazing animal (elk vs elk and cattle), year (1997 vs 1998), and grazing animal $x$ year interaction. We applied an arc-sine transformation to forage-use data prior to analysis (Steel and Torrie 1980)

\section{Results}

Forage use was influenced by type of grazing animal (Fig. 2A; $\mathrm{F}_{2,19}=6.1 ; \mathrm{P}=$ 0.009) and year (Fig. 2B; $\mathrm{F}_{2,19}=2.9 ; \mathrm{P}=$ 0.08 ) and there was no type of animal $x$

\section{Forage Use}

year interaction $(P>0.9)$. On average, elk had used about $20 \%$ (relative use) of western wheatgrass in pastures scheduled for grazing and rest before cattle were released into the study area (Fig. 2A). In rested pastures (elk use), forage use measured after cattle grazing, and at the end of the growing season, averaged $25 \%$ (relative use) and $24 \%$ (total use), respectively, while corresponding use in grazed pastures (cattle and elk use) averaged $48 \%$ (relative use) and $46 \%$ (total use). Total forage use averaged 22 percentage points higher in grazed pastures $(46 \%)$ than in rested pastures $(24 \%)$ at the end of the growing season.

Relative forage use attributable to elk averaged about $20 \%$ before cattle arrived in the study area both years of the study (Fig. 2B). However, forage use measured after cattle grazing and at the end of the growing season averaged 10 and 16 percentage points higher in 1998 than in 1997, respectively.

\section{Residual Stubble Height}

Residual stubble height also was influenced by type of grazing animal (Fig. 3A; $\mathrm{F}_{2,19}=3.6 ; \mathrm{P}=0.06$ ) and year (Fig. 3B; $\left.\mathrm{F}_{2,19}=32.2 ; \mathrm{P}<0.0001\right)$, and there was no type of animal $\mathrm{x}$ year interaction $(\mathrm{P}>$ $0.8)$. Stubble height averaged $14 \mathrm{~cm}$ in pastures scheduled for grazing and rest before cattle arrived at the study area (Fig. $3 \mathrm{~A}$ ). In grazed pastures (cattle and elk use), mean stubble height decreased to 12 $\mathrm{cm}$ after cattle grazing and to $10 \mathrm{~cm}$ at the end of the growing season, compared with 13 and $12 \mathrm{~cm}$ in rested pastures (elk use), respectively, during those same sampling periods. Stubble heights averaged $2 \mathrm{~cm}$ lower in grazed pastures $(10 \mathrm{~cm})$ than in rested pastures $(12 \mathrm{~cm})$ by the end of the growing season.

In 1997, stubble heights, measured before cattle grazing $(12 \mathrm{~cm})$ and after cattle grazing $(10 \mathrm{~cm})$, averaged 4 and $5 \mathrm{~cm}$ lower than respective 1998 stubble heights (i.e., 16 and $15 \mathrm{~cm}$; Fig. 3B). However, stubble height averaged about the same by the end of the growing season for both years of the study (i.e., 12 and $11 \mathrm{~cm}$ in 1997 and 1998, respectively).

\section{Elk and Cattle Grazing Patterns}

Because it is important to discuss both relative and total forage use in relation to corresponding stubble heights across sampling periods, we tabulated results by year and grazing treatment (Tables 1 and 2). Higher use levels occurred after cattle had occupied grazed pastures (cattle and elk use), which typically yielded lower stub- 

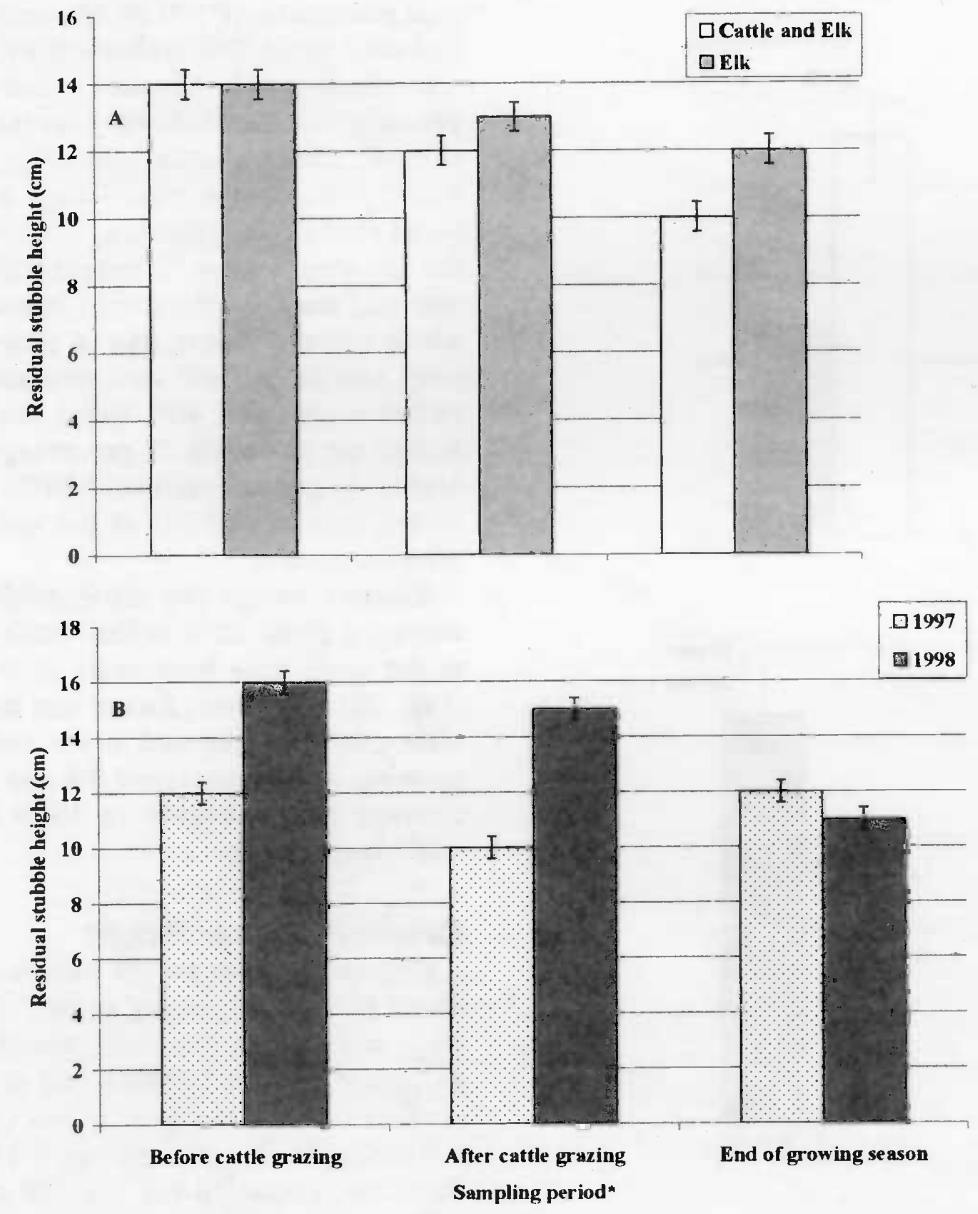

Fig. 3. Grazing animal (A) and year (B) effects on western wheatgrass stubble height $(\mathrm{cm})$ across 3 sampling periods on the Walker Basin Allotment, central Arizona $(\mathrm{SEM}=\mathbf{0 . 4}){ }^{*}$ Sampling periods were: Before cattle grazing = relative forage use, early/mid-Jun.; After cattle grazing = relative forage use, mid-Jun./early Jul.; End of growing season, or 3 to 4 months after cattle exited grazed pastures $=$ total forage use, mid-Oct.

ble heights compared with rested pastures (elk use) during both years of the study (Tables 1 and 2). As expected, mean forage use in grazed pastures was higher after cattle grazing ( 37 and $58 \%$ relative forage use during 1997 and 1998, respectively), and at the end of the growing season (32 and $61 \%$ total forage use during 1997 and 1998 , respectively), than before cattle grazing (14 and $28 \%$ relative forage use during 1997 and 1998, respectively; Table 1).

Corresponding mean stubble heights in grazed pastures were lower after cattle grazing (10 and $14 \mathrm{~cm}$ during 1997 and 1998 , respectively), and at the end of the growing season (11 and $10 \mathrm{~cm}$ during 1997 and 1998, respectively), than before cattle grazing (13 and $16 \mathrm{~cm}$ during 1997 and 1998, respectively; Table 2). Interestingly, stubble height at the end of the growing season was about the same both years of the study regardless of grazing treatment (i.e., range $=10-12 \mathrm{~cm}$;
Table 2), whereas estimates of total forage use (Table 1) were much higher in grazed pastures during $1998(61 \% \pm 7)$ than in $1997(32 \% \pm 7)$. Higher overall stubble height in 1998 was correlated with higher mean western wheatgrass standing crop (i.e., 277 vs. $471 \mathrm{~kg} \mathrm{ha}^{-1}$ in 1997 and 1998, respectively, SEM = 32). Higher production levels in 1998 apparently allowed higher total forage use levels than in 1997, and contributed to similar end-of-growingseason stubble heights both years.

In rested pastures, mean relative and total elk use remained relatively light and similar across the 3 sampling periods both years (i.e., range $=22-26 \%$ during 1997 ; range $=13-26 \%$ during 1998; Table 1). Corresponding mean stubble heights in rested pastures were also fairly constant across sampling periods during 1997 (i.e., 12,10 , and $12 \mathrm{~cm}$, respectively), but showed a declining trend during 1998 (i.e., 17,16 , and $12 \mathrm{~cm}$, respectively; Table 2 ).

\section{Discussion}

\section{Level of Forage Use}

Whether the Walker Basin Allotment grazing system provided "proper" forage use depended on the metric used. For example, mean 1998 total use in grazed pastures $(61 \%$, Table 1$)$ exceeded levels recommended for semi-arid ranges (e.g., 30-40\%, Holechek et al. 1998); however, residual stubble height for western wheatgrass (Table 2) never fell below the 8-10 cm (3-4 in) minimum recommended by the same authors (Holechek et al. 1998). In rested pastures, mean total elk use $(22 \%$ in 1997 and 26\% in 1998) and end-of-growing-season stubble height $(12 \mathrm{~cm}$ during both 1997 and 1998) were also within recommended limits (Holechek et al. 1998).

Adhering strictly to utilization or stubble height guidelines while ignoring effects of intensity, frequency, and season of use yields an incomplete picture of grazing impacts (Zhang and Romo 1995, Smith 1998). For example, cattle grazing in each pasture occurred only 19 days/year (intensity, frequency) and after seed set or during dormancy, when western wheatgrass is less vulnerable to herbivory (season of use) (Smith 1998). Pastures grazed by cattle 1 year were rested from cattle the following year (frequency) and receiyed relatively light elk use (intensity).

Because total use in rested pastures was nearly the same in June as in October (Table 1), we concluded that most elk use occurred early in the growing season when western wheatgrass was in the vegetative stage (season of use). Perennial grasses tend to be more tolerant of grazing during the vegetative stage compared to the reproductive "boot" stage because meristematic tissue is relatively closer to ground (Frost et al. 1994, Smith 1998).

The sampling technique used may also influence the results obtained. One disadvantage of the paired-plot technique is that use estimates are imprecise unless sample size is very large (Klingman et al. 1943). An attempt in 1998 to decrease paired-plot unit variability within sampling areas by individually matching subsamples was ineffective (Bork and Werner 1999). Additionally, Bork and Werner (1999) suggested that the standard practice of zeroing negative utilization values when using the paired-plot technique could contribute 10 overestimation of forage use on spatially heterogeneous ranges. Negative use values from paired-plot units were zeroed following Werner and Urness (1998). Zeroed paired-plot data in our study were 9 percentage points higher than 
non-zeroed paired-plot data (Halstead 1998); thus, overall results and interpretation would not have changed appreciably had non-zeroed use data been used as suggested by Bork and Werner (1999).

The paired-plot technique has also been shown to overestimate forage production and use due to enhanced moisture conditions within protected plots (i.e., the "microclimate effect"; Grelen 1967, Owensby 1969, Halstead 1998). The microclimate effect may be magnified when birds and small mammals "fertilize" protected plots or when precipitation and the resulting production are above average (Owensby 1969). Stubble height and forage production were higher in 1998; however, 1998 total use in grazed pastures exceeded 1997 use levels despite slightly lower stocking rates in 1998 (i.e., 5.1 vs $6.9 \mathrm{ha} / \mathrm{AUM}$ in 1997 and 1998, respectively). Finally, rougher topography in the northern pastures ( 1 and 2) compared to the southern pastures ( 3 and 4) may have limited cattle distribution in 1998, contributing to the higher use levels and the seasonal decline in stubble heights measured that year.

\section{Elk and Cattle Grazing Patterns}

The grazing system did not provide half of the study pastures with complete rest because elk used all pastures both years of the study. In 1997, relative and total elk use in rested pastures remained slightly below the recommended 30 to $40 \%$ range during all 3 sampling periods (Table 1). In 1998, the same trend in rested pastures held except there was relatively less elk use before cattle grazing (13\%). A decline in 1998 stubble height for both grazed (10 $\pm 0.6)$ and rested $(12 \pm 0.6)$ pastures at the end of the growing season suggested that some elk use occurred in the study area after cattle grazing (Table 2). However, similar forage use estimates made after cattle grazing, and at the end of the growing season during both 1997 and 1998, suggested that elk did not return to the study area in high enough numbers to significantly increase total forage use in either grazed or rested pastures from June to October (Table 1). We therefore conclude that forage manipulation by cattle did not attract elk to cattle-grazed pastures within the same year. We also conclude that elk use was not influenced by previous year's cattle grazing, because elk use prior to the arrival of cattle was about twice as high in pastures 1 and 2 as in pastures 3 and 4 both years, regardless of grazing treatment (Table 1). Corresponding residual stubble heights were slightly lower in pas- tures 1 and 2 compared to pastures 3 and 4 both years (Table 2). Pastures 1 and 2 were near a drainage thought to be used by migrating elk and had more pinyon and juniper cover than pastures 3 and 4 . Thus, elk use patterns were apparently more related to preferences for protective cover, topography, and traditional migration patterns than the grazing system's hypothesized effect on forage regrowth and palatability (Skovlin 1982, Wallace and Krausman 1987, Vavra 1992, Dyke et al. 1998).

\section{Conclusions and Management Implications}

Our study provided local knowledge of cattle-elk forage use and stubble height patterns in central Arizona, which is an essential first step for managers to evaluate whether management practices are achieving resource objectives (McIntosh and Krausman 1982, O'Neil 1985, Cook et al. 1998). Forage use data provides a general idea of the level and patterns of large ungulate herbivory (Miller et al. 1994, Smith 1998). Stubble height data complements forage use and other monitoring data because it is correlated with erosion protection, soil moisture retention, forage regrowth potential, and small animal and insect habitat (Hall and Lindenmuth 1998). Although it appears that the Walker Basin Allotment grazing system promotes proper levels of residual vegetation, a more comprehensive rangeland monitoring program is needed to confirm or refute this assertion (Laycock 1998, Smith 1998). Rangeland trend data (e.g., plant species composition, herbaceous and shrub cover, vegetation structure) would help determine long-term sustainability of forage use or residual stubble height levels.

Because elk foraging on the Walker Basin Allotment was evidently affected more by elk habitat preferences than the grazing system, further field investigations are needed. For example, the relationship between elk and cattle forage use and temporal and spatial distribution on the Walker Basin Allotment may differ at higher or lower elevations and result in different elk use patterns. Manipulative experiments at different elevations are needed to determine whether habitat changes induced by the grazing system (i.e., forage quality and quantity) exert more influence on elk at these elevations than other habitat elements like cover and topography (Vavra and Sheehy 1996, Cook et al. 1998).
Elk and other wild ungulates have the freedom to choose foraging sites that best meet their physiological and behavioral needs. Managers designing dual or multispecies grazing systems should consider how intensity and season of livestock grazing, in combination with local level habitat characteristics and animals' behavioral habits, might influence spatial and temporal movements of wild ungulates (Cook et al. 1998, Unsworth et al. 1998).

\section{Literature Cited}

Alt, K. L., M. R. Frisina, and F. J. King. 1992. Coordinated management of elk and cattle, a perspective-Wall Creek Wildlife Management Area. Rangelands 14:12-15.

Anderson, E. W. and R. J. Scherzinger. 1975. Improving quality of winter forage for elk by cattle grazing. J. Range Manage. 28:120-125.

Bork, E. W. and S. J. Werner. 1999. Viewpoint: Implications of spatial variability for estimating forage use. J. Range Manage. 52:151-156.

Cook, J. G., L. L. Irwin, L. D. Bryant, R. A. Riggs, and J. W. Thomas. 1998. Relations of forest cover and condition of elk: a test of the thermal cover hypothesis in summer and winter. Wildl. Monogr. 62:1-61.

Dyke, F. G., W. C. Klein, and S. T. Stewart. 1998. Long-term range fidelity in Rocky Mountain elk. J. Wildl. Manage. 62:1020-1035.

Frisina, M. R. 1992. Elk habitat use within a rest-rotation grazing system. Rangelands 14:93-96.

Frost, W. E., E. L. Smith, and P. R. Ogden. 1994. Utilization guidelines. Rangelands 16 : 256-259.

Glossary Revision Special Committee. 1989. A glossary of terms used in range management. 3rd ed. Soc. Range Manage., Denver, Colo.

Gordon, I. J. 1988. Facilitation of red deer grazing by cattle and its impact on red deer performance. J. Appl. Ecol. 25:1-9.

Grelen, H. E. 1967. Comparison of cage methods for determining utilization on pinebluestem range. J. Range Manage. 20:94-96.

Hall, F. C. and R. Lindenmuth. 1998. Developing and achieving management objectives on National Forest System lands, p. 47-49. In: Stubble height and utilization measurements: uses and misuses. Agr. Exp. Sta. Oregon State Univ., Corvallis, Ore.

Halstead, L. E. 1998. Monitoring elk and cattle forage utilization under a specialized grazing system in Arizona. M.S. Thesis, The Univ. of Arizona, Tucson, Ariz.

Holechek, J., R. D. Pieper, and C. H. Herbel. 1998. Range management, principles and practices. 3rd ed. Prentice Hall, Upper Saddle River, N.J. 
Interagency Technical Reference. 1996. Utilization studies and residual measurements. BLM National Appl. Resource Sci. Center. Cooperative Exten. Serv., USFS, NRCS, BLM.

Klingman, D. L., S. R. Miles, and G. O. Mott. 1943. The cage method for determining consumption and yield of pasture herbage. J. Amer. Soc. Agron. 35:739-746.

Lacey, J. R. and H. W. Van Poolen. 1981. Comparison of herbage production on moderately grazed and ungrazed western ranges. J. Range Manage. 34: 210-212.

Laycock, W. A. 1998. Variation in utilization estimates caused by differences among methods, years, and observers, p. 17-24. In: Stubble height and utilization measurements: uses and misuses. Agr. Exp. Sta. Oregon State Univ., Corvallis, Ore.

McIntosh, B. J. and P. R. Krausman. 1982. Elk and mule deer distributions after a cattle introduction in northern Arizona, p. 545-552. In: J. M. Peek and P. D. Dalke (eds.), Proc. 10 Wildlife-Livestock Relationships Symposium Univ. of Idaho Forestry, Wildl. and Range Exp. Sta., Moscow, Ida.

Miller, W. H., J. G. Brock, and J. Horsley. 1994. Elk-cattle interaction in central Arizona. Arizona Game and Fish Dep. Tech. Rep. Phoenix, Ariz.

National Oceanic and Atmospheric Administration. 1997. Climatological data annual summary Arizona. Vol. 101(13), ISSN 0145-0387. Natl. Environmental Satellite, Data and Info. Service, Natl. Climatic Data Ctr., Asheville, N.C.
O'Neil, J. 1985. Management strategies and future research on elk in Arizona, p. 35-38. In: G. W. Workman (ed.), Proc. of Symp. on Western Elk Management. Utah State Univ. Agr. Exp. Sta., Logan, Ut.

Owensby, C. E. 1969. Effect of cages on herbage yield in true prairie vegetation. $\mathrm{J}$. Range Manage. 22:131-132.

Skovlin, J. M. 1982. Habitat requirements and evaluations, p. 369-413. In: Thomas, J. W. and D. E. Toweill (eds.), Elk of North America, ecology and management. Stackpole Books, Harrisburg, Penn.

Smith, E. L. 1998. Seasonal effects on the measurement and interpretation of utilization, p. 9-16. In: Stubble height and utilization measurements: uses and misuses. Agr. Exp. Sta. Oregon State Univ., Corvallis, Ore.

Steel, R. G. D. and J. H. Torrie. 1980. Principles and procedures of statistics, a biometrical approach. 2nd ed. McGraw Hill Book Co., New York, N.Y.

Terrestrial Ecosystems Survey of the Coconino National Forest. 1992. USDA/USFS Southwestern Region.

Unsworth, J. W., L. Kuck, E. O. Garton, and B. R. Butterfield. 1998. Elk habitat selection on the Clearwater National Forest, Idaho. J. Wildl. Manage. 62:1255-1263.

Vavra, M. 1992. Livestock and big game relationships. Rangelands 14:57-59.

Vavra, M. and D. Sheehy. 1996. Improving elk habitat characteristics with livestock grazing. Rangelands 18:182-185.
Vavra, M., M. McInnis, and D. Sheehy. 1989. Implications of dietary overlap to management of free-ranging large herbivores. Proc. Western Sect.Amer. Soc. of Anim. Sci. 40:489-495.

Wallace, M. C. and P. R. Krausman. 1987. Elk, mule deer, and cattle habitats in central Arizona. J. Range Manage. 40:81-83.

Wambolt, C. L., M. R. Frisina, K. S. Douglass, and H. W. Sherwood. 1997. Grazing effects on nutritional quality of bluebunch wheatgrass for elk. J. Range Manage. 50:503-506.

Werner, S. J. and P. J. Urness. 1998. Elk forage utilization within rested units of restrotation grazing systems. J. Range Manage. 51:14-18.

Wisdom, M. J. and J. W. Thomas. 1996. Elk, p. 157-182. In: P. R. Krausman (ed.), Rangeland wildlife. Soc. Range Manage., Denver, Colo.

Yeo, J. J., J. M. Peek, W. T. Wittinger, and C. T. Kvale. 1993. Influence of rest-rotation cattle grazing on mule deer and elk habitat use in east-central Idaho. J. Range Manage. 46:245-250.

Zhang, J. and J. T. Romo. 1995. Impacts of defoliation on tiller production and survival in northern wheatgrass. J. Range Manage. $48: 115-120$. 


\title{
Sediment movement and filtration in a riparian meadow following cattle use
}

\author{
R.R. McELDOWNEY, M. FLENNIKEN, G.W. FRASIER, M.J. TRLICA, AND W.C. LEININGER
}

Authors are Riparian/Wetland Ecologist, SAIC, 8100 Shaffer Parkway, Suite 100, Littleton, Colo. 80127, Natural Resource Specialist, Larimer County Open Lands, Loveland, Colo. 80537, Research Hydraulic Engineer (Retired), USDA, Agriculture Research Service, Crops Research Lab, Fort Collins, Colo. 80523, and Professors, Rangeland Ecosystem Science Department, Colorado State University, Fort Collins, Colo. 80523.

\begin{abstract}
Improper livestock grazing practices in western U.S. riparian areas may reduce the nutrient and pollutant removal function of riparian communities, resulting in degradation of surface water quality. Short duration-high intensity cattle use in $3 \times 10 \mathrm{~m}$ plots was evaluated in a montane riparian meadow in northern Colorado to quantify livestock effects on sediment movement and filtration under simulated rainfall $\left(\approx 100 \mathrm{~mm}_{\text {hour }}{ }^{-1}\right)$ plus overland flow $\left(\approx 25 \mathrm{~mm}\right.$ hour $\left.^{-1}\right)$ conditions. Four treatments: 1) control, 2) mowed to $10 \mathrm{~cm}$ stubble height, 3) trampled by cattle, and 4) cattle grazed plus trampled (grazed) were evaluated. Sixty kg of sediment was introduced to overland flow in each plot. Sediment movement was evaluated using sediment traps positioned in microchannels and on vegetation islands at 5 distances downslope from the upper end of the plots and by sediment front advancement. Most sediment deposition occurred within the first meter downslope from application. About $90 \%$ of the applied sediment was filtered from runoff within $10 \mathrm{~m}$ in the control and mowed treatments, while approximately 84 and $77 \%$ of the applied sediment was trapped in the trampled and grazed treatment plots, respectively. The primary variables that influenced sediment filtration were stem density and surface random roughness. Stem density was the most influential variable that affected sediment filtration. Cattle grazing reduced the stem density by $40 \%$. Monitoring of stem density should aid land managers in regulating cattle use of riparian communities and facilitate the protection of surface water quality from sediment in overland flow.
\end{abstract}

Key Words: Vegetation filter strip, stem density, rainfall simulation, NPS pollution, grazing, trampling

Sediment movement from upland areas is typically associated with intense precipitation events (Edwards and Owens 1991, Larson et al. 1997). Excessive sediment loads in runoff water can cause radical changes in streambed morphology, loss of aquatic habitat, reduction in storage capacity of reservoirs, and loss of aesthetic value (Novotny and Olem 1994).

Vegetated filter strips (VFS) are used as a Best Management

Research was funded by the USDA-CSREES Rangeland Research Grants Program, USDA-Agricultural Research Service, and the Colorado State University Agricultural Experiment Station. Authors wish to thank Dennis Mueller, Maxine Cottrell, and Elizabeth Nibarger for their assistance with the data collection.

Manuscript accepted 20 Oct. 01.

\section{Resumen}

Las prácticas inadecuadas de apacentamiento de ganado en áreas ribereñas del oeste de E.U.A pueden reducir la función removedora de nutrientes y contaminantes de las comunidades ribereñas, resultando en la degradación de la calidad del agua superficial. En parcelas de $3 \times 10 \mathrm{~m}$ en una pradera ribereña montana del norte de Colorado se evaluó el sistema de apacentamiento de corta duración - alta intensidad para cuantificar los efectos del ganado en el movimiento de sedimento y filtración bajo lluvia simulada $\left(\approx 100 \mathrm{~mm}\right.$ hora $\left.{ }^{1}\right)$ más condiciones de flujo superficial $\left(\approx 25 \mathrm{~mm}\right.$ hora $\left.{ }^{1}\right)$. Se evaluaron cuatro tratamientos: 1$)$ control, 2) segado a $10 \mathrm{~cm}$ de altura del rastrojo, 3) pisoteado por ganado y 4) apacentado por ganado mas pisoteado (apacentado). En el flujo superficial de cada parcela se introdujeron $60 \mathrm{~kg}$ de sedimento. El movimiento de sedimento se evaluó usando trampas de sedimento posicionadas en microcanales e islas de vegetación en 5 distancias pendiente abajo a partir de la parte superior de la parcela y por el avance del frente de sedimento. La mayoría de la deposición de sedimento ocurrió dentro del primer metro pendiente abajo del punto de aplicación. En los tratamientos control y segado aproximadamente $90 \%$ del sedimento aplicado se filtró del escurrimiento dentro de $10 \mathrm{~m}$, mientras aproximadamente de 84 a $77 \%$ del sedimento aplicado fue atrapado en las parcelas de los tratamientos pisoteado y apacentado respectivamente. Las principales variables que influenciaron la filtración de sedimento fueron la densidad de tallos y la rugosidad aleatoria de la superficie. La densidad de tallos fue la variable de mayor influencia en la filtración de sedimento. El apacentamiento de ganado redujo la densidad de tallos en $\mathbf{4 0 \%}$. El monitoreo de la densidad de tallos debe ayudar a los manejadores de tierras en regular el uso de las comunidades ribereñas por el ganado y facilitar la protección de la calidad de agua superficial del sedimento en el flujo superficial.

Practice to remove sediment and other types of non-point source (NPS) pollution from overland runoff (Dillaha 1989, Magette et al. 1989). The efficiency of VFS in trapping sediment depends on the microtopography, vegetation cover and density, slope, length of the buffer strip, and the type and degree of surface disturbance (NRC 1993, Landry and Thurow 1997). Because of their location adjacent to surface waters, riparian areas often function as VFS to trap sediment derived from upland sources before it reaches the stream (Cooper et al. 1987, Osborne and Kovacic 1993, Hairsine 1996, Pearce et al. 1998b). Though livestock use has been one of 
the most important modifiers (i.e. soil compaction, defoliation, and physical damage to vegetation) of western United States riparian areas (Elmore and Beschta 1987), the effects of cattle use on sediment trapping ability of riparian filter strips have not been examined. The objectives of this study were to determine the effects of cattle trampling and grazing on vegetation and soil surface variables, and to evaluate their effects on sediment movement and filtration in a montane riparian meadow under simulated rainfall and overland flow conditions.

\section{Methods and Materials}

\section{Study Site}

Research was conducted in the summer (June-August) of 1997, in the Roosevelt National Forest approximately $80 \mathrm{~km}$ northwest of Fort Collins, Colo. at an elevation of $2,500 \mathrm{~m}$, in a riparian meadow adjacent to Sheep Creek ( $40^{\circ} 56^{\prime} 58^{\prime \prime} \mathrm{N}$ Lat., $105^{\circ} 40^{\prime} 51^{\prime \prime}$ W Long.). Dominant vegetation in the meadow included shrubby cinquefoil (Potentilla fruticosa L.), Kentucky bluegrass (Poa pratensis L.), tufted hairgrass (Deschampsia caespitosa (L.) Beauv.), small-winged sedge (Carex microptera Mack.), water sedge ( $C$. aquatilus Wahl), Baltic rush (Juncus balticus Willd.), and various forb species such as marsh marigold (Caltha leptosepala D.C.) and yarrow (Achillea lanulosa L.).

Soils within the Sheep Creek riparian area are primarily Fluvaquents. These sandy to clay loam soils have a water table that is commonly at a depth of less than 30 $\mathrm{cm}$ at some time during the spring and summer. A highly organic $(>7 \%)$ ' A' horizon, up to $20 \mathrm{~cm}$ thick, covered the study area (USDA 1980, Frasier et al. 1998).

Sixteen, 3 x 10 m plots, established during previous experiments at Sheep Creek (Fernald 1997, Pearce et al. 1998a), were used in this study. All plots had been mowed to a $10 \mathrm{~cm}$ stubble height the previous 2 summers. Paired plots ( $3 \mathrm{~m}$ apart) were delineated with $15 \mathrm{~cm}$ high steel edging placed $6 \mathrm{~cm}$ into the soil and oriented perpendicularly to Sheep Creek. A 'Swanson type' large rotating boom rainfall simulator was used to simulate an intense rainstorm over the plots (Swanson 1965, Laflen et al. 1991, Simanton et al. 1991).

\section{Treatments}

One of the following treatments was applied to each plot:
Control: Undisturbed plots with natural vegetation approximately $20 \mathrm{~cm}$ tall.

Mowed: Plots were mowed to a uniform $10 \mathrm{~cm}$ stubble height, with the clippings removed.

Trampled: Three muzzled $320 \mathrm{~kg}$ heifers (stocking rate $\approx 200$ Animal Unit Days (AUD)/ha) were placed on these plots for 8 hours (1630 to 2030 hours and 0430 to 0830 hours).

Grazed plus trampled: Three $320 \mathrm{~kg}$ heifers (stocking rate $\approx 200$ AUD/ha) were taken off feed for 12 hours and then placed on these plots for a total of 8 hours, which coincided with their normal feeding times of 1630 to 2030 hours and 0430 to 0830 hours.

The mowed treatment represented canopy reduction without hoof action. The trampled treatment was used to examine the hoof action of cattle without grazing removal of vegetation, while the grazed treatment represented the combined effects of canopy removal and hoof action.

\section{Plot Characterization}

Cover, soil microtopography (i.e., random roughness), vegetation stem density, and aboveground biomass were assessed to determine their effects on sediment movement and deposition. Whenever possible, a catwalk was used above the plots to minimize surface disturbance.

\section{Cover}

Cover by class (i.e., litter, bare ground, forbs, grasses, and shrubs) at the soil surface was determined with a 10 point pin frame before treatment (adapted from Hofmann et al. 1983, Devaurs and Gifford 1984). Ten random pin frames (i.e., 100 points) within each plot were taken. The plots were sampled again after the posttreatment rainfall simulation.

\section{Random Roughness}

Surface microtopography was measured with a 100 point $(10 \times 9.6 \mathrm{~cm}$ grid $)$ elevation pin table $(0.6 \times 2 \mathrm{~m})$, positioned lengthwise across the center of each plot (Linse et al. 2001). Pin height ( $\mathrm{mm}$ ) above the table was measured with a digital caliper. The standard deviation of all 100 pin elevations was used as an index of surface random roughness (Hairsine et al. 1992, Frasier et al. 1998).

\section{Vegetation}

Vegetation density (stems $\mathrm{m}^{-2}$ ) was determined by class (i.e., grasses, forbs, sedges, and Baltic rush) at ground level using a $100 \mathrm{~cm}^{2}$ quadrat. Stems within each quadrat were counted at 10 random locations within the lower $2 / 3$ of each plot before all treatments and following the cattle grazing and trampling treatments. Stem density was assumed to remain constant on the control and mowed plots; therefore, stem density was only sampled prior to treatments on these plots.

Vegetation was clipped to ground level in $1 / 8 \mathrm{~m}^{2}$ circular quadrats and bagged to estimate aboveground biomass. Five biomass samples were clipped at random locations in each plot before and after grazing, after mowing, and in the control plot. The trampled treatment was only sampled prior to treatment. Samples were dried in a forced air oven at $50^{\circ} \mathrm{C}$ for 72 hours prior to weighing.

\section{Rainfall Simulations}

Two simulation runs, approximately 24 hours apart, were made on each plot pair; one before (pre-conditioning) and one after the treatments were applied. Rainfall was simulated at an approximate rate of $100 \mathrm{~mm} \mathrm{hour}^{-1}$. This amount of simulation water applied was almost double that used in previous studies at Sheep Creek by Fernald (1997) and Pearce et al. (1998a), and was chosen, not to duplicate natural storm events, but to provide adequate flow to move sediment. Actual rainfall application rate of the simulator was measured with a $20 \mathrm{~cm}$ diameter rain gage equipped with a bubble gage recorder positioned between the paired plots. Distribution of total simulated rainfall was measured with 6 small plastic rain gages randomly located within each plot border (Frasier et al. 1998).

Overland flow during pre- and posttreatment runs was simulated by spraying water at a rate equivelent to $25 \mathrm{~mm}^{-1}$ over the entire plot onto a $3.0 \times 0.6 \mathrm{~m}$ tilted ( $6 \%$ slope) tray at the upper edge of each plot. Actual application rate was determined for each simulation run by volumetric sampling of the spray bar nozzles. Runoff was measured at the bottom of each plot with a calibrated flume attached to a pressure transducer bubble gage recorder. Discharge was recorded at $1 \mathrm{~min}$ intervals.

\section{Pre-treatment Rainfall Simulation}

Plots were preconditioned for 1 hour with simulated rainfall and overland flow, 24 hours prior to treatment. Once steady- 
state (equilibrium) runoff was achieved, a dye tracer was applied as a line source across the plots at 2 locations ( 3 and $6 \mathrm{~m}$ downslope from the top of the plots) to delineate microchannel flow paths and rate of water front advancement down the plots. Flow channels were delineated with spray paint for placement of sediment traps before the post-treatment simulation event.

\section{Post-treatment Rainfall Simulation}

Following treatment, rainfall plus overland flow was again simulated over paired plots. When equilibrium runoff was achieved, sediment of known particle size was introduced to overland flow on each plot at a rate of $3 \mathrm{~kg}$ every $2 \mathrm{~min}$. A total of $60 \mathrm{~kg}\left(\approx 20,000 \mathrm{~kg} \mathrm{ha}^{-1}\right)$ of sediment was applied. This rate was selected based on previous overland flow studies at Sheep Creek where $30 \mathrm{~kg}\left(\approx 10,000 \mathrm{~kg} \mathrm{ha}^{-1}\right)$ of sediment was applied (Pearce et al. 1998a, 1998b). Reported levels of sediment that might reach a riparian area in overland flow are usually considerably less $(\approx 5,000$ $\left.\mathrm{kg} \mathrm{ha}^{-1}\right)$ than the amount used in this study (Buckhouse and Mattison 1980, Buckhouse and Gaither 1982). The introduced sediment was white and mixed by weight from 2 commercial ground silica products, $60 \%$ SIL-CO-SIL ${ }^{\circledR} 250$ and $40 \%$ MIN-USIL ${ }^{\circledR} 5$, with a particle size distribution of $31.6 \%$ very fine sand (> $50 u \mathrm{~m}$ ), $41.8 \%$ silt $(2-50 u \mathrm{~m})$ and $26.6 \%$ clay $(<2 u \mathrm{~m})$. This sediment had a higher portion of fines $(<50 u \mathrm{~m})$ than the soils on the uplands in the Sheep Creek area and thus, would be more easily moved by the water (Pearce et al. 1998a).

A total of 15 runoff samples were collected at the base of each plot for sediment yield determination. Beginning with the onset of equilibrium runoff, eleven, 950 $\mathrm{ml}$ grab samples of runoff were taken at 4 min intervals. When the simulator was shut off, discharge decreased, and the remaining 4 runoff samples were $500 \mathrm{ml}$ each. Each runoff sample was filtered through pre-weighed high wet strength 15 $\mathrm{cm}$ diameter filter paper with pore diameters of $1 \mu \mathrm{m}$. The samples were dried in a forced draft oven at $50^{\circ} \mathrm{C}$ for 4.5 hours and re-weighed. Sediment concentration was determined for each sample and these data were correlated with discharge measurements to arrive at an estimated total sediment yield for each plot within each treatment. Only negligible amounts of organic residues were collected in runoff samples (McEldowney 1999).

Table 1. Responses of selected variables for 4 treatments applied to a montane riparian meadow. Similar letters following means in a row indicate non-significant differences $(P>0.10)$.

\begin{tabular}{lllll}
\hline \hline & \multicolumn{4}{c}{ Treatment } \\
\cline { 2 - 5 } Variable & Control & Mowed & Trampled & Grazed \\
\hline Plot slope (\%) & $3.8 \mathrm{a}$ & $3.6 \mathrm{a}$ & $4.2 \mathrm{a}$ & $3.8 \mathrm{a}$ \\
Litter cover $(\%)$ & $63 \mathrm{a}$ & $65 \mathrm{a}$ & $61 \mathrm{a}$ & $62 \mathrm{a}$ \\
Stem density (\# stems $\left.\mathrm{m}^{-2}\right)$ & $5,300 \mathrm{ab}$ & $5,500 \mathrm{a}$ & $4,700 \mathrm{~b}$ & $3,300 \mathrm{c}$ \\
Random roughness $(\mathrm{mm})$ & $13.0 \mathrm{a}$ & $11.9 \mathrm{a}$ & $12.4 \mathrm{a}$ & $13.6 \mathrm{a}$ \\
Aboveground biomass $\left(\mathrm{kg} \mathrm{ha}^{-1}\right)$ & $2,300 \mathrm{a}$ & $1,700 \mathrm{a}$ & - & $900 \mathrm{~b}$ \\
Coarse particle movement $(\mathrm{mm})$ & $726 \mathrm{~b}$ & $733 \mathrm{~b}$ & $971 \mathrm{~b}$ & $1,279 \mathrm{a}$ \\
Sediment filtration* $\left(\mathrm{kg} \mathrm{ha}^{-1}\right)$ & $19,600 \mathrm{a}$ & $19,800 \mathrm{a}$ & $18,700 \mathrm{a}$ & $17,300 \mathrm{~b}$ \\
\hline
\end{tabular}

$* 20,000 \mathrm{~kg} \mathrm{ha}^{-1}$ of sediment applied to all plots.

\section{Sediment Movement}

Sediment transport and deposition was determined using 5 rows of 4 sediment traps at $1,1.5,2.0,2.5$, and 3.0 m downslope from the top of each plot. Two traps in each row were placed within microchannels and 2 in vegetation 'islands' between microchannels. Sediment traps were plastic cups, $6.2 \mathrm{~cm}$ diameter at the top and $7.5 \mathrm{~cm}$ tall. The traps were placed with their tops flush with the soil surface. Sediment caught in the 2 channel traps or the 2 island traps within a row was composited by location and was later vacuum filtered, dried and weighed. The maximum distance that coarse particles traveled was visually estimated and measured from the top of each plot after the rainfall simulation.

\section{Experimental Design}

The 4 treatments were organized in a randomized complete block design with 4 blocks that were on an aridity gradient perpendicular to the stream. A repeated measures analysis of variance was used to determine differences among treatments and between sediment trap position (in or out of microchannels) and distance downslope. Sediment trap data were transformed to $\log _{10}$ scale before analysis, but results are reported as actual values. Analysis of covariance was used to determine relationships among treatments, vegetation characteristics, soil microtopography, and flow parameters with coarse particle sediment movement. Sediment yield was analyzed to determine treatment effects $(P \leq 0.10)$. Multiple regression models were constructed for sediment trap data and sediment yield by treatment using a forward selection process, and for coarse particle movement using a backward selection process. Significance was accepted at $\mathrm{P} \leq$ 0.10 . Data are presented as main effects unless there was a significant interaction. Data analyses were done using $\mathrm{SAS}^{\circledR}$ for Windows ${ }^{\circledR}\left(\right.$ SAS $\left.^{\circledR} 1996\right)$.

\section{Results and Discussion}

\section{Cover}

Cover (live + litter) was greater than $96 \%$ on all plots. Litter was the dominant ground cover (61 to $65 \%$ ) for all treatments, with no differences among treatments (Table 1). Ground cover classes such as sedges, moss, and forbs also were not affected by treatments. The large amount of litter likely reduced soil compaction and alterations to the soil surface that may have been caused by hoof action of the heifers.

\section{Random Roughness}

Random roughness of the soil surface was similar among treatments (Table 1). In North Dakota, Hofmann and Ries (1991) determined there were no differences in surface roughness among their grazed and ungrazed treatments. Their index of surface roughness was the variance from 10 pin elevations spaced $50 \mathrm{~mm}$ apart. Frasier et al. (1998) found no differences in surface random roughness among stubble height treatments for riparian communities, and concluded that surface random roughness was very difficult to adequately characterize. As several authors have suggested (Linse 1992, Fernald 1997, Frasier et al. 1998, Pearce et al. 1998b), the connectivity of microtopographical features may be more important for water routing than is random roughness itself.

\section{Vegetation}

Cattle grazing decreased stem density by $40 \%$ compared to the control (Table 1 ). Specifically, forb stem densities were decreased by $50 \%$ on both trampled and grazed plus trampled treatments, as compared to the control. Grass stem densities were reduced approximately $40 \%$ on the grazed plots compared to the control. The grazed (plus trampled) treatment had the lowest average stem density, because cattle removed stems by both pulling up 


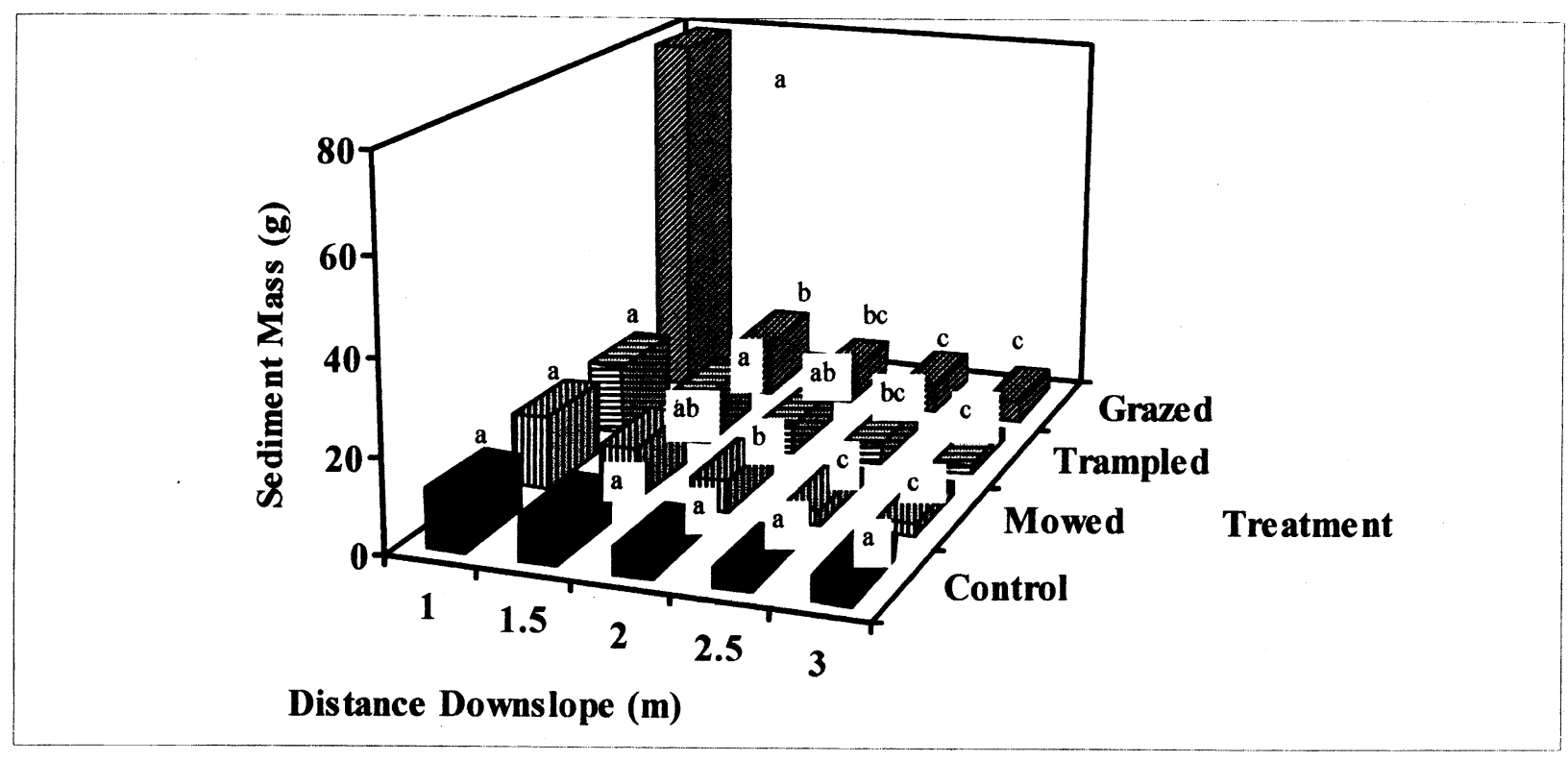

Fig. 1. Sediment deposition in traps positioned within microchannels. Comparison of distances done separately within each treatment. Values within the same position with the same letter are not significantly different $(P>0.10)$.

stems with grazing and through hoof shear (Kauffman et al. 1983, Abdel-Magid et al. 1987). These differences imply that, under these very wet soil conditions, the relative impact of hoofs is less on changing plant stem density than the actual animal grazing. The reduction in stem density following the cattle treatments subsequently impacted microchannel, runoff, and sediment movement characteristics (Flenniken et al. 2001).

Aboveground biomass was approximately $60 \%$ less on grazed plots than on control plots. However, there were no significant differences between mowed and grazed plots for aboveground biomass (Table 1). Forage utilization of grazed plots ranged from 12 to greater than $75 \%$, with a mean utilization level of $54 \%$.

\section{Sediment Traps}

Analysis of sediment trap data indicated a significant 3-way interaction among treatments, position (in channels vs. on islands), and distance downslope. On grazed plots, there was almost 4 times the amount of sediment in channel traps placed $1 \mathrm{~m}$ downslope than at the next distance $(1.5 \mathrm{~m})$ downslope (Fig. 1). The large difference between the amount of sediment caught within this half meter distance may have resulted from insufficient energy in microchannel flow to transport sediment beyond $1 \mathrm{~m}$ downslope.

The greater quantity of sediment trapped in channels in the first meter of the grazed plots resulted from differences in both vegetation and flow characteristics. Cattle grazing reduced vegetation barriers to sediment movement that were present on the trampled, mowed, and control treatments. With less sediment trapped within the vegetation, there was more sediment available to be transported and deposited in the microchannels. Additionally, with less vegetative cover, sediment was subjected to raindrop splash and transport phenomena into the channel traps (Thurow et al. 1986). Microchannel sinuosity was also decreased on the grazed plots (Flenniken et al. 2001), which may have increased the transport capacity of sediments in channels to the traps within the first meter of the grazed plots.

On the mowed and trampled plots most of the sediment in the microchannels was trapped in the top 1-2 m. On the trampled plots more sediment was trapped within the first $1 \mathrm{~m}$ to $1.5 \mathrm{~m}$ distances downslope than at $2.5 \mathrm{~m}$ and $3 \mathrm{~m}$ positions (Fig. 1). On mowed plots there was more sediment in the microchannel traps in the first meter than at $2,2.5$, or $3 \mathrm{~m}$ downslope. In contrast, there were no significant differences in the amounts of sediment caught in traps positioned in microchannels at any distance downslope for the control plots.

The general trend that more sediment was caught in traps positioned in microchannels than in islands for each treatment was expected since microchannels were topographically lower and carried the majority of flow (Fig. 1 and 2). The greater mass of sediments that moved in microchannels was a result of increased overland flow transport capacity that resulted from increased flow velocity and depth in microchannels than in interspace areas (Rogers and Schumm 1991, Flenniken 1999). More sediment was caught in island traps at the $1 \mathrm{~m}$ distance than at 2.5 or $3 \mathrm{~m}$ distances (Fig. 2). The presence of sediment in island traps may have resulted from particle movement into traps from raindrop splash detachment, and from overland flow in areas where the flow was deep enough to submerge traps on vegetation islands. Vegetated filter strips have been shown to become less effective once overland flow depth exceeds vegetation height (Pearce et al. 1997). If vegetation height is greatly decreased by cattle grazing and trampling, then overland flow depths may exceed the height of the vegetation.

\section{Coarse Particle Movement}

Greater downslope coarse particle (sand) movement occurred on the grazed treatment than on the trampled, mowed, or control treatments (Table 1). However, there were no significant differences in sand movement among these 3 other treatments. Sand moved $78 \%$ farther downslope from the upper edge of grazed plots as compared with control plots. Since coarse particle movement downslope on grazed plots was greater than on trampled plots, this indicated that grazing removal of canopy cover and stems was more important than the effect of trampling alone. Variables that most influenced the 


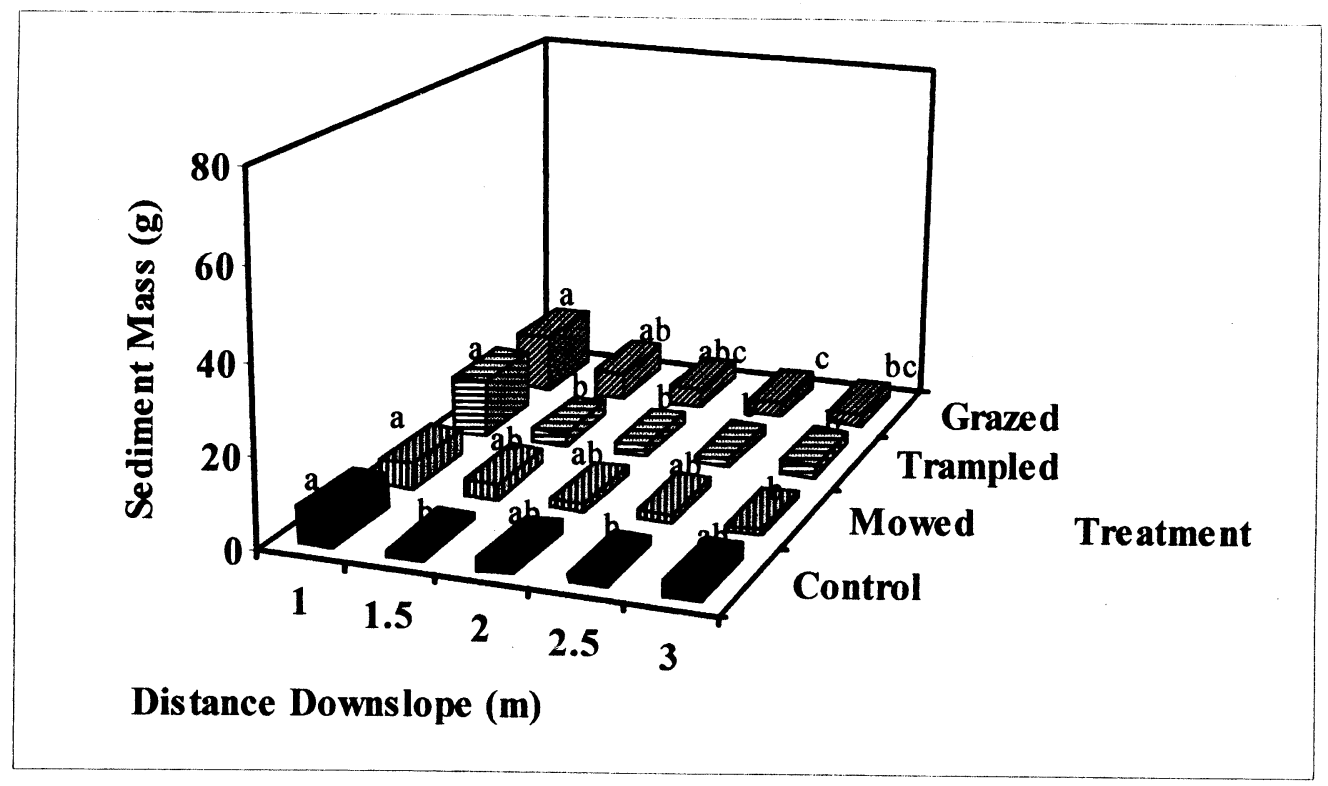

Fig. 2. Sediment deposition in traps positioned on islands between microchannels. Comparison of distances done separately within each treatment. Values within the same position with the same letter are not significantly different $(P>0.10)$.

downslope movement of coarse sediment were stem density and microchannel flow velocity (Table 2 ).

\section{Sediment Filtration}

Sediment filtration in the grazed treatment was significantly lower than in the trampled, mowed, or control treatments, which were not different from one another (Table 1). Simulated trampling studies have been conducted elsewhere to evaluate the effects of trampling on sediment yield. Packer (1953) found that increased trampling generally caused increased soil loss. However, simulated trampling had no effect on soil loss when initial ground cover was over $90 \%$. In another simulated trampling experiment, Dadkhah and Gifford (1980) showed that grass cover was the most important variable affecting sediment yield, regardless of trampling level. They recommended the maintenance of $50 \%$ ground cover for watershed protection for sites with loamy soil and $15 \%$ slopes.

Stem density was the primary variable that affected total sediment yield in the present study. Sixty four percent of the measured variability in sediment yield

Table 2. Predictive models for sediment movement and sediment yield in a montane riparian meadow.

\begin{tabular}{llr}
\hline \hline Dependent variable & Independent variables and regression equation & $\mathrm{r}^{2}$ \\
\hline Coarse particle movement & & \\
downslope $(\mathrm{mm})$ & $1267.11-0.015\left(\right.$ stems m$\left.^{-2}\right)+9175.86\left(\right.$ flow velocity $\left.\mathrm{m} \mathrm{sec}^{-1}\right)$ & 0.59 \\
Sediment yield $\left(\mathrm{kg} \mathrm{ha}^{-1}\right)$ & $9778.1-0.998\left(\right.$ stems m$\left.^{-2}\right)-171.14$ surface roughness index $(\mathrm{mm})$ & 0.78 \\
\hline
\end{tabular}

among treatments was accounted for by stem density alone. Surface random roughness values were poor estimators of sediment yield when used alone. However, when used in conjunction with stem density, random roughness improved our ability by $14 \%$ to predict sediment yield (Table 2 ). Both of these factors exert friction on overland flow.

The interaction between discharge and bed friction directly influences sediment transport; as discharge increases, the energy available to carry sediment also typically increases. Several studies have shown the importance of friction created by stem density as it affects overland flow. Fernald (1997) found that an effective friction subfactor, that was derived from stem width to stem spacing ratio, better estimated discharge than did plot averaged friction subfactors or microchannel effective friction subfactors based on ground cover class, soil texture, and standing plant biomass. A field flume study conducted by Prosser et al. (1995) showed that critical shear stress was reduced by half when grass was clipped to a $10 \mathrm{~cm}$ stubble height, but that rates of sediment transport were still very low. With complete removal of plant stems, critical shear stress was reduced to $11-38 \%$ of control plot values. This allowed more sediment to be transported on clipped plots. Prosser et al. hypothesized that 2 flow regimes existed once herbaceous vegetation was overwhelmed by water; a slower flow through vegetation stems with a more rapid laminar flow above them. This shear stress partitioning suggested that on a densely grassed surface, more than $90 \%$ of the resistance to flow was caused by plant stems (Prosser et al. 1995). In a small plot study in Arizona, Abrahams et al. (1994) determined that plant stems and litter cover were the primary variables that created resistance to overland flow on grassland plots clipped to a height of 2 to $3 \mathrm{~cm}$.

Results from this present experiment supported findings of Pearce et al. (1997, 1998a, 1998b) that stubble height was not a good indicator for sediment filtration in a montane riparian community. Pearce et al. (1998a, 1998b) determined that sediment yield neither decreased nor increased as vegetation stubble height increased, as water flow depth was less than the height of the stubble. They concluded that accurate prediction of sediment filtration from overland flow required the consideration of a combination of vegetation and soil surface variables such as stem density, forb cover, amount of bare ground, silt content of soil, clay content of introduced sediment, amount of runoff, and slope.

Variables that were considered in this present study, but had little effect on sediment yield or became insignificant when considered simultaneously with stem den- 
sity, were bare ground, litter cover, moss cover, microchannel sinuosity, drainage density, and rainfall intensity. Because both the amount and type of ground cover among treatments were similar, and probably caused analogous turbulent flows at the soil-water interface, the influence of ground cover on sediment yield was similar for all 4 treatments. There can be no doubt of the importance of ground cover to sediment transport, but when ground cover is similar among treatments the influence of other variables, such as stem density, is dominant.

Increased microchannel sinuosity can also influence sediment yield (Thurow et al. 1988, Spaeth et al. 1994, Prosser et al. 1995 ) by reducing flow velocity, thus reducing sediment transport capacity. In a companion study to ours, short durationhigh intensity cattle trampling resulted in a reduction of microchannel sinuosity (Flenniken et al. 2001). This reduction, however, did not explain as much variability in sediment yield as did stem density.

At the watershed scale, drainage density and sediment yield are typically thought to be negatively correlated with vegetaion cover and positively correlated with maximum precipitation events (Abrahams 1972, Dunne and Leopold 1978). At the scale of this present study, cattle trampling and grazing resulted in a decrease in drainage density (Flenniken 1999) and an increase in sediment yield (McEldowney 1999). A few larger microchannels with greater flows should result in increased sediment transport. A good correlation between sediment yield and drainage density, however, was not found. The decrease in drainage density on the cattle disturbed plots may indicate a homogenization effect by cattle on spatial variability of the vegetation. Additional research is needed to determine spatial variability of vegetation in riparian areas as it affects sediment filtration.

Canopy removal by cattle or by mowing may have permitted more raindrops to strike the sediment laden overland flow, and thereby facilitate the movement of sediment downslope. Rainfall intensity over the very narrow range experienced in this study had little effect on total sediment yield. However, splash resulting from raindrop impact could have transported sediment laden drops short distances (both up- or down-hill), such as into the island sediment cups. Most of the plot area was covered with a layer of water during equilibrium runoff that ranged in depth from 14 to $36 \mathrm{~mm}$ (Flenniken 1999), and likely reduced rain- drop impact sufficiently to nullify the effect of rainfall intensity on sediment reentrainment (Hairsine et al. 1992). Moss (1988) found that raindrop impact on turbulent flow was minor and had little effect on sediment transport. He found that raindrop impact was most important in reentrainment of bedload size $(0.2 \mathrm{~mm})$ particles. Because of the relatively low energy required to transport fine particles such as silt and clay (suspended load), raindrop impact would probably not affect their transport.

\section{Conclusions}

Studies where sediment movement as affected by cattle activity and differences in sediment movement in channels versus islands could not be found. However, there are studies that have shown that vegetation height was less influential than canopy cover in reducing downslope sediment movement (Pearce et al. 1998a). Down slope coarse particle movement did not differ between control and mowed treatments in this present study. These results agreed with Pearce et al. (1998a) who determined that there were no differences in sand movement between $10 \mathrm{~cm}$ stubble height and natural vegetation height (about $22 \mathrm{~cm}$ ) treatments in a grass/sedge community.

Treatment, positioning of traps in channels or islands, and distance downslope were all significant factors that affected sediment deposition in traps. Sediment traps were used in this study as indicators of sediment transport, not sediment retention. Therefore, the greater mass of sediment caught in traps on grazed plots positioned in channels at $1 \mathrm{~m}$ downslope compared with the other 4 distances reflected greater transport of sediment on these plots. Lower vegetation stem density and aboveground biomass on grazed plots reduced the ability of these plots to retain sediment and allowed transport of sediment into channel traps. Microchannels in riparian areas act as conduits to transport sediment downslope. The straightening and reduction in density of these microchannels that resulted from cattle grazing caused deeper flow depths and increased flow velocities. These straighter and deeper microchannels then had greater sediment transport capacity and sediment movement downslope (Flenniken et al. 2001).

Sediment filtration was less in both the grazed $(77 \%)$ and trampling $(84 \%)$ treat- ments as compared with control and mowed treatments where sediment filtration was about $90 \%$. These filtration values were slightly less than those found by Pearce et al. (1998b) for the same montane community. In that study, both the rainfall intensity $\left(85 \mathrm{~mm} \mathrm{hr}^{-1}\right)$ and the amount of sediment that was added to the plots $(30 \mathrm{~kg})$ were both significantly lower than in this present study.

The density of herbaceous plant stems was the most important variable that affected sediment filtration in this present study. As stem density increased, so did sediment filtration. Cattle grazing not only reduced the height of vegetation, but stem density was decreased as well. This caused stubble height alone to be a poor predictor of sediment filtration in areas grazed by cattle. Friction provided by more dense plant stems on both the mowed and control treatments attenuated overland flow velocities and increased sediment deposition (Flenniken et al. 2001). In addition, use of the standard deviation for surface random roughness quantification also improved the prediction model for sediment yield.

Under the extreme conditions of this study (i.e., intense rainfall, high sediment loading, and high stocking rate of cattle), stem densities of approximately 5,000 stems $\mathrm{m}^{-2}$ were effective in trapping $90 \%$ of the sediment applied. In areas where riparian filtration of NPS pollution is a primary management goal, monitoring of stem density could be an important tool in the decision making process. Results of this research supported the findings of other studies (Lowrance et al. 1986, Cooper et al. 1987, Welsch 1991, Daniels and Gilliam 1996, Hairsine 1996, Pearce et al. 1998b) that indicated that riparian filtration could be effective for reducing NPS pollution to surface waters. In addition, our findings indicated that properly managed cattle grazing along the outer edges of montane riparian meadows might be compatible with sediment filtration goals.

The importance of stem density in this montane riparian community for sediment filtration indicates that stem density data might be useful in modeling sediment transport. Furthermore, this research has demonstrated the necessity to consider riparian areas separately from adjacent uplands. If this is done, improved estimates of sediment delivery to a stream or lake should result. 


\section{Literature Cited}

Abdel-Magid, A.H., M.J. Trlica, and R.H. Hart. 1987. Soil and vegetation responses to simulated trampling. J. Range Manage. 40:303-306.

Abrahams, A.D. 1972. Drainage densities and sediment yields in Eastern Australia. Aust. Geo. Studies 10:19-41.

Abrahams, A.D., A.J. Parsons, and J. Wainwright. 1994. Resistance to overland flow on semiarid grassland and shrubland hillslopes, Walnut Gulch, southern Arizona. J. Hydrol. 156:431-446.

Buckhouse, J.C. and R.E. Gaither. 1982. Potential sediment production within vegetative communities in Oregon's Blue Mountains. J. Soil and Water Cons. $37: 120-122$.

Buckhouse, J.C. and J.L. Mattison. 1980. Potential soil erosion of selected habitat types in the High Desert Region of central Oregon. J. Range Manage. 33:282-285.

Cooper, J.R., J.W. Gilliam, R.B. Daniels, and W.P. Robarge. 1987. Riparian areas as filters for agricultural sediment. Soil Sci. Soc. Amer. J. 51:416-420.

Dadkhah, M. and G.F. Gifford. 1980. Influence of vegetation, rock cover, and trampling on infiltration rates and sediment production. Water Resour. Bull. 16:979-986.

Daniels, R.B. and J.W. Gilliam. 1996. Sediment and chemical load reduction by grass and riparian filters. Soil Sci. Soc. Amer. J. 60:246-251.

Devaurs, M. and G.F. Gifford. 1984. Variability of infiltration within large runoff plots on rangelands. J. Range Manage. 37:523-528.

Dillaha, T.A. 1989. Water quality impacts of vegetative filter strips. Paper No. 89-2043. Am. Soc. Agr. Eng. St. Joseph, Mich. 9 p.

Dunne, T. and L.B. Leopold. 1978. Water in Environmental Planning. W.H. Freeman and Co. New York. 818 p.

Edwards, W.M. and L.B. Owens. 1991. Large storm effects on total soil erosion. J. Soil and Water Cons. 46:75-78.

Elmore, W. and R.L. Beschta. 1987. Riparian areas: perceptions in management. Rangelands 9:260-266.

Fernald, A.G. 1997. Microtopographic flow paths and riparian surface hydrology. Ph.D. Diss. Colorado State Univ. Fort Collins, Colo. $136 \mathrm{p}$.

Flenniken, M. 1999. Flow characteristics and sediment movement in a montane riparian ecosystem. M.S. Thesis. Colorado State Univ. Fort Collins, Colo. 99 p.

Flenniken, M., R. McEldowney, G.W. Frasier, W.C. Leininger, and M.J. Trlica. 2001. Runoff response in a montane riparian area following cattle use. J. Range Manage. 54:567-574.

Frasier, G.W., M.J. Trlica, W.C. Leininger, R.A. Pearce, and A. Fernald. 1998. Runoff from simulated rainfall in 2 montane riparian communities. J. Range Manage. 51:315-322.
Hairsine, P.B. 1996. Comparing grass filter strips and near-natural riparian zones for trapping sediment and sorbed nutrients. p. 109. In: Paper presented at ASSSI and NZSSS National Soils Conference, July 1996 - Oral paper.

Hairsine, P.B., C.J. Moran, and C.W. Rose. 1992. Recent developments regarding the influence of soil surface characteristics on overland flow and erosion. Aust. J. Soil Res. 30:249-264.

Hofmann, L. and R.E. Ries. 1991. Relationship of soil and plant characteristics to erosion and runoff on pasture and range. J. Soil and Water Cons. 46:143-147.

Hofmann, L., R.E. Ries, and J.E. Gilley. 1983. Relationship of runoff and soil loss to ground cover of native and reclaimed grazing land. Agron. J. 75:599-602.

Kauffman, J.B., W.C. Krueger, and M. Vavra. 1983. Effects of late season cattle grazing on riparian plant communities. J. Range Manage. 36:685-690.

Laflen, J.M., L.J. Elliot, J.R. Simanton, C.S. Holzhey, and K.D. Kohl. 1991. WEPP Soil erodibility experiments for rangeland and cropland soils. J. Soil and Water Cons. 46:39-44.

Landry, M.S. and T.L. Thurow. 1997. Function and design of vegetation filter strips: An annotated bibliography. Texas State Soil and Water Conservation Board Bull. No. 97-1. Temple, Tex.

Larson, W.E., M.J. Lindstrom, and T.E. Schumacher. 1997. The role of severe storms in soil erosion: a problem needing consideration. J. Soil and Water Cons. 52:90-95.

Linse, S.J. 1992. The influence of ground cover on upland range erosion. M.S. Thesis. Univ. Wyoming. Laramie, Wyo. 98 p.

Linse, S.J., D.E. Mergen, J.L. Smith, and M.J. Trlica. 2001. Upland erosion under a simulated most damaging storm. J. Range Manage. 54:356-361.

Lowrance, R., J.K. Sharpe, and J.M. Sheridan. 1986. Long-term sediment deposition in the riparian zone of a coastal plain watershed. J. Soil and Water Cons. 41:266-271.

Magette, W.L., R.B. Brinsfield, R.E. Palmer, and J.D. Wood. 1989. Nutrient and sediment removal by vegetated filter strips. Trans. Am. Soc. Agr. Eng. 32:663-667.

McEldowney, R.R. 1999. Montane riparian surface hydrology and sediment filtration as affected by cattle disturbance. M.S. Thesis. Colorado State Univ., Fort Collins, Colo. 163 p.

Moss, A.J. 1988. The effects of flow-velocity variations on rain-driven transportation and the role of rain impact in the movement of solids. Aust. J. Soil Res. 26:443-450.

National Research Council (NRC). 1993. Soil and Water Quality: An Agenda for Agriculture. National Academy Press. Washington, D.C. $516 \mathrm{p}$.

Novotny, V. and H. Olem. 1994. Water Quality: Prevention, Identification, and Management of Diffuse Pollution. Van Nostrand Reinhold. New York. 1054 p.
Osborne, L.L. and D.A. Kovacic. 1993. Riparian vegetated buffer strips in water quality restoration and stream management. Freshwater Bio. 29:243-250.

Packer, P.E. 1953. Effects of trampling disturbance on watershed condition, runoff, and erosion. J. Forestry 51:28-31.

Pearce, R.A., M.J. Trlica, W.C. Leininger, D.E. Mergen, and G. Frasier. 1998a. Sediment movement through riparian vegetation under simulated rainfall and overland flow. J. Range Manage. 51:301-308.

Pearce, R.A., M.J. Trlica, W.C. Leininger, J.L. Smith, and G.W. Frasier. 1997. Efficiency of grass buffer strips and vegetation height on sediment filtration in laboratory rainfall simulations. J. Environ. Qual. 26:139-144.

Pearce, R.A., G.W. Frasier, M.J. Trlica, W.C. Leininger, J.D. Stednick, and J.L. Smith. 1998b. Sediment filtration in a montane riparian zone under simulated rainfall and overland flow. J. Range Manage. 51:309-314.

Prosser, I.P., W.E. Dietrich, and J. Stevenson. 1995. Flow resistance and sediment transport by concentrated flow in a grassland valley. Geomorphology 13:71-86.

Rogers, R.D. and S.A. Schumm. 1991. The effect of sparse vegetation cover on erosion and sediment yield. J. Hydrol. 123:19-24.

SAS. 1996. SAS System for Windows Version 6.12. Cary, N.C.

Simanton, J.R., M.A. Weltz, and H.D. Larsen. 1991. Rangeland experiments to parameterize the water erosion prediction project model: vegetation canopy effects. J. Range Manage. 44:276-282.

Spaeth, K.E., M.A. Weltz, H.D. Fox, and F.B. Pierson. 1994. Spatial pattern analysis of sagebrush vegetation and potential influences on hydrology and erosion. pp. 35-50. In: W.H. Blackburn, F.B. Pierson, G.E. Schumann, and R. Zartman (eds.) Variability in Rangeland Water Erosion Processes. SSSA Special Pub. No. 38. Madison, Wisc

Swanson, N.P. 1965. Rotating-boom rainfall simulator. Trans. Amer. Soc. Agr. Eng. 8:71-72.

Thurow, T.L., W.H. Blackburn, and C.A. Taylor, Jr. 1986. Hydrologic characteristics of vegetation types as affected by livestock grazing systems, Edwards Plateau, Texas. J. Range. Manage. 39:505-509.

Thurow, T.L., W.H. Blackburn, and C.A. Taylor, Jr. 1988. Infiltration and interrill erosion responses to selected livestock grazing strategies, Edwards Plateau, Texas. J. Range Manage. 41:296-302.

USDA, Soil Conservation Service and Forest Service. 1980. Soil survey report. Larimer County, CO. U.S. Govt. Print. Off. 239-812/48. Washington, D.C.

Welsch, D.J. 1991. Riparian Forest Buffers: Function and Design for Protection and Enhancement of Water Resources. USDA Forest Serv. NA-PR-07-91. Radnor, Penn. $24 \mathrm{p}$. 


\title{
Calibrating fecal NIRS equations for predicting botanical composition of diets
}

\author{
JOHN W. WALKER, SCOTT D. MCCOY, KAREN L. LAUNCHBAUGH, MERRITA J. FRAKER, AND JEFF POWELL
}

Authors are Resident Director of research, Texas Agricultural Experiment Station, San Angelo, Tex. 76901; Research Technician, USDA U. S. Sheep Experiment Station, Dubois, Ida. 83423; Assistant Professor, University of Idaho, Moscow, Ida, 83844; Research Associate, Montana State University, Bozeman, Mont. 59717; and Professor, University of Wyoming, Laramie Wyo. 82071.

\section{Abstract}

The objectives of this study were to investigate the use of near infrared spectroscopy (NIRS) of fecal samples for predicting the percentage of mountain big sagebrush (Artemisia tridentata Nutt. ssp. vaseyana (Rydb) Beetle) in sheep diets and to quantify the limitations of using NIRS of fecal samples to predict diet composition. Fecal material from a sheep feeding trial with known levels of sagebrush and several background forages was used to develop fecal NIRS calibration equations validated with fecal material from 2 other sheep feeding trials with known levels of sagebrush in the diets. The 1996 calibration trial varied the level of sagebrush, alfalfa, and grass hay in the diets. The 1998 trial compared frozen to air-dried sagebrush. The Wyoming trial was a metabolism study using frozen sagebrush. Trials used different levels of sagebrush varying from 0 to $30 \%$ of the diet in increments of 4 to 10 percentage points. Internal validation of the 1996 trial with a subset of the samples not used for calibration showed that when predicted samples are from the same population as the calibration samples, this procedure can accurately predict percent sagebrush $\left(R^{2}=0.96, S E P=1.6\right)$. However, when predicted samples were from a different population than calibration samples, accuracy was much less, but precision was not affected greatly. Low accuracy was caused by a compression of the range of data in the predicted values compared to the reference values, and the predicted sagebrush levels in the diet should be considered to represent an interval scale of measurement. Modified partial least squares regression resulted in better calibration than stepwise regression, and calibration data sets with only high, low, and no sagebrush resulted in calibrations almost as good as data sets with several intermediate levels of sagebrush. High values of the $H$ statistic were related to low precision but did not affect the accuracy of predictions. We believe the interval scale of measurement will contain sufficient information for the purpose of addressing many questions on rangelands.

Key Words: Artemisia, diet selection, sagebrush, sheep

Since the initial report of using near infrared spectroscopy (NIRS) of fecal material to predict nutritional parameters of grazing animals (Coleman et al. 1989), the use of this procedure has expanded rapidly. The NIRS of feces can accurately predict dietary crude protein, digestible organic matter (Lyons and Stuth

Manuscript accepted 16 Sept. 2001.

\section{Resumen}

El objetivo de este estudio fué investigar el uso de la Espectroscopía de Reflectancia en el Infrarrojo Cercano (NIRS) en muestras de heces fecales para predecir el porcentaje de Artemisa Grande de la Montaña (Artemisia tridentata ssp. vaseyana [Rydb.] Beetle) en dietas de borregos y para cuantificar las limitaciones del uso de Espectroscopía de Reflectancia en el Infrarrojo Cercano en muestras fecales para predecir la composición de la dieta. Se usaron heces fecales de borregos bajo dietas con niveles conocidos de artemisa y varios forrajes complementarios para calibrar las ecuaciones de Espectroscopía de Reflectancia en el Infrarrojo Cercano, las cuales se validaron con material fecal de otros dos ensayos nutricionales en borregos con niveles conocidos de artemisa en las dietas. En el ensayo de calibración de 1996 los niveles de artemisa, alfalfa y paja de pasto en las dietas variaron. En el ensayo de 1998 se comparó artemisa congelada y artemisa secada al aire. El ensayo de Wyoming fué un estudio de metabolismo en el que se uso artemisa congelada. En los ensayos se usaron niveles del 0 al $30 \%$ de artemisa en la dieta con incrementos de 4 a 10 puntos porcentuales. La validación interna del ensayo de 1996 con un subgrupo de muestras no usadas para la calibración mostro que cuando las muestras predecidas eran de la misma población que las muestras de calibración, este procedimiento puede predecir correctamente el porcentaje de artemisa $\left(R^{2}=0.96, S E P=1.6\right)$. Sin embargo cuando las muestras predecidas provenían de una población diferente a las muestras de calibración, la exactitud fué mucho menor, pero la precisión no se afectó grandemente. La baja exactitud fué causada por una compresión del rango de datos en los valores predecidos cuando se compararon con los valores de referencia, y los niveles predecidos de artemisa en la dieta deben ser considerados para representar un intervalo en la escala de medición. La regresión linear o procedimiento PLS (partial least-squares regression) modificada resulto en una mejor calibración que la regresión múltiple (stepwise regression), y la calibración de los grupos de datos con niveles altos, bajos y sin artemisa resultaron en calibraciones casi tan buenas como los grupos de datos con varios niveles intermedios de artemisa. Niveles altos de estadística-H (H statistic) estuvieron relacionados a una baja precisión, pero no afectaron la exactitud de las predicciones. Creemos que el intervalo en la escala de medición que representa la Espectroscopía de Reflectancia en el Infrarrojo Cercano en la predicción de la composición de la dieta contiene suficiente información para responder muchas preguntas en relación a praderas. 
1992, Leite and Stuth 1995), and botanical composition (Walker et al. 1998) when the validation samples are a subset of the calibration population. Currently, NIRS of fecal material is used to predict dietary composition of samples whose relationship to the calibration population is not well known (Snowder et al. 2001, USDANRCS 1999), even though Coleman et al. (1995) warned that extrapolation beyond the conditions represented in the calibration samples is risky.

Because the material being predicted (i.e., the diet) is not available for standard laboratory analysis, the use of NIRS to predict dietary parameters of grazing animals presents unique challenges compared to other agricultural applications of this technique. In other applications of NIRS technology, if samples are spectrally different from the calibration population, or if the predicted value is outside the expected range, the true reference value of the sample can be determined by standard laboratory procedures.

One of the statistics used in NIRS analysis to determine if a sample is from the same spectral population as the samples that the calibration equation was developed from is called H (Shenk 1989). The $\mathrm{H}$ statistics is the distance of the sample from the population centroid (i.e., the population mean in multi-dimensional space). The $\mathrm{H}$ statistics is standardized to have unit variance so it represents the number of standard deviations that a sample is from the multi-dimensional population mean. Shenk (1989) suggested that if the $\mathrm{H}$ of a predicted sample is greater than 3 standard deviates from the average spectrum of the calibration samples, the results should be reported with caution. Whereas the use of $\mathrm{H}$ for typical NIRS agricultural applications was investigated by Shenk (1989) and Shenk and Westerhaus (1991a,1991b), most previous research on using fecal NIRS equations did not examine the relationship of $\mathrm{H}$ to prediction accuracy (Coleman et al. 1989, Lyons and Stuth 1992, Coleman et al. 1995, Leite and Stuth 1995, and Coleman et al. 1999).

The NIRS technique can be calibrated to predict botanical composition of clipped forages composited to create samples of plant mixtures (Coleman et al. 1985, Pitman et al. 1991, Petersen et al. 1987, Moore et al. 1990). The calibration samples in these studies were created by composting mixed samples with known amounts of the different botanical species. Coleman et al. (1990) demonstrated that calibrations based on botanically pure samples were as acceptable as calibrations developed from mixtures. Volesky and Coleman (1996) showed that the addition of botanically pure samples to esophageal extrusa calibration data sets was beneficial. However, pure diets of many of the plant species of interest to the study of dietary habits of ruminants cannot be fed because of problems with toxicosis at high levels of intake. Nonetheless, it may be possible to predict botanical composition of diets with just 2 levels of the component of interest, which would provide a great improvement in the design of calibration trials by reducing the number of samples required for calibration.

Development of calibration equations using stepwise regression techniques (with a limited number of individual wavelengths) has not been compared with multivariate procedures using information from all wavelengths. Multivariate procedures use a data reduction technique such as principal component analysis (PCA), which reduces the original data to sets of scores that have 2 properties 1) the variance of the first set of scores is maximized and successive sets of scores explain successively less of the variation in the original data; and 2) the sets of scores are uncorrelated to each other. This is accomplished by multiplying the original $\log 1 / \mathrm{R}$ data by a weighting coefficient (i.e., eigenvector) and summing these values across all wavelengths to create a score for each sample. This is analogous to the coefficients in a multiple regression equation transforming a set of independent variables to a single dependent variable, i.e., predicted $\mathrm{Y}$ variable. The principle component scores produced can then be used in multiple regression to predict the value of the dependent variable (i.e., botanical composition in the current study). In this study we used modified partial least squares regression, which is similar to PCA regression except that information from the dependent variable is included in the transformation so that the resultant scores have maximum correlation with the dependent variable and the residuals obtained after each factor is calculated are standardized (divided by the mean residual value) before calculating the next factor. Pitman et al. (1991) reported there were no consistent differences between modified partial least squares regression and modified stepwise regression when predicting the botanical composition of tropical grass-legume mixes.
The objective of this study was to determine if NIRS of fecal samples could predict the percentage of mountain big sagebrush (Artemisia tridentata Nutt. ssp. vaseyana (Rydb) Beetle) in sheep diets. Four specific objectives were evaluated: 1 ) stepwise regression was compared to modified partial least squares regression; 2) calibrations based on maximum, minimum, and no sagebrush in the diets were compared to calibrations that included intermediate levels of sagebrush; 3 ) the ability of calibrations based on diets composed of dried sagebrush to predict diets from frozen sagebrush were investigated; and 4) the relationship of $\mathrm{H}$ with the precision and accuracy of predictions was investigated.

\section{Methods $^{1}$}

This research was conducted at the USDA, U.S. Sheep Experiment Station located in Dubois, Ida. $\left(112^{\circ} 10^{\prime} \mathrm{W}\right.$, $\left.44^{\circ} 21^{\prime} \mathrm{N}\right)$. Fecal materials from a feeding trial with sheep fed known levels of sagebrush with several background diets were used to develop NIRS fecal calibration equations. Equations were validated with samples from 2 independent feeding trials with known levels of sagebrush with a single background forage. Because the composition of the base diet did not vary in the validation trials, calibration equations for sagebrush were identical to equations for other components, and samples from these trials could not be used to develop unambiguous calibration equations.

\section{Feeding Trial}

The 1996 feeding trial consisted of feeding varying levels of mountain big sagebrush, early bloom alfalfa hay (Medicago sativa L.) and a grass hay composed of smooth brome (Bromus inermis Leyss.) and timothy (Phleum pratense L.). The sagebrush was collected in late September 1996 and air-dried in the shade (maximum daily temperature 21 to $30^{\circ} \mathrm{C}$ ). After drying, sagebrush branches were flailed against a wire panel over a large tub to remove leaves and small current year's stems.

The flailed sagebrush was chopped using a small flail-type garden shredder;

\footnotetext{
${ }^{\mathrm{I}}$ Protocols for feeding trials were approved by Animal Care and Use Committee of the U.S. Sheep Experiment Station and the University of Idaho \# 8028).
} 
other forages were ground through a hammer mill with a $2.5 \mathrm{~cm}$ screen. Diets were mixed to contain $0,4,8,12,16$, and $24 \%$ sagebrush with a base diet of hays in the following alfalfa/grass proportions: 0:100, 20:80, 40:60, 60:40, 80:20, and 100:0 for a total of 36 different diets. Molasses was added to the diets (5\% DM) during the mixing process to cause feed particles to adhere together and reduce sorting when eaten.

Diets were fed to 36 mature, whitefaced, western range ewes housed in individual pens. One animal was fed each diet. Diets were fed at 0800 and 1600 hours; refusals (orts) were removed at 0800 hours. The trial consisted of a 6-day adaptation period and 4-day collection period. Fecal samples were collected from the floor of the pens at 1600 and 0800 hours and dried in a forced air oven at $60^{\circ} \mathrm{C}$.

\section{Feeding Trial}

The 1998 feeding trial consisted of varying levels of mountain big sagebrush stored either air-dried or frozen before the study (Fraker 1999). Sagebrush for this trial was current season's growth of vegetative stems (no flowering stalks) collected the last week of August 1997. Half of the sagebrush was air-dried (maximum temperature 30 to $33^{\circ} \mathrm{C}$ ) and stored in plastic bags; half was frozen promptly after collection and stored in a freezer. Diets were mixed to contain $0,8,16$, and $24 \%$ of either dry or frozen sagebrush with a base diet of 1:1 alfalfa/grass (grass was a mixture or smooth brome and timothy hay) for a total of 7 different diets. Molasses was added to the diets (5\% DM) during the mixing process to cause feed to adhere together and reduce sorting.

An intake and digestion trial was conducted in January 1998 using 6 to 7 month-old, white-faced crossbred lambs with an average weight of $47 \mathrm{~kg}$. The animals were penned individually and 5 animals were assigned to each of the 7 diets for a total of 35 animals (34 wethers and 1 ewe). Animals were fitted with fecal bags to determine total fecal production. Feed was offered in excess from 0800 to 1100 hours and from 1300 to 1600 hours. Every 30 min, while feed was offered, feed bunks were checked and more feed was added if needed. This procedure limited the potential for sorting and minimized the amount of refusal. The trial consisted of a 5-day adaptation period and a 6-day collection period. Fecal bags were emptied twice daily, and a sub-sample of feces was collected. Afternoon samples were composited with collections made the following morning and dried in a forced air oven at $60^{\circ} \mathrm{C}$.

\section{Wyoming Feeding Trial}

The Wyoming trial used 16 Rambouillet wether lambs ( 28 to $41 \mathrm{~kg}$ body weight) fed diets containing mixtures of hand-harvested current year's growth of mountain big sagebrush leaves and native grass hay (Ngugi et al. 1995). Sagebrush leaves were harvested in September from the western edge of the Medicine Bow Range, Carbon County, Wyo., and stored in sealed plastic bags in a freezer until fed. Four diets in the following proportions of grass hay:sagebrush: 100:0, 90:10, 80:20, and 70:30 were fed. Four animals received each diet. The trial consisted of a 9-day adjustment period followed by a 6-day collection period when all urine and feces were collected. Fecal samples were composited by animal for the 6-day collection period and ground through a 1-mm screen of a Wiley mill. Samples were reground through a cyclone mill before being scanned to collect NIRS reflectance. Details of this trial were presented by Ngugi et al. (1995).

\section{Equation Development}

All fecal samples were ground in a cyclone mill to pass a 1-mm screen, packed into sample cells with a nearinfrared transparent quartz cover glass, and scanned 32 times using a NIR Systems, Inc. (Silver Spring, Md.) model 6500 , scanning reflectance monochromator. Reflected energy $(\log 1 / \mathrm{R})$ was measured, averaged over the 32 scans and recorded at $2-\mathrm{nm}$ intervals from 400 to $2,500 \mathrm{~nm}$.

Calibration equations were developed using stored NIRS spectra from fecal samples as the independent variables and percent sagebrush fed in the diets as the dependent reference data. Scanned samples were daily individual animal feces in the 1996 and 1998 trials, whereas for the Wyoming trial, they were individual animal feces composited across 6-days. Before calibration, each spectrum was transformed with a $(1,8,8)$ derivative. The first number in parenthesis is the order of the derivative, the second number is the gap (number of data points over which the derivative is calculated), and the third number is the smooth (number of data points in a moving average). Scatter correction was done with the standard normal variance and detrend procedure (Barnes et al. 1989).

\section{Data Analyses}

Before further analyses, data from the 1996 and 1998 trials were individually examined to identify and remove outlier samples. To eliminate outliers, separate calibration equations were done for the 1996 and 1998 trials. Samples that had an $\mathrm{H}$ larger than 3 or a residual " $\mathrm{t}$ " statistic greater than 3 were eliminated. This resulted in the elimination of 6 and 10 samples from the 1996 and 1998 data sets, respectively, or approximately $5 \%$ of the samples from each of the data sets.

Calibration equations were evaluated for usefulness based on validation statistics for samples that were not used for calibration. Calibration refers to the development of a regression equation using the reflected energy $(\log 1 / \mathrm{R})$ of the near infrared spectra as independent variables to predict the botanical component (i.e., dependent variable or reference value). Validation refers to the ability of the calibration equation to predict the reference value of samples not part of the data set used in the development of the calibration equation. Validation samples are referred to as 'internal' if they are a subset of a uniform group of samples used to develop a calibration equation and independent if they were from a set of samples from a different trial or treatment. The statistics evaluated included standard error of prediction (SEP), standard error of prediction corrected for bias (SEPc), coefficient of determination $\left(\mathrm{R}^{2}\right)$, slope, and bias.

These statistics indicate the relationship between the predicted percentage sagebrush in the diets and the percentage sagebrush that was fed. The coefficient of determination is the amount of variation in sagebrush fed that is explained by fecal NIRS predictions and is an indicator of the precision of the calibration equation. Slope and bias are estimates of the accuracy of the calibration equation; in general accuracy decreases as the deviation from 1 and 0 , respectively, increases. However, slopes may not always be directly comparable because of the differences in the $Y$ intercept. The SEP and SEPc statistics are estimates of error in units that are related to the unit of measurement; in this study the percentage sagebrush in the diet. The SEP includes error that results from poor 
precision (i.e., lack of fit) and systematic error as a result of slope and bias deviations from 1 and 0 . The SEPc has much of the systematic error (lack of accuracy) removed and is an indicator of precision.

Objective 1: This objective compared stepwise (SW) and modified partial least squares (MPLS) calibrations. Fecal samples from days 1 and 3 of the 1996 trial (96 1\&3) were used to develop calibration equations using either SW, or MPLS regressions and validated with either days 2 and 4 (96 2\&4) from the same trial (i.e., internal validation), or the 1998 Dry samples (i.e., independent validation). The 1998 Dry samples were used for independent validation because they most closely duplicated the procedures used for the feeding trial from which samples for calibration were produced. The best calibration method was determined by comparing validation statistics and then was used for all further analyses.

Objective 2: This objective examined the effect of eliminating diets with intermediate levels of sagebrush on the precision and accuracy of resultant calibration equations. The purpose of this objective was to determine if the efficiency of feeding trials for developing fecal NIRS calibration equations could be improved by reducing the number of levels fed without affecting the precision or accuracy of predictions. The MPLS calibrations were developed for all 1996 samples and compared to calibrations from 3 subsets: HiLo All contained all samples with 0,4 , and 24\% sagebrush; HiLo Mixed contained samples with $60: 40$ or 40:60 proportions of alfalfa and grass as the background and 0, 4 and 24\% sagebrush; HiLo Pure contained samples with $100 \%$ alfalfa or $100 \%$ grass and 0,4 , and $24 \%$ sagebrush. The diets with no sagebrush were included in the calibration data sets because, in practice, treatments with only the base diets require relatively less labor to conduct because the target plant species does not need to be hand-collected. Thus the additional level can be added to the calibration data set at a relatively low cost. The calibrations for this objective were validated using the 1998 Dry samples.

Objectives 3: The purpose of this analysis was to evaluate the ability of calibration equations developed from feeding trials using target forages that were dried to predict diets from feeding trials where the target forage was kept frozen until fed. The latter case more closely represents a normal grazing situation, whereas the use

Table 1. Comparison of stepwise to modified partial least squares regression equations on validation statistics for calibrations developed from the 1996 trial on days 1 and 3.

\begin{tabular}{lcccccc}
\hline \hline Validation data set & $\mathrm{R}^{2}$ & Slope $^{\mathrm{a}}$ & Bias $^{\mathrm{b}}$ & SEP $^{\mathrm{c}}$ & SEP(c) $^{\mathrm{d}}$ & Average H $^{\mathrm{e}}$ \\
\hline 96 2\&4 & & & & & & \\
Stepwise & 0.92 & 1.00 & 0.1 & 2.2 & 2.2 & 1.4 \\
MPLS & 0.96 & 1.01 & 0.4 & 1.6 & 1.6 & 1.5 \\
98 Dry & & & & & & \\
Stepwise & 0.66 & 1.10 & 4.1 & 6.4 & 5.0 & 2.0 \\
MPLS & 0.93 & 1.26 & 3.9 & 4.8 & 2.8 & 2.7 \\
\hline
\end{tabular}

${ }^{\mathrm{a}}$ Slope $=$ slope of the line between reference and predicted values (indicator of accuracy).

${ }^{\mathrm{b}} \mathrm{Bias}=$ systematic error (i.e., mean of differences, and an indicator of accuracy).

${ }^{c} \mathrm{SEP}=$ standard error of prediction (error caused by both lack of precision and lack of accuracy).

${ }^{d} \mathrm{SEP}(\mathrm{c})=$ standard error of prediction corrected for bias (indicator of precision).

${ }^{\mathrm{e}}$ Average $\mathrm{H}=$ standardized Mahalanobis distance (mean spectral distance of validation data set from centroid of calibration data set in multiples of standard deviates).

of dried forages represents a simpler method for conducting trials. Calibrations were developed using all samples from the 1996 trial. Frozen samples from 1998 and Wyoming samples were used for validation and dried samples from 1998 served as a control.

Objective 4: The effect of the value of $\mathrm{H}$ on the precision and accuracy of predictions was evaluated for the 1998 Frozen and Wyoming data sets. The value of $\mathrm{H}$ is the number of standard deviates that a particular sample is from the mean of the population of samples that were used to develop the calibration equation. Thus it represents the spectral similarity between the predicted samples and the calibration samples. The simple correlation between $\mathrm{H}$ and the absolute value of the residual was calculated to determine if the precision of predictions (i.e., difference between actual and predited values) was related to the spectral closeness of the sample to the calibration population. Each data set was divided in half based on the median value of $\mathrm{H}$ in the data set. The predictions were compared between the 2 subsets to determine the effect of $\mathrm{H}$ on accuracy of predictions. If the slope of the line relating the predicted and actual levels of sagebrush in the diets was the same for both of the subsets of data, it would indicate that accuracy was not affected by the spectral distance (i.e., $\mathrm{H}$ ) between the sample and the calibration population.

\section{Results and Discussion}

Objective 1: Comparison of stepwise (SW) and modified partial least squares (MPLS) calibrations for days 1 and 3 of the 1996 trial showed that calibration using MPLS improved predictions for both the internal and independent valida- tion data sets (Table 1; Fig. 1). Predictions for the internal validation set $(96,2 \& 4)$ showed that MPLS compared to SW slightly increased the precision of predictions as indicated by the higher R2 and lower SEP(c), but not the accuracy of predictions (i.e., bias and slope). The value of MPLS compared to SW calibrations for improving precision were more apparent for the independent validation of the 1998 Dry samples. In this comparison $\mathrm{R}^{2}$ and SEP(c) showed much improvement in MPLS compared to SW, the similar bias for the 2 predictions showed that accuracy was about equal. The improved precision of the MPLS calibration compared to the SW calibration indicates that the wavelengths selected by the stepwise procedure for the 1996 calibration data set did not include all of the relevant wavelengths for the independent 1998 Dry validation data set. The average $\mathrm{H}$ value was higher for the MPLS predictions of the 1998 Dry samples compared to the SW prediction of these samples. The higher $\mathrm{H}$ statistic is a result of the use of all wavelengths in the MPLS equation compared to only 5 wavelengths in the SW equation. This apparent increase in spectral distance between independent predictions and the mean calibration spectra, and the assumption that it reduces the robustness of the resultant equations, caused most previous fecal NIRS calibrations to use SW equations. Because of the improved precision of predictions using the MPLS equation, this calibration procedure was used for subsequent analysis.

Objective 2: The effect of calibrations based on the 1996 trial after removing the samples with intermediate levels of sagebrush (i.e., 8,12 , and $16 \%$ ) on precision and accuracy for predictions of the 1998 Dry samples, is shown in Table 2 and Figure 2. Reducing the number of samples reduced the accuracy of predictions, but 


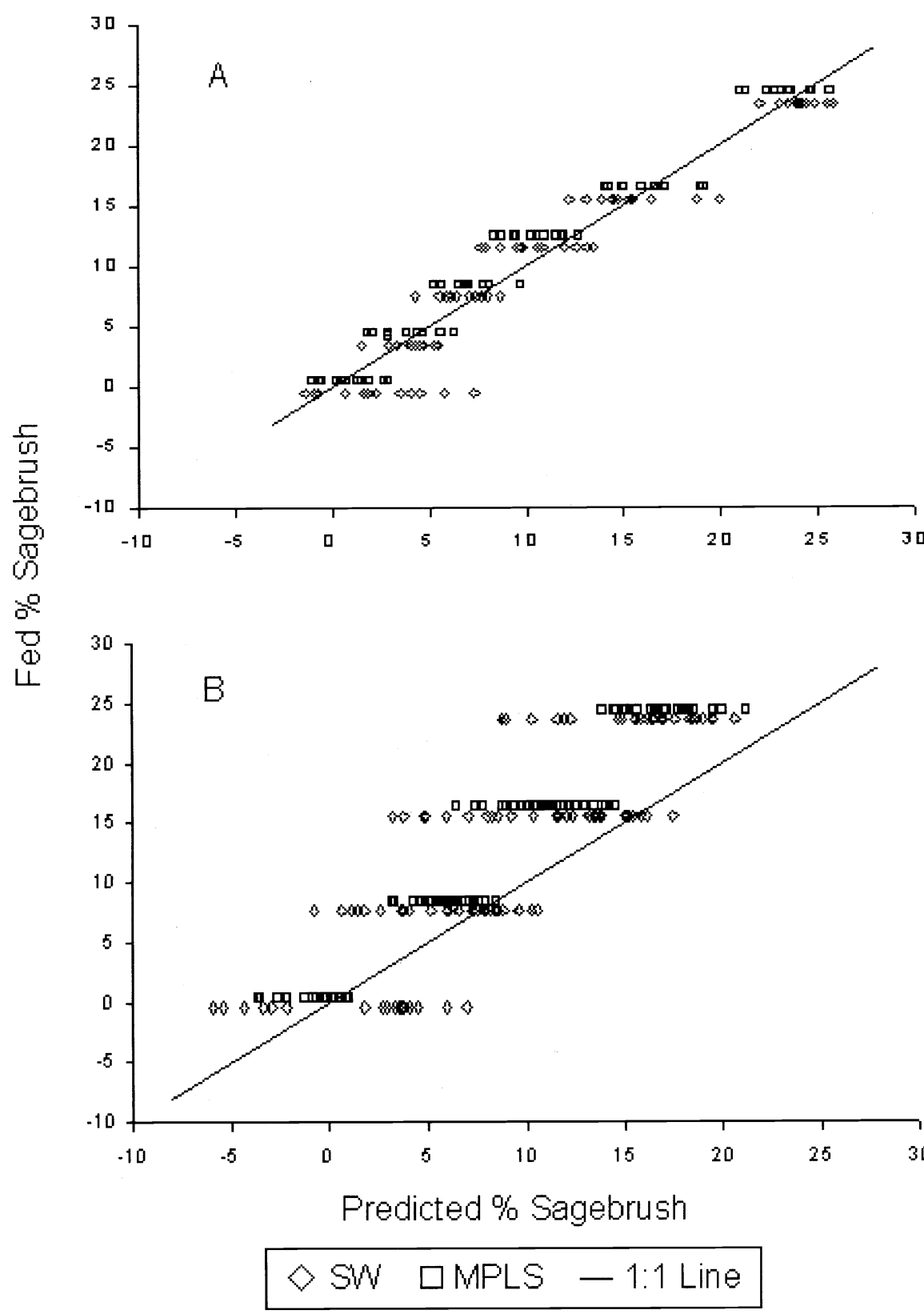

Fig. 1. Comparison of stepwise regression (SW) and modified partial least squares regression (MPLS) predictions of percent sagebrush fed using 1996 feeding trial days 1 and 3 for calibration and either internal validation with 1996 days 2 and 4 for validation (A) or independent validation using 1998 Dry samples for validation (B).

this reduction was less than the proportional decrease in number of samples. For instance the HiLo ALL subset represented a $50 \%$ reduction in the number of samples but only a $3 \%$ reduction in the $\mathrm{R}^{2}$ between actual and predicted diets, a slope with a $4 \%$ greater deviation from unity, a $27 \%$ increase in the SEP, and a $16 \%$ increase in SEP(c).

Further reducing the calibration data sets to 23 samples by using only samples from diets with mixed alfalfa and grass
(HiLo Mixed) background or $100 \%$ alfalfa or $100 \%$ grass (HiLo Pure) as a background further reduced the precision and accuracy of predictions. Validation statistics from calibrations based on HiLo Mixed samples showed that this subset resulted in a much higher bias and a slope with a greater deviation from unity. The reduced performance of HiLo Mixed calibrations presumably was caused by a lack of unique spectral information between the 60:40 and 40:60 alfalfa:grass background mixtures compared to the $100 \%$ alfalfa or $100 \%$ grass background mixtures.

As the number of samples in the calibration data set was reduced, the average $\mathrm{H}$ of the validation data decreased, even though the validation data set was the same for the 4 different calibration data sets. This would normally be interpreted to mean that the validation data were more spectrally similar to the calibration data. However, in this instance it indicates that as the number of samples in the calibration data set decreased the variance of the multidimensional centroid increased and because $\mathrm{H}$ is standardized to have unit variance the distance of the predicted population from the calibration population is smaller in terms of multiples of the unit variance.

Comparison of the MPLS validation statistics for 1998 Dry samples between Tables 1 and 2 also demonstrates the effect of size of calibration data set on the average value of $H$. In this instance the slope and $R^{2}$ are essentially the same for calibrations based on days 1 and 3 of the 1996 samples (Table 1) or all days (Table 2 ), but the average $\mathrm{H}$ statistic increased from 2.7 to 3.8 when all of the samples were used in the calibration data set.

This analysis indicates that increased efficiency of experimental design can be obtained by reducing the number of intermediate levels and that there is an advantage of using spectrally distinct backgrounds, i.e., pure rather than mixed background diets.

Objective 3: The use of calibrations based on dried samples to predict diets of animals eating an independent source of frozen forage is shown in Table 3 and Figure 3. Compared to the 1998 Dry samples, the validation statistics for the 1998 Frozen samples showed that the slope for the frozen samples (1.43) was greater than that for the dried samples (1.27), resulting in a larger bias and consequently a larger SEP. The SEP(c) was increased only slightly for the frozen samples, and the $\mathrm{R}^{2}$ was similar for the dried (0.94) and frozen (0.93) predictions. These statistics, in conjunction with the increased deviation from unity of the slope, indicate that using an equation based upon dried forages from the independent 96 trial to predict percentage 98 frozen sagebrush in the diet, decreased the accuracy of predictions with little effect on the precision.

Validation using the Wyoming samples was much worse than the 1998 Frozen samples, but was similar to the 1998 
Table 2. Effect of reducing the number of intermediate treatment levels in the Calibration data set on validation statistics for 1998 Dry samples.

\begin{tabular}{lrccrrcc}
\hline \hline Calibration data set & $\mathrm{n}^{\mathrm{a}}$ & $\mathrm{R}^{2}$ & Slope $^{\mathrm{b}}$ & \multicolumn{1}{c}{ Bias $^{\mathrm{c}}$} & SEP $^{\mathrm{d}}$ & SEP(c) & Average $^{\mathrm{f}}$ \\
\hline 96 All $^{\mathrm{g}}$ & 137 & 0.94 & 1.27 & 4.8 & 5.6 & 2.7 & $3.8^{*}$ \\
HiLo All $^{\mathrm{h}}$ & 69 & 0.91 & 1.33 & 6.9 & 7.6 & 3.2 & 2.2 \\
HiLo Mixed $^{\mathrm{i}}$ & 23 & 0.78 & 1.61 & 16.4 & 17.2 & 4.9 & 2.3 \\
HiLo Pure $^{\mathrm{j}}$ & 23 & 0.82 & 1.38 & 8.6 & 9.5 & 4.2 & 1.3 \\
\hline
\end{tabular}

${ }^{a}$ Number of samples in calibration data set.

${ }^{\mathrm{b}} \mathrm{Slope}=$ slope of the line between reference and predicted values (indicator of accuracy).

${ }^{c}$ Bias = systematic error (i.e., mean of differences, and an indicator of accuracy).

${ }^{\mathrm{d}} \mathrm{SEP}=$ standard error of prediction (error caused by both lack of precision and lack of accuracy).

${ }^{\mathrm{e}} \mathrm{SEP}(\mathrm{c})=$ standard error of prediction corrected for bias (indicator of precision).

${ }^{\mathrm{f}}$ Average $\mathrm{H}=$ standardized Mahalanobis distance (mean spectral distance of validation data set from centroid of calibration data set in multiples of standard deviates).

$\mathrm{g}_{96}$ All $=$ all samples.

${ }^{\mathrm{h}}$ HiLo All $=$ all samples with 0,4 , or $24 \%$ sagebrush.

${ }^{\mathrm{i}}$ HiLo Mixed = samples with background matrix of 40:60 or 60:40 alfalfa and grass hay with 0,4 , or $24 \%$ sagebrush.

${ }^{\mathrm{H}}$ HiLo Pure $=$ samples with background matrix of $100 \%$ alfalfa or $100 \%$ grass hay with 0,4 , or $24 \%$ sagebrush.

*Exceeded value recommended by Shenk et al. (1989).
Frozen in that most of the error was a result of reduced accuracy. The low accuracy was caused primarily by the high slope (2.63), which indicates that the range of the predicted values was about one-third the range of the actual values.

The compressed range of data in these predicted data sets indicates that when the predicted samples are from a different population than the calibration samples, the ratio scale of measurement for the reference value of the samples may be reduced to an interval scale for the predicted values. Measurement scale refers to the different properties (i.e., relationships and operations) of the numbers that can be applied to the measurements. The 4 levels of measurements in order of increasing amount of information that can be determined from them are 1) nominal, 2) ordinal, 3) interval, and 4) ratio. Nominal measurements name the attribute; ordinal interval measurements the distance between attributes has meaning; and ratio measurements have an absolute zero and a meaningful ratio can be constructed. The effect of different scales of measurements on the information that can be extracted from measured attributes can be demonstrated using the reference values of sagebrush fed, which are ratio scale measurements, and the fecal NIRS predicted values, which are interval scale measurements. The mean predicted values for the data were $0.6,6.3$ and $10.9 \%$, respectively. For the reference ratio data it is appropriate to state that the difference between 8 and $24 \%$ is twice as large as the difference between 8 and $16 \%$. It is also appropriate to state that $16 \%$ is 2 times larger and $24 \%$ is 3 times larger than $8 \%$. At the measurements can be rank ordered; for 8,16 and $24 \%$ diets in the 1998 Frozen interval level of measurement for the fecal NIRS predicted values, an increase from 0.6 to $10.9 \%$ is about twice as much as an increase from 6.3 to $10.9 \%$, but it is not appropriate to state that $6.3 \%$ is about 10 times larger than $0.6 \%$. In practice this means that fecal NIRS predictions could be used to estimate the difference in botanical composition of the diets of dif- ferent treatment groups or individuals within a group of animals. But it could not be used to determine how much of a plant species of interest should be fed to increase their level of consumption to a desired level.

Objective 4: For typical agricultural applications, the size of $\mathrm{H}$ (i.e., the standardized spectral distance of the predicted sample from the calibration data spectral mean) normally is used to determine if a sample is from the same spectral population as the samples used to develop calibration equations. This analysis investigates the relationship between $\mathrm{H}$ and the precision and accuracy of predictions when calibration equations from the 1996 trial were used to predict the 1998 Frozen or Wyoming diets. The value of $\mathrm{H}$ was positively correlated to the absolute value of the residual (Fig. 4), which indicates that prediction error increased as $\mathrm{H}$ increased. However, when the data sets were split into two groups based on the median value of $\mathrm{H}$, the slope $(\mathrm{P}>0.30)$ and intercept $(\mathrm{P}>0.30)$ of the predictions for the 2 groups were not affected by the

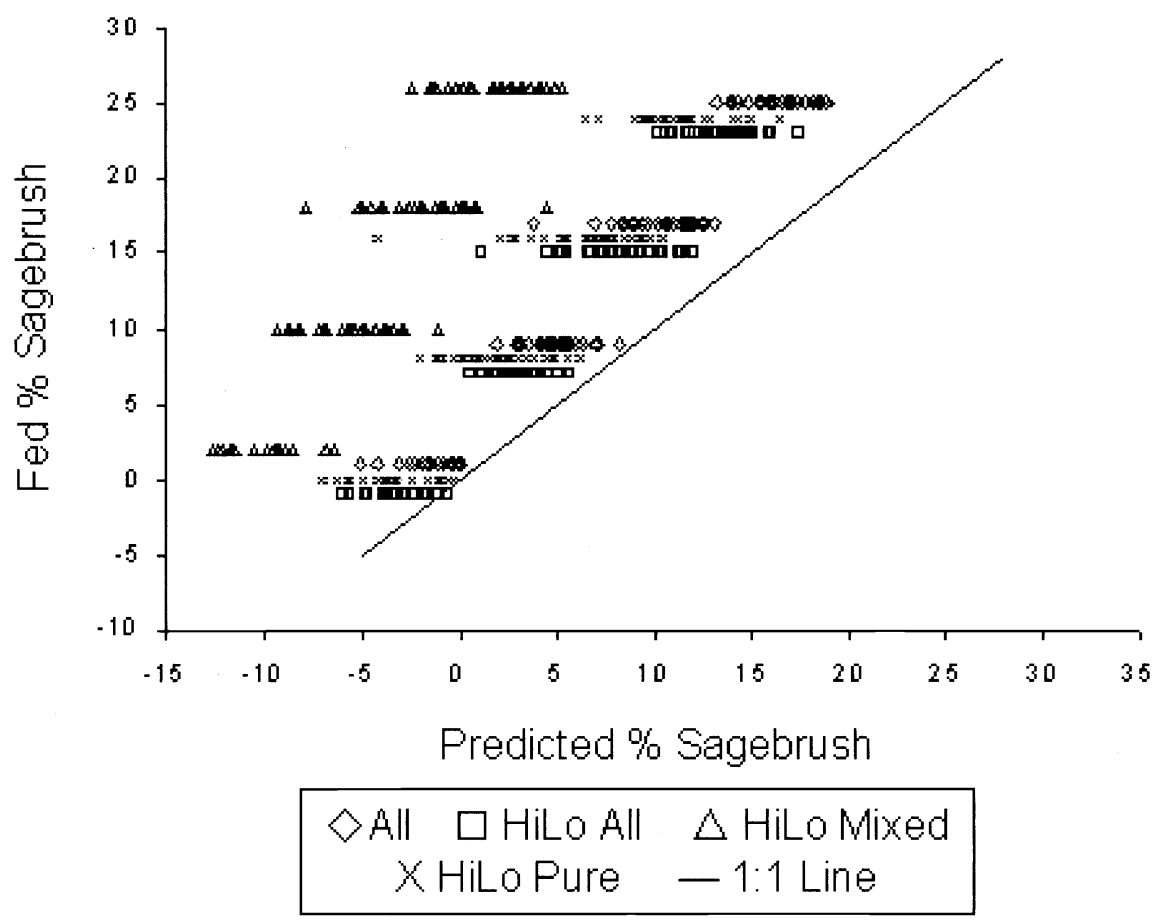

Fig. 2. A comparison of modified partial least squares calibrations using reduced subsets of calibration samples from the $\mathbf{1 9 9 6}$ trial was used to predict samples from animals fed dry sagebrush in the 1998 trial. (All = all samples; HiLo $=\mathbf{2 4}, 4$, and $0 \%$ sagebrush with all backgrounds; Mixed $=24,4$, and $0 \%$ sagebrush with 60:40 and 40:60 alfalfa:grass backgrounds; and Pure $=24,4$, and $0 \%$ sagebrush with $100 \%$ alfalfa or $100 \%$ grass backgrounds). 
Table 3. Validation statistics for predicting fresh samples using calibration from 1996 samples with 1998 Dry samples included for comparison.

\begin{tabular}{llllllr}
\hline \hline Validation data set & $\mathrm{R}^{2}$ & Slope $^{\mathrm{a}}$ & Bias $^{\mathrm{b}}$ & SEP $^{\mathrm{c}}$ & SEP $(\mathrm{c})^{\mathrm{d}}$ & Average H $^{\mathrm{e}}$ \\
\hline 1998 Dry & 0.94 & 1.27 & 4.8 & 5.6 & 2.7 & $3.8 *$ \\
1998 Frozen & 0.93 & 1.43 & 6.8 & 7.5 & 3.1 & $4.1 *$ \\
Wyoming & 0.9 & 2.63 & 14.2 & 16 & 7.7 & $12.8 *$ \\
\hline
\end{tabular}

${ }^{\mathrm{a}}$ Slope $=$ slope of the line between reference and predicted values (indicator of accuracy).

${ }^{\mathrm{b}} \mathrm{Bias}=$ systematic error (i.e., mean of differences, and an indicator of accuracy).

${ }^{\mathrm{c}} \mathrm{SEP}=$ standard error of prediction (error caused by both lack of precision and lack of accuracy).

${ }^{d} \mathrm{SEP}(\mathrm{c})=$ standard error of prediction corrected for bias (indicator of precision).

${ }^{\mathrm{e}}$ Average $\mathrm{H}=$ standardized Mahalanobis distance (mean spectral distance of validation data set from centroid of calibration data set in multiples of standard deviates).

Exceeded value recommended by Shenk et al. (1989).

size of H (Fig. 5). Walker et al. (1998) reported that when NIRS fecal predictions for percent leafy spurge (Euphorbia esula L.) in the diet were divided into groups based on the size of $\mathrm{H}$, validation statistics were similar between the groups.

The positive relationship between $\mathrm{H}$ and magnitude of the residual and the lack of effect of $\mathrm{H}$ on the relationship between actual and predicted percent sagebrush in the diets show that for these data, the value of $\mathrm{H}$ is positively related to precision but not to accuracy. This interpretation of the relationship of $\mathrm{H}$ to the precision and accuracy of predictions is also supported by comparison of the average $\mathrm{H}$ for the 1998 Frozen and Wyoming samples to their validation statistics. The Wyoming data set had a much higher average H (12.8) compared to the 1998
Frozen samples (4.1) and a much lower accuracy (i.e., slope $=2.63$ vs. 1.43 ), but good precision as shown by the high $\mathrm{R}^{2}$ (0.90 vs. 0.93 ; Table 3$)$. Finally, in both trials the treatments with the highest levels of sagebrush had the highest $\mathrm{H}$ values, which may have implications on the source of this spectral variation.

The results of this study show that when predicted samples are from the same population as the calibration samples, such as the internal validation of the 1996 trial (Table 1), NIRS of feces can accurately predict botanical composition of diets. However, when predicted samples are from a different population, accuracy is low and the predicted values should be considered to represent an interval scale of measurement. Of interest is that the precision of the predictions, as indicated by

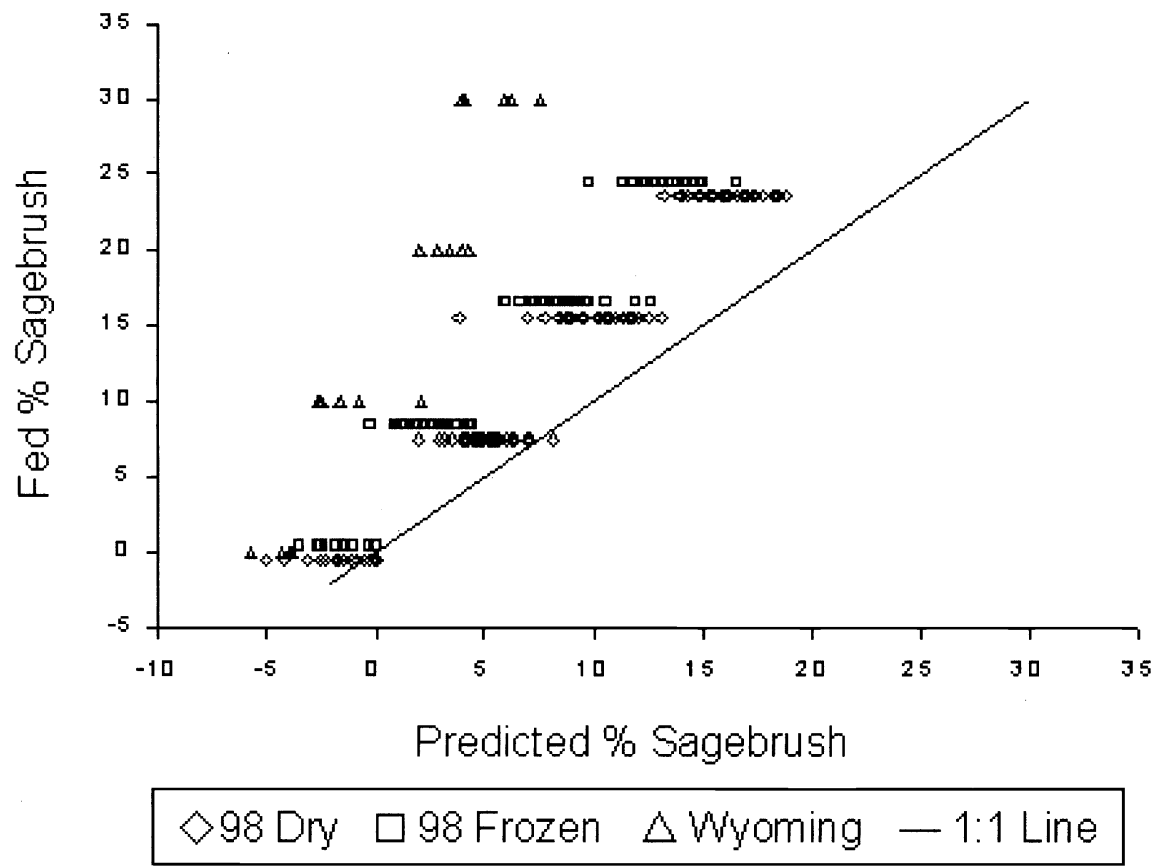

Fig. 3. Prediction of diets from frozen sagebrush using calibration equations based on diets from dried sagebrush; predictions of dry samples are included for comparison. coefficients of determination between actual and predicted values, consistently accounted for $90 \%$ or more of the variation. The consistently high precision but low accuracy may indicate that the wavelengths that best predicted the calibration set were not the optimal set for the validation data sets. However, the wavelengths from the calibration data sets apparently covaried closely with the appropriate wavelengths for the independent validation set.

The suspected shift in optimal wavelengths between the calibration and validation data sets could be caused by the fact that the 1996 calibration diets used one source of sagebrush for all diets, which caused low spectral variation in the feces and may be responsible for the poor accuracy of prediction of independent samples. Use of a single source of sagebrush means that all diets regardless of the proportion of sagebrush in them had the same spectral information relative to sagebrush. Had more sources, e.g., locations, season and years of sagebrush been used the resultant equation would have been more global.

However, animal variation between trials also may have been an important contribution to the lack of accuracy. Mature ewes were used for the 1996 calibration trial, whereas approximately 6 month old whether lambs were used for all of the independent validations.

Age, sex, or physiological status of the animal could affect fecal composition via the effect these factors have on intake and digestibility. Furthermore, the amount of sagebrush in the diet affects both intake and digestibility (Ngugi et al. 1995), and these effects are greater for fresh compared to dried sagebrush (Fraker 1999). Typically $60 \%$ or more of ruminant feces is composed of metabolic products including bacteria and endogenous waste (Van Soest 1982). The remainder of the feces composed of residual forage matter would consist of undigested plant cell walls (i.e., neutral detergent fiber).

Comparison of the slopes of the independent validation sets shows that as the effect of treatments on intake and digestibility increased, the accuracy (but not precision) of the predictions decreased. In the 1998 trial, frozen diets caused a small decrease of forage intake (Fraker 1999), which was associated with an increase in average $\mathrm{H}$ and greater deviation from unity of the slope (i.e, 1.27 and 1.43 for the dry and frozen diets, respectively). 


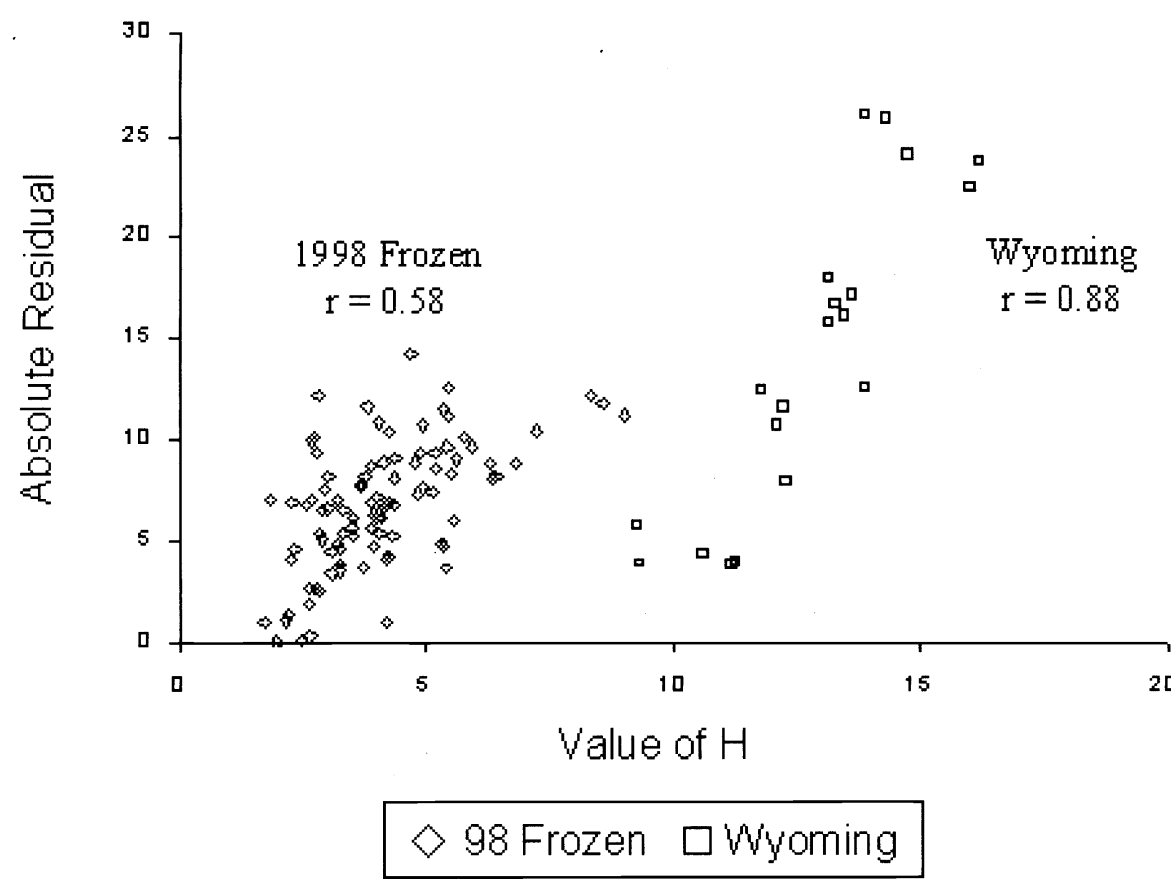

Fig. 4. Relationship between the $H$ value of samples and the absolute value of the residual for independent validation samples and modified partial least squares regression using all 1996 samples.

Ngugi et al. (1995) reported a much greater effect of percent sagebrush in the diet on intake and digestibility for the Wyoming trial than was reported for the 1998 trial. Intake declined from $38 \mathrm{~g} / \mathrm{kg}$

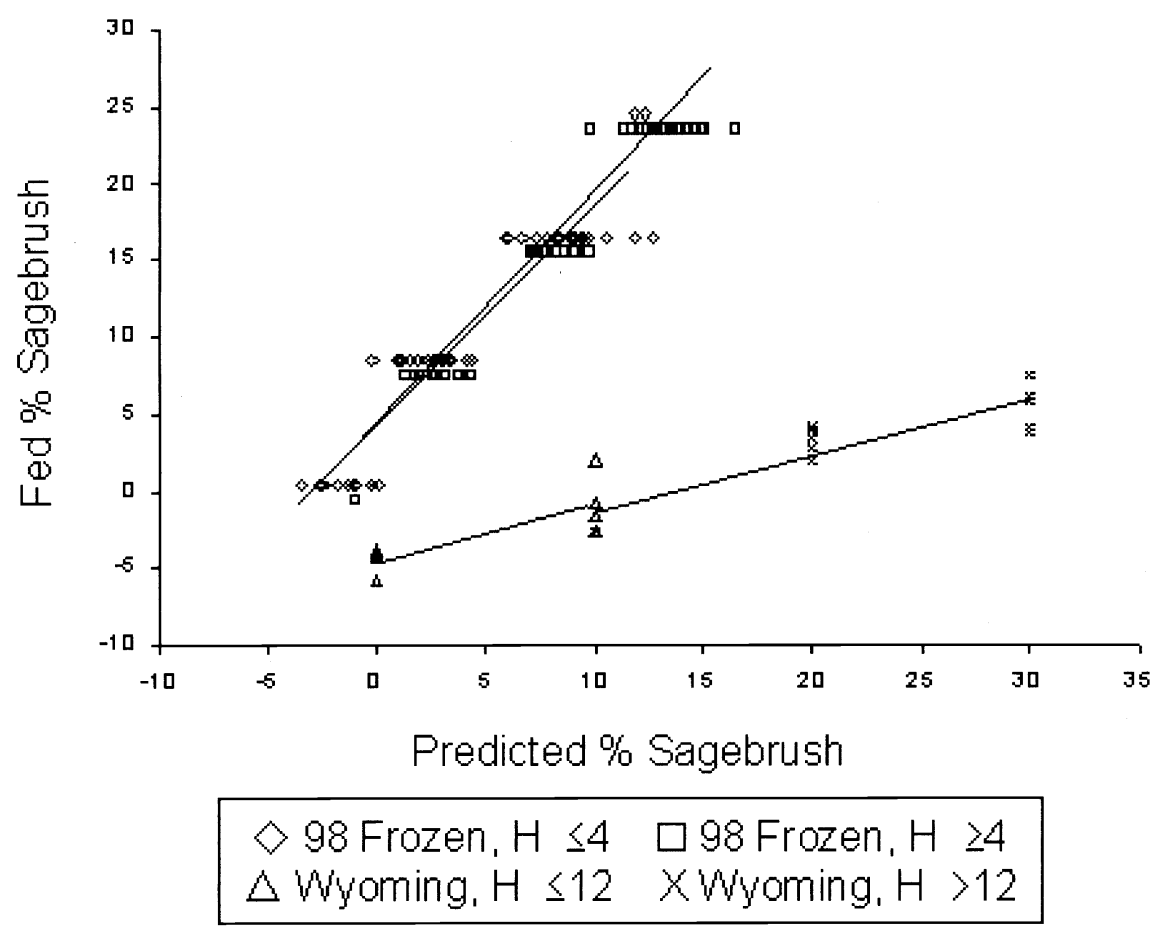

Fig. 5. Effect of size of $H$ on the validation accuracy. intake and digestibility was associated with a much larger average $H$ and lower slope than the 1998 predictions. This may indicate that when fecal NIRS is used to predict the percent of a chemically defended plant in the diet, the spectra on which the calibrations are based may result from the effect of secondary plant metabolites on the digestive process rather than the plant residues in the feces. If this is the case, the loss of accuracy for independent validations noted in this study may be somewhat lessened when fecal NIRS is used to predict the diets of grazing herbivores because animals normally will limit their intake of chemically defended plants below a level that restricts the rate of nutrient capture (Provenza 1995.)

\section{Conclusions}

Relative to the design of future trials for developing fecal NIRS calibration equations, several recommendations can be made from these results. Variation in the source of a target plant species, the background forages, and the animals used for the trial should be maximized to the extent possible. The composition of diets should consist of the 'high' level of the target plant that is slightly above the amount expected to be selected by free grazing herbivores, the 'low' level of about $5 \%$ of the target plant, and a diet that consists of only the background forage. Furthermore, we recommend the use of MPLS calibrations to increase the spectral information considered in the calibration equation compared to the limited number of wavelengths that are used in SW calibrations.

When feeding trials are conducted to develop fecal NIRS calibration equations, the samples used for calibration rarely can be considered to be from the same population as the predicted samples. Even if the target plant species is well represented in the diets, other botanical components normally will not be, and the potential associative effects on digestion indicate that assumptions about the populations being the same would be tenuous.

Furthermore, the $\mathrm{H}$ statistic may not always indicate if a sample is from the same population as the calibration set. Therefore, until evidence to the contrary is available, predictions of dietary botanical composition using fecal NIRS should be considered to represent an interval scale of measurement. This scale of measurement 
is adequate for most problems of interest on rangelands such as comparing treatment effects on diet preference or measuring the phenotypic variation in preference for a target plant in a population of animals, but would not be sufficient if it is necessary to know the actual composition of the diet.

The reduced information in the interval scale of measurement compared to a ratio scale of measurement will be more than offset by the ability to greatly increase sample size by using fecal NIRS compared to other methods for determining botanical composition of diets. For instance, Harniss et al. (1975) reported that for sheep grazing sagebrush-bunchgrass rangelands, 150 fistula diet determinations would be necessary to estimate the percent of plant species that comprise $20 \%$ of the diet to within $\pm 10 \%$ of the mean with a $95 \%$ probability. Such sampling intensity exceeds the practical capacity of any other available method for determining botanical composition of diets except fecal NIRS.

\section{Literature Cited}

Barnes, R.J., M.S. Dhanoa, and S. J. Lister. 1989. Standard normal variate transformation and detrending of near-infrared diffuse reflectance spectra. Appl. Spectroscopy. 43:772-777.

Coleman, S.W., R.E. Barton, II, and R.D. Meyer. 1985. The use of near-infrared reflectance spectroscopy to predict species composition of forage mixtures. Crop Sci. 25:834-837.

Coleman, S.W., S. Christiansen, and J.S. Shenk. 1990. Prediction of botanical composition using NIRS calibrations developed from botanically pure samples. Crop Sci. 30:202-207.

Coleman, S.W., H. Lippke, and M. Gill. 1999. Estimating the nutritive potential of forages. p. 647-695. In: H.G. Jung and G.C. Fahey, Jr. (eds.) Proc. $V^{\text {th }}$ Int. Symp. on the Nutrition of Herbivores. San Antonio, Tex.

Coleman, S.W., J.W. Stuth, and J.W. Holloway. 1989. Vol. 2 p. 881-882. In: Monitoring the nutrition of grazing cattle with near-infrared analysis of feces. Proc. XVI Int.. Grassld. Congr. Nice, France.

Coleman, S.W., J.W. Stuth, and J.W. Holloway. 1995. Prediction of intake by near-infrared spectroscopic analysis of fecal samples. p. 145-155. In: F.N. Owens, D. Gill, K. Lusby, and T. McCollum (Ed.) Symp: Intake in Feedlot Cattle. Oklahoma Exp. Sta. P-942.

Fraker, M.J. 1999. Examination of digestive and behavioral mechanisms to explain individual variation in sagebrush consumption by sheep. M.S. Thesis, Univ. Idaho, Moscow, Ida.

Harniss, R.O., D.A. Price, and D.C. Tomlin. 1975. Number of fistula samples needed for determination of sheep diet on sagebrushgrass range. J. Range. Mange. 28:417-419.

Leite, E.R. and J.W. Stuth. 1995. Fecal NIRS equations to assess diet quality of free-ranging goats. Small Ruminant Res. 15:223-230.

Lyons, R.K. and J.W. Stuth. 1992. Fecal NIRS equations for predicting diet quality of free-ranging cattle. J. Range Manage. 45:238-244.

Moore, K.J., C.A. Roberts, and J.O. Fritz. 1990. Indirect estimation of botanical composition of alfalfa-smooth bromegrass mixtures. Agron. J. 82:287-290.

Ngugi, R.K., F.C. Hinds, and J. Powell. 1995. Mountain big sagebrush browse decreases dry matter intake, digestibility, and nutritive quality of sheep diets. J. Range Manage. 48:487-492.

Petersen, J.C., F.E. Barton, II, W.R. Windham, and C.S. Hoveland. 1987. Botanical composition definition of tall fescue-white clover mixtures by near infrared reflectance spectroscopy. Crop Sci. 27:1077-1080.

Pitman, W.D., C.K. Piacitelli, G.E. Aiken, and F.E. Barton II. 1991. Botanical composition of tropical grass-legume pastures estimated with near-infrared reflectance spectroscopy. Agron. J. 83:103-107.

Provenza. F.D. 1995. Postingestive feedback as an elementary determinant of food preference and intake in ruminants. J. Range Manage. 48:2-17.

Shenk, J.S. 1989. Monitoring analysis results. p. 27-28. In: G.C. Maren, J.S. Shenk, and F.E. Barton II (eds.). Near Infrared Reflectance Spectroscopy (NIRS): Analysis of Forage Quality. USDA Agr. Handb. No. 643.

Shenk, J.S. and M.O. Westerhaus. 1991a. Population definition, sample selection, and calibration procedures for near infrared reflectance spectroscopy. Crop Sci. 31:469-474.

Shenk, J.S. and M.O. Westerhaus. 1991b. Population structuring of near infrared spectra and modified partial least squares regression. Crop Sci. 31:1548-1555.

Shenk, J.S., M.O. Westerhaus, and S.M. Abrams. 1989. Supplement 2. Protocol for NIRS calibration: Monitoring analysis results and recalibration. p. 104-110. In: G.C. Maren, J.S. Shenk, and F.E. Barton II (eds.). Near Infrared Reflectance Spectroscopy (NIRS): Analysis of Forage Quality. USDA Agr. Handb. No. 643.

Snowder, G.D., J.W. Walker, K.L. Launchbaugh, and L.D. Van Vleck. 2001. Genetic and phenotypic parameters for dietary selection of mountain big sagebrush (Artemisia tridentata Nutt. ssp. vaseyana [Rydb] Beetle) in Rambouillet sheep. J. Anim. Sci. 79:486-492.

USDA-NRCS, Grazing Lands Technol. Inst. 1999. Technical Support for the NIRS/NUTBAL Nutritional Management System.
Van Soest, P.J. 1982. The nutritional ecology of the ruminant. O \& B Books, Corvallis, Ore. 374 pp.

Volesky, J.D. and S.W. Coleman. 1996. Estimation of botanical composition of esophageal extrusa samples using near infrared reflectance spectroscopy. J. Range Manage. 49:163-166.

Walker, J.W., D.H. Clark, and S.D. McCoy. 1998. Fecal NIRS for predicting percent leafy spurge in diets. J. Range Manage. 51:450-455. 


\title{
Short-term monitoring of rangeland forage conditions with AVHRR imagery
}

\author{
DAVID P. THOMA, DEREK W. BAILEY, DANIEL S. LONG, GERALD A. NIELSEN, MARI P. HENRY, MEAGAN \\ C. BRENEMAN, AND CLIFFORD MONTAGNE
}

Authors are Research Assistant, Department of Soil, Water and Climate, University of Minnesota, St Paul, Minn.; assistant professors (Bailey and Long), Northern Agricultural Research Center, Montana State University, Havre, Mont.; professors (Nielsen and Montagne) and research assistants (Henry and Breneman), Department of Land Resources and Environmental Sciences, Montana State University, Bozeman, Mont.

Abstract

A study was conducted to determine the potential of using Advanced Very High Resolution Radiometer (AVHRR) imagery to monitor short-term changes in rangeland forage conditions on a regional scale. Forage biomass and nitrogen concentration were estimated at 6 study sites throughout a typical grazing season (April to October). Study sites were located in northern and southern Montana in areas classified as foothills grassland and shortgrass prairie. Normalized Difference Vegetation Index (NDVI) values from AVHRR imagery (1 km pixels) were used to predict live biomass, dead standing biomass, total biomass, nitrogen $(\mathrm{N})$ concentration and standing $\mathbf{N}$. Values of the NDVI were correlated $(r>0.4, P<0.01)$ to live, dead, and total biomass estimates and standing $N$, but were not correlated to $N$ concentration $(r=0.04, P=0.8)$. Relationships between NDVI and vegetative attributes were similar $(P>0.05)$ for all 6 study sites, which indicates that NDVI could be used to predict forage abundance at multiple locations and at variable dates. Using simple linear regression, NDVI accounted for $63 \%$ of the variation in live and total biomass, $18 \%$ of the variation in dead biomass, $66 \%$ of the variation in standing $N$, but $<1 \%$ of the variation in $N$ concentration. The NDVI obtained from AVHRR imagery was a good predictor of forage abundance as measured by live, dead and total biomass as well as standing $\mathrm{N}$, but it was not related to forage quality as measured by $\mathrm{N}$ or crude protein concentration. On a regional basis, land managers could use AVHRR-NDVI values to identify areas with high or low levels of forage abundance that may result from factors such as drought, variable precipitation patterns, or uneven grazing.

Key Words: NDVI, biomass, nitrogen, regional

Forage quantity and quality are major determinants of carrying capacity and performance of grazing animals (Valentine 1990). Ground-based methods are not practical for assessing forage quality and quantity over extensive geographic areas. Remote

Research was funded by the Upper Midwest Aerospace Consortium, Montana Space Grant, Montana State University Mountain Research Center, Montana State University Department of Land Resources and Environmental Sciences and the Montana Agricultural Experiment Station. This manuscript has been assigned Journal Series No. 2000-80, Montana Agricultural Experiment Station, Montana State University, Bozeman.

Manuscript accepted 20 Oct. 01.

\section{Resumen}

Se condujo un estudio para determinar el potencial de utilizar las imágenes de Radiometría Avanzada de Muy Alta Resolución (RAMAR) para monitorear los cambios a corto plazo en las condiciones de forraje del pastizal a escala regional. La biomasa de forraje y las concentraciones de nitrógeno fueron estimadas en 6 sitios de estudio a lo largo de una estación típica de apacentamiento. (Abril a Octubre). Los sitios de estudio estuvieron localizados en el norte y sur de Montana, en áreas clasificadas como pastizales de pie de montaña y pastizales cortos. Los valores del Indice de Diferencias Normalizadas de Vegetación (IDNV) obtenidos a partir de imágenes de RAMAR (pixeles de 1 km) se usaron para predecir la biomasa viva, la biomasa muerta en pie, la biomasa total la concentración de nitrógeno $(\mathrm{N})$ y el $\mathrm{N}$ en pie. Los valores de IDNV se correlacionaron $(\mathrm{r}>0.4, \mathrm{P}<$ 0.01) con las estimaciones de biomasa viva, muerta $y$ total y el $\mathrm{N}$ en pie, pero se correlacionaron con la concentración de $\mathbf{N}(r=$ $0.04, P=0.8$ ). Las relaciones entre IDNV y los atributos vegetativos fueron similares $(P>0.05)$ para los 6 sitios de estudio, lo cual indica que los IDNV pudieran ser usados para predecir la abundancia de forraje en múltiples localidades y en fechas variables. Con regresión lineal simple, el IDNV explicó el 63\% de la variación de la biomasa viva y total, el $18 \%$ de la variación de la biomasa muerta, el $66 \%$ de la variación del $\mathrm{N}$ en pie, pero explicó menos del $1 \%$ de la variación en la concentración de $\mathbf{N}$. EI IDNV obtenido a partir de imágenes de RAMAR fue bueno para predecir la abundancia de forraje medido como la biomasa viva, muerta y total, así como por el $\mathbf{N}$ en pie, pero no estuvo relacionado a la calidad del forraje medida como la concentración de $\mathbf{N}$ o proteína cruda. En base regional, los manejadores de tierras pudieran usar los valores de RAMAR-IDNV para identificar áreas con niveles altos o bajos de abundancia de forraje que pueden resultar de factores tales como sequía, patrones variables de precipitación y apacentamiento desigual.

sensing research has demonstrated, however, that quantity of green vegetation may be estimated using vegetation indices derived from multispectral, aerospace imagery (Tueller 1989 , Wessman et al. 1995). Vegetation indices, which contrast the high chlorophyll absorption region in the red vs. the high reflectivity in the near infrared, are assumed to indicate plant photosynthetic activity and aboveground primary production (Tucker 1979, Wiegand and Richardson 1990). Frequently, red and infrared image bands are used to compute a Normalized 
Difference Vegetation Index (NDVI), defined as the ratio of the difference between near-infrared and red wavelengths to the sum of the 2 (Colwell 1974, Tucker et al. 1983, Justice and Hiernaux 1986).

One of the most commonly encountered NDVI image products is that provided by the NOAA Advanced Very High Resolution Radiometer (AVHRR) (Gutman 1991). The NDVI has been widely investigated for use in predicting the amount of vegetative biomass in rangeland. For example, Merrill et al. (1993) derived a vegetation index from Landsat multispectral scanner data for use as an auxiliary variable for a linear regression model to predict green herbaceous phytomass on rangeland in Yellowstone National Park. Tucker and Vanparet (1985) found a linear relationship between AVHRR-NDVI and end of season dry biomass of grassland in the African Sahel. Kennedy (1989) discovered that AVHRR-NDVI was strongly correlated with biomass and cover of range vegetation over a wide range of soil and topographic conditions in Tunisia.

Land managers, livestock producers, animal feed suppliers, and others are often interested in both forage quantity and quality. For example, a combination of forage quantity and quality attributes (standing nitrogen, $\mathrm{kg} \mathrm{N} \mathrm{ha}^{-1}$ ) was a good predictor of where cattle preferred to graze (Senft et al. 1985). Handheld radiometers have been used to estimate nitrogen concentration of plant tissue (Tucker 1979 , Plummer 1988). Researchers have not, however, examined the potential of AVHRR for assessing the quality of range forage. The purpose of this study was to investigate relationships between AVHRR-NDVI and measures of forage quality, and describe linear regression models for predicting both quantity and quality of forage in Montana rangelands.

\section{Materials and Methods}

\section{Study Areas}

Six study areas were established in 1997 on grasslands in southern and northern Montana. Grasslands were classified into 2 types: shortgrass prairie and foothill grassland, based on dominant vegetation (Mueggler and Stewart 1980). Selection of study sites in these 2 types of rangeland ensured that relationships between normalized difference vegetation index
(NDVI) and forage characteristics could be evaluated in a wide range of conditions during the summer grazing season.

Three of the study areas were established on foothill grassland: 1) $10 \mathrm{~km}$ east of Livingston, Mont. ( $45^{\circ} 41^{\prime} 48^{\prime \prime} \mathrm{N} 110^{\circ}$ 26' 05" W), 2) $20 \mathrm{~km}$ south of Havre, Mont. (Thackeray Ranch, $48^{\circ} 21^{\prime} 50^{\prime \prime} \mathrm{N}$ $109^{\circ} 35^{\prime} 00^{\prime \prime} \mathrm{W}$ ), and 3) $30 \mathrm{~km}$ southwest of Chinook, Mont. (Ross Ranch, $48^{\circ} 15^{\prime}$ $\left.46^{\prime \prime} \mathrm{N} 109^{\circ} 28^{\prime} 29^{\prime \prime} \mathrm{W}\right)$. Average annual precipitation for these 3 areas varies from 350 to $450 \mathrm{~mm}$ (Caprio et al. 1994). Dominant species includes rough fescue (Festuca scabrella Torr.), bluebunch wheatgrass (Pseudoroegneria spicatum (Pursh) A. Löve), western wheatgrass (Pascopyrum smithii (Rydberg) Löve), Idaho fescue (Festuca idahoensis Elmer), and bluegrass (Poa spp.). Hilltops are forested with Douglas fir (Pseudotsuga menziesii var. glauca (Bessin.) Franco) or ponderosa pine (Pinus ponderosa Dougl.). Vegetation along drainage bottoms includes chokecherry (Prunus virginiana L.), western snowberry (Symphoricarpos occidentalis Hook), and quaking aspen (Populus tremuloides Michx.) (Mueggler and Stewart 1980).

The 3 remaining study areas were established in shortgrass prairie: 1) $5 \mathrm{~km}$ west of Gardiner, Mont. (45 $01^{\prime} 21^{\prime \prime} \mathrm{N} 110^{\circ} 41^{\prime}$ 28" W), 2) $30 \mathrm{~km}$ northwest of Chinook, Mont. (48 42' 37' N $109^{\circ} 29^{\prime} 07^{\prime \prime} \mathrm{W}$ ), and 3) $10 \mathrm{~km}$ north of Zurich, Mont. ( $48^{\circ} 36^{\prime}$ $\left.33^{\prime \prime} \mathrm{N} 108^{\circ} 57^{\prime} 26^{\prime \prime} \mathrm{W}\right)$. These sites near Chinook and Zurich are characterized by terraces and glacial till plains with intermittent, dendritic drainages. Average annual precipitation is 250 to $300 \mathrm{~mm}$ (Caprio et al. 1994). Dominant species includes blue grama (Bouteloua gracilis (H.B.K.) Griffiths), western wheatgrass, and needle-and-thread (Stipa comata Trin. \& Rup.). Other grasses include Sandberg bluegrass (Poa sandbergii Vasey), and upland sedges (Carex spp.) (Mueggler and Stewart, 1980).

The pixel size of the advanced very high resolution radiometer (AVHRR) is $1 \times 1$ $\mathrm{km}$, but the potential error in registration between successive image scenes is up to 2 to 3 pixels. Usually the error is less than 1 pixel. The AVHRR image-to-image registration using automated correlation techniques improves geometric accuracy (root mean square less than 1 pixel) as compared to traditional image-to-map procedures (Eidenshink 1992). To enhance accuracy in the NDVI calibration effort, all study areas were situated within zones that comprised relatively homogenous vegetation. All study areas comprised 9 $\mathrm{km}^{2}$ ( $3 \times 3$ pixels of AVHRR) except for the site near Gardiner that measured only $1 \mathrm{~km}^{2}$ (1 pixel of AVHRR) Boundaries of this study area were specifically placed so that the center of the AVHRR pixel was in the geometric center of the site. The extent of homogeneous vegetation was not as extensive at the Gardiner location.

\section{Ground Sampling}

Mean standing crop of live and dead vegetation (live and dead biomass) and mean $\mathrm{N}$ concentration were estimated in early April and on a bi-weekly basis from May to October at the Gardiner and Livingston study areas. These vegetation attributes were estimated once per month from May to August at the other 4 study sites.

To maximize sampling efficiency, each study area was divided into smaller, relatively homogenous map units using a stratified sampling approach (Tucker et al. 1983, Townshend and Justice 1986, Tappan et al. 1992). Map units were delineated on 1:24,000 orthophotographs and topographic maps based on spatial patterns in vegetation, landform, and land use. At least 2 plots $\left(0.5 \mathrm{~m}^{2}\right)$ were randomly placed within a mapping unit. Study areas included at least 4 sampling units, and measurements were obtained from a total of 20 to 40 plots within each study area during each sampling period. Plots were clipped to ground level and clippings were separated in the field into standing live and dead plant tissue. Clipped plant parts that were green along $\geq 50 \%$ of their length were bagged as live material. Parts with $<50 \%$ green along their length were separated as dead material. Separations of plant material were made without regard to the identity of plant species because the spatial resolution of AVHRR imagery was too coarse for species level detail (Merrill et al. 1993, Kremer and Running 1993).

Clipped plant material was oven-dried at $50^{\circ} \mathrm{C}$ for 48 hours (Richardson et al.1983, Richardson and Everitt 1992). Total biomass was computed as the sum of the live and dead biomass after oven drying. Percent nitrogen by dry weight was determined on ignition with a LECO FP-328 combustion furnace (LECO Corp., St. Joseph, Mich.).

Live standing $\mathrm{N}$ was computed as the dry weight of live biomass multiplied by percent $\mathrm{N}$ in live biomass (Senft et al. 

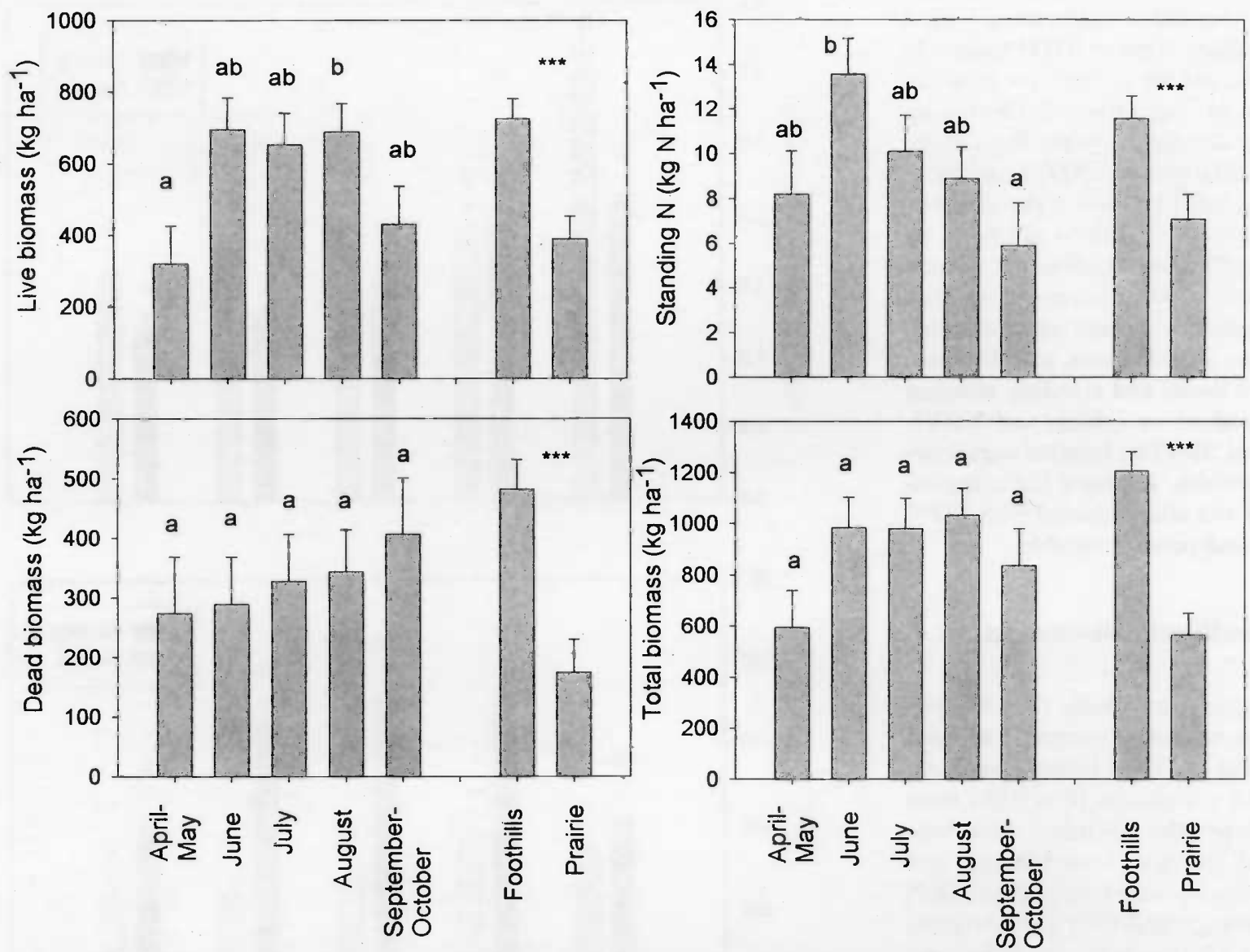

Fig. 1. Mean values of live biomass, dead biomass, total biomass and standing nitrogen for April or May, June, July, August, and September or October during the 1997 growing season $(n=33)$. Mean values of these dependent variables are also presented for foothills grassland and shortgrass prairie sites. Standard errors are presented for each mean. Monthly means without common superscripts differ $(P<0.05)$. Means for foothill grassland and shortgrass prairie sites differ if superscripts are presented $(* *=\mathbf{P}<0.01, * * *=\mathbf{P}<0.001)$.

1985). Mean values of the biomass (live, dead, and total), $\mathrm{N}$ concentration of live biomass and standing $\mathrm{N}$ were determined for each sampling event within each map unit. These mean values were then spatially weighted by the percentage of the study area comprised by each map unit. Mean biomass, standing $\mathrm{N}$ and $\mathrm{N}$ concentration for study area during a given sampling period were calculated from the spatially weighted means for each map unit.

\section{Regression Model for Estimating Forage Quantity and Quality}

Maximum value composite AVHRRNDVI images were obtained from the USGS EROS Data Center in Sioux Falls, S. Dak. Maximum value composite imagery is based on the maximum NDVI value for each pixel of imageries acquired daily over a 2 -week period (Holben 1986) and is used to compensate for variable atmosphere conditions. Raw NDVI values can vary from -1.0 to 1 , and in this study NDVI values for each pixel were scaled so that the range was 0 to 200 using the following equation.

$$
\mathrm{NDVI}=\left(\mathrm{NDVI}_{\mathrm{raw}}+1\right) * 100
$$

In addition, imagery is geometrically registered to a common map projection to enable image-to-image registration. Thus, land managers, who are mainly interested in the data for vegetation assessment and monitoring, are freed from preprocessing the raw data.

Live biomass, dead biomass, total biomass, nitrogen concentration, standing nitrogen, and NDVI estimates from on the ground measurements at each site were evaluated using a model that contained site type (foothill or prairie), month (April-May, June, July, August, and September-October) and the site type by month interaction (SAS 1985). Measurements collected during April and May were pooled together because there were fewer measurements collected in these months and they represented similar forage conditions typical of spring conditions. Similarly, those collected in September and October were pooled together and represented conditions often observed in autumn. Tukey's studentized range test was used for mean separation (Steel and Torrie 1980). We computed the arithmetic mean from the NDVI values from the 9 pixels comprising the study areas $\left(9 \mathrm{~km}^{2}\right)$ and considered it representative of the real NDVI value for each study site. The value of a single pixel was used for the study area near Livingston that measured $1 \mathrm{~km}^{2}$.

Estimates of biomass and $\mathrm{N}$ content that were then were regressed on NDVI values. Because the study areas were expected to differ in terms of vegetation and climate, location was evaluated as a fixed effect in PROC GLM of SAS (SAS 1985). This 
variable was used to test if the absolute values in vegetation parameters varied among locations at given NDVI values. In other words, did the $y$-intercepts from the regression of vegetation attributes on NDVI vary among locations? In addition, the interaction between NDVI and location was included as a test if the slopes of the regression of vegetation attributes on NDVI varied among locations (Timm and Mieczkowski 1997). Therefore, we constructed a predictive model where standing live biomass, dead biomass, total biomass, $\% \mathrm{~N}$ of live tissue and standing nitrogen were dependent variables, and NDVI, location, and NDVI by location were independent variables. A simple linear regression model was also evaluated with NDVI as the only independent variable.

\section{Results and Discussion}

Live biomass was greater $(\mathrm{P}<0.05)$ in August than when first measured in April and May (Fig. 1). Dead biomass and total biomass did not change $(P>0.05)$ from April to September-October. Live biomass, dead biomass, total biomass and standing nitrogen were greater $(\mathrm{P}<0.001)$ on foothill grassland than on shortgrass prairie (Fig. 1). This difference in biomass was likely the result of site differences in precipitation. Foothills grassland typically receives 100 to $250 \mathrm{~mm}$ more rainfall than shortgrass prairie. Live biomass in June was greater $(\mathrm{P}<0.05)$ than during August. Standing nitrogen in June was greater $(\mathrm{P}=$ 0.05) than during September-October. The interaction between site type and month of collection was not important $(P>0.1)$ for live biomass, dead biomass, total biomass, and standing nitrogen. However, there was an interaction between site type and month of collection for plant nitrogen concentration $(P=0.003)$ and NDVI $(P=0.04)$, and monthly means from each site type were evaluated separately. For foothill grassland sites, nitrogen concentration in April-May was greater $(\mathrm{P}<0.05)$ than measurements collected in July, August, and September-October (Fig. 2). Nitrogen concentration in June was greater $(\mathrm{P}<$ 0.05 ) than measurements collected in August and September-October. For shortgrass prairie, plant nitrogen concentration was greater $(\mathrm{P}<0.05)$ in April-May than other months. For foothill grassland, NDVI was greater $(\mathrm{P}<0.05)$ in June than in September-October (Fig. 2). For shortgrass
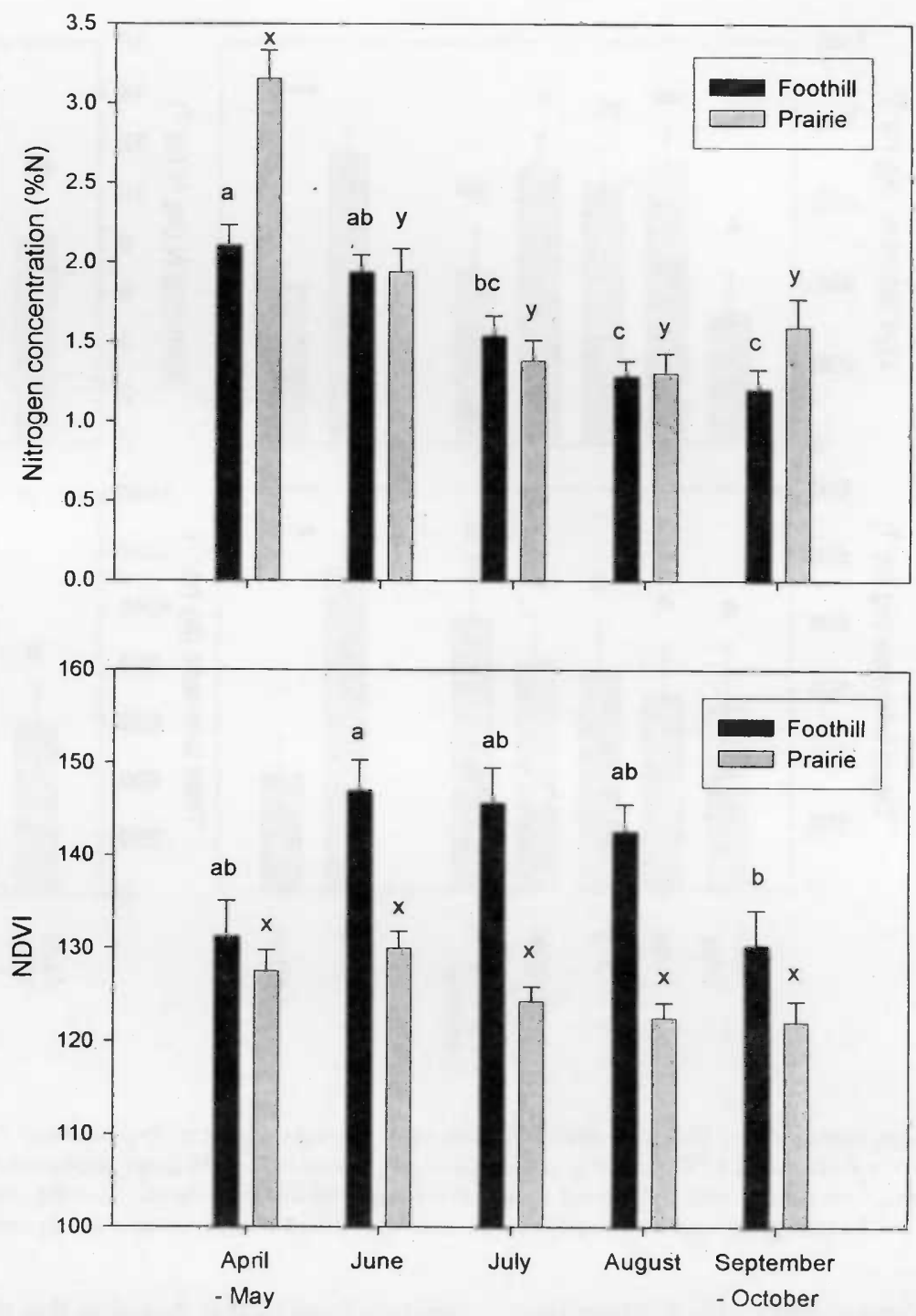

Fig. 2. Mean values of nitrogen concentration and NDVI for April or May, June, July, August and September or October for foothill grassland and shortgrass prairie sites during the 1997 growing season $(n=33)$. Standard errors are presented for each mean. There was an interaction $(P<0.05)$ between month of measurement and site type, and comparisons of monthly means were separately made for each site type. Monthly means from foothill grassland (black bars) without common superseripts $(\mathrm{a}, \mathrm{b}, \mathrm{c})$ differ $(\mathbf{P}<0.05)$. Monthly means from shortgrass prairie sites (gray bars) without common superscripts $(x, y)$ differ $(\mathbf{P}<0.05)$.

prairie, NDVI tended $(\mathrm{P}=0.06)$ to vary among months. Changes in NDVI more closely followed the patterns observed in live biomass and standing nitrogen, which combines both live biomass and nitrogen concentration. We anticipated that NDVI would be associated with live biomass and standing nitrogen because greenness of plant foliage has been found to be highly representative of photosynthetic capacity and efficiency (Richardson et al. 1983, Tucker et al. 1983, Plummer 1988, Benedetti and Rossini 1993).

Effects of location and the interaction between NDVI and locations were not significant $(P>0.05)$ in the initial regression model for all dependent variables. Consequently, data were pooled, and a simple linear regression model containing only NDVI was used to analyze the data. As in this study, Wylie et al. (1995) used a single relationship between AVHRRNDVI and biomass to assign pastoral zones of Niger into 3 classes of rangeland.

In simple linear regression models, NDVI explained $63 \%$ of the statistical variation in both total and live biomass, $18 \%$ in dead biomass, and $66 \%$ in stand- 

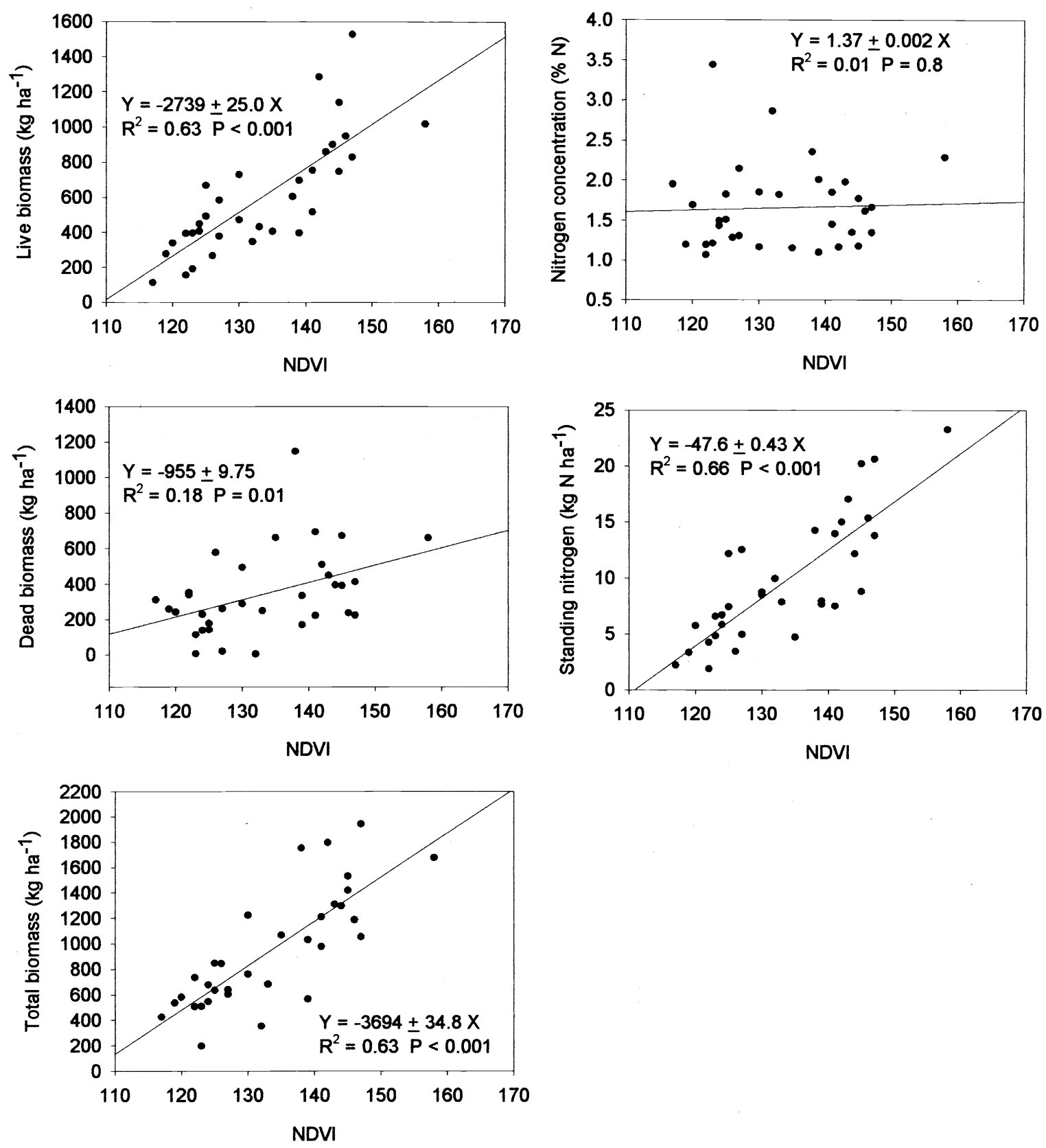

Fig. 3. Scatter plots of live, dead and total biomass, nitrogen concentration and standing nitrogen versus NDVI values from AVHRR imagery. Simple regression lines of dependent variables (live biomass, dead biomass, total biomass, nitrogen concentration and standing nitrogen) on NDVI are also presented.

ing N (Fig. 3). Poor correlation between NDVI and dead biomass was not surprising given the sensitivity of this spectral index for green foliage. Wylie et al. (1995) reported that NDVI accounted for 67 to $80 \%$ of the variation in biomass in 3 of 4 years of their study in Niger. Plant nitrogen concentration was not related $(\mathrm{P}=$ 0.8 ) to NDVI (Fig 3). Differences in NDVI resulting from variable biomass levels across sites and sampling times may have overwhelmed any effects of nitrogen concentration on NDVI.

When the simple linear regression was restricted to the period when range vegetation reached peak growth (1 June to 15 July), model results improved slightly. For live biomass, the $y$-intercept was $-1475 \pm$ 537 , and the slope was $15.9 \pm 3.9\left(\mathrm{R}^{2}=\right.$ $0.71, \mathrm{P}=0.005)$ as compared to $-2739+$
463 and $25.0 \pm 3.5$, respectively, for the entire data set (Fig. 3). For total biomass, the $y$-intercept for peak growth was -2896 \pm 717 and the slope was $28.1 \pm 5.2\left(\mathrm{R}^{2}=\right.$ $0.81, \mathrm{P}=0.001)$ as compared to $-3694 \pm$ 635 and $34.8 \pm 4.8$, respectively, for the entire data set (Fig. 3). This improvement is probably due to radiometric dominance of live vegetation, which tends to be stronger than that of soil background and 
dead biomass in that time of year. These results suggest that peak growth (June and early July in our study) is a good time period to use NDVI to predict and compare total annual vegetative growth within a region.

In this study, relationships between NDVI and standing live biomass or standing $\mathrm{N}$ were based on model calibration at 6 study sites with ground data collected throughout the growing season. These models may need to be calibrated periodically to account for variation in local climate and range vegetation phenology. However, any adjustments should be small because regression coefficients (intercept and slope of live, dead or total biomass and standing nitrogen on NDVI) from the limited peak growth period (June and early July) in this study were similar in order of magnitude to those obtained from the entire data, and the relationship between the dependent vegetative variables and NDVI did not vary among site types. The interaction between site types and NDVI was not significant in this study. In addition, the relationship between total biomass and NDVI observed by Kennedy (1989) in Tunisia was similar to observed in Montana for standing crops up to $2500 \mathrm{~kg}$ $\mathrm{ha}^{-1}$ when similar regression models were applied. Intercepts were $-3741 \pm 1220$ and $-3693 \pm 695$ and slopes were $43.5 \pm 11.6$ and $34.8 \pm 4.8$ in the Tunisia and Montana studies, respectively. Confidence intervals (95\%) of regression coefficients between NDVI and total biomass overlapped in all but 1 year of a 5-year study conducted by Wylie et al. (1992).

Relationships between forage characteristics and NDVI were linear over a relatively wide range of vegetative productivity levels (300 to $1300 \mathrm{~kg} \mathrm{ha}^{-1}$ in mean live biomass) within the 2 major grassland community types studied. If live biomass falls below $250 \mathrm{~kg} \mathrm{ha}^{-1}$, spectral responses of bare soil and dead biomass may dominate and result in underestimation of live biomass (Tucker and Vanparet 1985). If biomass levels are high and plant canopy is relatively closed, live biomass may be overestimated, plant canopy closure is high (Carneggie et al. 1983, Box et al. 1989). Therefore, the model should not be used to extend predictions beyond the range of original data that were used to establish a linear relationship. Other factors that negatively influence NDVI-vegetation relationships include atmospheric attenuation, topographic complexity, and pixel misregistration in successive imagery (Smith et al. 1997).

Image processing and the use of NDVI rather than absolute reflectance values reduces the chance that temporal variation in atmospheric conditions could result in the presumption of a change in forage conditions when in fact none occurred (Eidenshink 1992). Using the maximum NDVI value during a 2 -week interval theoretically reduces the effects of cloud-contaminated pixels and theoretically reduces the effects of atmospheric conditions associated with changes in nadir viewing angles (Holben 1986). Temporal variability in reflectance is also accounted for in the NDVI value because it is based on the relative difference in the reflectance of red and infrared wavelengths rather than the absolute values (Colwell 1974, Tucker et al. 1983).

The importance of AVHRR-NDVI lies in its ability to provide the temporal resolution needed for frequent monitoring of changes in the quality of green vegetation. By exploiting relationships between the NDVI and live biomass or standing N, land managers may be able to predict when and where shortfalls in higher quality vegetation may occur within extensive management units. Furthermore, the predictive ability of standing $\mathrm{N}$ by AVHRR data may allow managers to predict where livestock may graze. Senft et al. (1985) reported that cattle grazed in areas with greater standing $\mathrm{N}$. Cattle grazing was associated significantly more with standing $\mathrm{N}$ than with biomass or $\mathrm{N}$ concentration.

We conclude that maximum value composite AVHRR-NDVI imagery could produce reasonable estimates of live biomass and standing $\mathrm{N}$ at regional scales, when calibrated on ground data from 6 study sites within foothills grassland and shortgrass prairie areas of Montana. These results provided estimates of total forage quantity and more importantly the quantity of higher quality forage (live biomass and standing $\mathrm{N}$ ) that would otherwise have been time consuming to obtain with conventional ground surveys alone. However, AVHRR-NDVI was not a good predictor of forage quality as measured by nitrogen or crude protein concentration.

\section{Literature Cited}

Benedetti, R. and P. Rossini. 1993. On the use of NDVI profiles as a tool for agricultural statistics: The case study of wheat yield estimate and forecast in Emilia Romagna. Remote Sens. Environ. 45:311-326.
Box, E.O., B.N. Holben, and V. Kalio. 1989 Accuracy of the AVHRR Vegetation Index as a predictor of biomass, primary production and net $\mathrm{CO}_{2}$ flux. Vegetatio 80:71-89

Caprio, J.M., D.I. Cooksey, J.S. Jacobsen, G.A. Nielsen, and R.R. Roche. 1994. MAPS Atlas Version 5.0: A land and climate information system EB 125, Montana agricultural potentials system. Montana State Univ., Bozeman, Mont.

Carneggie, D.M, B.J. Schrumpf, and D.A. Mouat. 1983. Rangeland Applications. p. 2329-2359. In: Manual of Remote Sensing $\left(2^{\text {nd }}\right.$ ed.) Vol. II, R.N. Colwell (ed.), Amer. Soc. of Photogrammetry, Falls Church, Virg.

Colwell, J.E. 1974. Vegetation canopy reflectance. Remote Sens. Environ. 3:175-183.

Eidenshink, J.C. 1992. The 1990 conterminous U.S. AVHRR data set. Photogrammetric Eng. Remote Sens. 58:808-813.

Gutman, G.G. 1991. Vegetation indices from AVHRR: An update and future prospects. Remote Sens. Environ. 35:121-136.

Holben, B.N. 1986. Characteristics of maximumvalue composite images from temporal AVHRR data. Int. J. Remote Sens. 7:1417-1434.

Justice, C.O. and P.H.Y Hiernaux. 1986. Monitoring the grasslands of the Sahel using NOAA AVHRR data: Niger 1983. Int. J. Remote Sens. 7:1475-1497.

Kennedy, P. 1989. Monitoring the vegetation of Tunisian grazing lands using the normalized difference vegetation index. Ambio 18:119-123.

Kremer, R.G. and S.W. Running. 1993. Community type differentiation using NOAA/AVHRR data within a sagebrushsteppe ecosystem. Remote Sens. Environ. 46: 311-318

Merrill, E.H., M.K. Bramble-Brodahl, R.W. Marrs, and M.S. Boyce. 1993. Estimation of green herbaceous phytomass from Landsat MSS data in Yellowstone National Park. J. Range Manage. 46:151-157.

Mueggler, W.F. and W.L. Stewart. 1980. Grassland and shrubland habitat types of western Montana. USDA Forest Serv., Gen. Tech. Rep. Int-66, Washington, D.C.

Plummer, S.E. 1988. Exploring the relationships between leaf nitrogen content, biomass and near-infrared/red reflectance ratio. Int. J. Remote Sens. 9:177-183.

Richardson, A.J. and J.H. Everitt. 1992. Using spectral vegetation indices to estimate rangeland productivity. Geocarto Int. 7: 63-69.

Richardson, A.J., J.H. Everitt, and H.W. Gausman. 1983. Radiometric estimation of biomass and nitrogen content of Alicia grass. Remote Sens. Environ. 13:179-184.

SAS. 1985. SAS user's guide: Statistics. SAS Inst., Inc. Cary, N.C.

Senft, R.L., L.R. Rittenhouse, and R.B. Woodmansee. 1985. Factors influencing patterns of cattle grazing behavior on shortgrass steppe. J. Range Manage. 38: 82-87.

Smith, P., S. Kalluri, S. Prince, and $\mathbf{R}$. DeFries. 1997. The NOAA/NASA Pathfinder AVHRR 8-KM Land Data Set. Photogrammetric Eng. Remote Sens. 63:12-31. 
Steel, R.G.D. and J.H. Torrie. 1980 . Principles and procedures of statistics: A biometrical approach, $2^{\text {nd }}$ Ed. McGraw-Hill Book Co. New York, N.Y..

Tappan, G.G., D.J. Tyler, M.E. Wehde, and D.G. Moore. 1992. Monitoring rangeland dynamics in Senegal with Advanced Very High Resolution Radiometer data. Geocarto Int. 1:87-98.

Timm, N.H. and T.A. Mieczkowski. 1997. Univariate and multivariate general models: theory and applications using SAS software. SAS Institute Inc, Cary, N.C.

Townshend, J.R.G. and C.O. Justice. 1986. Analysis of the dynamics of African vegetation using the normalized difference vegetation index. Int. J. Remote Sens. 7 1435-1445.
Tucker, C.J. 1979. Red and photographic infrared linear combinations for monitoring vegetation. Remote Sens. Environ. 8:127-150.

Tucker, C.J. and C.L Vanparet. 1985. Satellite remote sensing of total herbaceous biomass in the Senegalese Sahel: 1980-1984. Remote Sens. Environ. 17:233-249.

Tucker, C.J., C. Vanparet, E. Boerwinkel, and A. Gaston. 1983. Satellite remote sensing of total dry matter production in the Senegalese Sahel. Remote Sens. Environ. 13:461-474.

Tueller, P.T. 1989. Remote sensing technology for rangeland management applications. J. Range Manage. 42:442-453.

Vallentine, J.F. 1990. Grazing management. Academic Press, San Diego, Calif.
Wessman, C.A., D.S. Schimel, S. Archer, C.A. Bateson, B.H. Braswell, D.S. Ojima, and W.J. Parton. 1995. New technologies for remote sensing of ecosystem change in rangelands, p. 139-141. In: N. E. West (ed.), Proc. Fifth Int. Rangeland Congress Soc. Range Manage. Denver, Colo.

Wiegand, C.L. and A.J. Richardson. 1990. Use of spectral vegetation indices to infer leaf area, evapotranspiration, and yield: I. Rationale. Agron. J. 82:623-629.

Wylie, B.K., J.A. Harrington, R.D. Pieper, and I. Denda. 1992. A satellite-based range assessment system for the Sahel of Africa. Geocarta Int. 1:79-85.

Wylie, B.K., I. Denda, R.D. Peiper, J.A. Harrington, B.C. Reed, and G.M. Southward. 1995. Satellite-based herbaceous biomass estimates in the pastoral zone of Niger. J. Range Manage. 48:159-164.

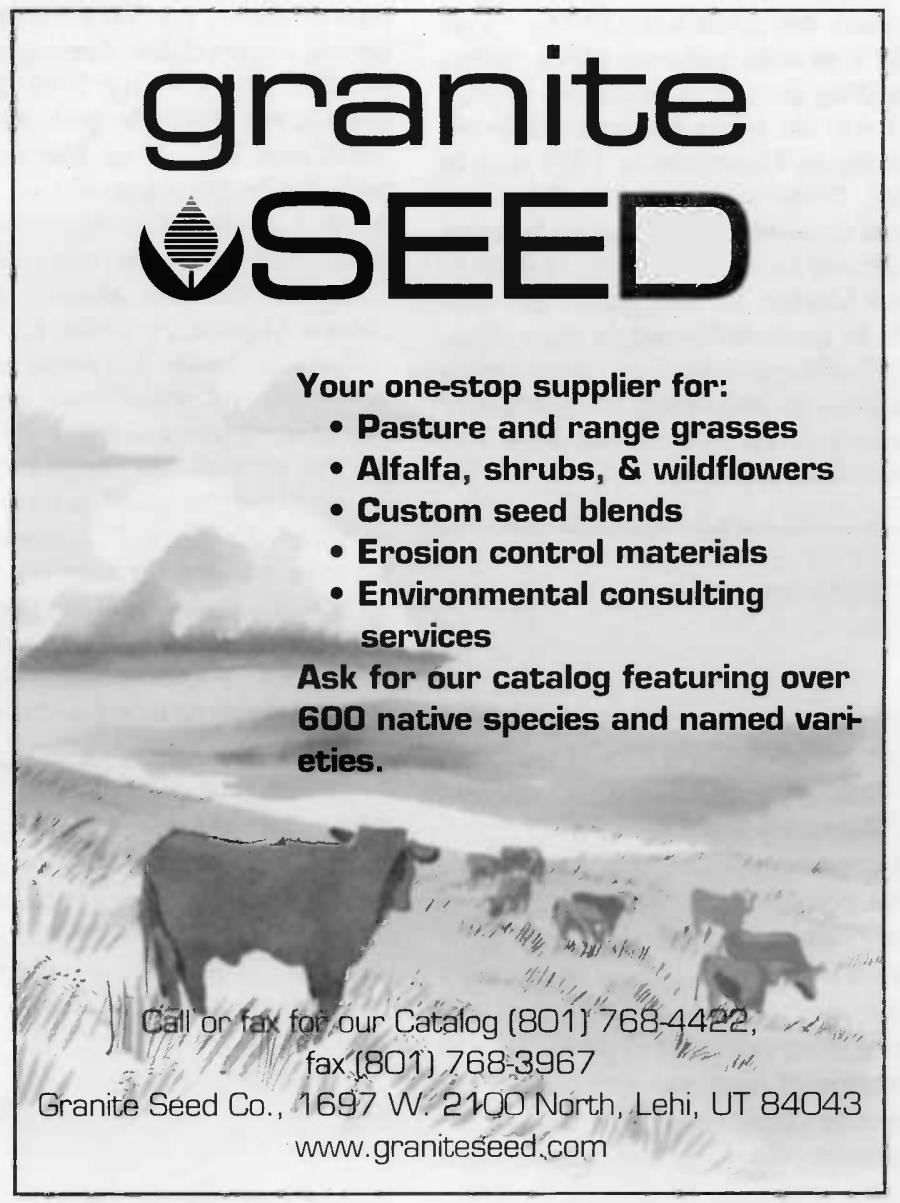




\title{
Prior feeding practices do not influence locoweed consumption
}

\author{
M.H. RALPHS, G. GREATHOUSE, A.P. KNIGHT, D. DOHERTY, J.D.GRAHAM, B.L. STEGELMEIER, AND L.F. \\ JAMES
}

Authors are Rangeland Scientist, USDA/ARS Poisonous Plant Lab, Logan Ut 84341; Ranch Manager, CSU Research Foundation; Dept. Head, Clinical Sciences Dept.; former graduate student, Animal Science Dept., Colorado State Univ., Ft. Collins Colo 80523;County Agent, Union County Extension, Clayton NM. 88415; Pathologist, and Research Leader, USDA/ARS Poisonous Plant Lab.

\begin{abstract}
Anecdotal evidence suggests that cattle fed alfalfa hay during the winter are inclined to graze locoweed on spring range. Two studies were conducted to compare the influence of feeding alfalfa hay vs grass hay during the winter on subsequent consumption of white locoweed (Oxytropis sericea Nutt. ex T\&G) in the spring. Eight cows were daily fed alfalfa hay $(15.2 \% \mathrm{CP}$ in $1998,17.1 \%$ $\mathrm{CP}$ in 2000) and 8 cows were daily fed grass hay $(10.7 \% \mathrm{CP}$ in $1998,12.1 \% \mathrm{CP}$ in 2000 ) plus $20 \%$ protein molasses block during the January-April winter feeding period. Treatment groups grazed in separate pastures $(8 \mathrm{ha})$ on white locoweed-infested range in May and June in northern Colorado in 1998 and in northeast New Mexico in 2000 . Diets were estimated by bite count. There was no difference in locoweed consumption between the 2 groups $(P>0.22)$. Cattle grazed locoweed for $5 \%$ of diets in Colorado and $10 \%$ of diets in New Mexico. Feeding alfalfa hay over winter did not predispose cattle to graze locoweed in the spring. Previous research showed other feeding practices or supplements do not affect locoweed consumption or poisoning. Prevention of locoweed poisoning requires denying access to locoweed when it is relatively more palatable than associated forages.
\end{abstract}

Key Words: Oxytropis sericea, alfalfa hay, grass hay, cattle, poisonous plant

Locoweeds (Astragalus and Oxytropis spp.) are the most destructive group of poisonous plants on western rangelands (Kingsbury 1964). Species of Astragalus and Oxytropis contain the toxic alkaloid swainsonine (Molyneux and James 1982) which inhibits essential enzymes in glycoprotein processing, resulting in buildup of unmetabolized hybrid glycoproteins and disruption of hormone and enzyme synthesis, transport and receptors (see Stegelmeier et al. 1999 for review). Outward effects on animals include reduced fertility of both males and females, abortions, neurological disturbances (ranging from extremes of depression to aggression), and impaired prehension of food and water, resulting in weight loss and eventual starvation (James et al. 1981).

Locoweed causes such an insidious poisoning that ranchers and researchers have attempted many practices to reduce the inci-

Authors wish to thank Jennifer Vaad and Becky Floyd for assistance in data collection, Joel Vaad in handling the animals, and Jane Chambers in running swainsonine analysis.

Manuscript accapted 1 Oct. 01.

\section{Resumen}

Evidencia anecdótica sugiere que el ganado bovino alimentado con heno de alfalfa durante el invierno tiende a consumir "locoweed" en pasturas naturales durante la primavera. Se condujeron dos estudios para comparar la influencia de ofrecer heno de alfalfa versus heno de gramineas durante el invierno sobre el posterior consumo de "locoweed" blanco (Oxytropis sericea Nutt. Ex T\&G) durante la primavera. Ocho vacas fueron alimentadas diariamente con heno de alfalfa (15.2\% PC en 1998, 17.1\% PC en 2000) y 8 vacas fueron alimentadas diariamente con heno de gramineas $(10.7 \%$ PC en $1998,12.1 \%$ en 2000) mas $20 \%$ de un bloque de proteina y melazas durante el periodo de alimentación de invierno que fue de Enero hasta Abril. Los grupos pastorearon en areas separadas (8 ha) en una pastura natural infestada con "locoweed" blanco en el norte de Colorado durante Mayo y Junio de 1998 y en el noreste de Nuevo Mexico en 2000. Las dietas fueron estimadas por el método de contar bocados. No existio diferencia en el consumo de "locoweed" entre los 2 grupos $(P>0.22)$. Los bovinos pastorearon "locoweed" por un $5 \%$ de sus dietas en Colorado y por un $10 \%$ de sus dietas en Nuevo Mexico. La oferta de heno de alfalfa durante el invierno no predispuso al ganado para pastorear "locoweed" durante la primavera. Investigación previa muestra que otras practicas de alimentación o suplementos no afectan el consumo de "locoweed" o la posibilidad de intoxicación con esta planta. La prevención de la intoxicación con "locoweed" requiere negar el acceso al "locoweed" cuando este es relativamente mas palatable que los forrajes asociados.

dence of poisoning. One practice that was thought to influence locoweed consumption was prior feeding of alfalfa during the winter. The objective of this study was to test the hypothesis that cattle fed alfalfa hay over the winter will graze more white locoweed (Oxytropis sericea Nutt. ex T\&G) on spring range than cattle wintered on grass hay.

\section{Methods}

\section{Winter feeding regimen}

Sixteen, 2-year-old first-calf heifers naive to alfalfa hay and white locoweed were randomly assigned to 2 treatment groups in winter 1998 at the Colorado State University Research Foundation Maxwell Ranch, $25 \mathrm{~km}$ north of Ft. Collins, Colo. $\left(40^{\circ} 56.39^{\prime} \mathrm{N}, 105^{\circ} 15.33^{\prime} \mathrm{W}\right)$. Animals were handled by methods 
approved by an Institutional Animal and Care Use Committee. One group was fed native meadow grass hay $(10.7 \% \mathrm{CP}$, as fed) and supplemented with $20 \%$ proteinmolasses block $\left(0.9 \mathrm{~kg} \mathrm{cow}^{-1}\right.$ day $\left.^{-1}\right)$. The other group was fed alfalfa hay $(15.2 \%$ $\mathrm{CP}$, as fed). Cattle had free-choice access to hay fed in round bales in feeders. Hay was fed from 11 February to 15 May 1998 , and all cows calved during this period. Average weight at the beginning of feeding was $375 \mathrm{~kg}$. Cows in the grass group lost $57 \mathrm{~kg}$, and those in the alfalfa group lost $32 \mathrm{~kg}$ during the feeding/calving period. Mean body condition score (scale 1-9) at the beginning of the grazing trial was 3.9 , and 4.1 for the grass and alfalfa-fed groups, respectively.

The cows were used on another locoweed grazing trial in 1999 (Ralphs et al. 2001), but were separated into their original groups and fed their respective rations (alfalfa vs grass hay) from 13 December 1999 to 16 May 2000 at the USDA/ARS Poisonous Plant Research facility at Logan, Ut. The cows were group-fed about $11 \mathrm{~kg} \mathrm{cow}^{-1} \mathrm{day}^{-1}$ of the respective hays from large rectangular bales. The orchard grass hay contained $12.1 \% \mathrm{CP}$ (as fed) and alfalfa hay contained $17.1 \% \mathrm{CP}$ (as fed). The cows weighed $536 \mathrm{~kg}$ at the beginning of the feeding period. The grass-fed group lost $53 \mathrm{~kg}$ while the alfalfa-fed group gained $63 \mathrm{~kg}$ and the condition scores were about 4 and 6 respectively. The cows were bred to calve in July and were in the late stage of gestation during the spring grazing period. Only 5 cows from each group were available for the 2000 grazing trial because of early calving and illness. There was little locoweed available at the Maxwell Ranch in Colorado because of severe drought, therefore the cattle were trucked to a site $10 \mathrm{~km}$ southwest of Capulin, N.M. $\left(30^{\circ} 41.25^{\prime} \mathrm{N}, 104^{\circ} 08.35^{\prime}\right.$ W) where white locoweed was abundant for the spring grazing trial.

\section{Spring locoweed grazing trials}

The 1998 grazing trial on the Maxwell Ranch in Colorado ran from 15 May to 18 June. The cows were fasted overnight, weighed, then turned onto locoweedinfested pasture. The range site was a mixed-grass prairie on shallow gravely sandy loam soil derived from weathered granite. Dominant cool-season grasses on the uplands included Needle-and-thread (Stipa comata Trin. \& Rupr.), prairie junegrass (Koleria macrantha (Ledeb) Schultes), and squirrel tail (Elymus elymoides (Raf.) Swezey), with western wheatgrass (E. smithii (Rybe.) Gould) dominating the swales. Warm-season grasses were minor components: blue grama (Bouteloua gracilis (H.B.K.) Lag. ex Steudel), purple 3-awn (Aristida purpurea Nutt), and ring muhly (Muhlenbergia torreyi (Kunth) Hitchc. Ex Bush). White locoweed was the dominant forb, with fringed sagewort (Artemisia frigida Willd), Utah milkvetch (Astragalus utahensis (Torr.)T.\&.G), rose pussytoes (Antennaria microphylla Rydb), geranium (Geranium richardsonii Fisch. \& Trautv.), and Penstemon spp. present.

Standing crop was estimated at the beginning and end of both trials by clipping the forage classes (cool-season grass, warm-season grass, forbs, and locoweed) in 1 by $.25 \mathrm{~m}$ quadrats placed systematically at 20 step intervals along 2 transects in each pasture (40 plots total). Standing crop of forage classes was compared between pastures and beginning and end of each study separately using analysis of variance.

Two, 8 ha pastures were fenced with temporary electric fence. The 2 groups were randomly assigned to a pasture and were rotated to the other pasture every week to reduce pasture bias. The cows were brought into an onsite corral at the end of each week and blood samples were taken by jugular venipuncture. Serum was separated, frozen and later analyzed for swainsonine (Stegelmeier et al. 1995) as a measure of intoxication.

Cattle diets were estimated using a bite count technique. Each cow was observed for 5- minute periods and the number of bites of forage classes were counted: coolseason grass, warm-season grass, forbs, and locoweed. The cows were observed during the early morning and evening grazing periods, and each cow was observed at least once during each period. Observations were made each day during the 5 week grazing trial.

The 2000 grazing trial was conducted near Capulin, N.M. and ran from 18 May to 13 June. The site was a short-grass prairie on a silty clay loam soil. Blue grama was the dominant warm-season

Table 1. Standing crop of forages classes $(\mathrm{kg} / \mathrm{ha} \pm \mathrm{SE})$ at the beginning and end of grazing trials in 1998 and 2000.

\begin{tabular}{|c|c|c|c|c|c|c|}
\hline Year & Time & $\begin{array}{c}\text { Cool-season } \\
\text { grass }\end{array}$ & $\begin{array}{c}\text { Warm-season } \\
\text { grass }\end{array}$ & Forb & Locoweed & Total \\
\hline 1998 & $\begin{array}{l}\text { Begin } \\
\text { End }\end{array}$ & $\begin{array}{l}422 \pm 86^{*} \\
202 \pm 47^{*}\end{array}$ & $\begin{array}{l}209 \pm 29 \\
209 \pm 32\end{array}$ & $\begin{array}{r}63 \pm 11 * * \\
63 \text { (kg/ha)--- } \\
156 \pm 26^{* *}\end{array}$ & $\begin{array}{r}121 \pm 27^{\mathrm{t}} \\
66 \pm 21^{\mathrm{t}}\end{array}$ & $\begin{array}{l}811 \pm 56 \\
633 \pm 57\end{array}$ \\
\hline 2000 & $\begin{array}{l}\text { Begin } \\
\text { End }\end{array}$ & $\begin{array}{l}356 \pm 59^{* *} \\
101 \pm 18^{* *}\end{array}$ & $\begin{array}{l}362 \pm 37^{* *} \\
576 \pm 45^{* *}\end{array}$ & $\begin{array}{r}139 \pm 31 \\
98 \pm 17\end{array}$ & $\begin{array}{l}553 \pm 107 \\
501 \pm 99\end{array}$ & $\begin{array}{l}1466 \pm 201 \\
1283 \pm 139\end{array}$ \\
\hline
\end{tabular}

Difference in standing crop of forage classes at the beginning and end of each study:

$* * \mathrm{P}<0.01, * \mathrm{P}<0.05, \mathrm{t} \mathrm{P}<0.10$. grass, and cool-season grasses consisted of patches of western wheatgrass and occasional plants of squirreltail. White locoweed was the dominant forb, with fringed sage, and 3 non-toxic Astragalus species inhabiting the site. The area was fenced into two, 8-ha pastures using temporary electric fence. The groups were randomly allocated to pastures, and rotated to the other pasture on a weekly basis to minimize pasture bias. Diets were estimated by bite counts as described above.

Data from the 2 trials were analyzed separately because location and year were totally confounded. Percentage of bites of forage classes were compared between the two groups in a repeated measures mixed model using compound symmetry covariate structure (SAS Inst. Inc., Cary, N.C). Cow-within-group was the experimental unit, group was the main factor and week was the repeated factor.

\section{Results}

White locoweed comprised $15 \%$ of the standing crop in the Colorado grazing trial in 1998 , and $38 \%$ in the New Mexico trial in 2000 (Table 1). The greater abundance of locoweed may have contributed to the higher consumption of locoweed at New Mexico compared to Colorado (Table 2). There was no difference in abundance of locoweed between pastures in either trial $(P>0.10)$. Locoweed was in the late vegetative stage at the beginning of the Colorado trial, and matured to the late flower stage at the end of the trial. Locoweed was more advanced in the 2000 trial in New Mexico, which began in the flower stage, but the flowers aborted and few pods were produced due to drought. Crude protein content of locoweed was $15 \%$ in 1998 and $12.6 \%$ in 2000 . Cool season grasses such as needle-and-thread, prairie junegrass and squirrel tail were abundant on the Colorado site in 1998 and dominated the standing crop. Blue grama, a warm season grass, dominated the site of the 2000 study at New Mexico and began its seasonal growth during during the trial. 
Table 2. Composition of cattle diets estimated by a bite count technique $( \pm \mathrm{SE})$.

\begin{tabular}{llcccr}
\hline \hline Year & Group & Cool-season grass & Warm-season grass & Forb & Locoweed \\
\hline \multirow{2}{*}{1998} & Alfalfa & ---------1.3 & $8 \pm 0.8$ & $6 \pm 0.5$ & $5 \pm 0.8$ \\
& Grass & $-80 \pm 1.2$ & $8 \pm 0.9$ & $7 \pm 0.6$ & $4 \pm 0.5$ \\
2000 & Alfalfa & $36 \pm 1.5$ & $36 \pm 1.4$ & $19 \pm 0.9$ & $8 \pm 1.0$ \\
& Grass & $37 \pm 1.6$ & $30 \pm 1.3$ & $20 \pm 1.0$ & $13 \pm 1.4$ \\
\hline
\end{tabular}

There was no difference between groups in any of the forage classes in either year $(P>0.05)$.

The cool season grasses, western wheatgrass and squirreltail, were heavily grazed during the 2000 trial. There were no differences in standing crop of forage classes between pastures within the 2 grazing trials $(\mathrm{P}>0.05)$.

There was no difference in locoweed consumption between treatment groups in either year $(P>0.22)$. Mean locoweed consumption in the 1998 trial was $5 \%$ and $4 \%$ of bites for the alfalfa and grass hay groups, respectively; and $8.2 \%$ and $13.4 \%$, respectively in the 2000 trial (Table 2). However, there was a group by week interaction in the 1998 trial $(\mathrm{P}=$ $0.0001)$. The grass group started eating locoweed before the alfalfa group during the second week of the trial ( $9 \%$ of bites), but the alfalfa group consumed more locoweed $(21 \%$ of bites) during the 3 rd week (Fig. 1). Locoweed consumption declined during the last 2 weeks of the 1998 trial as locoweed matured and its availability declined.

Cattle began consuming locoweed at the beginning of the 2000 trial (10-20\% of bites, Fig. 1). Locoweed consumption declined in week 3 , but then increased during the last 2 days of the trial. In previous locoweed grazing trials on short-grass prairies in northeastern New Mexico (Ralphs et al. 1993, 1997a, 1997b), cattle reduced locoweed consumption in late May and early June and ceased grazing it as it matured into the pod stage and warm-season grasses began rapid growth. In another study at the Colorado site, cattle ceased grazing white locoweed as it matured into the mature pod stage in July 1998, but continued to consume its leaves throughout the summer in 1999 (Ralphs et al. 2001). Summer rains were above average in 1999 in Colorado and the leaves of white locoweed remained green and succulent.

Cool-season grasses were abundant and dominated cattle diets in 1998 at Colorado (Table 2). Warm season grasses were the dominant forage class at New Mexico, and diets were evenly split between cool-season grass that had matured, and warm-season grasses that were beginning to grow rapidly. Cattle preferred and sought-out the low growing, nontoxic Astragalus species and other forbs in the 2000 trial (Table 2).

There was a moderate correlation between swainsonine in the blood and locoweed consumption $(r=0.79)$ in the 1998 trial. When the groups were compared separately, the alfalfa group had a stronger correlation $(\mathrm{r}=0.82)$ compared to the grass group $(r=0.67)$. Swainsonine in the blood followed locoweed consumption of the alfalfa group very closely (Fig. 2). Swainsonine in the grass group dropped in week 3 to a greater extent than the bite counts indicate. Swainsonine is cleared rapidly from the blood (Stegelmeier et al. 1995). Therefore, the drop in swainsonine was due to a decline in locoweed consumption during the latter part of that week, whereas the higher consumption of locoweed at the beginning of the week kept the weekly average consumption elevated.

There were no clinical signs of poisoning during either study. Cattle must graze locoweed for 10 to $25 \%$ of their diets for 3-4 weeks before signs of poisoning are apparent. The high levels of locoweed consumption and swainsonine in the blood
1998 study
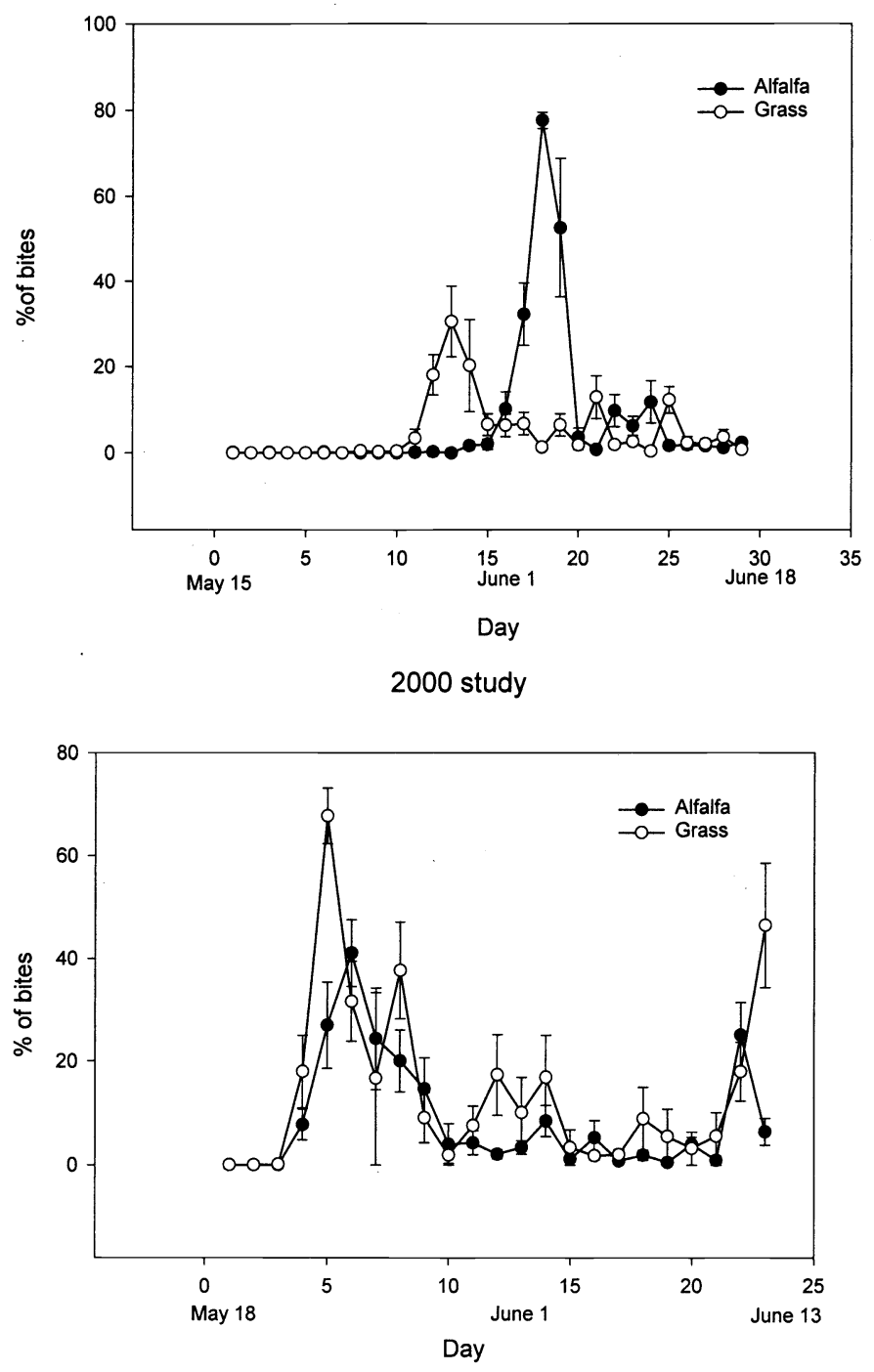

Fig. 1. Daily consumption of locoweed by cattle in the alfalfa and grass - fed groups in the 1998 and 2000 grazing trials (alfalfa group obscured by open circles during first 10 days of the 1998 trial). 


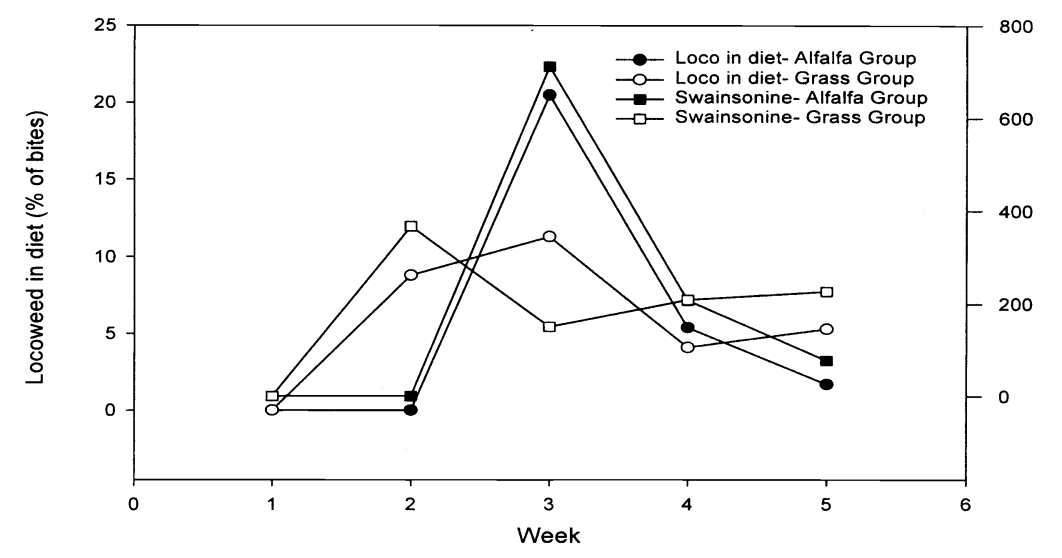

Fig. 2. Relationship between locoweed consumed (as estimated by bite counts) and swainsonine level in the blood in the 1998 grazing trail.

during these trials were not sustained for sufficient time to poison these animals.

\section{Discussion}

Cattle fed alfalfa hay during the winter did not consume more locoweed in the spring and early summer than cattle fed grass hay. Despite differences in nutritional plane or body condition, there was no difference in subsequent locoweed consumption. The notion that alfalfa (a highly nutritious legume) predisposes cattle to graze locoweed (also a highly nutritious legume) was unsubstantiated in this study. Other anecdotal evidence suggested that cattle wintered on green winter wheat are prone to graze locoweed when turned onto shortgrass prairie in the spring, based on the assumption that cattle accustomed to eating green forage would continue to seek out green-growing locoweed. A previous grazing trial showed there was no difference in locoweed consumption between cows wintered on wheat pasture or native range (Ralphs et al. 1997b).

Many minerals and feed additives have been investigated looking for "silver bullets" to prevent poisoning. Mineral supplements did not prevent poisoning, nor delay symptoms in sheep fed Garboncillo (Astragalus wootonii Sheld) (James and VanKampen 1974), or prevent cattle from grazing white locoweed (Allison and Graham 1999). Clay minerals have some scientific theory for their use since their differing electrical charges may bind to swainsonine, but a variety of clays and minerals were not effective in preventing or reducing locoweed poisoning (Bachman et al. 1992, Pulsipher et al. 1994). Neither did vitamin E/selenium injections hasten recovery from locoweed poisoning
(Richards et al. 1999). This is not to say that mineral supplements should not be used. Where minerals are deficient in forage, supplements should be used to maintain animal health, but they are unlikely to prevent locoweed poisoning.

There was also concern that implants which stimulate growth may enhance locoweed poisoning. Implants increase intake and rate of gain, thus animals may graze less selectively and/or consume more locoweed. On the other hand, estrogen from implants may provide some neurological protection. An estradiol implant did not cause steers to select more locoweed in a grazing trial, and did not affect the degree of poisoning or rate of recovery in a locoweed feeding trial (Mikus et al. 2001).

\section{Management Implications}

Cattle fed alfalfa during the winter did not consume more locoweed in the spring and early summer than cattle fed grass hay. Previous research indicated that other preconditioning feeding practices or supplements have not prevented cattle from grazing locoweed. Prevention of locoweed poisoning at this point in time lies in not allowing animals to graze locoweedinfested areas when it is relatively more palatable than associated forages.

\section{Literature Cited}

Allison, C. and J.D. Graham. 1999. Reducing locoism with management decisions. pp. 64-66 In: T.M. Sterling and D.C. Thompson (eds), Locoweed Research Updates and Highlights, New Mexico Agr. Exp. Sta. Res. Rep. 730. Las Cruces, N.M.
Bachman, S.E., M.L. Galyean, G.S. Smith, D.M. Hallford, and J.D. Graham. 1992. Early aspects of locoweed toxicosis and evaluation of a mineral supplement or clinoptilolite as dietary treatments. J. Anim. Sci. 70:3125-3132.

James, L.F. and K.R. VanKampen. 1974. Effect of protein and mineral supplementation on potential locoweed poisoning in sheep. J. Amer Vet. Med. Assoc. 164:1043-1043.

James, L.F., W.J. Hartley, and K.R. VanKampen. 1981. Syndromes of Astragalus poisoning in livestock. J. Amer. Vet. Med. Assoc. 178:146-150.

Kingsbury, J.M. 1964. Poisonous Plants of the United States and Canada. Prentice-Hall, Entlewood Cliffs, N.J.

Mikus, J.H., G.C. Duff, C.R. Krehbiel, D.M. Hallford, D.A. Walker, J.D. Graham, and M.H. Ralphs. 2001. Effects of an estradiol implant on locoweed consumption, toxicity, and recovery in growing beef steers. Prof. Anim. Sci.17:109-114

Molyneux, R.J. and L.F. James. 1982. Loco intoxication: indolizidine alkaloids of spotted locoweed. Sci. 216:190-191.

Pulsipher, G.D., M.L. Galyean, D.M. Hallford, G.S. Smith, and D.E. Kiehl. 1994. Effects of graded levels of bentonite on serum clinical profiles, metabolic hormones, and serum swainsonine concentrations in lambs fed locoweed (Oxytropis sericea). J. Anim. Sci. 72:1561-1569.

Ralphs, M.H., D. Graham, M.L. Galyean, and L.F. James. 1997a. Creating aversions to locowed in naive and familiar cattle. $J$. Range Manage. 50:361-366.

Ralphs, M.H., D. Graham, M.L. Galyean, and L.F. James. 1997b. Influence of overwintering feed regimen on consumption of locoweed by steers. J. Range Manage. 50:250-252.

Ralphs, M.H., D.Graham, R.J. Molyneux, and L.F. James. 1993. Seasonal grazing of locoweeds by cattle in northeastern New Mexico. J. Range Manage. 46:416-420.

Ralphs, M.H., G. Greathouse, A.P. Knight and L.F. James. 2001. Cattle preference for lambert locoweed over white locoweed. J. Range Manage. 54:265-268.

Richards, J.B., D.M. Hallford, and G.C. Duff. 1999. Serum luteinizing hormone, testosterone, and thyroxine and growth responses of ram lambs fed locoweed (Oxytropis sericea) and treated with vitamin E/selenium. Theriogenology 52:1055-1066.

Stegelmeier, B.L., L.F. James, K.E. Panter, and R.J. Molyneux. 1995. Serum swainsonine concentration and $\alpha$-mannosidase activity in cattle and sheep ingesting Oxytropis sericea and Astragalus lentiginosus. Amer. J. Vet. Res. 56:149-154.

Stegelmeier, B.L., L.F. James, K.E. Panter, M.H. Ralphs, D.R. Gardner, R.J. Molyneux, and J.A. Pfister. 1999. The pathogenesis and toxicokinetics of locoweed poisoning in livestock. J. Natural Toxins $8: 35-45$. 


\title{
Clipping and precipitation influences on locoweed vigor, mortality, and toxicity
}

\author{
M.H. RALPHS, D.R. GARDNER, J.D. GRAHAM, G. GREATHOUSE, AND A.P. KNIGHT
}

Authors are Rangeland Scientist, USDA/ARS Poisonous Plant Lab, Logan Ut. 84341; Chemist, USDA/ARS Poisonous Plant Lab, Logan, UT 84341; Extension Agent, Union County Extension, Clayton, N.M. 88415; Ranch Manager, CSU Research Foundation Maxwell Ranch; and Chair, Clinical Sciences Dept., Colorado State Univ. , Ft. Collins, Colo. 80523.

\begin{abstract}
White locoweed (Oxytropis sericea Nutt. in T\&G) is widespread throughout the short-grass prairies and mountain grasslands and causes chronic poisoning of cattle, sheep, and horses. The objective of this study was to determine the effect of clipping (simulated grazing) on vigor, mortality and toxic alkaloid concentration of white locoweed. One hundred locoweed plants were marked at each of 3 locations (New Mexico, Colorado, and Utah). Plants were stratified into 2 age/size classes: young/small $<5$ stalks; older/large $>7$ stalks $(n=50$ in each class). Pairs of plants within each age class that were as similar as possible were selected, and 1 of each pair $(n=25)$ was clipped at ground level annually for 4 years. Vigor indices included number of stalks, number of flowering heads, leaf length, and flowering head height. Mortality was recorded and the toxic alkaloid swainsonine was measured. Clipping did not consistently reduce vigor. Flowering heads/plant declined in most clipped plants $(P<0.05)$, but stalks/plant declined only in large clipped plants in Utah and small clipped plants in New Mexico $(P<0.01$ ), and clipping did not greatly affect leaf length or flowering head height. Clipping did not increase mortality, and did not affect swainsonine concentration. However, there was a natural die-off that may have been related to precipitation. There were negative correlations between precipitation and locoweed mortality $(r=-0.42$ to -0.84$)$, with most of the marked plants dying during the recent drought. Grazing locoweed for short periods would likely not affect its vigor or toxicity, but its population dynamics were affected by drought.
\end{abstract}

Key Words: white locoweed, Oxytropis sericea, poisonous plant, population cycle

White locoweed (Oxytropis sericea Nutt. in $\mathrm{T} \& \mathrm{G}$ ) is the most widespread locoweed on western U.S. rangelands, and causes chronic poisoning in grazing livestock and wildlife. It is relatively palatable in the spring and fall when warm-season grasses are dormant, and signs of poisoning appear when animals consume it for 3-4 weeks. It inhabits shortgrass prairies along the foothills of the Rocky Mountains and high mountain grasslands, and typically occurs on shallow or rocky soils (Payne 1957, Ralphs and Cronin 1987). White locoweed is considered an increaser species (i.e. increasing in density as range condition declines from good to fair condition, but decreasing as excessive grazing pressure causes further deterioration from fair to poor condition, Payne 1957).

\footnotetext{
Manuscript accepted 14 Sept. 01.
}

\section{Resumen}

El "White locoweed" (Oxytropis sericea Nutt. in T\&G) esta dispersa a través de las praderas de zacates cortos y los zacatales de montaña y causa un envenenamiento crónico a los bovinos, ovinos y equinos. El objetivo de este estudio fue determinar el efecto del corte (apacentamiento simulado) en el vigor, mortalidad y concentración de alcaloides tóxicos del "White locoweed". Cien plantas de "White locoweed" fueron marcadas en cada una de 31 localidades (New Mexico, Colorado y Utah). Las plantas se estratificaron en dos clases de tamaño/edad: jóvenes/pequeñas < 5 tallos; grandes/viejas $>7$ tallos $(n=50$ en cada clase). Dentro de cada clase de edad se seleccionaron pares de plantas lo mas similares posible, $y$ una planta de cada par $(n=25)$ se cortó anualmente a nivel del suelo durante 4 años. Los indices de vigor incluyeron el número de tallos, número de inflorescencias, longitud de la hoja y altura de la inflorescencia. Se registró la mortalidad y se midió la concentración del alcaloide swansonina. EI corte no reduce en forma consistente el vigor. Las inflorescencias/planta disminuyeron en la mayoría de las plantas cortadas $(P<0.05)$, pero el número de tallos /planta se redujo solo en las plantas grandes cortadas en Utah y las pequeñas cortadas en New Mexico $(P<0.01)$ y el corte no afectó grandemente la longitud de las hojas y la altura de la inflorescencia. El corte no incrementó la mortalidad ni afectó la concentración de swansonina. Sin embargo, hubo una mortalidad natural que puede haber estado relacionada con la precipitación. Hubo correlaciones negativas entre la mortalidad de "locoweed"y la precipitación $(r=-$ 0.42 to-0.84), la mayoría de las plantas marcadas murieron durante la sequía reciente. El apacentamiento de "Locoweed" por periodos cortos de tiempo probablemente no afectaría su vigor o toxicidad, pero su dinámica de población fueron afectadas por la sequía.

Weeds that are not readily grazed have a competitive advantage over palatable grasses that are frequently defoliated. However, if animals could be forced to graze weeds, this additional stress may reduce their competitive ability and naturally reduce their stature and abundance in the plant community. Furthermore, on-off grazing (short intense periods grazing locoweed then removing the animals to allow for detoxification), has been proposed as a grazing strategy to reduce locoweed poisoning (Pfister et al. 1996). This type of a high-intensity, short-duration grazing system may force livestock to uniformly graze all forage in a pasture, thus increasing grazing pressure on locoweed. The objective of this study was to evaluate the influence of defoliation on the vigor, mortality and toxic alkaloid concentration of white locoweed. 
Weather data were available from nearby stations and correlations were made between precipitation and mortality to determine the influence of drought on these parameters.

\section{Methods}

Three locations were selected that had histories of cattle loss to white locoweed. The first site was $5 \mathrm{~km}$ west of DesMoines, New Mexico (N 36 45.23', W $103^{\circ}$ $\left.51.00^{\prime}\right)$, at an elevation of $2,200 \mathrm{~m}$. Soils were silty clay loam with interspersed outcroppings of volcanic basalt rock and a gentle southern exposure. Major grasses consisted of blue grama [Bouteloua gracilis (H.B.K.) Lag. ex Steudel], sideoats grama [B. curtipendula (Michx.) Torr.], little bluestem [Schizachyrium scoparium (Michx.) Nash], and western wheatgrass [Elymus smithii (Rybd.) Gould]. White locoweed was the dominant forb. Weather data were obtained from the Capulin National Monument, about $13 \mathrm{~km}$ from the study site.

The second site was on the Colorado State Univ. Research Foundation Maxwell Ranch, located $40 \mathrm{~km}$ northwest of Fort Collins, Colo. (N $40^{\circ} 54.73^{\prime}, \mathrm{W} 105^{\circ}$ $\left.16.33^{\prime}\right)$ at an elevation of $2,000 \mathrm{~m}$. Soils were a shallow gravely loam with a gently sloping west exposure. Associated grasses included needle-and-thread (Stipa comata Trin. \& Pupr.), squirreltail (Elymus elymoides Raf. Swezey), prairie June grass (Koeleria macrantha (Ledeb.) Schultes) and blue grama. Weather data were obtained from the Virginia Dale weather station $6 \mathrm{~km}$ from the study site.

The third site was on top of the Raft River mountains in northwest Utah ( $\mathrm{N} 41^{\circ}$ $55.61^{\prime}, \mathrm{W} 113^{\circ} 24.42^{\prime}$ ) at an elevation of $3,000 \mathrm{~m}$. Soils were shallow loam (10-25 $\mathrm{cm}$ to bedrock), with 35 to $65 \%$ coarse fragments. The plant community was dominated by alpine sagebrush (Artemesia scopulorum Gray), muttongrass (Poa fendleriana (Steud.) Vasey), and Idaho fescue (Festuca idahoensis Elmer). Weather data was obtained from the nearest station at Grouse Creek, about $25 \mathrm{~km}$ west of the study site and 1,200 $\mathrm{m}$ lower. The amount of precipitation would be greater at the study site, but the timing and pattern should be similar.

At each location, 100 white locoweed plants were marked by placing a numbered tent peg in the ground next to them. Plants were selected in 2 age/size classes: young/small $<5$ stalks; older/large $>7$ stalks ( $n=50$ in each class). The design attempted to separate effects of clipping on young, newly established plants, vs older plants that had been established for several years. Within each size class, pairs of plants were selected that were as uniform as possible. One of each pair $(n=25)$ was randomly selected and clipped at ground level each subsequent year during the flower stage of growth. The unclipped member of each pair served as a control. Indices of vigor included: number of stalks (equivalent to tillers in a grass), number of flowering stems, longest leaf length, and tallest flowering head height. Pinnately compound leaves of white locoweed and flowering stalks originate from the crown. Measurements were taken from the crown at ground level to the tip of the longest leaf and flowering head. Mortality was noted each year. All 3 sites were fenced to prevent grazing from livestock. There was no evidence of wildlife grazing within the exclosures.

The study began in June 1995 at New Mexico and Colorado when the plants were selected, measured, and those designated for defoliation were clipped. Because of logistic problems, the study did not begin in Utah until July 1996. All of the large clipped plants were dead at New Mexico in 1998. Most of the other marked plants at New Mexico and Colorado were dead in 1999. There were sufficient numbers of plants remaining in both size/treatment classes to analyze at Utah in 2000.

Because of the different start times and differing number of years plants that survived at each location, vigor data were analyzed separately for each location. Vigor indices were analyzed by a mixed model in SAS in a repeated measures design using compound symmetry covariate structure to compare the main effects of plant size (2) and clipping treatment (2) over years, and their 2- and 3-way interactions. Individual plants were experimental units.

Plant mortality was analyzed by failuretime analysis (Fox 1993). Mortality over time was compared among locations and between age classes using the Cox Proportional Hazards model in a log-log model using SAS Proc Probit. To standardize time, years were placed on a numerical scale ( 1 to 4 ) rather than calender years. Survival curves were used to display mortality over time.

Below average precipitation (drought) occurred in New Mexico in 1997 and 1998, in Colorado in 1998 and 2000, and in Utah in 1999 and 2000. Correlations were made between annual mortality and seasonal precipitation (fall, winter, spring, summer) or total water year precipitation to determine if there was a relationship between reduced precipitation and mortality. Annual mortality was expressed as the $\%$ of the original 25 plants in each size/ clipping treatment class that died each year. The Palmer Drought Severity Index (Palmer 1965) for each of the respective regions was graphed to illustrate the severity of drought during the study period (Fig. 1).

Concentration of swainsonine, the toxic alkaloid in locoweeds, was measured in the leaves of clipped plants. Individual plant samples from each year were extracted using the general procedures of Molyneux et al. (1991). Detection and quantitation of swainsonine was accomplished using atmospheric pressure chemical ionization mass spectrometry (APCIMS) (Gardner et al. 2001). Swainsonine concentration between small and large plants was compared the first year by oneway analysis of variance (ANOVA) within locations. There was no difference between size classes $(\mathrm{P}>0.05)$. Thereafter, only large plants were extracted because many of the small plants did not have enough dry plant material for accurate quantification of the alkaloid (1 g). Swainsonine concentration within individual plants over years and among locations was compared by a repeated measures mixed model using compound symmetry covariate structure. Locations and years were main effects and plants within locations and years was the repeated factor. In a separate analysis, swainsonine in clipped plants was compared to 8 control plants (not the paired plant) that were randomly selected each year from the surrounding area to determine if clipping affected swainsonine concentration. Data were analyzed separately for each location by ANOVA comparing clipped and unclipped plants over years. $\mathrm{P}<0.05$ was considered significant.

\section{Results}

\section{Vigor Indices}

There was a significant year-by-size interaction $(\mathrm{P}<0.05)$ for most indices at all 3 locations, therefore the statistical model was reduced and the 2 size categories were analyzed separately for each location).

\section{Stalks/plant}

The initial number of stalks on large plants was 7.6 at Colorado, 16.2 at New 

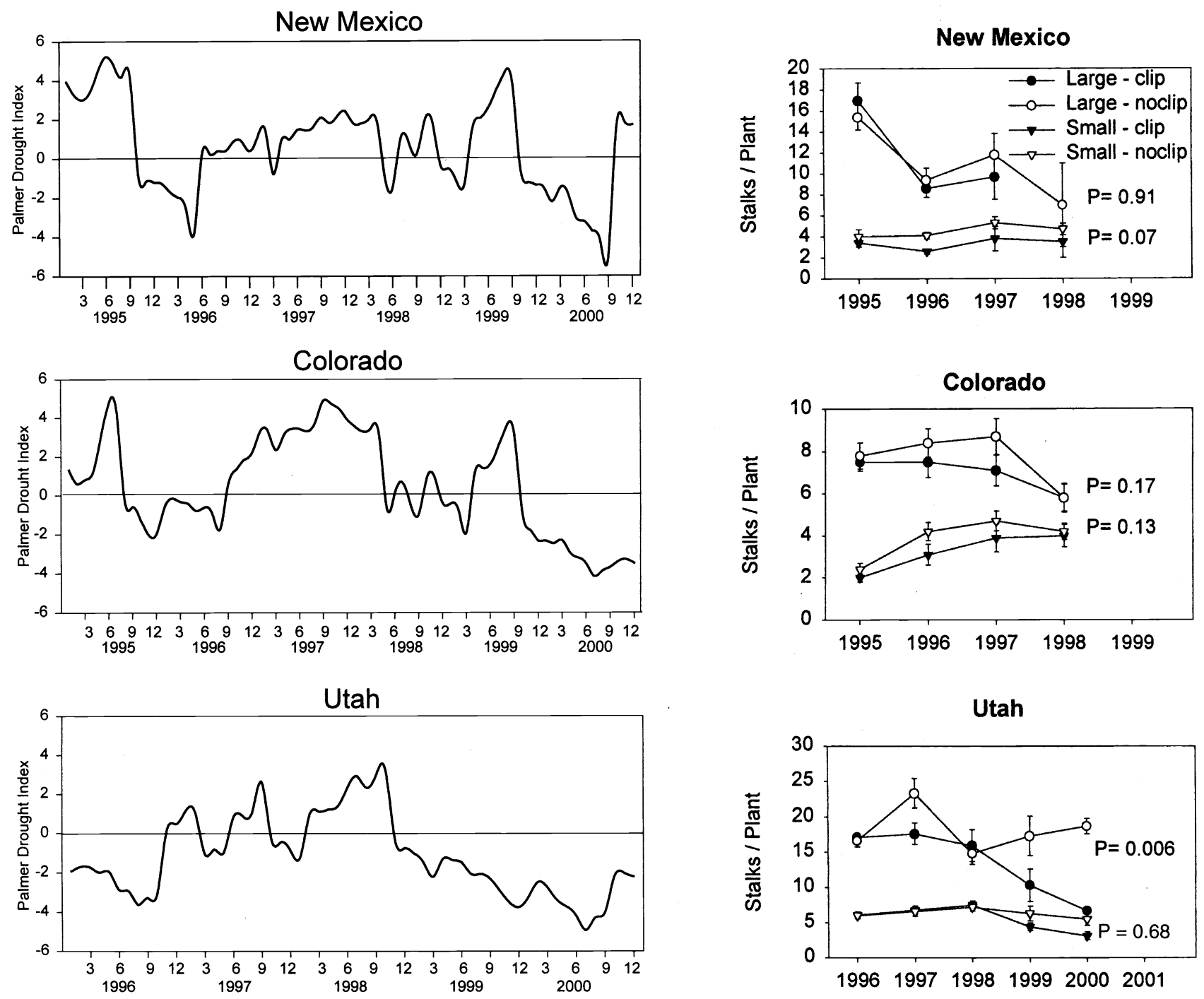

Fig. 1. Palmer Drought Severity Index for northeast New Mexico, north central Colorado, and north western Utah. Mild drought $\mathbf{- 1 . 0}$ to -2.0 ; moderate drought -2.0 to -3.0 ; severe drought -3.0 to -4.0 ; extreme drought $>\mathbf{- 4 . 0}$.

Fig. 2. The number of stalks/plant in large and small plants that were either clipped or not clipped at New Mexico, Colorado, and Utah over time. $P<0.05$ indicate differences between the clipped and non clipped plants in each size class.

Mexico, and 16.8 at Utah. The average number of stalks on small plants was 3.9 across locations, since the selection criteria for small plants was less than 5 stalks.

The main effect of clipping and the clip-by-year interaction was significant $(\mathrm{P}$ $<0.05$ ) only in large plants at Utah. The number of stalks on the large clipped plants at Utah declined from 16 to 7 over the study while the unclipped plants remained fairly constant (Fig. 2). The main effect of year was significant $(\mathrm{P}<$ 0.05 ) in both plant sizes and in most locations. At New Mexico, the number of stalks on large plants declined over time $(P=0.0001)$, but there was no difference between clipped and unclipped plants $(\mathrm{P}=$ 0.91). At Colorado and Utah, the number of stalks on small plants increased over years in both clipped and unclipped plants $(\mathrm{P}<0.0001)$, illustrating the growth or increase in number of stalks over time.

\section{Flowering Heads/Plant}

The initial number of flowering heads on large plants was 6.3 at Colorado, 20.2 at New Mexico, and 24.9 at Utah. The number of heads on small plants was 1.1, 0 , and 5.1 at the respective locations.

The number of flowering heads is a more sensitive measure of plant vigor than the number of tillers (stalks in this study) or leaf length (Mueggler 1972). The main effect of clipping tended to be significant $(P<0.10)$ in all sizes and locations except large plants at New Mexico, verifying that the clipping treatment reduced the number of flowering heads. The clip-by-year interaction was significant $(\mathrm{P}<0.05)$ for large plants at Colorado and Utah, and small plants at Utah. At Colorado, the number of heads on large clipped plants declined from 7 at the beginning of the study to 2 in 1996 , then increased to the level of the unclipped plants by 1998 (Fig. 3). At Utah, the number of heads of large clipped plants declined from 24 to 5 , and remained low for the remainder of the study. 

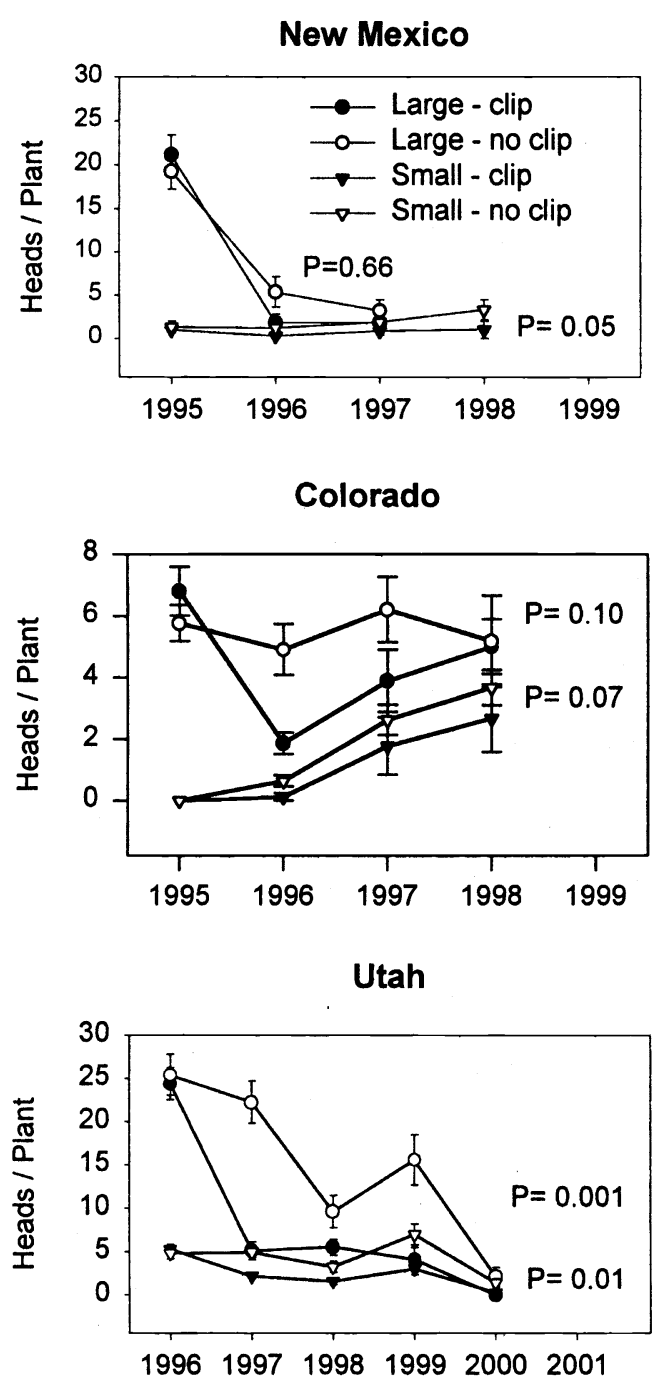
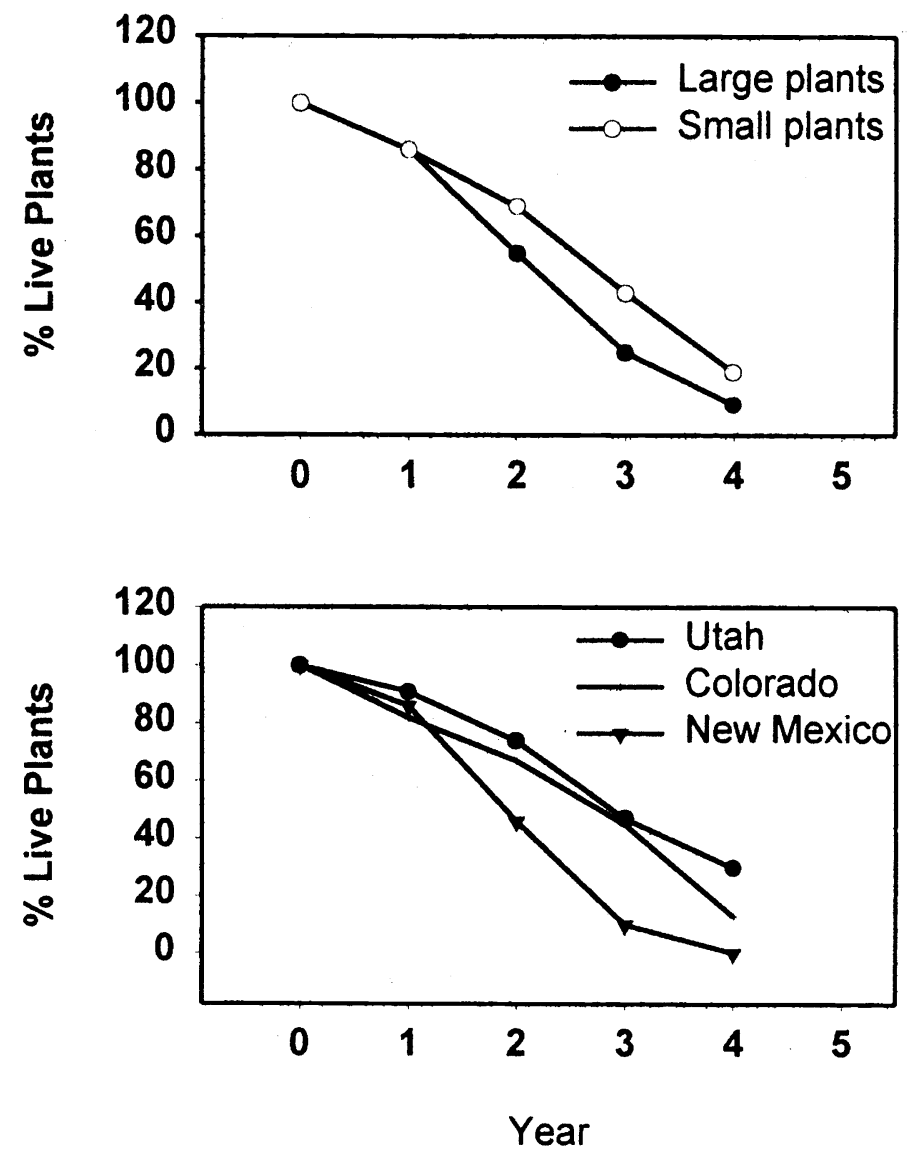

Fig. 3. The number of flower heads/plant in large and small plants that were either clipped or not clipped at New Mexico, Colorado and Utah over time. $P<0.05$ indicate differences between the clipped and non clipped plants in each size class.
Fig. 4. Locoweed mortality in large and small plants, and at 3 locations: New Mexico, Colorado and Utah.
Unclipped large plants declined gradually over the length of the study. The number of heads on small clipped plants at Utah declined in 1997 and 1998, and the number of heads in unclipped plants declined in 2000.

There was a strong year effect $(\mathrm{P}<$ 0.002 ) for both size plants and all locations. The number of heads in both clipped and unclipped large plants at New Mexico declined from 20 in 1995 to 5 in 1996. The number of heads of both clipped and unclipped small plants at Colorado increased over time.

There were some differences $(\mathrm{P}<0.05)$ in leaf length and head height at some locations, but they were slight and probably not large enough to influence the survival of the plants. Leaf length of large plants averaged $15 \mathrm{~cm}$, and was $11.4 \mathrm{~cm}$ for small plants; flowering head height averaged $19.6 \mathrm{~cm}$ over plant sizes and locations.

\section{Locoweed Mortality}

Clipping had no effect on mortality of locoweed plants at any of the locations ( $P$ $=0.93$ ). However, mortality over time was greater on large plants than on small plants $(\mathrm{P}=0.004)$ (Fig. 4). Mortality rate was greater at New Mexico $(\mathrm{P}<0.01)$; over
$50 \%$ of locoweed plants died following the winter and spring drought in 1996, and additional mortality occurred during the moderate droughts during the spring in 1998 and 1999 (Fig. 1). At Colorado, 84\% of small plants and $90 \%$ of large plants were dead after 4 years (Fig. 4), and the remaining plants died during the severe drought in 2000 (Fig. 1). Survival rate at Utah was higher $(\mathrm{P}<0.02)$ with $30 \%$ of the plants remaining after 4 years (Fig. 4). Although the mortality rate was not as great at Utah, the vigor measurements responded to the severe drought throughout 1999 and 2000 at Utah (Fig. 1).

Mortality was negatively correlated with 
Table 1. Swainsonine concentration in the same white locoweed plants clipped annually at New Mexico, Colorado and Utah $( \pm$ standard error of the mean).

\begin{tabular}{|c|c|c|c|c|c|c|c|}
\hline Location & 1995 & 1996 & 1997 & 1998 & 1999 & Mean & $\begin{array}{l}\text { Year } \\
\text { Diff. }\end{array}$ \\
\hline & $-\cdots$ & 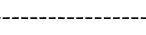 & ----- & Whiti) & 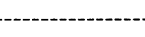 & ------ & -.---- \\
\hline NM & $0.11 \pm 0.01$ & $0.11 \pm 0.02$ & $0.07^{\circ} \pm 0.01$ & & & 0.097 & 0.07 \\
\hline $\mathrm{CO}$ & $0.04 \pm 0.01$ & $0.09 \pm 0.02$ & $0.06 \pm 0.02$ & $0.09 \pm 0.03$ & & 0.070 & 0.06 \\
\hline UT & & $0.07 \pm 0.01$ & $0.04 \pm 0.01$ & $0.03 \pm 0.01$ & $0.05 \pm 0.01$ & 0.048 & 0.05 \\
\hline
\end{tabular}

${ }^{\mathrm{l}}$ Mean difference within the same plant between years.

total water year precipitation at New Mexico ( $r=-0.84, p=0.008)$ and Utah $(\mathrm{r}=-0.75, \mathrm{p}=0.08)$. Correlation of locoweed mortality with summer precipitation at Colorado was not significant $(\mathrm{r}=$ $-0.42, \mathrm{P}=0.29$ ). However, the correlations were not totally accurate. High mortality in earlier years left few of the original marked plants in the experimental population, thus the mortality rate declined in the last year or 2. This reduced the strength of the correlations and underestimates the full impact of drought.

\section{Swainsonine}

Clipping had no effect on subsequent swainsonine concentration in locoweed plants $(\mathrm{P}=0.62)$. This is contrary to the Plant Defense Theory which suggests defoliation stimulates secondary defense compounds in some plants (Tallamy and Raupp 1991). There was also no difference in swainsonine concentration between large and small plants $(\mathrm{P}>0.05)$. There were differences among years $(\mathrm{P}<$ 0.07 ), but no recognizable trends (Table 1). There were differences among locations $(P=0.0001)$ with New Mexico having the highest concentration of swainsonine $(0.097 \%$ of dry wt), and Utah the lowest $(0.048 \%)$. Swainsonine concentration in a plant was not the same each year. Variability within the same plant over years was greater than the difference between locations (Table1).

\section{Discussion}

Clipping white locoweed in the flower stage for up to 4 successive years had only minor effects on vigor of the plants and did not affect mortality or swainsonine concentration. In tall larkspur (Delphinium barbeyi Huth), clipping at the bud elongation stage greatly reduced vigor and alkaloid pools for 2 subsequent years (Ralphs and Gardner 2001). Clipping other mountain forbs during the flowering stage was most detrimental to subsequent vigor (reviewed by Laycock 1975). Extensive research on rangeland grasses showed that clipping during anthesis was much more damaging than clipping during vegetative growth (reviewed by Caldwell 1984). Defoliation reduces photosynthetic capacity and root mass and retards the plants ability to extract water and nutrients from the soil. Neighboring plants use these resources, further reducing their availability. Thus, competition is the indirect factor causing reduction in subsequent vigor of clipped plants (Mueggler 1972). However, white locoweed has a deep tap root that extends below the rooting zone of grasses, and thus may not be subjected to direct competition for soil moisture. White locoweed does not appear to be adversely affected by annual defoliation in the flower stage or from competition from grasses.

Precipitation patterns apparently influenced white locoweed populations. Mortality occurred during the mild to severe drought periods at each of the locations. We found significant negative correlations between locoweed mortality and precipitation at New Mexico and Utah and weaker correlations with summer precipitation at Colorado. Our methodology of calculating mortality on marked plants without replacement may have limited the strength of the correlations. Furthermore, mortality of individual plants is determined by micro environmental conditions, which are difficult to estimate by seasonal weather measurements taken some distance form the study site.

Although white locoweed appears to be more persistent and longer-lived than many of the Astragalus locoweeds, our study showed that its populations still cycle. Marsh (1909) also observed that white locoweed was abundant in wet years, but nearly disappeared in dry years. Many of the semi-desert Astragalus locoweeds experience extreme population cycles that are driven by precipitation patterns (Welsh 1989). They germinate following autumn rains, remain green over winter, flower in spring, and may continue to grow for 1 or 2 years until the next drought occurs and the population dies back (A. lentiginosus, Barnes 1913; A. lentiginosus var. wahweapensis, Ralphs and Bagley 1988; A. pubentissimus, James et al. 1968).

Other factors besides drought may affect locoweed populations. The root-boring weevil Cleonidius trivittatus (Coleoptera: Curculionidae) prefer woolly locoweed (Astragalus mollissimus Torr.) and will kill the plant when 2 or more larvae occupy its root (Pomerinke et al. 1995). This insect and drought are major contributors to the crash of woolly locoweed populations. The insect is found to a lesser extent in white locoweed, but its influence on vigor and mortality is not known.

\section{Conclusions}

Clipping for 4 years did not consistently reduce vigor or increase mortality of white locoweed plants. Therefore, intensive grazing pressure, that would force consumption of white locoweed, would not likely reduce its population in the short term. There was a die-off of locoweed plants at all 3 locations that was associated with drought. The larger, and presumably older plants, had a slightly higher mortality rate, but a majority of small plants also died over the study. Clipping had no effect on subsequent toxicity of white locoweed.

\section{Literature Cited}

Barnes, W.C. 1913. Western grazing grounds and forest ranges. The Breeder's Gazette, Chicago. $390 \mathrm{pp}$.

Caldwell, M. M. 1984. Plant requirements for prudent grazing. pp. 117-152, in: Developing Strategies for Rangeland Management. Westview Press, Bolder Colo.

Fox, G.A. 1993. Failure-time analysis: emergence, flowering, survivorship, and other waiting times. pp. 253-289, In: S.M. Scheiner and J. Gurevitch (Eds) Design and Analysis of Ecological Experiments. Chapman \& Hall, New York. 
Gardner, D.R., R.J. Molyneux, and M.H. Ralphs. 2001. Analysis of swainsonine in locoweeds (Oxytropis spp.) Extraction methods and detection using liquid chromatography and tandem mass spectrometry. J. Agr. Food Chem. (in press).

James, L.F., K.L. Bennett, K.G. Parker, R.F. Keeler, W. Binns, and B. Lindsay. 1968. Loco plant poisoning in sheep. J. Range Manage. 21:360-365.

Laycock, W.A. 1975. Alkaloid content of duncecap larkspur after two years of clipping. J. Range Manage. 28:157-259.

Marsh, C.D. 1909. The locoweed disease of the plains. USDA Anim. Ind. Bull. 112.

Molyneux, R.J., L.F. James, K.E. Panter, and M.H. Ralphs. 1991. Analysis and distribution of swainsonine and related polyhydroxy indolizidine alkaloids by thin layer chromatography. Phytochem. Analys. 2:125-129.

Mueggler, W.F. 1972. Influence of competition on the response of bluebunch wheatgrass to clipping. J. Range Manage. 25:88-92.
Palmer, W.C. 1965. Meteorological Drought Res. Pap. No 45. U.S. Weather Bureau, NOAA Library and Info., Washington D.C. $58 \mathrm{pp}$.

Payne, G.F. 1957. Ecology and life history of the poisonous plant, white locoweed (Oxytropis sericea Nutt.). PhD Diss. Texas A\&M Univ., College Station, Tex.

Pfister, J.A., B.L. Stegelmeier, C.D. Cheney, L.F. James, and R.J. Molyneux. 1996. Operant analysis of chronic locoweed intoxication in sheep. J. Anim. Sci. 74:2622-2632.

Pomerinke, M.A., D.C. Thompson and D.L. Clason. 1995. Bionomics of Cleonidius trivittatus (Coleoptera: Curculionidae): native biological control of purple locoweed. Envir. Entom. 24:1697-1702.

Ralphs, M.H. and V.L. Bagley. 1988 Population cycles of Wahweap milkvetch on the Henry Mountains and seed reserve in the soil. Great Basin Natur. 48:541-547.
Ralphs, M.H. and E.H. Cronin. 1987. Locoweed seed in soil: density, longevity, germination and viability. Weed Sii. 35:792-795.

Ralphs, M.H. and D.R. Gardner. 2001. Influence of defoliation on toxic alkaloid concentration and alkaloid pools in tall larkspur. J. Chem. Ecol. (In press).

Tallamy, D.W. and M.J. Raupp. 1991. Phytochemical Induction by Herbivores. John Wiley \& Sons, New York.

Welsh, S.L. 1989. Astragalus L. and Oxytropis DC.: definitions, distributions, and ecological parameters. pp. 3-13, In: L.F. James, A.D. Elbein, R.J. Molyneux, C.D. Warren (eds.), Swainsonine and Related Glycosidase Inhibitors. Iowa State Univ. Press. Ames Ida. 


\title{
Long-term impacts of livestock grazing on Chihuahuan Desert rangelands
}

\author{
JOSEPH M. NAVARRO, DEE GALT, JERRY HOLECHEK, JIM MCCORMICK, AND FRANCISCO MOLINAR
}

Joseph Navarro is a Rangeland Management Specialist with the BLM in the Roswell Field Office 2909 W. 2nd St. Roswell, N.M. 88201 and a Graduate Research Assistant, Department of Animal and Range Sciences, New Mexico State University; Dee Galt is a private range consultant, Las Cruces, NM 88005; Jerry Holechek is a range science professor, Dept. of Animal and Range Sciences, New Mexico State University, Las Cruces, NM 88003; Jim McCormick is assistant field manager, Las Cruces Field Office, USDI, Bureau of Land Management, Las Cruces, NM 88005; and Francisco Molinar is a range animal ecology professor, School of Veterinary Medicine and Animal Science, Autonomous University of Juarez, Chihuahua, Mexico.

Abstract

Rangeland ecological condition was monitored over a 48 year period on 41 sites on Bureau of Land Management rangelands scattered across 6 counties in southwestern New Mexico. All sites were grazed by livestock during the study period. Sampling occurred in 1952, 1962, 1982, 1992, 1997, 1998, and 1999. A modified Parker 3 step method in conjunction with Dyksterhuis quantitative climax procedures were used to determine rangeland ecological condition. At the end of the 48 year study period (1952-1999), the average rangeland ecological condition score across study sites was the same $(P>0.05)$ as the beginning of the study (39\% versus $41 \%$ remaining climax vegetation, respectively). Major changes $(P>0.05)$ in rangeland condition occurred within the study period due to annual fluctuations in precipitation. Ecological condition scores increased in the 1980s and early 1990s due to above average precipitation. However, drought in the early to mid 1950's and again in the mid to late 1990's caused rangeland condition scores to decline. At the end of the study (1997-1999), 38\% of the sites were in late seral ecological condition, compared to an average of $25 \%$ in the 1952 to 1982 period. The amount of rangeland in late seral ecological condition increased while the amount of rangeland in mid seral and early seral condition decreased in the 1990s compared to the 1952-1962 period. The average percent cover of black grama (Bouteloua eriopoda Torr.) and tobosa (Hilaria mutica Buckley), the primary forage grasses in the Chihuahuan Desert, were the same $(P>$ 0.05 ) in 1952 and 1999 . Over the 48 year study period, the average cover of shrubs including honey mesquite (Prosopis glandulosa Torr.) showed no change $(P>0.05)$. However major increases in honey mesquite basal cover occurred on 1 site and creosotebush (Larria tridentata [Pursh] Nutt.) increased on another. Grazing intensity was evaluated during the last 3 years of study $(1997,1998,1999)$. Overall grazing use of forage across sites and years averaged $34 \%$ or conservative. Our research shows controlled livestock grazing is sustainable on Chihuahuan Desert rangelands receiving from $26-35 \mathrm{~cm}$ annual precipitation.

Key Words: Rangeland condition, succession, drought, grazing management, plant ecology

This project is \#14226910A970011, Monitoring Range Ecological Condition \& Trend Studies in the Northern Chihuahuan Desert Grasslands located in Southwestern New Mexico. Funding for this research was provided by the USDIBureau of Land Management and the New Mexico Agricultural Experiment Station.

Manuscript accepted 13 Sept. 2001

\section{Resúmen}

La condición ecológica de los pastizales del desierto chihuahuense se determinó en un estudio que abarcó 48 años y que se llevó a cabo en 41 sitios dentro de 6 condados del suroeste de Nuevo México. El estudio se realizó en terrenos administrados por la Agencia para el manejo de Tierras de los Estados Unidos. Los sitios estuvieron bajo pastoreo durante todos los años de duración del trabajo. Los muestreos se realizaron en 1952, 1962, 1982, 1992, 1997, 1998, y 1999. Se utilizó una modificación del sistema de 3 pasos de Parker y los procedimientos de Dyksterhuis para cuantificar el clímax. La finalidad fué determinar la condición ecológica de los pastizales. Al final de los 48 años del estudio (1952- 1999) se determinó que el promedio de la condición ecológica, al considerar todos los sitios, fue la misma $(P>0.05)$ que la existente al inicio de los trabajos en $1952(39 \%$ contra $41 \%$ del remanente de la vegetación del climax, respectivamente). Los cambios mas notorios en la condición ecológica durante los años del estudio $(P>0.05)$ se debieron a las fluctuaciones de la precipitación pluvial. Los rangos de la condición ecológica aumentaron en la década de los años ochenta y al inicio de los noventa debido al incremento de la precipitación. Sin embargo, la sequía al inicio y durante la primera mitad de los años cincuenta y nuevamente durante la segunda mitad y hasta el fin de los noventa, provocó que disminuyeran los porcentajes de la condición ecológica. En la parte final del trabajo (1997-1999), el $\mathbf{3 8 \%}$ de los sitios se encontraron bajo condición ecológica de buena a excelente, en comparación con el $25 \%$ bajo esas condiciones durante el período de 1952 a 1962. Al comparar los resultados de los años noventa con el período de 1952 a 1982, la cantidad de pastizales en estado ecológico bueno a excelente se incrementó y la cantidad en estado pobre a regular disminuyó. Los promedios de cobertura de los zacates mas representativos del desierto chihuahuense como navajita negro (Bouteloa eripoda Torr.) y Toboso (Hilaria mutica Buckley) fueron los mismos (P > 0.05) en 1952 y en 1999. Durante los 48 años del estudio, el promedio de cobertura de plantas leñosas como el mezquite (Prosopis glandulosa Torr.) no mostró cambios mayores (P > 0.05). Sin embargo, se detectaron incrementos importantes en la cobertura basal de Prosopis en uno de los sitios y de la gobernadora (Larrea tridentata [Pursh] Nutt.) en otro. Por otra parte, se evaluó la intensidad de pastoreo durante los últimos 3 años (1997, 1998, 1999). La utilización promedio del forraje al contabilizar todos los sitios y los años fue conservadora o del $34 \%$ del total. Nuestra investigación indica que el pastoreo controlado es viable en pastizales del desierto chihuahuense, aunque solo se reciban niveles de precipitación pluvial de 260 a $350 \mathrm{~mm}$ anuales. 
Published quantitative information is lacking on the general trend in ecological condition for different types of public rangelands in New Mexico and other western states. Information is available on range condition and trend for many individual public grazing allotments throughout the western states. Various government reports have indicated range condition on public lands is improving but these reports are somewhat vague and subjective regarding how range condition was measured and classified (United States Department of Interior 1999). Studies are needed that quantitatively characterize long-term changes in rangeland vegetation in different range biomes in response to climatic conditions and livestock grazing management. This information is also needed because of increased social pressure to remove livestock from public rangelands and emphasis on non-consumptive rangeland uses (Wuerthner 1990, Donahue 1999).

Recent studies in the Chihuahuan Desert of southern New Mexico have shown that controlled livestock grazing can be biologically sustainable, economically cost effective, and compatible with most wildlife species (Holechek et al. 1994, Nelson et al. 1997, Winder et al. 2000). However evaluations are needed over broad areas to determine the effects of livestock grazing as it has actually occurred. There is considerable concern among many conservation groups that ranchers may not be using sustainable grazing practices (Wuerthner 1990).

The 1950s drought had great impact on Chihuahuan Desert rangelands (Buffington and Herbel 1965). However detailed scientific evaluation of the impacts of this event on Chihuahuan Desert vegetation has been reported only from the USDA Jornada Experimental Range in southcentral New Mexico (Buffington and Herbel 1965, Herbel et al. 1972, Herbel and Gibbens 1996). Drought and post drought vegetation responses on the Jornada Experimental Range however may not be completely representative of the Chihuahuan Desert in southern New Mexico.

The objective of our study was to evaluate long term (48 years) trend in vegetation composition using 41 locatable Parker sites in the Chihuahuan Desert of southwestern New Mexico. Complete data is available for 7 years of sampling (1952, $1962,1982,1992,1997,1998,1999)$ on 22 of these sites. A secondary objective was to evaluate grazing intensity on the study sites in late spring of 1998, 1999, and 2000 using procedures of Holechek and Galt (2000).

\section{Methods}

\section{Study Area}

In 1952 the Bureau of Land Management initiated a study to examine long term trend in range vegetation in the Chihuahuan Desert of southwestern New Mexico. This study involved use of the Parker 3 step method (Parker 1951). Parker transects on the various sites were evaluated in 1952, 1962, 1982, 1992, 1997, 1998, and 1999.

The majority of the study area lies within the northern end of the Chihuahuan Desert $\left(106^{\circ} 52^{\prime} 30^{\prime \prime} \mathrm{W}, 32^{\circ} 32^{\prime} 30 \mathrm{~N}\right)$. The study area is bounded by Texas and Mexico to the south, Arizona to the west, and is traversed by the Rio Grande on the eastern side. This region is administered by the USDI-Bureau of Land Management Mimbres and Caballo Resource Areas in the Las Cruces District. The Mimbres Resource Area includes Hidalgo, Grant, Luna, and Dona Ana counties. The Caballo Resource Area includes Otero and Sierra counties. There are 2.7 million ha of BLM administered public land intermingled with 5.3 million ha of private, State trust, Native American, and other Federal lands in this 6 county area.

The area is characterized by an arid to semiarid continental climate, with mild winters and hot summers. Most of the study area receives from $26-35 \mathrm{~cm}$ annual precipitation. Annual fluctuations range from a low of $5 \mathrm{~cm}$ to a high of over 50 $\mathrm{cm}$. Over half of the annual precipitation arrives as rainfall during July, August, and September. The average frost free season exceeds 200 days and extends from April to November. The average annual temperature in the area is about $20^{\circ} \mathrm{C}$. During the summer months, daytime temperatures may exceed $38^{\circ} \mathrm{C}$. Through the year, a daily range of $17^{\circ} \mathrm{C}$ or more is common. Both the rainfall distribution and temperature regime favor warm season perennial plants.

Typical landform includes rugged and steep fault-block mountain ranges, broad basins, and volcanic uplands. Elevations on BLM-administered public land range from a low of approximately $1,067 \mathrm{~m}$ in the southern Mesilla Valley to a high of over $2,438 \mathrm{~m}$ in some of the mountain ranges. Average elevation is about 1,372 $\mathrm{m}$. Our study sites are primarily in the broad basins.

The vegetation varies greatly in its diversity and herbage yields due to differences in elevation, climate, soils, and topography. Plant communities include desert grasslands, mixed desert shrublands, desert shrublands, mountain brush, and pinon-juniper/oak woodland. Our study sites were confined primarily to the desert grasslands with a few desert shrubland sites. The 7 major range sites based on USDA-Natural Resources Conservation Service guides are gravelly, igneous hills, sandy, loamy, gravelly loam, malpais, and clayey.

\section{Sampling Procedures}

Forty-one different study sites were used in this analysis. Generally the goals in site selection were to select accessible flat grassland areas with uniform soils in medium size to large pastures $1.4 \mathrm{~km}$ from water. Site selection was based on ease of access, distance from water, soil type, vegetation type, size of pasture, and terrain. Ecotones where soil types and vegetation were in transition were avoided. All study sites were located on uniform soils, flat terrain and in uniform, discreet plant communities. One site had 1 transect, 26 sites had 2 transects, 10 sites had 3 transects and 4 sites had 5 transects. All sites were within $1.2 \mathrm{~km}$ to $1.6 \mathrm{~km}$ of permanent water, and were grazed during the period of the study. The 41 sites we studied are well scattered over 6 counties in southwestern New Mexico.

A modification of the Parker 3 step method was used to evaluate trends in vegetation cover on each site (Parker 1951). Permanent 30.5-m line transects were accurately located from existing steel rebar. Readings were taken and recorded at $30.5 \mathrm{~cm}$ intervals using a loop $1.91-\mathrm{cm}$ in diameter along a tape stretched between the 2 permanent rebar stakes. Data recorded along the transect included presence of all herbaceous plants and shrubs rooted within the loop. There were no recordings of multiple plants within the loop. Evaluations were conducted during the dormant period of the year (late fall through early spring). Transect data were collected for the years of 1952-54, 1962-64, 1982, 1992, 1997, 1998, and 1999. In all years of study, data were collected by professionals with range science training. Dr. Dee Galt, a private range consultant with 30 years experience in the USDA-Natural Resources Conservation Service, supervised all data collection in the 1992 to 1999 period.

Plant cover in our study is more of an 
index than an absolute value. Loop sampling tends to overestimate cover for small plants (Hutchings and Holmgren 1959). However, as a cover index, loop sampling is reliable for detecting vegetation changes over time (Smith 1962).

Range ecological condition scores were calculated from current USDA Natural Resources Conservation Service New Mexico range site guides using the Dyksterhuis (1949) procedure. Cover was used instead of biomass in calculating scores. Cover and biomass indices gave similar ecological condition scores across several sites on the Chihuahuan Desert Rangeland Research Center in southcentral New Mexico (Molinar 1999).

During late spring (May, June) in the last 3 years of study, grazing intensity was evaluated on all study sites using procedures of Holechek and Galt (2000). This approach involves assessment of forage stubble heights, remaining seed stalks, and percentage of plants grazed.

Comparisons among years for ecological condition scores and plant cover were analyzed by analysis of variance using a completely randomized design with study sites as replicates. The least significant difference mean separation procedure was used to compare means in time if analysis of variance indicated a significant difference (Steel and Torrie 1980).

\section{Results and Discussion}

Average rangeland ecological condition score was not different $(\mathrm{P}>0.05)$ between 1952 and $1999(n=22)$ (Table 1). For the 22 sites supporting complete data sets, the 1950 s drought caused a drop in range condition, but steady improvement occurred from 1962 to 1992.

Possibly the most reliable assessment of change in ecological condition through time on our study areas is the comparison of the average of the first 3 years sampled in our study $(1952,1962,1982)$ with the last 3 years $(1997,1998,1999)$ across the 22 sites with complete data (Table 1). On this basis the condition score averaged $33.7 \%$ for the 1952-1982 period compared to $37.0 \%$ for the 1997-1999 period, with no significant $(\mathrm{P}=0.36)$ differences. Therefore, we conclude that no change has occurred in rangeland ecological condition between early years and the final years of our study.

Shifting climatic conditions in southwestern New Mexico explain the major fluctuations in rangeland ecological condition from 1952 to 1999 (Table 2). The 1950s were characterized by extreme drought receiving $73 \%$ of the 100 year average (National Oceanic and Atmospheric Administration 1999). In contrast, precipitation in the 1980 s was $12 \%$ above the 100 year average.

Climatic conditions in southwestern New Mexico in the 1992 to 1999 period were near normal (Table 2). Four years were wet $(1992,1993,1997,1999)$, one year was dry (1995), and 3 years were near average $(1994,1996,1998)$ (National Oceanic and Atmospheric Administration 1999). Above average growing season precipitation (May through September) occurred in 1992, 1996, 1997, and 1999.
In 1994 and 1995 growing season precipitation was well below average. Annual precipitation averaged $29.74 \mathrm{~cm}$ for the 1992-1999 period compared to the long term average of $30.07 \mathrm{~cm}$. From a historical standpoint, the 1980s and 1990s were the wettest decades in New Mexico during the past 100 years while the 1950 s were the driest.

Rangeland ecological condition scores for individual sites showed considerable fluctuation in the 1997-1999 period (Table 1). We attribute this to both sampling disparities and climatic variability. Because fewer plants were encountered along the transects in low ecological con-

Table 1. Ecological condition scores (USDA-National Resources Conservation Service method) on 41 sites on Bureau of Land Management rangelands in the Chihuahuan Desert of New Mexico over a 48 year period (1952-1999).

\begin{tabular}{|c|c|c|c|c|c|c|c|c|}
\hline Range site & County & 19521 & 1962 & 1982 & 1992 & 1997 & 1998 & 1999 \\
\hline & $\cdots$ & & & $-(\%$ & - & -- & - & -5 \\
\hline Clayey & Grant & 47 & 62 & 52 & 67 & 70 & 70 & 74 \\
\hline Loamy & Luna & 24 & 9 & 21 & 32 & 15 & 23 & 26 \\
\hline Sandy & Dona Ana & 14 & 13 & 19 & 23 & 15 & 17 & 27 \\
\hline Shallow Sandy & Dona Ana & 26 & 44 & 14 & 48 & 43 & 6 & 16 \\
\hline Clayey & Luna & 56 & 43 & 43 & 56 & 38 & 26 & 50 \\
\hline Clayey & Grant & 65 & 26 & 46 & 50 & 51 & 51 & 43 \\
\hline Gravelly & Sierra & 35 & 33 & 51 & 47 & 48 & 49 & 53 \\
\hline Clayey & Hidalgo & 38 & 8 & 22 & 25 & 19 & 18 & 16 \\
\hline Clayey & Hidalgo & 57 & 20 & 49 & 79 & 55 & 46 & 53 \\
\hline Clayey & Hidalgo & 44 & 46 & 40 & 43 & 33 & 32 & 52 \\
\hline Loamy & Hidalgo & 48 & 44 & 40 & 47 & 35 & 45 & 50 \\
\hline Loamy & Hidalgo & 49 & 21 & 21 & 36 & 23 & 34 & 31 \\
\hline Sandy & Hidalgo & 30 & 12 & 22 & 21 & 28 & 32 & 31 \\
\hline Sandy & Hidalgo & 11 & 8 & 8 & 14 & 16 & 8 & 8 \\
\hline Clayey & Dona Ana & 51 & 46 & 43 & 41 & 40 & 45 & 43 \\
\hline Draw & Luna & 63 & 36 & 66 & 69 & 66 & 60 & 63 \\
\hline Loamy & Grant & 15 & 13 & 16 & 16 & 17 & 26 & 31 \\
\hline Sandy & Luna & 30 & 35 & 37 & 41 & 35 & 43 & 56 \\
\hline Clayey & Luna & 56 & 28 & 47 & 49 & 43 & 44 & 43 \\
\hline Hills & Hidalgo & 32 & 18 & 10 & 27 & 26 & 20 & 43 \\
\hline Loamy & Hidalgo & 42 & 31 & 46 & 47 & 41 & 50 & 61 \\
\hline Gravelly & Dona Ana & 32 & 23 & 23 & 20 & 20 & 15 & 20 \\
\hline Gravelly & Luna & 25 & 48 & --- & 66 & 73 & 60 & 60 \\
\hline Shallow Sandy & Sierra & --- & 37 & 73 & 62 & 61 & 62 & 57 \\
\hline Shallow Sandy & Otero & --- & 68 & --- & 80 & 70 & 65 & 84 \\
\hline Loamy & Sierra & --- & 21 & 55 & 58 & 63 & 63 & 71 \\
\hline Breaks & Sierra & --- & 46 & 57 & 48 & 57 & 46 & 53 \\
\hline Hills & Sierra & --- & 46 & 58 & 51 & 52 & 42 & 59 \\
\hline Gravelly & Sierra & --- & 55 & 50 & 54 & 57 & 55 & 55 \\
\hline Clayey & Hidalgo & --- & 20 & 37 & 55 & 58 & 55 & 53 \\
\hline Hills & Hidalgo & --- & 45 & 43 & 53 & 48 & 51 & 51 \\
\hline Gravelly & Luna & --- & 35 & 33 & 60 & 40 & 48 & 43 \\
\hline Hills & Hidalgo & --- & 41 & 50 & 49 & 48 & 45 & 51 \\
\hline Hills & Hidalgo & --- & 53 & 30 & 27 & 18 & 19 & 13 \\
\hline Gravelly & Luna & --- & 33 & 51 & 50 & 60 & 51 & 65 \\
\hline Shallow Sandy & Dona Ana & --- & 48 & 30 & 37 & 16 & 21 & 41 \\
\hline Gravelly & Sierra & --- & 34 & 42 & 44 & 38 & 34 & 56 \\
\hline Sandy & Sierra & --- & 39 & 43 & 50 & 45 & 28 & 44 \\
\hline Loamy & Otero & --- & 17 & 45 & 55 & 50 & 45 & 68 \\
\hline Shallow Sandy & Hidalgo & --- & 48 & --- & 53 & 34 & 37 & 59 \\
\hline Sandy & Dona Ana & -- & $-\cdots$ & --- & --- & --- & 58 & 65 \\
\hline $\begin{array}{l}\text { Average } \bar{x} \\
\text { (All sites) }\end{array}$ & & & $34^{\mathrm{c}}$ & $39^{b c}$ & $46^{\mathrm{ab}}$ & $42^{\mathrm{ab}}$ & $39^{b}$ & $47^{\mathrm{a}}$ \\
\hline $\begin{array}{l}\text { Average } \frac{}{x} \\
\text { (First } 22 \text { sites) }\end{array}$ & & $39^{\mathrm{ab}}$ & $28^{\mathrm{c}}$ & $33^{\mathrm{bc}}$ & $41^{\mathrm{a}}$ & $36^{\mathrm{ab}}$ & $34^{b}$ & $41^{\mathrm{a}}$ \\
\hline
\end{tabular}

a,b,c Means within rows with different superscripts differ at $\mathrm{P}<0.05$. 
Table 2. Annual precipitation (PPT-cm) for 10 year intervals in southwestern new Mexico for the 1950-1999 period (National Oceanic and Atmospheric Administration 1999). ${ }^{1}$

\begin{tabular}{lrcccccccc}
\hline \hline Year & PPT & Year & PPT & Year & PPT & Year & PPT & Year & PPT \\
\hline & $(\mathrm{cm})$ & & $(\mathrm{cm})$ & & $(\mathrm{cm})$ & & $(\mathrm{cm})$ & & $(\mathrm{cm})$ \\
1950 & 14.05 & 1960 & 25.30 & 1970 & 19.41 & 1980 & 23.80 & 1990 & 37.87 \\
1951 & 15.80 & 1961 & 28.04 & 1971 & 23.60 & 1981 & 30.86 & 1991 & 44.25 \\
1952 & 14.99 & 1962 & 31.72 & 1972 & 37.59 & 1982 & 26.83 & 1992 & 37.72 \\
1953 & 9.70 & 1963 & 23.88 & 1973 & 23.93 & 1983 & 35.53 & 1993 & 30.53 \\
1954 & 15.57 & 1964 & 21.36 & 1974 & 33.12 & 1984 & 42.95 & 1994 & 29.67 \\
1955 & 25.60 & 1965 & 28.80 & 1975 & 30.10 & 1985 & 40.28 & 1995 & 21.49 \\
1956 & 12.12 & 1966 & 24.66 & 1976 & 25.30 & 1986 & 44.37 & 1996 & 27.79 \\
1957 & 31.98 & 1967 & 28.93 & 1977 & 27.13 & 1987 & 30.76 & 1997 & 32.74 \\
1958 & 41.43 & 1968 & 27.56 & 1978 & 36.25 & 1988 & 36.47 & 1998 & 28.22 \\
1959 & 23.98 & 1969 & 26.64 & 1979 & 29.36 & 1989 & 22.33 & 1999 & 28.37 \\
$\frac{\mathrm{x}}{1953}$ & 20.52 & & 26.70 & & 28.58 & & 33.63 & & 31.88 \\
\hline
\end{tabular}

${ }^{1}$ Locations monitored include Afton, Alamogordo, Animas, Antelope Wells, Buckhorn, Cliff, Columbus, Deming, Glenwood, Hachita, Hillsboro, Jornada, Las Cruces, Lordsburg, Orogrande, Redrock, Truth or Consequences, White Sands, White Signal, and Whitewater.

dition sites, more annual variability occurred in vegetation composition. Some sites had major fluctuations in broom snakeweed (Gutierrizea sarothrae Pursh.) populations during 1997-1999 period. Broom snakeweed is a short lived, poisonous, perennial half shrub whose populations can fluctuate greatly from year to year with weather (Pieper and McDaniel 1989). Wet winters and springs promote broom snakeweed establishment.

Our data provide only limited insight into the various rangeland plant successional models (Holechek et al. 2001), because large time gaps occurred between some of the assessments on the sites. In addition, grazing management changes on the sites were not well documented across time. We do note that there was a tendency for sites in early seral stages to show improvement during the 1962-1999 period (Table 1). Nine of the 13 sites in an early seral stage improved to mid seral or late seral condition. This provides support for the theories of Dyksterhuis (1949) that some degraded rangelands can improve through natural plant succession under favorable climatic conditions and controlled livestock grazing.

Black grama (Bouteloua eriopoda Torr.), the primary decreaser forage in southern New Mexico, showed no difference $(\mathrm{P}>0.05)$ in basal cover between 1952 and $1999(\mathrm{n}=22)$ (Table 3). Tobosa (Hilaria mutica Buckley) and total perennial grass cover did not differ $(\mathrm{P}>0.05)$ between 1952 and $1999(\mathrm{n}=22)$. No increase in shrub basal cover $(\mathrm{P}>0.05)$ occurred over the 4 year period $(\mathrm{n}=22)$ (Table 3). Honey mesquite (Prosopis glandulosa Torr.) cover was the same (P > $0.05)$ in 1952 and $1999(n=22)$. However, 2 sites had major increases in shrub basal cover when the 1952-1962 period was compared to the 1997-1999 period. Honey mesquite was invading 1 site while creosotebush (Larrea tridentata [Pursh] Nutt.) was invading another.

Black grama and other perennial grasses had a sharp increase $(\mathrm{P}<0.05)$ in basal

\section{Table 3. Variation in mean basal cover (\%) of primary plant species found on 41 different sites on Bureau of Land Management rangelands in the Chihuahuan Desert of New Mexico over a 48 year period (1952-1999).}

\begin{tabular}{|c|c|c|c|c|c|c|c|}
\hline \multirow[b]{3}{*}{ Plant category } & \multicolumn{7}{|c|}{ First 22 sites } \\
\hline & \multicolumn{7}{|c|}{ Year } \\
\hline & $1952^{1}$ & 1962 & 1982 & 1992 & 1997 & 1998 & 1999 \\
\hline & \multicolumn{7}{|c|}{ 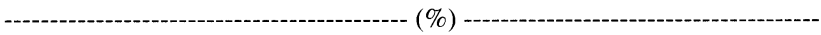 } \\
\hline Tobosa & $4.0^{\mathrm{a}}$ & $2.3^{\mathrm{a}}$ & $4.9^{\mathrm{a}}$ & $10.2^{\mathrm{a}}$ & $3.4^{\mathrm{a}}$ & $3.0^{\mathrm{a}}$ & $3.3^{\mathrm{a}}$ \\
\hline Black Grama & $1.5^{\mathrm{a}}$ & $1.1^{\mathrm{a}}$ & $1.6^{\mathrm{a}}$ & $4.7^{\mathrm{a}}$ & $1.2^{\mathrm{a}}$ & $1.4^{\mathrm{a}}$ & $1.5^{\mathrm{a}}$ \\
\hline Burrograss & 2.8 & 1.5 & 2.3 & 3.4 & 0.6 & 0.9 & 0.9 \\
\hline Aristida spp. & 0.2 & 0.0 & 0.0 & 1.5 & 0.2 & 0.3 & 0.2 \\
\hline Other perennial grasses & $3.4^{\mathrm{a}}$ & $2.3^{\mathrm{a}}$ & $3.3^{\mathrm{a}}$ & $6.2^{b}$ & $1.6^{\mathrm{a}}$ & $1.6^{\mathrm{a}}$ & $2.4^{\mathrm{a}}$ \\
\hline Annual grasses & 0.0 & 0.0 & 0.4 & 0.2 & Trace & 1.2 & 1.4 \\
\hline Total grasses & $11.9^{\mathrm{a}}$ & $7.2^{\mathrm{a}}$ & $12.5^{\mathrm{a}}$ & $26.2^{\mathrm{b}}$ & $7.2^{\mathrm{a}}$ & $8.4^{\mathrm{a}}$ & $9.7^{\mathrm{a}}$ \\
\hline Total forbs & $2.5^{\mathrm{a}}$ & $6.6^{\mathrm{a}}$ & $1.9^{\mathrm{a}}$ & $7.9^{\mathrm{b}}$ & $2.8^{\mathrm{a}}$ & $2.2^{\mathrm{a}}$ & $0.6^{\mathrm{a}}$ \\
\hline Honey mesquite & 0.2 & 0.1 & 0.3 & 0.6 & Trace & 0.0 & 0.2 \\
\hline Broom snakeweed & 0.4 & 0.4 & 1.7 & 2.0 & Trace & 0.2 & 0.2 \\
\hline Other shrubs & 0.3 & 0.1 & 0.8 & 1.2 & 0.1 & Trace & 0.1 \\
\hline Total shrubs & 0.9 & 0.6 & 2.8 & 3.8 & 0.2 & 0.3 & 0.5 \\
\hline \multirow[t]{3}{*}{ Total basal cover } & $15.3^{\mathrm{a}}$ & $14.4^{\mathrm{a}}$ & $17.2^{\mathrm{a}}$ & $37.9^{\mathrm{b}}$ & $10.2^{\mathrm{a}}$ & $10.9^{\mathrm{a}}$ & $10.8^{\mathrm{a}}$ \\
\hline & \multicolumn{7}{|c|}{ All 41 sites } \\
\hline & \multicolumn{7}{|c|}{ Year } \\
\hline Plant category & & 1962 & 1982 & 1992 & 1997 & 1998 & 1999 \\
\hline Tobosa & \multicolumn{7}{|c|}{ - } \\
\hline Black Grama & & $2.8^{\mathrm{a}}$ & $2.8^{\mathrm{a}}$ & $9.0^{\mathrm{b}}$ & $1.9^{\mathrm{a}}$ & $2.1^{\mathrm{a}}$ & $2.9^{\mathrm{a}}$ \\
\hline Burrograss & & 1.6 & 2.1 & 2.5 & 0.7 & 0.8 & 0.9 \\
\hline Aristida spp. & & Trace & 0.3 & 2.2 & 0.4 & 0.4 & 0.4 \\
\hline Other perennial grasses & & $2.8^{\mathrm{a}}$ & $2.6^{\mathrm{a}}$ & $6.9^{b}$ & $2.0^{\mathrm{a}}$ & $1.8^{\mathrm{a}}$ & $2.5^{\mathrm{a}}$ \\
\hline Annual grasses & & Trace & 0.2 & 0.1 & Trace & 0.7 & 0.9 \\
\hline Total grasses & & $8.9^{\mathrm{a}}$ & $11.4^{\mathrm{a}}$ & $27.6^{\mathrm{b}}$ & $7.1^{\mathrm{a}}$ & $7.7^{\mathrm{a}}$ & $9.7^{\mathrm{a}}$ \\
\hline Total forbs & & $4.6^{\mathrm{a}}$ & $2.5^{\mathrm{a}}$ & $5.2^{\mathrm{b}}$ & $1.8^{\mathrm{a}}$ & $1.6^{\mathrm{a}}$ & $0.6^{\mathrm{a}}$ \\
\hline Honey mesquite & & Trace & 0.3 & 0.3 & Trace & Trace & 0.2 \\
\hline Broom snakeweed & & 0.4 & 1.6 & 1.6 & Trace & 0.2 & 0.3 \\
\hline Other shrubs & & Trace & 1.2 & 1.3 & 0.3 & 0.4 & 0.7 \\
\hline Total shrubs & & 0.4 & 3.1 & 3.2 & 0.3 & 0.4 & 0.7 \\
\hline Total basal cover & & $13.9^{\mathrm{a}}$ & $17.0^{\mathrm{a}}$ & $36.0^{\mathrm{b}}$ & $9.2^{\mathrm{a}}$ & $9.7^{\mathrm{a}}$ & $11.0^{\mathrm{a}}$ \\
\hline
\end{tabular}

\footnotetext{
${ }^{\mathrm{ab}}$ Means within rows with different superscripts differ at $\mathrm{P}<0.05$.
} spacing of rainfall events. Storms that did occur generally were well distributed through July and August, and seldom involved more than $0.76 \mathrm{~cm}$ precipitation. This moisture was quickly lost to evapora-

cover during the 1982-1992 period, and then sharply declined $(\mathrm{P}<0.05)$ in the 1992-1999 period $(n=22)$ (Table 3). We speculate the dry summers in 1994 and 1995 were more damaging to perennial grasses than in other decades because the long run of wet years in the 1980s and 1990s may have reduced plant resistance to drought. Well above average precipitation in the 1990-1992 period elevated perennial grass basal cover above what plant root systems could support in normal years. Plant rooting depths and root to shoot ratios may have been altered by the exceptionally wet conditions. This could have altered the plant's ability to cope with the return to more normal precipitation conditions. The severity of consecutive summer droughts in 1994 and 1995 may have also been accentuated by the

\section{.}


Table 4. Percentages of study sites (41) in southwestern New Mexico classified as either severely grazed, heavily grazed, moderately grazed, conservatively grazed, lightly grazed or ungrazed by livestock in 1998, 1999, and 2000.

\begin{tabular}{|c|c|c|c|c|c|c|}
\hline \multirow[b]{2}{*}{ Year } & \multicolumn{5}{|c|}{ Grazing intensity } & \multirow[b]{2}{*}{ Ungrazed } \\
\hline & Severe & Heavy & Moderate & Conservative & Light & \\
\hline & & & & & & \\
\hline 1998 & 0 & 7 & 38 & 0 & 48 & 7 \\
\hline 1999 & 2 & 18 & 41 & 27 & 5 & 7 \\
\hline 2000 & 0 & 10 & 27 & 29 & 32 & 2 \\
\hline $\bar{x}$ & 1 & 12 & 35 & 19 & 28 & 5 \\
\hline
\end{tabular}

tion. Generally about $2.54 \mathrm{~cm}$ of rain, concentrated within a 1 week period, is needed to initiate growth of desert grasses such as black grama and tobosa (Canfield 1939). This did not occur in 1994 or 1995 in most parts of southwestern New Mexico. Research on the Chihuahuan Desert Rangeland Research Center north of Las Cruces indicated that forage production in 1994 and 1995 was only $18 \%$ of the 32 year average (Holechek et al. 2000).

Based on tree ring data, extended droughts lasting 5-12 years have occurred about every 50 to 60 years in the southwestern United States (Meko et al. 1995). The last extended drought occurred in the 1941 to 1956 period. Twelve of the 15 years had below average precipitation. Some climatologists believe the southwestern United States is again entering an extended dry period (Fleck 1998).

Grazing intensity across the 41 sites was considered to be conservative (34\% use of forage) (Table 4). Seven sites showed repeated heavy grazing during the 3 years grazing intensity was measured. Nineteen of the 41 study sites were lightly or conservatively stocked.

Our interviews with permittees using the study sites indicated ranchers are better informed on the benefits of conservative stocking than they were 8 years ago (1992). About 1 half of the ranchers interviewed were consciously attempting to implement conservative stocking on their grazing allotments.

Table 5. Percentages of Bureau of Land Management study sites (41) in southwestern New Mexico in different ecological condition categories in 1952, 1962, 1982, 1992, and 1999.

\begin{tabular}{lcccc}
\hline \hline Year & $\begin{array}{l}\text { Excellent } \\
\text { (climax) }\end{array}$ & $\begin{array}{c}\text { Good } \\
\text { (late seral) }\end{array}$ & $\begin{array}{c}\text { Fair } \\
\text { (mid seral) }\end{array}$ & $\begin{array}{c}\text { Poor } \\
\text { (early seral) }\end{array}$ \\
\hline $1952^{1}$ & 0 & 26 & 52 & 22 \\
1962 & 0 & 24 & 44 & 32 \\
1982 & 0 & 24 & 50 & 26 \\
1992 & 5 & 32 & 48 & 15 \\
1997 & 0 & 32 & 45 & 23 \\
1998 & 0 & 30 & 46 & 24 \\
1999 & 2 & 51 & 35 & 12 \\
\hline
\end{tabular}

Only 22 sites were evaluated in 1952

None of our study sites had any type of shrub control applied during the 48 year study period. Additional water development had occurred within several study pastures but not near our study sites. Data in New Mexico Agricultural Experiment Station reports indicated there has been a doubling of water developments on southern New Mexico rangelands over the past 40 years (Torell et al. 2000). Only a slight increase in new fencing has occurred since 1960 .

Total livestock numbers for $\mathrm{New}$ Mexico counties are reported annually by the New Mexico Agricultural Statistics Service (2000). In the 6 sampled counties total beef cattle numbers steadily increased from 193,310 during 1960 to 251,350 head in 1980. However, cattle numbers since 1980 have declined to around 220,000 head in 2000 .

\section{Management Implications}

Our study showed that $38 \%$ of Bureau of Land Management rangeland sites we monitored in southwestern New Mexico were in late seral or climax ecological condition in the 1997-1999 period compared to $25 \%$ in the $1952-1982$ period (Table 5). We believe our study sites are fairly representative of BLM rangelands in southwestern New Mexico. Several studies reviewed by Holechek et al. (2001) show that late seral condition rangeland

(a) 
Donahue, D. L. 1999. The western range revisited: Removing livestock from public lands to conserve biodiversity. Univ. of Oklahoma Press, Norman, Okla.

Fleck, J. 1998. Studying droughts legacy. Albuquerque J. Sunday, February 1, 1998.

Hector, D.P. 1987. The decline of the aplomado falcon in the United States. American Birds 41:381-389.

Herbel, C. H. and R. P. Gibbens. 1996. Postdrought vegetation dynamics on arid rangelands in southern New Mexico. N. Mex. Agr. Exp. Sta. Bull. 776.

Herbel, C.H. and W.L. Gould. 1995. Management of mesquite, creosote bush, and tarbush with herbicides in the northern Chihuahuan Desert. New Mexico Agr. Exp. Bull. 775 .

Herbel, C. H., F. N. Ares, and R. A. Wright. 1972. Drought effects on a semidesert grassland range. Ecol. 53:1084-1093.

Holechek, J. L. 1992. Financial benefits of range management practices in the Chihuahuan Desert. Rangelands 14:279-282.

Holechek, J. L. and D. Galt. 2000. Grazing intensity guidelines. Rangelands 22:11-14.

Holechek, J. L., A. Tembo, A. Daniel, M. J. Fusco, and M. Cardenas. 1994. Long term grazing influences on Chihuahuan desert rangeland. Southwestern Naturalist 39:342-349.

Holechek, J. L., R. D. Pieper, and C. H. Herbel. 2001. Range management: principles and practices. $4^{\text {th }}$ Edition. Prentice-Hall Inc., Upper Saddle River, N. J.

Holechek, J. L., M. G. Thomas, D. Galt, and F. Molinar. 2000. Conservative and moderate stocking effects on Chihuahuan Desert forage production. Proc. West. Sect. Amer. Soc. Anim. Sci. 51:257-260.

Houston, W. R. and R. R. Woodward. 1966. Effects of stocking rates on range vegetation and beef cattle production in the northern Great Plains. U.S. Dept. Agr. Tech. Bull. 1357.

Hughes, L. E. 1982. A grazing system for the Mojave desert. Rangelands 2:17-18.
Hutchings, S. and R. C. Holmgren. 1959. Interpretation of loop-frequency data as a measure of plant cover. Ecol. 4:668-677.

Johnson, W. M. 1953. Effect of grazing intensity upon vegetation and cattle gains on ponderosa pine-bunchgrass ranges of the front range of Colorado. U.S. Dept. Agr. Circ.

Klipple, G. E. and D. F. Costello. 1960. Vegetation and cattle responses to different intensities of grazing on shortgrass ranges of the central Great Plains. U.S. Dept. Agr. Circ. 929.

Martin, S. C. 1975. Stocking strategies and net cattle sales on semi-desert range. U.S. Dept. Agr. For. Serv. Res. Pap. RM-146.

Martin, S. C. and D. R. Cable. 1974. Managing semidesert grass-shrub ranges: Vegetation responses to precipitation, grazing, soil texture, and mesquite control. U.S. Dept. Agr. Tech. Bull. 1480.

Meko, D., C. W. Stockton, and W. R. Boggess. 1995. The tree-ring record of severe sustained drought. Water Res. Bul. 31:789-801.

Molinar, F. 1999. Effect of honey mesquite cover and soil depth on forage production in the Chihuahuan Desert. Ph.D. Thesis, New Mexico State University, Las Cruces, N.M.

National Oceanic and Atmospheric Administration. 1999. Climatological data annual summary, New Mexico, 1999. National Climatic Data Center, Asheville, N.C.

Nelson, T., J. L. Holechek, R. Valdez, and M. Cardenas. 1997. Wildlife numbers on late and mid seral Chihuahuan Desert rangelands. J. Range Manage. 50:593-599.

New Mexico Agricultural Statistics Service. 2000. New Mexico Agricultural Statistics, 1960 to 2000. New Mexico Dept Agr., Las Cruces, N.M.

Parker, K. W. 1951. A method for measuring trend in range condition in national forest range condition in national forest ranges Fort Collins, Colo. U.S. Dept. of Agr., Forest Service, Rocky Mountain Forest and Range Exp. Sta.
Paulsen, H. A. and F. N. Ares. 1962. Grazing values and management of black grama and tobosa grasslands and associated shrub ranges of the southwest. U.S. Dept. Agr. Tech. Bull. 1270

Pearson, H. A. 1973. Calculating grazing intensity for maximum profit on ponderosa pine range in northern Arizona. J. Range Manage. 26:277-278.

Pieper, R. D. and K.C. McDaniel. 1989. Ecology and management of broom snakeweed. New Mexico Agr. Exp. Bull. 751.

Quigley, T. M., J. M. Skovlin, and J. P. Workman. 1984. An economic analysis of two systems and three levels of grazing on ponderosa pine-bunchgrass range. J. Range Manage. 37:309-312.

Smith, J. G. 1962. An appraisal of the loop transect method for estimating root crown area changes. J. Range Manage. 15:72-78.

Steel, R. G. D. and J. H. Torrie. 1980. Principles and procedures of statistics. $2^{\text {nd }}$ Ed. McGraw-Hill Book Co., New York

Torell, L.A., J. M. Hawkes, and S.A. Bailey. 2000. Range livestock cost and return estimates from New Mexico, 1997. New Mexico Agr. Exp. Sta. Res. Rep. 738.

United States Department of Interior (USDI). 1999. Public land statistics. U.S. Department of Interior. Bureau of Land Manage.

Valentine, K. A. 1970. Influence of grazing intensity on improvement of deteriorated black grama range. New Mexico Agr. Exp. Stn. Bull. 553

Winder, J. A., C. C. Bailey, M. Thomas, and J. Holechek. 2000. Breed and stocking rate effects on Chihuahuan Desert cattle production. J. Range Manage. 53:32-38.

Wuerthner, G. 1990. The price is wrong. Sierra 25:38-48. 


\title{
Population cycles of broom snakeweed in the Colorado Plateau and Snake River Plains
}

\author{
M.H. RALPHS AND K. D. SANDERS
}

Authors are Rangeland Scientist, USDA/ARS Poisonous Plant Lab., 1150 E. 1400 N., Logan Utah 84341; and Professor, Rangeland Ecology and Management, Univ. Idaho, PO Box 1827, Twin Falls, Ida 83303.

\section{Abstract}

Broom snakeweed (Gutierrezia sarothrae (Pursh) Britt. \& Rusby) is one of the most widespread range weeds in North America. The objective of this study was to monitor broom snakeweed populations in the salt-desert shrub community of the Colorado Plateau and in crested wheatgrass (Agropyron desertorum (Link) Schultes) seedings typical of the Snake River Plains and Great Basin, and determine if its population cycles are related to precipitation patterns. Foliar cover of broom snakeweed and associated plant species was measured along 7.6 or $33 \mathrm{~m}$ transects by the line intercept technique. Density of snakeweed age classes (seedling, juvenile, mature) was counted in $1 \mathrm{~m}^{2}$ quadrats at the beginning and end of each transect. Correlations were made between snakeweed cover and density, and seasonal precipitation. The snakeweed population at the Colorado Plateau site completed 2 cycles over the 13 year study period, dying out in the drought of 1989-90 and again in 2001. There were positive correlations between density of snakeweed classes and seasonal precipitation: seedlings with spring precipitation $(r=0.63)$; juveniles with winter precipitation $(r=0.69)$; and mature plants with previous fall precipitation $(r=0.62)$. Only 1 cycle occurred at the Snake River Plains site. Following the snakeweed invasion into crested wheatgrass seedings in the mid 1980's, the population was at the top of its population cycle when the study began in 1990, dropped back and fluctuated between 6-10\% cover from 1992 to 1999, and died out in 2001. Although density of mature plants did not change much during the middle part of the study, the change in snakeweed cover was correlated with spring $(r=$ $0.81)$ and total precipitation $(r=0.60)$, reflecting increase and decrease in size of plants in response to precipitation.

Key Words: broom snakeweed, Gutierrezia sarothrae, population cycle, poisonous plant.

Broom snakeweed (Gutierrezia sarothrae (Pursh) Britt. \& Rusby) is the most ubiquitous range weed in North America. It extends from the cold-temperate climate of Canada to the sub tropical areas of Mexico, from the sub-humid Great Plains to the arid deserts of the Great Basin, and up the Sierra Nevada and Rocky Mountains. It is now a principal component of the following major plant communities: creosote bush, desert grassland, short-grass prairie, salt-desert shrub, sagebrush steppe, pinyon/juniper, and mountain brush.

Manuscript accepted 20 Sept. 02.

\section{Resumen}

"Broom snakeweed" (Gutierrezia sarothrae (Pursh) Britt. \& Rusby) es una de las malezas de pastizal más ampliamente esparcidas en Norte América. El objetivo de este estudio fue monitorear las poblaciones de "Broom snakeweed" en las comunidades arbustivas del desierto salado de la meseta Colorado y en las siembras de "Crested wheatgrass" (Agropyron desertorum (Link) Schultes) típicas de las planicies del Río "Snake" y la Gran Cuenca y determinar si sus ciclos de población están relacionados a los patrones de precipitación. La cobertura foliar de "Broom snakeweed" y de las plantas asociadas se midió a lo largo de transecto de 7.6 o $33 \mathrm{~m}$ mediante la técnica de intercepción de línea. La densidad por clases de edad de "snakeweed" (plántula, juvenil y madura) se contó en cuadrantes de $1 \mathrm{~m} 2$ al inicio y final de cada transecto. Se hicieron correlaciones entre la cobertura y densidad de "snakeweed" y la precipitación estacional. La población de "snakeweed" del sitio meseta Colorado completó dos ciclos en los 13 años del período de estudio, muriendo en la sequía de 1980- 1990 y de nuevo en 2001. Hubo correlaciones positivas entre la densidad de clases de "snakeweed" y la precipitación estacional: las plántulas con la precipitación de primavera $(r=0.63)$; juveniles con la precipitación de invierno ( $r=0.69)$ y las plantas maduras con la precipitación del otoño previo ( $r=0.62$ ), en el sitio del Río "Snake" solo ocurrió un ciclo. Después de la invasión del "Snakeweed" en las siembras de "Crested wheatgrass", a mediados de la década de 1980, la población estuvo en la cumbre de su ciclo de población cuando el estudio comenzó en 1990, retrocedió y fluctuó entre 6-10\% de cobertura de 1992 a 1999 y murió en 2001. Aunque la densidad de plantas maduras no cambio mucho durante la parte media de este estudio, el cambio de cobertura del "Snakeweed"'estuvo correlacionado con la precipitación de primavera $(r=0.81)$ y la precipitación total $(r=0.60)$, reflejando aumentos y disminuciones en el tamaño de las plantas en respuesta a la precipitación.

The early literature associated the increase of broom snakeweed with overgrazing, which reduced desirable vegetation and allowed broom snakeweed to increase where it already existed, and invade deeper soils and more productive sites (reviewed by McDaniel and Torrell 1987). However, it has even increased in good condition plant communities in the absence of grazing (Chew 1982, Hennessy et al. 1983). Other disturbances (such as fire, drought and chaining) can also cause it to increase (Arnold et al. 1964, Parker 1939, USFS 1937). It is very competitive with desirable grasses and greatly suppresses forage production (McDaniel et al. 1982, Ueckert 1979). It is not palatable to most 
large ungulates (Pieper 1989), and it is toxic to livestock causing abortions (Dollahite and Anthony 1957). Platt (1959) ranked it one of the most undesirable plants in the various regions of the West. On many localized rangelands of the southwest, it is the most significant problem limiting forage and livestock production.

Broom snakeweed is a short-lived, perennial, suffrutescent shrub whose populations appear to be related to climatic patterns. In southern New Mexico, broom snakeweed populations died out during droughts in 1970-71, 1984, and 1994, but rapidly reestablished from seedlings during the following wet winters and springs (Pieper and McDaniel 1989, Beck et al. 1996, 1999, McDaniel et al. 2000).

The objective of this study was to monitor broom snakeweed populations in the salt-desert shrub community of the Colorado Plateau and in crested wheatgrass seedings typical of the Snake River Plains and Great Basin, and determine if changes in its cover and density were related to precipitation patterns.

\section{Methods}

The Colorado Plateau site was located $10 \mathrm{~km}$ south of Ferron, Ut. at $1,890 \mathrm{~m}$ elevation ( $\mathrm{N} 38^{\circ} 57.74^{\prime}$, W $\left.111^{\circ} 12.17^{\prime}\right)$. Annual precipitation averaged $22 \mathrm{~cm}$ with a bimodal pattern of winter snow and summer monsoonal thunderstorms. Soils were fairly uniform Ravola loam (fine-silty, mixed, active, calcareous, mesic Typic Torrifluvent) derived from alluvium from Mancos shale and sandstone benches. The range site was a desert loam with a saltdesert shrub plant community consisting of shadscale (Atriplex confertifolia (Torr. \& Frem.) Wats.), Gardner saltbush (A. gardneri (Moq.) D. Dietr.), mat saltbush (A. corrugata Wats), curley grass (Hilaria jamesii (Torr.) Benth.), Indian ricegrass (Stipa hymenoides R. \& S.), and squirreltail (Elymus elymoides (Raf.) Swezey). Broom snakeweed is considered an invader species on this site (USDA/SCS 1970).

At Ferron, 2 sites were selected about 4 $\mathrm{km}$ from each other. Soils and vegetation communities were as uniform as possible. One exclosure (50 by $110 \mathrm{~m}$ ) was constructed at each site to evaluate the effect of grazing on vegetation change inside and outside the exclosure. Cattle grazed this site during winter and early spring. Three permanent $33 \mathrm{~m}$ transects were systematically located inside and 3 outside each exclosure and rebar stakes were placed at the beginning and end of each transect. Foliar cover of broom snakeweed and associated species was measured by the line intercept method by stretching a tape between the stakes and measuring the intercept of each species along the tape. Density of the following broom snakeweed age classes: seedling (single stem < $6 \mathrm{~cm}$ tall), juvenile (less than 5 stems arising from a crown), and mature (more than 5 stems and having a woody base), was counted in $1 \mathrm{~m}^{2}$ quadrats placed at the rebar stakes at the beginning and end of each transect $(n=6$ both inside and outside each exclosure). Collection of cover data began in 1987 and both cover and age class density data were taken from 1989 to 2001 in June each year.

The Snake River Plains location was on the Lee A. Sharp Experimental Range about $13 \mathrm{~km}$ east of Malta Ida. (N $42^{\circ}$ $\left.18.96^{\prime}, \mathrm{W} 113^{\circ} 13.05^{\prime}\right)$. Elevation was $1460 \mathrm{~m}$, and average annual precipitation was $27 \mathrm{~cm}$. Soils were the Sublette series, (Coarse-loamy, mixed superactive Pache Argicryoll) and originally supported a Wyoming big sagebrush/squirreltail/ Sandberg bluegrass vegetation community. The area was plowed and seeded in 1952 to control halogeton (Halogeton glomeratus (Bieb.) C.A. Mey). Pre-dominant vegetation now consists of crested wheatgrass (Agropyron desertorum (Link) Schultes), Sandberg bluegrass (Poa secun$d a$ Presl) with varying amounts of Wyoming big sagebrush (Artemesia tridentata var. wyomingensis (Beetle \& Young) Welsh) and broom snakeweed. Spring/fall grazing is rotated each year on the site. Broom snakeweed established

Table 1. Correlation coefficients ( $r$ ) between density of broom snakeweed age classes and cover of forage classes with seasonal and total water year precipitation. Correlation of snakeweed cover with cover of shrubs and grass.

\begin{tabular}{|c|c|c|c|c|c|c|c|}
\hline \multirow[b]{2}{*}{ Location } & \multirow[b]{2}{*}{ Season } & \multicolumn{2}{|c|}{ Snakeweed Density } & \multicolumn{4}{|c|}{ Cover } \\
\hline & & Mature & Juvenile & Seedling & Snake & Shrub & Grass \\
\hline \multirow[t]{6}{*}{ Ferron } & Fall & $0.62 *$ & 0.07 & 0.23 & $0.64 * *$ & 0.15 & 0.38 \\
\hline & Winter & 0.28 & $0.69 * *$ & -0.10 & -0.16 & 0.49 & 0.47 \\
\hline & Spring & -0.18 & 0.11 & $0.62 *$ & 0.26 & -0.08 & -0.29 \\
\hline & Summer & 0.01 & -0.41 & 0.43 & -0.02 & -0.14 & -0.35 \\
\hline & Total & 0.04 & 0.07 & $0.54 \mathrm{t}$ & 0.28 & 0.17 & -0.29 \\
\hline & Snakeweed & & & & 1.0 & $-0.26 * *$ & $-0.22 * *$ \\
\hline \multirow[t]{6}{*}{ Malta } & Fall & 0.26 & 0.02 & 0.36 & 0.09 & -0.01 & 0.27 \\
\hline & Winter & 0.10 & 0.09 & -0.07 & -0.17 & $0.63 *$ & $0.53^{t}$ \\
\hline & Spring & -0.10 & 0.21 & 0.08 & $0.81 * *$ & 0.15 & $0.59^{t}$ \\
\hline & Summer & -0.04 & -0.20 & 0.18 & 0.26 & -0.20 & 0.01 \\
\hline & Total & 0.05 & 0.09 & 0.24 & $0.60^{t}$ & .031 & $0.75 * *$ \\
\hline & Snakeweed & & & & 1.0 & $-0.34 * *$ & 0.03 \\
\hline
\end{tabular}

Significant correlations $* * \mathrm{p}<0.01, * \mathrm{p}<0.05, \mathrm{t} \mathrm{p}<0.10$. first in the heavily grazed, spring-use experimental pasture where crested wheatgrass had thinned out. Seed was carried by prevailing southeasterly winds from this site and established in healthy crested wheatgrass seedings throughout the pastures during the wet years of 1982-1984, reaching its peak from 1987-1990 (Sanders, personal observation).

At Malta, 2 macroplots were selected about $100 \mathrm{~m}$ apart. A permanent $33 \mathrm{~m}$ transect was established on each macro plot and marked with rebar stakes. Ten, $7.6 \mathrm{~m}$ lateral transects at right angles from the main transect $(5 /$ side) were randomly selected and marked at the ends. Foliar cover of each species was measured by the line intercept method along each of the lateral transects. Density of broom snakeweed age classes were counted in $1 \mathrm{~m}^{2}$ quadrats at the beginning and end of each of the lateral transects $(n=20$ on each macro plot). Cover data collection began in 1990 and both cover and density data were collected from 1991 to 2001 in September each year.

The Ferron site was initially established to evaluate the effects of grazing on the plant community. When the snakeweed population trends were recognized, measurements of snakeweed on this study site continued. The Malta site was later selected because of the increasing snakeweed population. An expanded and more efficient experimental design was constructed to measure changes in the snakeweed population. Although the experimental design at the 2 locations were different, necessitating separate analyses, the results are similar and can be discussed together. 


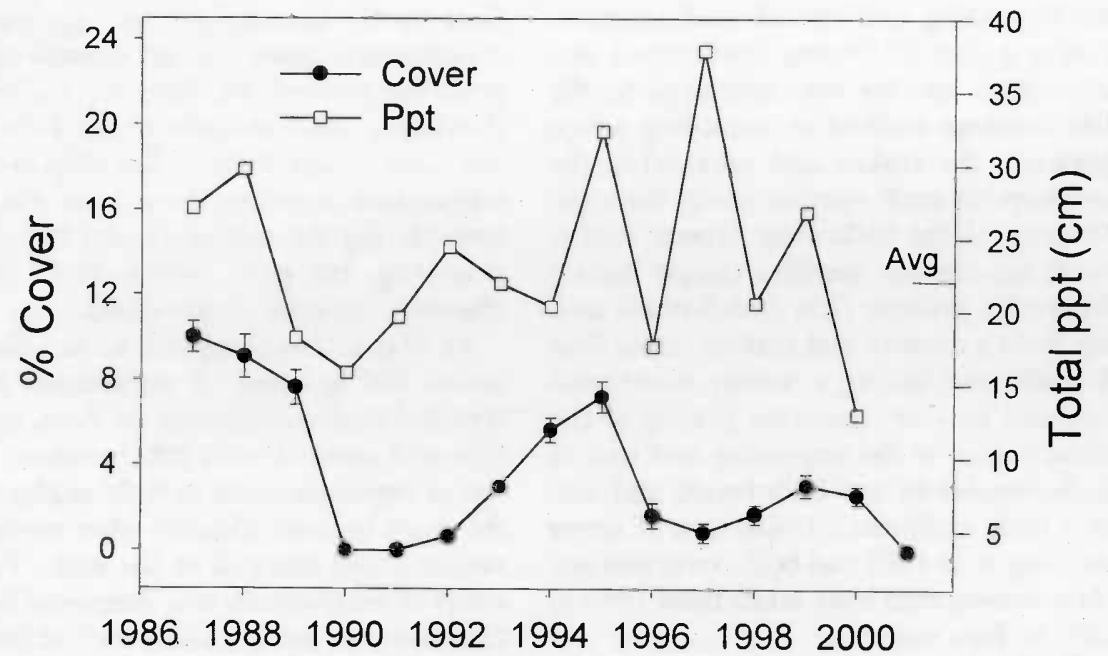

Fig. 1. Snakeweed cover and annual precipitation at Ferron, Ut. (error bars are SE). Average annual precipitation was $22 \mathrm{~cm}$.

At Ferron, density of broom snakeweed age classes, and cover of snakeweed and associated forage classes (shrubs and grasses) was analyzed by the Mixed procedure ANOVA in a repeated measures design using the compound symmetry covariate structure, comparing sites, exclosures (grazing vs no grazing), and years. At Malta, data were analyzed by a similar model comparing macro plots and years. Correlations were made between broom snakeweed cover and density of each age class with seasonal precipitation for the current water year, and also lagged precipitation from the previous year. Correlations were also made between cover of snakeweed and shrub and grass cover at both locations.

\section{Results}

\section{Ferron, Ut.} Ferron sites in broom snakeweed cover or density $(p>0.22)$. There was no difference in these parameters between the exclosures and grazed areas ( $p>0.21)$, indicating that grazing in early spring had no effect on the snakeweed population at this location during this 13 year study. There were differences among years $(\mathrm{p}<$ 0.0001 ) and some correlations with seasonal precipitation (Table 1).

The correlation between snakeweed cover and total precipitation was not strong $(r=0.28, p=0.34$ for current year,
There was no difference between the 2

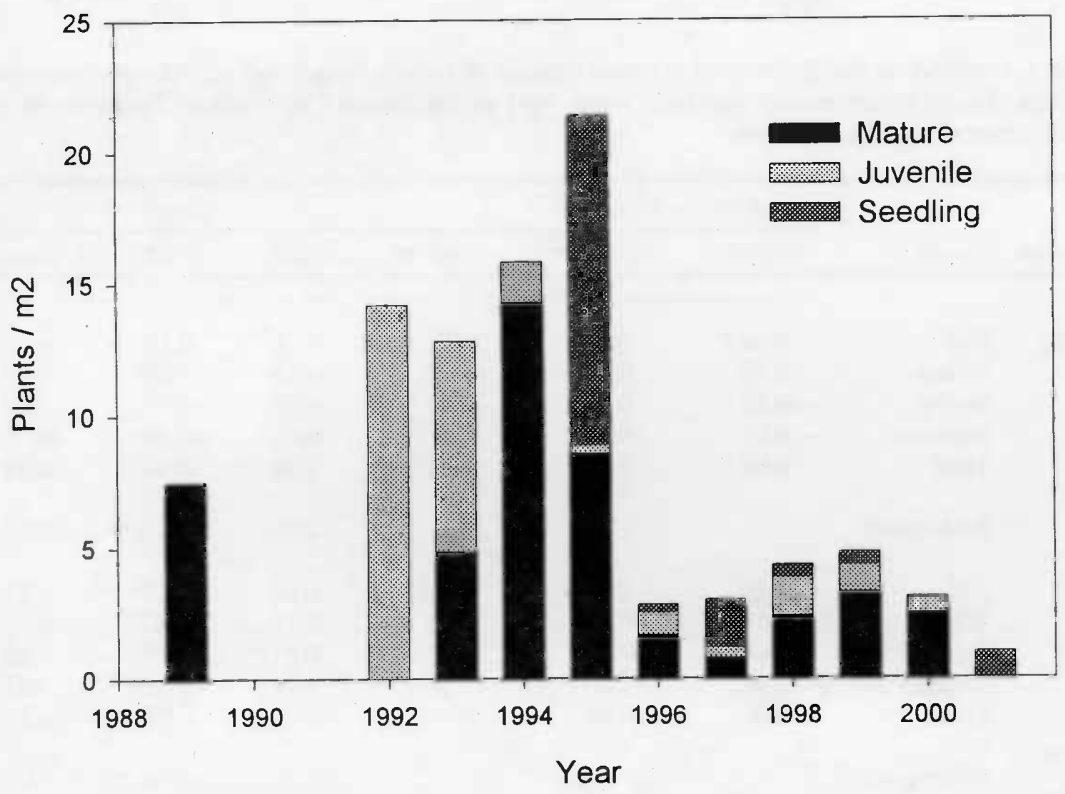

Fig. 2. Density of snakeweed age classes at Ferron, Ut.

and $\mathrm{r}=0.24, \mathrm{p}=0.41$ lagged 1 year) (Table 1), but the trends were similar for the first part of the study (Fig. 1). The snakeweed population was highest when the study began in 1987, which coincided with the wet years of 1987 and 1988 . Precipitation was below average in 1989 and 1990, and the snakeweed population declined and completely died out in 1990. Precipitation increased to about average in 1992 and then increased to $50 \%$ above average in 1995, with snakeweed cover continuing to increase. Both precipitation and snakeweed cover declined in 1996. Precipitation was very high in 1997 and 1999, but snakeweed cover increased only slightly, thus causing the divergence and resulting low correlation. The snakeweed population died out again in 2001.

Density of snakeweed age classes increased following the 1989-90 drought (Fig. 2). Juvenile plants appeared in 1992 following above average winter precipitation $(r=0.69, p=0.01)$ and survived and grew into about the same number of mature plants in 1994. Most of these mature plants died back in 1996 in response to the drop in the previous fall precipitation $(r=0.62, p=0.02)$. The seedling stage did not appear in this cycle. Perhaps germination occurred following abundant late summer rains in 1991 and plants were established as juveniles when measured in June 1992. There was a large influx of seedlings in 1995 that corresponded with high spring precipitation that year $(r=0.63, p=0.02)$. Few of these seedlings survived due to the low precipitation in 1996 (Fig. 2).

There was a weak but significant negative correlation between cover of snakeweed and other shrubs $(r=-0.22, p=$ 0.003 ), and between snakeweed and grasses $(\mathrm{r}=-0.26, \mathrm{p}=0.0006)$, particularly curley grass (Fig. 3). Cover of grass and shrubs increased in 1991 and 1992 when snakeweed populations were down, then declined as snakeweed increased in 1994 and 1995. Snakeweed cover declined in 1996 and 1997, and grass cover subsequently increased from 1998 to 2001, in spite of average or below average precipitation.

Malta, Ida.

The snakeweed population was highest when the study began in $1990(14 \%$ cover), declined to $6-10 \%$ cover from 1992 to 1999 , then nearly died out in 2001 (year effect $p<0.001$ ) (Fig. 4). Snakeweed cover was correlated with total annual precipitation $(r=0.60, p=0.06)$, and particularly with spring precipitation $(\mathrm{r}=0.81, \mathrm{p}=0.004)$. 


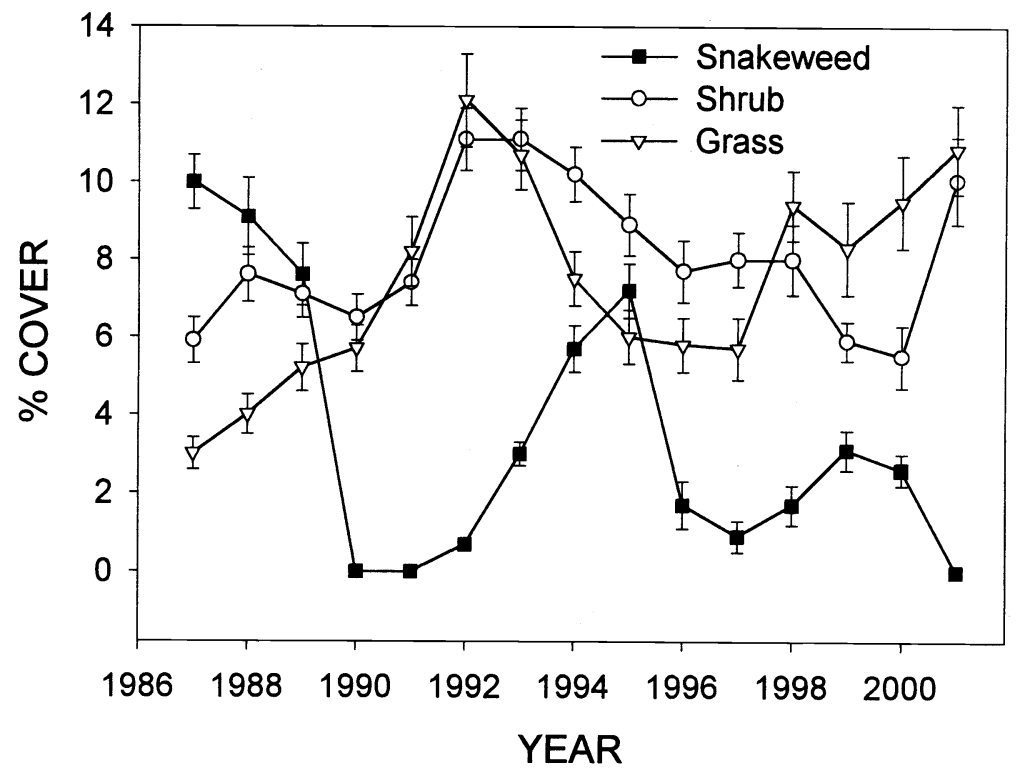

Fig. 3. Cover of snakeweed in relation to grasses and shrubs at Ferron, Ut. (error bars are SE).

There was a progression through the snakeweed age classes (Fig. 5 ) and some recruitment of new plants into the population. Seedlings were very abundant in 1993, corresponding to the high spring precipitation that year. Another crop of seedlings grew in 1994. A few seedlings apparently survived and progressed into the Juvenile category in 1994, and about half of the 1994 seedlings progressed to Juveniles and peaked in 1995. There was a slight increase in the number of mature plants in 1996, indicating the progression of some juveniles into the mature stage. Although there appears to be relationships between seedlings, juveniles and precipitation, correlations were not significant $(\mathrm{P}>0.05)$.

Grass, sagebrush, and snakeweed cover followed precipitation patterns during the first part of the study; increasing in wet years and declining in dry years (Fig. 6). Towards the end of the study, sagebrush cover continued to increase as snakeweed cover declined. There was a negative correlation between sagebrush cover and snakeweed $(r=-0.34, p=0.0001)$ suggesting that increasing sagebrush was reducing snakeweed. Grass cover appears to be more affected by total precipitation $(\mathrm{r}=0.75, \mathrm{p}=0.01)$ than competition from snakeweed or sagebrush (Table 1).

\section{Discussion}

Snakeweed populations in our study cycled on the Colorado Plateau and Snake River Plains; dying back during drought and increasing in seasons of abundant precipitation. Snakeweed population cycles in the Southwest have also been associated with climate patterns (Pieper and McDaniel 1989, McDaniel 1989, Beck et al. 1996, 1999, McDaniel et al. 2000 ). McDaniel and Ross (2001) followed 2 snakeweed populations for 20 years. A severe regional drought occurred during the summer of 1980, causing a significant die off of snakeweed plants at Vaughn, N.M., but snakeweed plants survived at Roswell, N.M., less than $80 \mathrm{~km}$ away. The following spring of 1981 had twice the average precipitation, and snakeweed annual precipitation was $27 \mathrm{~cm}$. seedlings established at both locations and grew into uniform, even-aged stands. Most snakeweed plants were killed at Roswell by root borers (Crossidius puchellum) in 1987-88 and the site remained free of snakeweed. The Vaughn population declined in the early 1990's and has remained low. They concluded that micro environmental factors unique to each site determined germination, establishment and death of the respective populations, independent of the broad regional climatic patterns.

The micro environmental factors governing snakeweed germination, establishment and death have been described. Broom snakeweed is a short-lived perennial that propagates by seed in years of optimal environmental conditions, and dies out from drought stress or insect damage . It is a prolific seed producer ranging from 2036-3928 seeds/plant (Wood et al. 1997). Seed are dispersed over winter, mainly during high winds and snowfall, and most seed fall near the parent plant. Seed viability remains high over winter (70 - 80\%) but drops to 0 in late May and June, suggesting that seed remaining on the soil surface degrade rapidly. Germination is stimulated by light, temperature and soil moisture. Seeds must remain partially exposed on the soil surface (Mayeux 1983) with alternating day/night temperatures 15 and $30^{\circ} \mathrm{C}$ (Mayeux and Leotta 1981). Germination depends on saturated surface soil moisture for at least 4 days (Wood et al. 1997), requiring $>25 \mathrm{~mm}$ precipitation that keeps the soil surface wet for several days. Mortality of seedlings was $>70 \%$ the first

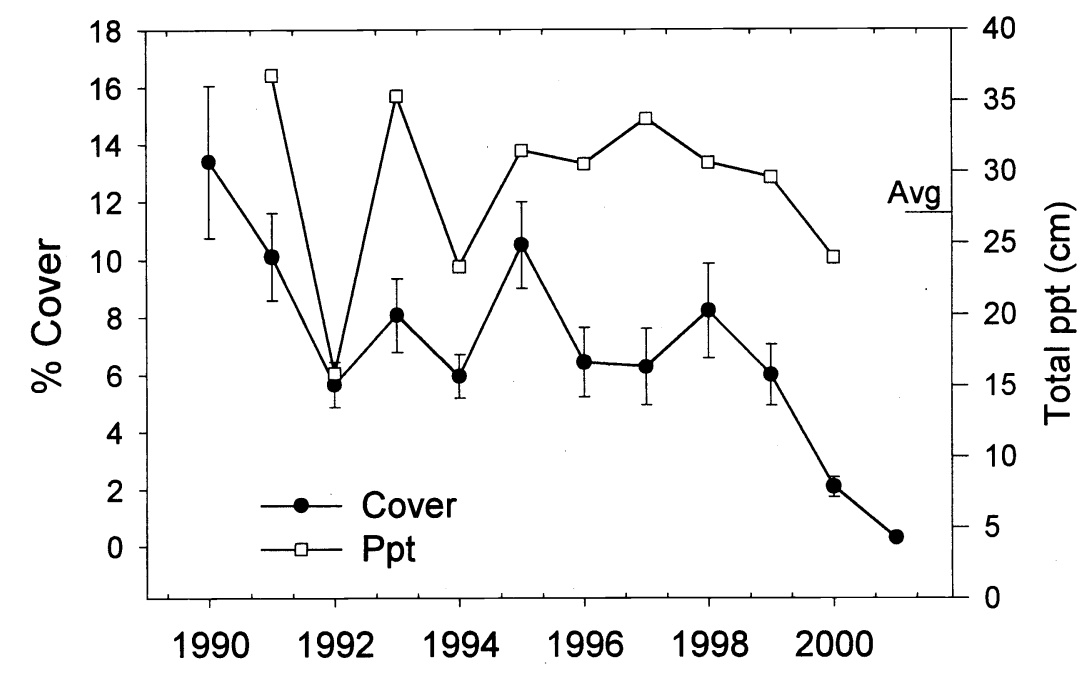

Fig. 4. Snakeweed cover and annual precipitation at Malta, Ida. (error bars are SE). Average 


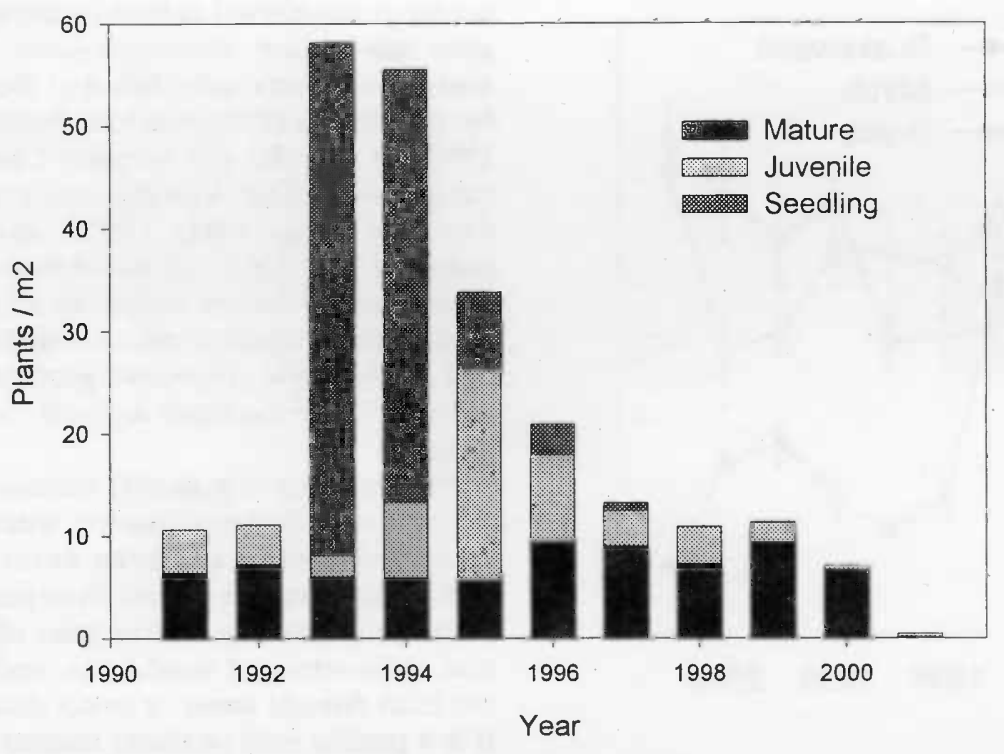

Fig. 5. Density of snakeweed age classes at Malta, Ida.

year, but those plants that survive may live 4-7 years (Dittberner 1971).

Survival of snakeweed is dependent upon soil moisture. Soil water content in the top $20-30 \mathrm{~cm}$ is the single most important factor determining mortality (Wan et al. 1993b). As soil water stress increases seasonally or during drought, stomates do not close completely, thus transpiration continues (Wan et al. 1993a, DePuitt and Caldwell 1975). This luxuriant use of water depletes soil moisture when snakeweed grows in early spring, resulting in its competitive advantage over warm-season grasses that grow later. Leaf growth declines (Wan et al. 1993a) and leaves are eventually shed to cope with water stress, but stems continue photosynthesis (DePuitt and Caldwell 1975). However, as drought stress increases, stomates remain open transpiring water, causing tissue dehydration and xylem embolism. Death occurs rapidly $(<10$ days) when soil water potential drops below $-7.5 \mathrm{MPa}$ and leaf water content declines to 50\% (Wan et al. 1993b). In our study, we recorded sharp declines in snakeweed populations during years and seasons of low precipitation.

Other factors besides drought may con-

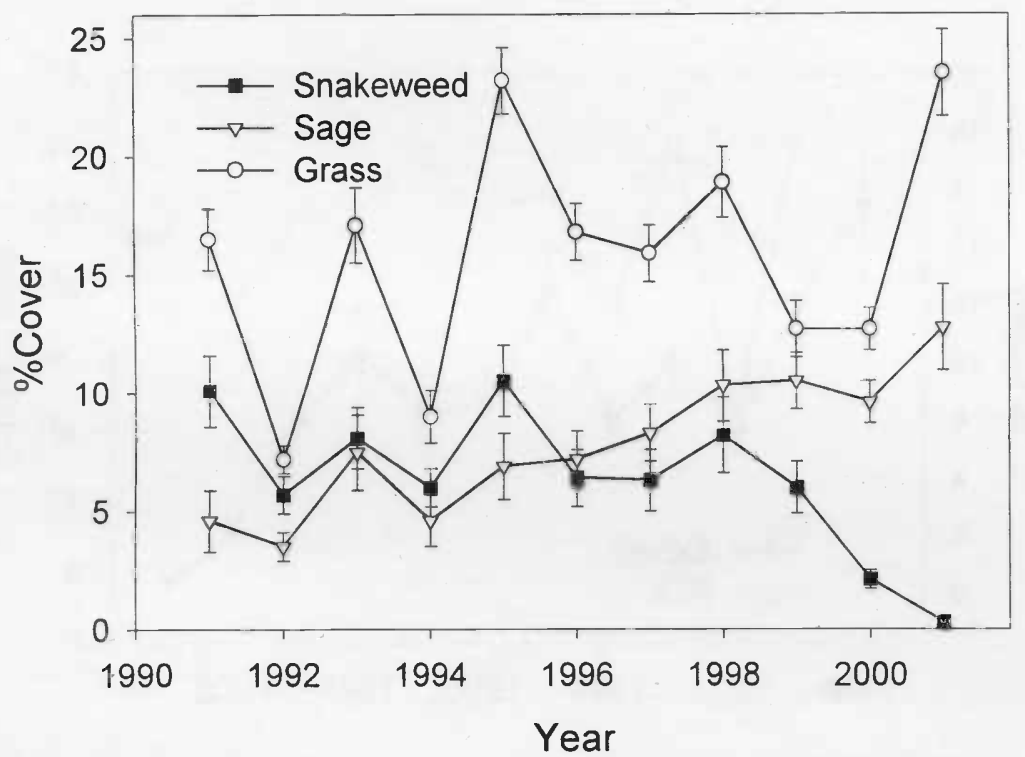

Fig. 6. Cover of snakeweed in relation to grasses and sagebrush at Malta, Ida. (error bars are SE). tribute to snakeweed mortality. Many insects feed on snakeweed and cause considerable mortality under certain conditions (Richman and Huddleston 1981, Foster et al. 1981, Wangberg 1982, Parker 1984). Three species of insects, the redlegg grasshopper Hesperotettix viridis, the leaf-tyer Synnoma lynosyrana, and the root-boorer Crossidius pulchellus were evaluated for their potential as biological control agents for snakeweed (Thompson and Richman 1989).

Perhaps the most disagreeable weedy trait of broom snakeweed is its competitive ability against desirable forage, particularly warm-season grasses. Grass production increased several fold when snakeweed was controlled (Dwyer 1958, Ueckert 1979). Greater than $75 \%$ of snakeweed must be removed to realize the increased forage production, else the remaining plants simply increased in size and maintained the same degree of competition (McDaniel et al. 1982). McDaniel et al (1993) described a negative sigmoidal and exponential relationship between snakeweed and grass biomass, which confirms that almost total control is needed to remove snakeweed suppression of grasses.

However, broom snakeweed may not compete with cool-season grasses. Jameson (1966) reported no competition between broom snakeweed and the cool-season squirreltail (Elymus elymoides (Raf.) Swezey), but there was a significant negative correlation with the warm-season blue grama (Bouteloua gracilis (H.B.K.) Sag. ex Steudel). In our study, cover of the warmseason curley grass was negatively correlated with snakeweed cover at the Colorado Plateau site. Curley grass increased in years when snakeweed died out, and declined as snakeweed increased. Yet, there was no correlation between snakeweed and the cool-season crested wheatgrass at the Snake River Plain site. Cover of crested wheatgrass was correlated with annual precipitation patterns, but was independent of snakeweed. We speculate that since coolseason grasses grow at the same time as broom snakeweed in early spring they may compete equally for the stored winter and spring precipitation. Research is needed to determine competition between snakeweed and cool-season grasses.

\section{Conclusion}

Snakeweed populations in the Colorado Plateau and the Snake River Plains cycled over time and were related to precipitation patterns. The snakeweed population at 
Ferron completed 2 cycles over the 13 year study period, dying out in drought and establishing and increasing in wet years. Only 1 cycle occurred at the Snake River Plains site. Following the snakeweed invasion of crested wheatgrass seedings in the wet years of the mid 1980's, the population was highest at the beginning of the study in 1990 (14\% cover), dropped to $6 \%$ cover with the decline in precipitation in 1992, fluctuated slightly until 1999, then died out in response to drought in 2000 and 2001. There was little recruitment to this population, in spite of events of seedling (1993) and juvenile establishment (1995). McDaniel and Ross (2001) summarized the management alternatives to control snakeweed based on its stage in the population cycle: use prescribed burning in the early stages of the population cycle while there was sufficient grass cover to carry a fire; spray with herbicides when the population crowded out the grass; or simply wait for the population to die out from drought or insect damage. Knowledge of how to prevent establishment of snakeweed in wet years is still lacking.

\section{Literature Cited}

Arnold, J.F., D.A. Jameson, and E.H Reid. 1964. The pinyon - juniper type of Arizona: effects of grazing fire and tree control. USDA/FS Prod. Res. Rep. 84.

Beck, R.F., R.P. NcNeeley, and S.J. Muir. 1996. Effects of goats and drought on snakeweed. p.7 in: Abstracts, $49^{\text {th }}$ Annual Meeting, Soc. for Range Manage, Wichita Kans.

Beck, R.F., M. Nsinamwa, R. Santos, and R.D. Pieper. 1999. Dynamics of Gutierrezia sarothrae with drought and grazing. pp. 502-503 In: Eldridge and Freudenberger (Eds), Proc. VI International Rangeland Congress, Townsville Aust.

Chew, R.M. 1982. Changes in herbaceous and suffrutescent perennials in grazed and ungrazed desertified grassland in south eastern Arizona USA, 1958-1978. Amer. Midl. Nat. 108:159-169.

DePuit, E.J. and M.M. Caldwell. 1975. Gas exchange of three cool semi-desert species in relation to temperature and water stress. $\mathbf{J}$. Ecol. 63:835-858.

Dittberner, D.L. 1971. A demographic study of some semi-desert grassland plants. M.S Thesis, New Mexico State Univ., Las Cruces N.M.

Dollahite, J.W. and W.V. Anthony. 1957. Poisoning of cattle with Gutierrezia microcephala, a perennial broomweed. J. Amer. Vet. Med. Assoc. 130:525-530.

Dwyer, D.D. 1958. Competition between forbs and grasses. J. Range Manage. 11:115-118
Foster, D.E., D.N. Ueckert and C.J. Deloach. 1981. Insects associated with broom snakeweed (Xanthocephalum sarothrae) and threadleaf snakeweed (X. microcephala) in west texas and eastern New Mexico. J. Range Manage. 34:446-454

Hennessy, J.T., R.P. Gibbens, J.M. Tramble, and M. Cardenas. 1983. Vegetation changes from 1935-1980 in mesquite (Prosopis glandulosa) dunelands and former grasslands of southern New Mexico USA. J. Range Manage. 36:370-374.

Jameson, D.A. 1966. Competition in a blue grama - broom snakeweed - Actinea community and responses to selective herbicides. J. Range Manage. 19:121-124.

Mayeaux, H.S. Jr. 1983. Effects of soil texture and seed placement on emergence of four sub shrubs. Weed Sci. 31:380-384.

Mayeaux, H.S. Jr. and L.Leotta. 1981 Germination of broom snakeweed (Gutierrezia sarothrae) and threadleaf snakeweed (G. microcephala) seed. Weed Sci. 29:530-534.

McDaniel. K.C. 1989. Snakeweed populations in New Mexico, 1979-1989. pp. 13-25 In: E.W. Huddleston and R. D. Pieper (eds), Snakeweed: Problems and Perspectives, New Mexico Agr. Exp. Sta. Bull. 751.

McDaniel, K.C. and T.T. Ross. 2001. Snakeweed: poisonous properties, livestock loss, and management considerations. J. Range Manage. (in review).

McDaniel, K.C. and L.A. Torell. 1987. Ecology and management of broom snakeweed. pp. 101-115 In: J.L. Capinera (ed.), Westview Press, Boulder, Colo.

McDaniel, K.C., D.B. Carrol, and C.R. Hart. 2000. Broom snakeweed establishment on blue grama grasslands after fire and herbicide treatments. J. Range Manage. 53:239-245.

McDaniel, K.C., R.D. Pieper, and G.B. Donart. 1982. Grass response following thinning of broom snakeweed. J. Range Manage. 35:219-222.

McDaniel, K.C., L.A. Torell, and J.W. Bain. 1993. Overstory-understory relationships for broom snakeweed-blue grama grasslands. J. Range Manage. 45:505-511.

Parker, K.E. 1939. The control of snakeweed in the southwest. S.W. For. Range Exp. Sta. Res. Note 76.

Parker, M.A. 1984. Local food depletion and the foraging behavior of a specialist grasshopper, Hesperotettix viridis. Ecology 65:824-835.

Pieper, R.D. 1989. Broom snakeweed content in herbivore diets. pp. 203-210, in: E.W Huddleston and R. D. Pieper (eds), Snakeweed: Problems and Perspectives, New Mexico Agr. Exp. Sta. Bull. 751.

Pieper, R.D. and K.C. McDaniel. 1989. Ecology and management of broom snakeweed. pp. 1-2 In: E.W. Huddleston and R. D. Pieper (eds), Snakeweed: Problems and Perspectives, New Mexico Agr. Exp. Sta. Bull. 751 .

Platt, K.B. 1959. Plant control - some possibilities and limitations. II Vital statistics for range management. J. Range Manage. 12:194-200.
Richman, D.B. and E.W. Huddleston. 1981. Root feeding by the beatle Crossidius pulchellus and other insects on broom snakeweed (Gutierrezia spp.) in eastern and central New Mexico. Environ. Entomol. 10:53-57.

Thompson, D.C. and D.B. Richman. 1989. The role of native insects as snakeweed biological control agents. pp 179-187 In: E.W. Huddleston and R. D. Pieper (eds), Snakeweed: Problems and Perspectives, New Mexico Agr. Exp. Sta. Bull. 751.

Ueckert, D.N. 1979. Broom snakeweed: effect on shortgrass forage production and soil water depletion. J. Range Manage. 32:216-220.

USDA FS. 1937. Range Plant Handbk. U.S. Gov. Printing Office. Washington D.C.

USDA SCS. 1970. Soil survey, Carbon Emery area, Utah.

Wan, C., R.E. Sosebee and B.L. McMichael. 1993a. Broom snakeweed responses to drought: I. photosynthesis, conductance, and water-use efficiency. J. Range Manage. 46:355-359.

Wan, C., R.E. Sosebee and B.L. McMichael. 1993b Broom snakeweed responses to drought: II. root growth, carbon allocation, and mortality. J. Range Manage. 46:360-363

Wangberg, J.K. 1982. Destructive and potentiallly destructive insects of snakeweed in western Texas and eastern New Mexico. J. Range Manage. 35:235-238.

Wood, B.L., K.C. McDaniel, and D. Clason. 1997. Broom snakeweed (Guterrezia sarothrae) dispersal, viability, and germination. Weed Sci. 45:77-84. 


\title{
Monitoring a half-century of change in a hardwood rangeland
}

\author{
KERRY L. HEISE AND ADINA M. MERENLENDER
}

Authors are Botanist and Staff Research Associate, Integrated Hardwood Range Management Program, Hopland Research and Extension Center, Hopland, Calif. 95449; and Cooperative Extension Specialist, Environmental Science, Policy, and Management, University of California, Berkeley, Calif. $94720-3110$.

\begin{abstract}
Changes in rangeland species composition can effect forage quality, ecosystem function, and biological diversity. Unfortunately, documenting species compositional change is difficult due to a lack of accurate historic records. We took advantage of herbarium records dating from the early 1950's to reconstruct the past flora of a 2,168 ha hardwood rangeland in Mendocino County, California , and then compared this to the current flora of the site. An inventory of vascular plants conducted from 1996 to 2001 added 44 native and 15 non-native species bringing the total number of species and infraspecific taxa at the study site to 671 . Of the original 612 species recorded prior to this study, 34 native and 1 non-native species could not be relocated. The percentage of non-native species increased from $19 \%$ in 1952 to $23 \%$ in 2001 . Based on estimates from the early 1950's, mid 1980's, and 1996 to 2001, at least 13 non-native species have increased in abundance, while some native species have decreased. Livestock grazing, competition with invasive species, conversions to different vegetation types, and transportation of propagules into the site by vehicles and livestock, combined with the difficulty of relocating rare species, are posed as the most likely causes for the documented changes.
\end{abstract}

Key Words: Northwest California, herbarium, oak woodlands, livestock, flora, invasive species

Hardwood rangelands in California cover an estimated 4.5 million ha and are characterized by an overstory canopy of hardwood trees, primarily in the genus Quercus. The overstory provides at least $10 \%$ cover; the understory is generally dominated by exotic annual grasses and forbs. Replacement of the native understory flora with a primarily non-native one occurred rapidly and on a very large scale over the past 200 years (Heady 1977, Mack 1989). The primary causes of this change are human induced such as livestock grazing, fire suppression, and facilitated dispersal (Rejmánek et al. 1991) resulting in an increased dominance by exotics and a subsequent loss of native species (Mooney and Drake 1987).

Change in understory species composition of oak woodlands, savanna, and grasslands represents a significant component of global environmental change including loss of biological diversi-

Authors wish to thank Chuck Vaughn, Bob Keiffer, and 2 anonymous reviewers for helpful comments on the manuscript.

Manuscript accepted 5 Oct. 01

\section{Resumen}

Cambios en la composición de especies del pastizal pueden afectar la calidad de forraje, la función del ecosistema y la diversidad biológica. Desafortunadamente, el documentar los cambios de la composición de especies es difícil debido a la falta de registros históricos certeros. Tomamos ventaja de los registros del herbario, que datan de inicio de la década de 1950, para reconstruir la flora pasada de 2,168 ha de un pastizal con árboles de madera dura en el condado de Mendocino, California, y la comparamos con la flora actual del sitio. Un inventario de las plantas vasculares conducido de 1996 al 2001 agregó 44 especies nativas y 25 especies no nativas totalizando 671el número de especies y taxas intraespecificas en el sitio de estudio. De las 612 especies originales registradas antes de este estudio, 34 nativas y una no nativa no pudieron ser relocalizadas. El porcentaje de especies no nativas se incrementó de $19 \%$ en 1952 a $23 \%$ en 2001. Basados en las estimaciones de inicios de la década de los 50 's, mediados de la década de los 80 's y de 1996 a 2001, al menos 13 especies no nativas han incrementado en abundancia, mientras algunas especies nativas han decrecido. El apacentamiento de ganado, la competencia con especie invasoras, la conversión a diferentes tipos vegetativos y el transporte de propágulos al sitio por vehículos y ganado, combinado con la dificultad de relocalizar especies raras son propuestas como las causas más probables de los cambios documentados.

ty, change in ecosystem function, and reduction in rangeland productivity (D'Antonio and Vitousek 1992, Campbell and Smith 2000). In particular, exotic annual grasses interfere significantly with native perennial grasses during all stages of growth (Hamilton et al. 1999), resulting in an increase in exotic annuals over time. Invading species can also differ functionally from the native species that they are replacing, resulting in a great overarching effect on ecosystems (Vitousek 1986).

Monitoring species compositional changes in California hardwood rangelands is essential for determining the sustainability of livestock grazing and necessary to address the lack of oak seedling survival. Because the understory of California's hardwood rangelands are dominated by exotic grasses and forbs, many lower in nutritional quality and palatability than native perennial species, the capacity of rangelands has been seriously decreased (Major 1955, Pettit et al. 1995). Annual grasses are adapted to heavy grazing and low nutrient availability (Jackson 1985), which has consequences for the way livestock grazing is practiced on site as well as the economic vitality of open range 
grazing operations. As range conditions deteriorate, livestock seek out less palatable plant species, increasing the use on these species, oak seedlings included. Additionally, the establishment of exotic annual grasses has been proposed as a limiting factor in the regeneration of some native oak species (Muick and Bartolome 1988, Gordon and Rice 1993).

Due to the scarcity of historic baseline information, few studies have examined long-term change on California rangelands. Using cover data from the 1930's, Holzman and Allen-Diaz (1991) documented 58 years of change in 21 blue oak (Quercus douglasii Hook. \& Arn.) woodland plots in California. Our study documents change over nearly a half-century by reconstructing the past flora of a hardwood rangeland in northwest California, comparing herbarium data to the modern flora. This was feasible due to the establishment of an extensive reference collection of vascular plants for the site in the early 1950's. A flora was later published (Murphy and Heady 1983) which included data on species abundance across the site from the early 1980's. This comprehensive set of scientific records, in combination with extensive documentation of landuse at the site, provided us with a means to identify newly established species and document changes in the relative abundance of some taxa.

\section{Study Site}

\section{Vegetation}

The study area encompasses the entire University of California Hopland Research and Extension Center, located in the interior north coast ranges of southeastern Mendocino County $\left(39^{\circ} 00^{\prime} \mathrm{N}\right.$, $\left.123^{\circ} 05^{\prime} \mathrm{W}\right)$. It encompasses nearly 2,168 hectares of moderately steep, predominately southwest-facing slopes in the Mayacmas Mountains, with elevations ranging from 183 to $914 \mathrm{~m}$. The natural vegetation reflects a mediterranean climate of hot dry summers and cool wet winters, with an average annual rainfall of $960 \mathrm{~mm}$. Oaks and other hardwoods are common overstory species of the lower elevation woodlands and include blue oak (Quercus douglasii Hook. \& Arn.), black oak ( $Q$. kelloggii Newb.), valley oak ( $Q$. lobata Nee), Oregon oak (Q. garryana Hook.), coast live oak ( $Q$. agrifolia $\mathrm{Nee})$, Shreve oak ( $Q$. parvula E. Greene var. shrevei (C.H. Muller) K. Nixon), California bay (Umbellularia californica (Hook. \& Arn.) Nutt.), Pacific madrone
(Arbutus menziesii Pursh), and California buckeye (Aesculus californicus (Spach) Nutt.). Grasslands and the understory of open oak woodland and savanna are dominated by non-native annual grasses such as slender wild oat (Avena barbata Link), big quaking grass (Briza maxima L.), hedgehog dogtail (Cynosurus echinatus L.), and barbed goatgrass (Aegilops triuncialis L.). Chaparral scrub consisting of chamise (Adenostoma fasciculatum Hook. \& Arn.), Arctostaphylos spp., Ceanothus spp., and Quercus spp., along with patches of closed cone pine (Pinus attenuata Lemmon) are common above $675 \mathrm{~m}$. Douglas fir (Pseudotsuga menziesii (Mirbel) Franco), California nutmeg (Torreya californica Torrey), and canyon live oak (Quercus chrysolepis Liebm.) form dense shaded canopies on steep north and east facing slopes. Numerous seasonal creeks, sag ponds, vernal pools and springs provide a diversity of wetland habitats and plant communities (Heise and Merenlender 1999).

\section{Historic Data}

The Center was established as a range experiment station in 1951. The following year, a botanical survey was initiated to document all species of vascular plants on the property. By 1954 nearly 450 species were recorded. During the next 30 years of sporadic collecting only 137 species were added to the flora, bringing the total to almost 600 . At this time a list of the vascular plants for the Center was published (Murphy and Heady 1983). Only a few more species were added to the flora through the 1980's and mid 1990's, bringing the total number of vascular species and infraspecific taxa to 612. Alfred $H$. Murphy, the Center's first superintendent, and Harold F. Heady, U.C. Berkeley Professor of Range Management, initiated the inventory, and alone contributed 1,177 specimens to the Center's herbarium, about $92 \%$ of the collection.

\section{Livestock and Forage Management}

Prior to the University's purchase of the property the area was used as a sheep range. Since then, between 1,500 and 2,000 sheep continue to use approximately $2 / 3$ of the Center. Much of the livestock grazing pressure across this range is light because of the terrain and dense wooded vegetation; the heaviest use occurs on approximately 300 ha and is concentrated in lambing and winter feeding pastures or seeded grassland near the headquarters area. Livestock are excluded from approximately 435 ha in designated "biological areas", research pastures, and steep, wooded terrain outside of fenced pasture boundaries. Rangeland improvement practices during the 1960's and 1970's, aimed at increasing agricultural production, resulted in the conversion of approximately 300 ha of oak woodland and chamise chaparral to exotic grassland (Murphy 1976, 1978). In addition, university staff and researchers intentionally introduced at least 19 exotic plant species. These were seeded into pastures following fire or other forms of clearing to improve range forage, and since have expanded their ranges well beyond the initial introduction sites. Some of the common species include smilo grass (Piptatherum miliaceum (L.) Cosson), harding grass (Phalaris aquatica L.), orchard grass (Dactylis glomerata L.), rose clover (Trifolium hirtum All.) and subterranean clover ( $T$. subterraneum L.).

\section{Methods}

Between 1996 and 2001 we conducted an extensive inventory of vascular plants across the entire Center. First, the information from over 1,275 specimen labels from the Center's herbarium was updated to reflect mis-identifications, recent scientific name changes, and reductions due to synonymy (Hickman 1993), and then incorporated into a database. From this, species lists with location, habitat, and collection date were produced to facilitate the relocation of previously recorded taxa. Most of the herbarium specimens (75\%) contained general location descriptions such as pasture name only, while the remaining $25 \%$ had more specific site locations. Because of the intensity and thoroughness during the first 3 years of the original botanical survey in the early 1950's, we assume that taxa not collected then were probably sparse, inaccessible, or absent. An extensive road system over 72 $\mathrm{km}$ in length facilitated access throughout the Center's property; roadless areas were surveyed on foot. Voucher specimens for previously unrecorded taxa were collected and deposited into the Center's herbarium.

Relative terms describing abundance at the collection site ("Sparse", "Occasional", "Numerous") were assigned to 479 specimens (313 species) that were collected between 1952 and 1954. This site-specific information provided a rough estimate of species abundance across the Center in cases where there were similar abundance estimates for multiple collections of the same species. In the early 1980's Murphy and Heady (1983) estimated the abundance of 600 
vascular plant species across the entire Center using similar non-absolute terms, which we adopted during our field work to provide consistency. Thus, for about half of the flora we were able to obtain comparable abundance estimates from the early 1950 's, early 1980's, and 1996 to 2001 , and for the entire flora between the early 1980 's, and 1996 to 2001. Given the subjectivity of these terms, we only present taxa that have undergone extreme declines or increases, thus representing notable change.

\section{Results}

\section{New Taxa}

The 1996 to 2001 inventory added 59 species (44 native and 15 non-native) in 29 families to the flora, bringing the total number of species and infra-specific taxa at the field station to 671 (Table 1). More than half (34) of the new additions were native dicots, followed by non-native dicots (14), native monocots (8), nonnative monocots (1), and fern and fern allies (2). Asteraceae was the most represented family with 7 native and 4 nonnative species, followed by Apiaceae, Cyperaceae, and Scrophulariaceae (Table $2)$. Of the 44 native species, 22 were found in areas where sheep have been excluded, such as the "Biological Areas", rock outcrops, or other areas inaccessible to livestock, 12 in areas lightly grazed, 6 in moderate, and 4 in sites with heavy grazing pressure. Of the 15 new nonnative species, 3 were found in ungrazed areas, 3 in lightly grazed, 2 in moderately grazed, 6 in heavy grazed areas, and 1 found throughout all grazing regimes. Almost half of all new species found occurred in wetland habitats such as vernal pools, sag ponds, springs, and seasonal creeks.

\section{Missing Taxa}

Species loss was chiefly confined to plants of low abundance and occurred across a wide variety of habitat types and grazing regimes. Of the original 612 species that were documented at the Center prior to this study, 34 native and 1 non-native species could not be relocated (Table 3). Over half of the missing species (21) were native dicots, followed by native monocots (13), and non-native dicots (1). Although 19 families were represented, Poaceae, Asteraceae, and Cyperaceae accounted for roughly half of the species lost. Thirteen of the missing species occurred on sites that receive heavy graz-
Table 1. Floristic summary data for the University of California Hopland Research and Extension Center, Calif.

\begin{tabular}{lcccc}
\hline \hline & & \multicolumn{2}{c}{ Native } & \multicolumn{2}{c}{ Non-Native } \\
Taxa & Families & Genera & Taxa & Taxa \\
\hline Ferns and Fern Allies & 10 & 16 & 18 & 1 \\
Gymnosperms & 3 & 5 & 4 & 102 \\
Dicots & 71 & 258 & 374 & 52 \\
Monocots & 11 & 75 & 120 & 155 \\
Total & 95 & 354 & 516 & \\
\hline
\end{tabular}

ing pressure, 3 on moderately grazed, 9 on lightly grazed, and 10 in areas with no grazing. A majority of the 35 species lost occurred in grassland, chaparral, or wetland habitats.

\section{Changes in Species Abundance}

Many non-native species presumed absent or sparse during the early 1950's have since undergone dramatic increases in abundance (Table 4). For example,
Table 2. New species found at the University of California Hopland Research and Extension Center, California during 1996-2001 inventory period. Habitat: $\mathbf{C}=$ chaparral, $\mathbf{G}=$ grassland, $\mathbf{H}=$ hardwood forest, $\mathbf{X}=$ xeric woodland, $\mathbf{O}=$ outcrop/crevice, $\mathbf{W}=$ wetland, $\mathbf{R}=$ roadcut. Grazing: $\mathbf{N}=$ none, $\mathrm{L}=$ light, $\mathrm{M}=$ moderate, $\mathrm{H}=$ heavy

\begin{tabular}{|c|c|c|c|}
\hline Species & Habitat & Grazing & Native \\
\hline $\begin{array}{l}\text { Dryopteridaceae } \\
\text { Athyrium alpestre var. americanum }\end{array}$ & $\mathrm{O}$ & $\mathrm{N}$ & $\mathrm{Y}$ \\
\hline $\begin{array}{l}\text { Selaginellaceae } \\
\text { Selaginella wallacei }\end{array}$ & $\mathrm{O}$ & $\mathrm{N}$ & $\mathrm{Y}$ \\
\hline $\begin{array}{l}\text { Apiaceae } \\
\text { Lomatium dissectum } \\
\text { Lomatium vaginatum } \\
\text { Oenanthe sarmentosa } \\
\text { Tauschia kelloggii } \\
\text { Torilis arvensis }\end{array}$ & $\begin{array}{c}\mathrm{O} \\
\mathrm{H} \\
\mathrm{W} \\
\mathrm{H} \\
\mathrm{X}, \mathrm{G}\end{array}$ & $\begin{array}{c}\mathrm{N} \\
\mathrm{N} \\
\mathrm{N} \\
\mathrm{L} \\
\mathrm{N}, \mathrm{L}, \mathrm{M}\end{array}$ & $\begin{array}{l}\mathrm{Y} \\
\mathrm{Y} \\
\mathrm{Y} \\
\mathrm{Y} \\
\mathrm{N}\end{array}$ \\
\hline $\begin{array}{l}\text { Asteraceae } \\
\text { Euthamia occidentalis } \\
\text { Gnaphalium luteo-album } \\
\text { Hesperevax acaulis var. ambusticola } \\
\text { Hesperevax sparsiflora } \\
\text { Layia septentrionalis } \\
\text { Solidago californica } \\
\text { Soliva sessilis } \\
\text { Stephanomeria elata } \\
\text { Tolpis barbata } \\
\text { Tracyina rostrata } \\
\text { Tragopogon porrifolius }\end{array}$ & $\begin{array}{c}\text { W } \\
\text { W } \\
\text { C } \\
\text { G } \\
\text { X } \\
\text { W } \\
\text { R } \\
\text { W } \\
\text { X } \\
\text { G } \\
\text { G }\end{array}$ & $\begin{array}{l}\mathrm{M} \\
\mathrm{H} \\
\mathrm{L} \\
\mathrm{L} \\
\mathrm{L} \\
\mathrm{L} \\
\mathrm{H} \\
\mathrm{L} \\
\mathrm{L} \\
\mathrm{H} \\
\mathrm{L}\end{array}$ & $\begin{array}{l}\mathrm{Y} \\
\mathrm{N} \\
\mathrm{Y} \\
\mathrm{Y} \\
\mathrm{Y} \\
\mathrm{Y} \\
\mathrm{N} \\
\mathrm{Y} \\
\mathrm{N} \\
\mathrm{Y} \\
\mathrm{N}\end{array}$ \\
\hline $\begin{array}{l}\text { Boraginaceae } \\
\text { Myosotis discolor }\end{array}$ & W & $\mathrm{N}$ & $\mathrm{Y}$ \\
\hline $\begin{array}{l}\text { Brassicaceae } \\
\text { Carderia draba } \\
\text { Erysimum capitatum }\end{array}$ & $\begin{array}{l}\mathrm{W} \\
\mathrm{O}\end{array}$ & $\begin{array}{l}\mathrm{N} \\
\mathrm{N}\end{array}$ & $\begin{array}{l}\mathrm{N} \\
\mathrm{Y}\end{array}$ \\
\hline $\begin{array}{l}\text { Campanulaceae } \\
\text { Heterocodon rariflorum }\end{array}$ & W & $\mathrm{L}$ & $\mathrm{Y}$ \\
\hline $\begin{array}{l}\text { Caprifoliaceae } \\
\text { Symphoricarpos mollis } \\
\text { Caryophyllaceae }\end{array}$ & $\mathrm{H}$ & $\mathrm{L}$ & $\mathrm{Y}$ \\
\hline $\begin{array}{l}\text { Sagina apetala } \\
\text { Scleranthus annuus ssp. annuus }\end{array}$ & $\begin{array}{l}\text { W } \\
\text { G }\end{array}$ & $\begin{array}{l}\mathrm{M} \\
\mathrm{L}\end{array}$ & $\begin{array}{l}\mathrm{Y} \\
\mathrm{N}\end{array}$ \\
\hline $\begin{array}{l}\text { Crassulaceae } \\
\text { Sedum obtusatum ssp. retusum }\end{array}$ & $\mathrm{O}$ & $\mathrm{N}$ & $\mathrm{Y}$ \\
\hline $\begin{array}{l}\text { Ericaceae } \\
\text { Arctostaphylos canescens ssp. sonomensis } \\
\text { Chimaphila menziesii }\end{array}$ & $\begin{array}{l}\mathrm{C} \\
\mathrm{H}\end{array}$ & $\begin{array}{l}\mathrm{L} \\
\mathrm{N}\end{array}$ & $\begin{array}{l}\mathrm{Y} \\
\mathrm{Y}\end{array}$ \\
\hline $\begin{array}{l}\text { Euphorbiaceae } \\
\text { Euphorbia spathulata }\end{array}$ & $X$ & $\mathrm{~L}$ & $\mathrm{Y}$ \\
\hline
\end{tabular}

(Table 2 continued on page 415) 
(Table 2 Continued).

\begin{tabular}{|c|c|c|c|}
\hline Species & Habitat & Grazing & Native \\
\hline \multicolumn{4}{|l|}{ Fabaceae } \\
\hline Lotus pinnatus & $\mathrm{W}$ & $\mathrm{N}$ & $\mathrm{Y}$ \\
\hline Trifolium gracilentum var. gracilentum & G & M & $\mathrm{Y}$ \\
\hline Vicia hirsuta & W & $\mathrm{N}$ & $\mathrm{N}$ \\
\hline \multicolumn{4}{|l|}{ Gentianaceae } \\
\hline Cicendia quadrangularis & $\mathrm{W}$ & $\mathrm{H}$ & $\mathrm{Y}$ \\
\hline \multicolumn{4}{|l|}{ Lamiaceae } \\
\hline Satureja douglasii & $\mathrm{H}$ & $\mathrm{N}$ & $\mathrm{Y}$ \\
\hline Lamium purpureum & $\mathrm{R}$ & $\mathrm{H}$ & $\mathrm{N}$ \\
\hline \multicolumn{4}{|l|}{ Linaceae } \\
\hline Linum bienne & W & $\mathrm{H}$ & $\mathrm{N}$ \\
\hline \multicolumn{4}{|l|}{ Onagraceae } \\
\hline Clarkia concinna ssp. concinna & $\mathrm{H}$ & $\mathrm{N}$ & $\mathrm{Y}$ \\
\hline Epilobium brachycarpum & W & $\mathrm{H}$ & $\mathrm{Y}$ \\
\hline \multicolumn{4}{|l|}{ Polemoniaceae } \\
\hline Gilia sinistra ssp. pinnatisecta & $\mathrm{C}$ & $\mathrm{N}$ & $\mathrm{Y}$ \\
\hline \multicolumn{4}{|l|}{ Polygonaceae } \\
\hline Rumex conglomeratus & W & M & $\mathrm{N}$ \\
\hline \multicolumn{4}{|l|}{ Portulacaceae } \\
\hline Claytonia exigua & $\mathrm{O}$ & $\mathrm{N}$ & $\mathrm{Y}$ \\
\hline \multicolumn{4}{|l|}{ Portulacaceae } \\
\hline Claytonia exigua & $\mathrm{O}$ & $\mathrm{N}$ & $\mathrm{Y}$ \\
\hline \multicolumn{4}{|l|}{ Rubiaceae } \\
\hline Sherardia arvensis & W & $\mathrm{N}$ & $\mathrm{N}$ \\
\hline \multicolumn{4}{|l|}{ Scrophulariaceae } \\
\hline Collinsia parviflora & $\mathrm{X}$ & M & $\mathrm{Y}$ \\
\hline Cordylanthus pilosus & $\mathrm{X}$ & $\mathrm{N}$ & $\mathrm{Y}$ \\
\hline Parentucellia viscosa & $\mathrm{W}, \mathrm{R}$ & $\mathrm{H}$ & $\mathrm{N}$ \\
\hline Veronica anagallis-aquatica & W & $\mathrm{H}$ & $\mathrm{N}$ \\
\hline \multicolumn{4}{|l|}{ Solanaceae } \\
\hline Solanum americanum & W & $\mathrm{N}$ & $\mathrm{Y}$ \\
\hline \multicolumn{4}{|l|}{ Valerianaceae } \\
\hline \multicolumn{4}{|l|}{ Verbenaceae } \\
\hline Phyla nodiflora & G & $\mathrm{H}$ & $\mathrm{Y}$ \\
\hline Verbena lasiostachys & W & $\mathrm{N}$ & $\mathrm{Y}$ \\
\hline \multicolumn{4}{|l|}{ Cyperaceae } \\
\hline Carex barbarae & W & $\mathrm{N}$ & $\mathrm{Y}$ \\
\hline Carex comosa & W & $\mathrm{N}$ & $\mathrm{Y}$ \\
\hline Carex globosa & $\mathrm{H}$ & $\mathrm{N}$ & $\mathrm{Y}$ \\
\hline Carex subfusca & W & M & $\mathrm{Y}$ \\
\hline Scirpus californicus & $\mathrm{W}$ & $\mathrm{N}$ & $\mathrm{Y}$ \\
\hline \multicolumn{4}{|l|}{ Orchidaceae } \\
\hline Corallorhiza maculata & $\mathrm{H}$ & $\mathrm{N}$ & $\mathrm{Y}$ \\
\hline \multicolumn{4}{|l|}{ Poaceae } \\
\hline Festuca arundinacea & $\mathrm{G}$ & $\mathrm{L}$ & $\mathrm{N}$ \\
\hline Melica hardfordii & $\mathrm{H}$ & $\mathrm{L}$ & $\mathrm{Y}$ \\
\hline \multicolumn{4}{|l|}{ Typhaceae } \\
\hline Sparganium eurycarpum ssp. eurycarpum & W & $\mathrm{N}$ & $\mathrm{Y}$ \\
\hline
\end{tabular}

pennyroyal (Mentha pulegium L.), an herbaceous perennial first collected on the Center in 1969, now dominates the margins of several permanent ponds and seeps in grazed and ungrazed sites alike. Barbed goatgrass (Aegilops triuncialis L.), another extremely invasive plant, was first collected here in 1961 and is now the dominant species on approximately 125 ha of serpentine grassland. The currently widespread and abundant Japanese Hedge-Parsley (Torilis arvensis (Hudson) Link.) was first collected in 1996, which suggests a rapid increase in abundance over the past 10 years. Noted as "sparse" and "occasional" respectively in 1983, big quakinggrass (Briza maxima L.) and hedgehog dogtail (Cynosurus echinatus L.) now comprise the dominant understory of oak woodlands on several south and southwest-facing slopes.
While many introduced species have become established and have increased in abundance at the Center, some native herbaceous perennials, such as rancher's fireweed (Amsinckii menziesii (Lehm.) Nelson \& J.F. Macbr.), owl's clover (Castilleja densiflora (Benth.) Chuang \& Heckard), Rigiopappus leptocladus A. Gray, and modesty (Whipplea modesta Torrey), which were considered numerous in the early fifties, are now sparse in occurrence. Other species that were common in occurrence in the fifties and now missing include Brewer's milkvetch (Astragalus breweri A. Grey), varied-leaf Collomia (Collomia heterophylla Hook.), and tufted hairgrass (Deschampsia cespitosa (L.) Beauv. var. cespitosa). Because of the subjective nature of the abundance measures, smaller changes for other species have undoubtedly occurred but cannot be presented with confidence.

\section{Discussion}

The initial plant survey at the Center in the early 1950's attempted to catalog all the known vascular plants, establishing valuable baseline floristic information for a 2,168 ha rangeland. Our study represents the first step in documenting the floristic changes that have occurred since the early 1950 's. As a result of our inventory we observed the following trends: 1) the occurrence of new native taxa previously undetected, 2) new non-native species have been established at the site, 3) some already established non-native species have greatly increased in abundance, 4) some missing taxa are clearly extirpated from the site, and 5) the missing taxa include some species that may be too rare to relocate over the course of the study. As expected, we added more non-native species to the Center's flora, whereas the addition of native species gave us confidence in the thoroughness of our survey methods. From records at the Center there is evidence that some rangeland management practices led to species loss and the spread of exotic plants. Access to management records that can help explain possible causes of change is an advantage of doing this type of study on a public research facility.

We documented an increase in nonnative species richness which is characteristic of the spread of invasive species in western lowland California (Randall et al. 1998). Non-natives at the Center are being added to the flora at a rate of 1.3 species per year, while several of those already 
Table 3. Plants that could not be relocated at the University of California Hopland Research and Extension Center, California following a 1996-2001 inventory. Habitat: $R=$ roadcut, $C=$ chaparral, $\mathbf{G}=$ grassland, $\mathbf{H}=$ hardwood forest, $\mathbf{W}=$ wetland, $\mathbf{X}=$ xeric woodland. Grazing: $\mathbf{N}=$ none, $\mathrm{L}=$ light, $\mathrm{M}=$ moderate, $\mathrm{H}=$ heavy

\begin{tabular}{|c|c|c|c|}
\hline Species & Habitat & Grazing & Native \\
\hline $\begin{array}{l}\text { Apiaceae } \\
\text { Perideridia gairdneri }\end{array}$ & G & $\mathrm{N}$ & $\mathrm{Y}$ \\
\hline $\begin{array}{l}\text { Asteraceae } \\
\text { Aster radulinus } \\
\text { Cirsium remotifolium } \\
\text { Lessingia nemaclada } \\
\text { Microseris laciniata ssp. laciniata }\end{array}$ & $\begin{array}{c}\mathrm{H} \\
\mathrm{G} \\
\mathrm{GL} \\
\mathrm{G}\end{array}$ & $\begin{array}{l}\mathrm{H} \\
\mathrm{N} \\
\mathrm{Y} \\
\mathrm{H}\end{array}$ & $\begin{array}{l}\mathrm{Y} \\
\mathrm{Y}\end{array}$ \\
\hline $\begin{array}{l}\text { Boraginaceae } \\
\text { Plagiobothrys stipitatus var. micranthus }\end{array}$ & W & $\mathrm{H}$ & Y \\
\hline $\begin{array}{l}\text { Brassicaceae } \\
\text { Tropidocarpum gracile }\end{array}$ & G L, & $\mathrm{H}$ & $\mathrm{Y}$ \\
\hline $\begin{array}{l}\text { Cistaceae } \\
\text { Helianthemum suffrutescens }\end{array}$ & $\mathrm{C}$ & $\mathrm{L}$ & Y \\
\hline $\begin{array}{l}\text { Crassulaceae } \\
\text { Sedum radiatum }\end{array}$ & $\mathrm{C}$ & $\mathrm{N}$ & Y \\
\hline $\begin{array}{l}\text { Fabaceae } \\
\text { Astragalus breweri } \\
\text { Gentianaceae }\end{array}$ & G & $\mathrm{H}$ & Y \\
\hline Centaurium davyi & $W$ & $\mathrm{~N}$ & $\mathrm{Y}$ \\
\hline $\begin{array}{l}\text { Loasaceae } \\
\text { Mentzelia laevicaulis } \\
\text { Mentzelia micrantha }\end{array}$ & $\begin{array}{l}\mathrm{R} \\
\mathrm{R}\end{array}$ & $\begin{array}{l}\mathrm{L} \\
\mathrm{L}\end{array}$ & $\begin{array}{l}\mathrm{Y} \\
\mathrm{Y}\end{array}$ \\
\hline $\begin{array}{l}\text { Malvaceae } \\
\text { Abutilon theophrasti }\end{array}$ & $\mathrm{W}$ & $\mathrm{N}$ & $\mathrm{N}$ \\
\hline $\begin{array}{l}\text { Onagraceae } \\
\text { Camissonia californica } \\
\text { Clarkia unguiculata }\end{array}$ & $\begin{array}{l}\mathrm{W} \\
\mathrm{R}\end{array}$ & $\begin{array}{l}\mathrm{L} \\
\mathrm{L}\end{array}$ & $\begin{array}{l}\mathrm{Y} \\
\mathrm{Y}\end{array}$ \\
\hline $\begin{array}{l}\text { Orobanchaceae } \\
\text { Orobanche uniflora }\end{array}$ & $\mathrm{G}$ & $\mathrm{H}$ & $\mathrm{Y}$ \\
\hline $\begin{array}{l}\text { Papaveraceae } \\
\text { Dendromecon rigida }\end{array}$ & $\mathrm{CN}$ & Y & \\
\hline $\begin{array}{l}\text { Polemoniaceae } \\
\text { Collomia diversifolia } \\
\text { Collomia heterophylla }\end{array}$ & $\begin{array}{l}\mathrm{H} \\
\mathrm{X}\end{array}$ & $\begin{array}{l}\mathrm{H} \\
\mathrm{N}\end{array}$ & $\begin{array}{l}\mathrm{Y} \\
\mathrm{Y}\end{array}$ \\
\hline $\begin{array}{l}\text { Polygonaceae } \\
\text { Chorizanthe polygonoides }\end{array}$ & $\mathrm{C}$ & $\mathrm{N}$ & $\mathrm{Y}$ \\
\hline $\begin{array}{l}\text { Ranunculaceae } \\
\text { Aquilegia eximia }\end{array}$ & $\mathrm{C}$ & $\mathrm{N}$ & $\mathrm{Y}$ \\
\hline $\begin{array}{l}\text { Cyperaceae } \\
\text { Cyperus erythrorhizos } \\
\text { Cyperus squarrosus } \\
\text { Eleocharis radicans }\end{array}$ & $\begin{array}{l}\text { W N, } \\
\text { W } \\
\text { W }\end{array}$ & $\begin{array}{l}\mathrm{M} \\
\mathrm{M} \\
\mathrm{M}\end{array}$ & $\begin{array}{l}\mathrm{Y} \\
\mathrm{Y} \\
\mathrm{Y}\end{array}$ \\
\hline $\begin{array}{l}\text { Liliaceae } \\
\text { Fritillaria recurva } \\
\text { Lilium rubescens }\end{array}$ & $\begin{array}{l}\mathrm{C} \\
\mathrm{C}\end{array}$ & $\begin{array}{l}\mathrm{L} \\
\mathrm{N}\end{array}$ & $\begin{array}{l}\mathrm{Y} \\
\mathrm{Y}\end{array}$ \\
\hline $\begin{array}{l}\text { Poaceae } \\
\text { Agrostis hallii } \\
\text { Calamagrostis koelerioides } \\
\text { Calamagrostis purpurascens } \\
\text { Calamagrostis rubescens } \\
\text { Deschampsia cespitosa } \\
\text { Festuca viridula } \\
\text { Leersia oryzoides } \\
\text { Pleuropogon californicus }\end{array}$ & $\begin{array}{c}\mathrm{X} \\
\mathrm{C} \\
\mathrm{C} \mathrm{H} \text {, } \\
\mathrm{H} \\
\mathrm{W} \\
\mathrm{C} \\
\mathrm{W} \\
\mathrm{W}\end{array}$ & $\begin{array}{l}\mathrm{H} \\
\mathrm{L} \\
\mathrm{L} \\
\mathrm{H} \\
\mathrm{H} \\
\mathrm{L} \\
\mathrm{H} \\
\mathrm{H}\end{array}$ & $\begin{array}{l}\mathrm{Y} \\
\mathrm{Y} \\
\mathrm{Y} \\
\mathrm{Y} \\
\mathrm{Y} \\
\mathrm{Y} \\
\mathrm{Y} \\
\mathrm{Y}\end{array}$ \\
\hline
\end{tabular}

established have undergone dramatic local range extensions. Most of the new introduced species were found in areas accessed by livestock or adjacent to roads where they could have been carried in by areas, and are conspicuously absent in dense chaparral, shaded hardwood forest, and on steep rocky outcrops. Roughly one third of the Center's 155 non-native species are annual grasses, followed by annual forbs primarily in Asteraceae and Fabaceae. Today, non-native plant species on the Center comprise $23 \%$ of the total flora compared to $19 \%$ in the early 1950 's,

By the time the University of California acquired the property in 1951, the nonnative flora was already well established. Herbarium records indicate that by 1954 over 90 introduced species occurred on the Center; of these, 22 were considered numerous at their collection sites. Thirty years later there were 136 introduced species, and by 2001 the number had grown to 155 (Fig. 1). This represents a $71 \%$ increase in non-native species over a period of 45 years. In contrast, the entire state of California saw a $31 \%$ increase in non-native plant species for a similar period between 1959 and 1998 (Randall et al. 1998).

Many of the new native species found during our inventory were likely overlooked during earlier surveys because of their rarity or locations that were difficult to access. For example, spikemoss (Selaginella wallacei Hieron.) was common on several north-facing boulders camouflaged with mosses and ferns, and an individual wallflower (Erysimum capitatum (Douglas) E. Greene) was located within a crevice high on a steep cliff face. Many others were found on steep wooded slopes outside of fenced pastures. Four plants considered rare in California were also found (Skinner and Pavlik 1994). The Bristly sedge (Carex comosa Boott) is considered rare across its entire range in several western states in the U.S., beaked Tracyina (Tracyina rostrata S.F. Blake) is known from fewer than a dozen populations in northwest California, Sonoma manzanita (Arctostaphylos canescens Eastw. ssp. sonomensis (Eastw.) P. Wells) occurs on chaparral sites in Northwest California, and Colusa Layia (Layia septentrionalis Keck) is a serpentine endemic of California's Interior Coast Ranges. Documenting these locations adds to an important body of information for conservation biologists and resource protection agencies monitoring rare species occurrences.

Over half of the missing taxa were originally recorded as "rare" or "sparse" and may have been overlooked during our inventory. These species were originally collected in upland areas with little or no grazing. Furthermore, there was nothing about the species composition at the origi- 


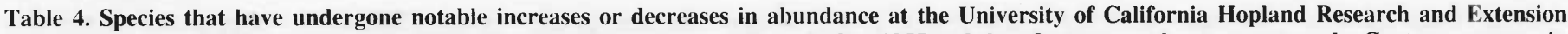

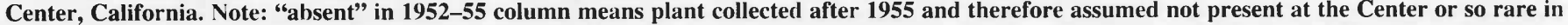
occurrence it was missed during first years of inventory.

\begin{tabular}{|c|c|c|c|c|}
\hline Species & Exotic & $1952-55$ & 1983 & $1996-01$ \\
\hline Amsinckii menziesii (Fiddleneck) & & numerous & occasional & sparse \\
\hline Castilleja densiflora (Owl's Clover) & & numerous & occasional & sparse \\
\hline Rigiopappus leptocladus & & numerous & numerous & sparse \\
\hline Whipplea modesta (Yerba de Selva) & & numerous & occasional & sparse \\
\hline Aegilops triuncialis (Barhed Goatgrass) & $\mathrm{x}$ & absent & occasional & numerous \\
\hline Baccharis pilularis (Coyote Brush) & & sparse & occasional & numerous \\
\hline Briza maxima (Big Quakinggrass) & $\mathrm{x}$ & absent & sparse & numerous \\
\hline Carduus pycnocephalus (Italian Thistle) & $\mathrm{x}$ & sparse & numerous & numerous \\
\hline Cerastium arvense (Field Chickweed) & $\mathrm{x}$ & absent & occasional & numerous \\
\hline Cynosurus echinatus (Hedgehog Dogtail) & $\mathrm{x}$ & occasional & occasional & numerous \\
\hline Dactylis glomerata (Orchardgrass) & $\mathbf{x}$ & sparse & occasional & numerous \\
\hline Holcus lanatus (Velvetgrass) & $\mathrm{x}$ & sparse & sparse & numerous \\
\hline Mentha pulegium (Pennyroyal) & $\mathrm{x}$ & absent & sparse & numerous \\
\hline Parentucellia viscosa & $\mathrm{x}$ & absent & absent & occasional \\
\hline Petrorhagia dubia & $\mathrm{x}$ & absent & rare & numerous \\
\hline Soliva sessilis & $\mathrm{x}$ & absent & absent & occasional \\
\hline Taeniatherum caput-medusae (Medusahead) & $\mathrm{x}$ & occasional & numerous & numerous \\
\hline Torilis arvensis (Japanese Hedge-parsley) & $\mathrm{x}$ & absent & absent & numerous \\
\hline
\end{tabular}

nal collection sites that would suggest species replacement. At the same time, rare plants are more susceptible to stochastic events, so it can't be ruled out entirely that some may have gone locally extinct. It is difficult to differentiate between what might have been a stochastic extinction and the inability to locate a species because of its rarity: Fischer and Stocklin (1997) noted a similar problem comparing old and new records of plant occurrence on calcareous grasslands in the Swiss Jura Mountains. They mentioned the possibility that species could have been missing in the new records without actually having gone extinct, if the old and new records were not taken at the same location. Similarly, many of our specimens had only vague location descriptions, such as "upper Orchard Pasture" or "Lake Biological Area", making it more difficult to locate the original collection site; more detailed location information was available for only 9 of the 43 missing plants.

Conversions of vegetation type appear to be responsible for the extirpation of at least 5 species. Pine grass (Calamagrostis rubescens Buckley) and serpentine Collomia (Collomia diversifolia E. Greene), the latter an uncommon California endemic, were last collected in the spring of 1957 . In the summer of the same year the woody vegetation of the 26 ha watershed where these plants occurred was removed and burned, and later seeded with a mixture of non-native clovers and grasses (Murphy 1976). Semaphore grass (Pleuropogon californicus (Nees) Vasey) and popcorn flower (Plagiobothrys stipitatus (E. Greene) I.M. Johnston var. micranthus (Piper) I.M. Johnston) were last collected in 1952 and 1953 along a seasonal watercourse; since then this pasture has been tilled and seeded numerous times with non-native grasses and clovers (unpublished pasture histories). Reed grass (Calamagrostis koelerioides Vasey) likely occurred on a chaparral site that has since been cleared and seeded with non-native grasses and forbs.

Thirteen of the 35 species that could not be relocated occurred originally on sites that have been under heavy grazing pressure. Heavy grazing can jeopardize the sustainability of grassland ecosystems by reducing soil fertility and water-holding capacity (Dormaar and Willms 1998), which can then lead to dominance of exotic annual species. At the same time, these sites have also undergone dramatic increases in several exotic species, notably big quaking grass, hedgehog dogtail, and barbed goatgrass in grasslands, and velvet grass (Holcus lanatus L.) and pennyroyal in wetland habitats (Table 4). The potential impact from either of these threats may play a role in the observed species loss. In particular, barbed goatgrass now dominates serpentine grassland sites and has become a threat to rangelands across California (Kennedy 1928, Peters et al. 1996). Previously, serpentine grasslands did not support extensive annual grass cover due to the low nutrient levels (Huenneke et al.1990) and had been regarded as refugia for California's native plants (Harrison 1999, Murphy and Ehrlich 1989). Therefore, documenting the spread of this invasive annual grass is of particular concern for native plant conservation.

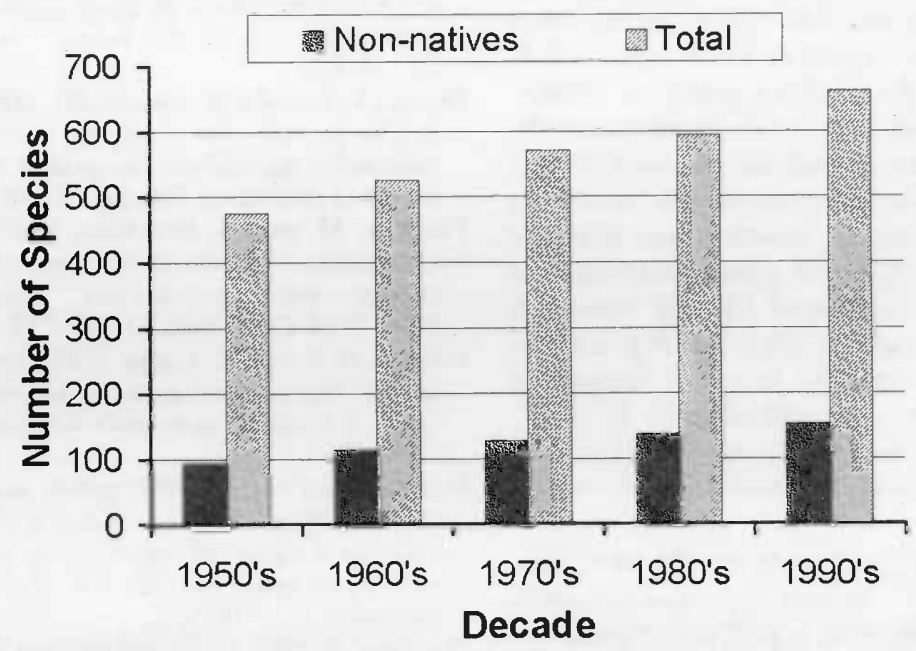

Fig. 1. Number of vascular plant species reported for the University of California Hopland Research and Extension Center, California. Over $2 / 3$ of the total number of species to date were collected between 1952 and 1954 following the establishment of the field station. 
The relatively recent establishment and spread of species such as big quaking grass, hedgehog dogtail, barbed goatgrass, velvet grass, and pennyroyal also has consequences for ecosystem function. Eviner and Chapin (2001) found differences in decomposition rates, net nitrogen cycling rates, and phosphorus availability between single species plots planted at the Center. In particular, barbed goatgrass plots had greatly enhanced net nitrification, and supported the highest gopher activity, suggesting that this species may provide a more stable soil surface preferred by gophers. This example illustrates how changes in the composition and relative abundance of herbaceous species can directly influence ecosystem function, resulting in alterations to the habitat that can further affect vertebrate densities. Another consequence of the spread of competitive annual grasses for hardwood rangeland conservation may be reduced oak regeneration, due primarily to competition for water (Gordon and Rice 1993). In addition to the consequences these exotics have for ecosystem function and biodiversity conservation, the quality of the livestock forage has been reduced. For example, pennyroyal, barbed goatgrass, hedgehog dogtail, and big quaking grass, have all undergone substantial increases in abundance at the Center, yet are highly unpalatable to livestock.

Early research at the Center focused on vegetation type conversions and reseeding with non-native species in order to enhance forage production and water yield, but this was not without costs. The conversion of a wooded 86 ha watershed resulted in a dramatic increase of 2 weedy species along with multiple soil slips and increases in sediment discharge (Pitt et al. 1978, Heady and Pitt 1979). On the other hand, fire has recently been used to dramatically reduce barbed goatgrass infestations in 2 pastures while simultaneously increasing the abundance of meadow barley (Hordeum brachyantherum Nevski), a native perennial bunchgrass; thereby improving forage for sheep (DiTomaso et al. 2001). The trend toward research directed at oak woodland and grassland ecosystems and the fact that rangeland conversion is no longer done for livestock production will undoubtedly slow the spread and establishment of invasive species.

Hardwood rangelands are the most biologically rich habitat type in California (Pavlik et al. 1991), making it essential that we monitor changes to their flora over time. Continued surveys at the Center will help verify local extinction and document new losses, as well as new additions to the flora. To better demonstrate the spread of invasive species, a monitoring program should be established that includes mapping the distribution of non-native species through time using the Center's existing Geographic Information System. While we note shifts in land-use as a likely cause for the observed changes to the flora, long-term experiments on the effects of livestock grazing and species introductions are essential to test the direct contribution that grazing and exotics have on native flora. In addition, a quantitative study comparing vegetation composition and abundance in similar plant communities on comparable soil types between grazed and ungrazed sites would be useful. Studies of this sort would complement this one and provide a better understanding of species turnover and the associated causes in north coast hardwood rangelands.

\section{Literature Cited}

Campbell, B.D. and D.M.S. Smith. 2000. A synthesis of recent global change research on pasture and rangeland production: Reduced uncertainties and their management implications. Agr. Ecosyst. Enviroment 82: 39-55.

D'Antonio, C.M. and P.M. Vitousek. 1992. Biological invasions by exotic grasses, the grass/fire cycle, and global change. Ann. Rev. Ecol. Syst. 23:63-87.

de Nevers, G. 1985. Pepperwood flora. Pepperwood Ranch Natural Preserve. Sonoma County, CA. California Academy of Sciences, San Francisco, Calif.

DiTomaso, J.M., K.L. Heise, G.B. Kyser, A.M. Merenlender, and R.J. Keiffer. 2001. Carefully timed burning can control barb goatgrass. Cal. Agr. 55(6):47-52.

Dormaar J.F. and W.D. Willms. 1998. Effect of forty-four years of grazing on fescue grassland soils. J. Range Manage. 51:122-126.

Eviner, V.T. and F.S. Chapin III. 2001. Plant species provide vital ecosystem functions for sustainable agriculture, rangeland management and restoration. Cal. Agr. 55(6):54-59.

Fischer, M. and J. Stocklin. 1997. Local extinctions of plants in remnants of extensively used calcareous grasslands 1950-1985. Cons. Biol. 11:727-737.

Gordon, D. R. and K. J. Rice 1993. Competitive effects of grassland annuals on soil water and blue oak (Quercus douglasii) seedlings. Ecol. 74: 68-82.

Hamilton, J.G., C. Holzapfel, and B.E. Mahall. 1999. Coexistence and interference between a native perennial grass and nonnative annual grasses in California. Oecologia 121:518-526.

Harrison, S. 1999. Local and regional diversity in a patchy landscape: Native, alien, and endemic herbs on serpentine. Ecol. 80:70-80.
Heady, H.F. 1977. Valley grassland. Pp. 491514 in M.G. Barbour and J. Major (eds.), Terrestrial vegetation of California. John Wiley and Sons, New York.

Heady, H.F. and M.D. Pitt. 1979. Reactions of northern California grass-Woodland to vegetational type conversions. Hilgardia 47:51-73.

Heise, K.L. and A.M. Merenlender. 1999. Flora of a vernal pool complex in the Mayacmas Mountains of southeastern Mendocino County, California. Madrono 46: 38-45.

Hickman, J. 1993. The jepson manual: Higher plants of California. University of California Press, Berkeley and Los Angeles, Calif.

Holzman B.A. and B.H. Allen-Diaz. 1991. Vegetation change in blue oak woodlands in California. USDA For. Serv. Gen. Tech. Rep. PSW-126.

Huenneke, L.F., S.P.Hamburg, R. Koide, H.A. Mooney, and P.M. Vitousek. 1990. Effects of soil resources on plant invasion and community structure in Californian [USA] serpentine grassland. Ecol. 71:478-491.

Jackson, L.E. 1985. Ecological origins of California's mediterranean grasses. J. Biogeog. 12:349-361.

Kennedy, P.B. 1928. Goatgrass or wild wheat (Aegilops triuncialis). J. Amer. Soc. Agron. 20:1292-1296.

Knops, J.M.H., J.R. Griffin, and A.C. Royalty. 1995. Introduced and native plants of the Hastings Reservation, central coastal California: A comparison. Biol. Cons. 71:115-123.

Mack, R. N. 1989. Temperate grasslands vulnerable to plant invasions: characteristics and consequences. Pp. 155-179 In J.A. Drake, H.A. Mooney, F. di Castri, R.H. Groves, F.J. Kruger, M. Rejmanek, and M. Williamson (eds.), Biological invasions: A global perspective. John Wiley \& Sons, Chichester, N.Y.

Major, J. 1955. Weeds on California rangelands. Cal. Agr. 9:3-4.

Mooney, H.A. and J.A. Drake. 1987. The ecology of biological invasions. Environ. 29:10-37.

Muick, P. C. and J. W. Bartolome. 1988. Factors associated with oak regeneration in California. Pp 86-91, In: T.R. Plumb and N. H. Pillsbury (Tech. Coord.). Proc. Symp. Multiple-use Management of California's Hardwood Resources. USFS Gen. Tech. Rep. PSW-100.

Murphy, A.H. 1976. Watershed management increases rangeland productivity. Cal. Agr. 30:16-21.

Murphy, A.H. 1978. Benefits of chaparral improvement to livestock and wildlife. Proc. Ann. Calif. Weed Conf. 30:84-91.

Murphy, A.H. and H.F. Heady. 1983. Vascular plants of the Hopland Field Station, Mendocino County, California. Wasmann J. Biol. 41:53-96.

Murphy, D.D. and P.R. Ehrlich. 1989. Conservation biology of California's remnant native grasslands. Pp 201-212. In: L.F. Huenneke and H.F. Mooney (eds.), Grassland structure and function: California annual grassland. Kluwer, Dordrecht. 
Pavlik, B.M., P.C. Muick, S.G. Johnson, and M. Popper. 1991. Oak of California, Cachuma Press and the California Oak Foundation. Los Olivos, Calif. 184 pp.

Peters, A., D.E. Johnson and M.R. George. 1996. Barb goatgrass: A threat to California rangelands. Rangelands 18(1): 8-10.

Pettit, N.E., R.H. Forend, and P.G. Ladd. 1995. Grazing in remnant woodland vegetation: Changes in species composition and life form groups. J. Veg. Sci. 6: 121-130.

Pitt, M.D., R.H. Burgy, and H.F. Heady. 1978. Influences of brush conversion and weather patterns on runoff from a northern California watershed. J. Range Manage. 31:23-27.
Randall, J.M., M. Rejmánek, and J.C. Hunter. 1998. Characteristics of the exotic flora of California. Fremontia 26:3-12.

Rejmanek, M., C.D. Thomsen, and I.D. Peters. 1991. Invasive vascular plants of California. Pp. 81-101. In: R.H. Groves, and F. di Castri (eds.). Biogeography of mediterranean invasions. Cambridge University Press, Cambridge.

Skinner M.W. and B.M. Pavlik. 1994. California Native Plant Society's Inventory of Rare and Endangered Vascular Plants of California. Special Publication No.1 (fifth edition). CNPS.
Vitousek, P.J. 1986. Biological invasions and ecosystem properties: Can species make a difference? Pp. 163-178 In: H.A. Mooney and J. Drake (eds.), Biological invasions of North America and Hawaii. Springer-Verlag, New York, N.Y. 


\title{
Fingerprint composition of seedling root exudates of select- ed grasses
}

\author{
JOHAN F. DORMAAR, BONNIE C. TOVELL, AND WALTER D. WILLMS
}

Authors are Soil Scientist (retired), Microbiologist, and Range Ecologist, Research Centre, Agriculture and Agri-Food Canada, P. O. Box 3000, Lethbridge, Alberta, Canada TIJ $4 B 1$

\begin{abstract}
The competitiveness of plants within a community is dictated to some extent by their association with microorganisms in the soil. That association is affected by root exudates and possibly by their quality. The competitiveness of species under various grazing regimes has been defined by their response to grazing as decreaser, increaser, or invader. To test the hypothesis that there are recognisable differences in the chemical fingerprints of the root exudates of decreasers, increasers and invaders, seeds of 8 grasses, representing these 3 designations, were germinated and grown for 2 weeks in a root exudate trapping system in the laboratory. Tentative identification of the suite of compounds recovered from the root exudates by a solvent extraction technique was done with the help of gas chromatography/mass spectrometry and authentic samples. Eleven identified compounds, present in all exudates as major peaks, but absent in the blanks, were selected for semi-quantitatively comparing the 3 grazing response groups. For all 11 compounds, there was always at least 1 of the grazing response groups that had the highest percentages. That is to say, they were qualitatively, based on the $11 \mathrm{com}$ pounds selected, but not quantitatively similar.
\end{abstract}

Key Words: organic acids, native grasses, introduced grasses, soil quality, soil chemical properties

Rangeland plant species have been classified as decreasers, increasers, or invaders (Bedell 1998). Decreaser species often dominate the undisturbed grassland communities and normally have large plants. Decreaser species derive their classification from their response to grazing pressure. Increaser species are those that replace the decreasers and are more resistant to grazing pressure while invader species are normally aliens that are capable of competing in a grazed or ungrazed environment.

The consequence of replacing the dominant species in a plant community is a seral stage that can be resistant to succession (Dormaar and Willms 1990, Dormaar et al. 1994). For example, blue grama (Bouteloua gracilis (HBK.) Lag. Ex Steud) appears to

The technical assistance of R. R. James with the initial stages of this research project and of J. Elder who conducted the GC-MS analyses is gratefully acknowledged.

Mention of a trademark, proprietary product or vendor does not constitute a guarantee or warrantee of the product by Agriculture and Agri-Food Canada and does not imply its approval to the exclusion of other products or vendors that may also be suitable.

Lethbridge Research Centre Contribution No.387-0089

Manuscript accepted 17 Sept. 01.

\section{Resumen}

La competitividad de las plantas dentro de una comunidad es dictada en parte por su asociación con los microorganismos del suelo. Esa asociación es afectada por los exudados de la raíz y posiblemente por su calidad. La competitividad de las especies bajo varios regímenes de apacentamiento ha sido definida por su respuesta al apacentamiento como especies decrecientes, crecientes o invasoras. Para probar la hipótesis de que hay diferencias reconocibles en la huella química de los exudados de la raíz de especies decrecientes, creciente e invasoras se tomaron semillas de 8 zacates que representan estas 3 designaciones y se geminaron y crecieron por dos semanas en un sistema de laboratorio que atrapaba los exudados de la raíz. La identificación tentativa del grupo de compuestos de los exudados de la raíz recuperados mediante una técnica de extracción con solventes se hizo con la ayuda de cromatografía de gases y espectrofotometría de masas y muestras auténticas. Once compuestos identificados, presentes en todos los exudados como picos principales, pero ausentes en los blancos, se seleccionaron para comparar semicuantitativamente los 3 grupos de respuesta al apacentamiento. Para todos los 11 compuestos, siempre hubo al menos 1 de los grupos de repuesta al apacentamiento que tuvo los mas altos porcentajes. Es decir, ellos fueron cualitativamente, basados en los 11 compuestos seleccionados, pero no cuantitativamente similares.

resist displacement by its associated climax dominant species. Similarly, crested wheatgrass (Agropyron cristatum (L.) Gaertn.), an introduced species, is a strong competitor in Mixed Prairie communities with the ability to invade and colonize undisturbed native communities (Caldwell 1991, Trent et al. 1993).

The competitiveness of plants within a community is dictated to some extent by their association with microorganisms in the soil such as the vesicular-arbuscular mycorrhizal type. That association is affected by root exudates and possibly by their chemical quality (Bokhari 1978, Klein et al. 1988, Foster and Dormaar 1991). Inhibitors of nitrifying bacteria were found in the root extracts of increaser and invader species (Neal 1969). Conversely, Bremner and McCarty (1993), based on an intensive literature survey, concluded that there was no satisfactory evidence to support the hypothesis that grasses inhibit nitrification in soils by exuding substances that retard oxidation of $\mathrm{NH}_{4}+$ by nitrifying microorganisms. A later study by Neal (1973) showed that invader species had increased phosphatase activity, reflecting a potential for higher $\mathrm{P}$ uptake, in the surrounding soil as com- 
pared to dominant, co-dominant, or increaser species.

Organic acids play a prominent role in cell metabolism, affect rhizosphere $\mathrm{pH}$, and microbial activity (Curl and Truelove 1986). They are good metal-chelating compounds and aid in the absorption and translocation of nutrient elements. Rice (1984), after having summarised what could be found in the literature, concluded that organic acids are important in allelopathy. It was speculated that i) 3 major long-chain fatty acids, i.e., palmitic, stearic, and arachidic acids, identified from soil in rough fescue (Festuca campestris Rydb.) grasslands that were in good condition because of low grazing pressure, could well contribute to the resistance of those grasslands to the encroachment of invading species (Dormaar and Willms 1992) and ii) dioctyl adipate or di(2-ethylhexyl)phthalate could be linked to inhibition of nitrification (Dormaar et al. 1994). Nevertheless, in spite of these roles and speculations, organic acids are rarely included in lists of exudate components (Curl and Truelove 1986).

Before establishing if there is a possible relationship between exudate composition and the competitive status of plant species, fingerprint organic acid compositions, in the form of gas chromatographic patterns, of root exudates from the first 2 weeks of growth of a number of decreaser, increaser, and invader grass species will have to be obtained. This would then allow testing the hypothesis that there are recognisable semi-quantitative differences in the chemical fingerprints of root exudates from plants that fall within these designations.

\section{Materials and Methods}

\section{Species Selected}

Seeds of 5 native and 3 introduced, invading grass species were collected in the field: Needle-and-thread (Stipa comata Trin. and Ruper.), Western wheatgrass (Agropyron smithii Rydb.), and rough fescue were selected to represent decreaser species; blue grama and June grass (Koeleria cristata (L.) Pers.) were selected to represent increaser species; and crested wheatgrass, Russian wildrye (Elymus junceus Fisch.) and timothy (Phleum pratense L.) were selected to represent invader species. The seeds were collected by glove-covered hands. They were then placed in paper bags and stored at room temperature. To simulate field conditions, the seeds were not sterilised prior to use.

\section{Collection of Root Exudates}

Seeds were placed in a thin bed of finely (particle size 0.5 to $1.0 \mathrm{~mm}$ ) crushed lava rock over a deeper bed of $2-\mathrm{cm}$ size lava rock. Blanks were the same but without the seeds. The lava rock was obtained from a garden centre. After emergence, they were thinned down to aim for the same amount (100 if possible; if less they were counted) of seedlings and allowed to grow for 2 weeks after germination. The seeds and plants were irrigated with 50-ml 0.1strength Hoagland solution. This was then circulated at the rate of $20-\mathrm{ml} \mathrm{min}^{-1}$ by airlift. Water was added to compensate for losses due to aspiration and evaporation.

The exudates were trapped with a continuous hydrophobic root exudate trapping system (Tang and Young 1982). This technique was selected as a first approximation of either different compounds or the same compounds at different quantities. To eliminate equipment related contaminants, a smaller, all glass and Teflon ${ }^{\mathrm{TM}}$ system was designed. Prior to assemblage of the system, both the $2-\mathrm{cm}$ size and finely crushed lava rock were heated to $900^{\circ}$ $\mathrm{C}$, while the all quartz glass wool was heated to $600^{\circ} \mathrm{C}$. The quartz glass wool was placed at the bottom of a 725-ml funnel-shaped growth reservoir. Next, the 2$\mathrm{cm}$ size lava rocks were added which in turn were covered with the finely crushed lava rock. The thistle of the funnel was attached, via a taper-ground joint, to a 19 x $150 \mathrm{~mm}$ glass tube. Root exudates were collected on a $6-\mathrm{cm}$ resin bed of $\mathrm{Bio}$

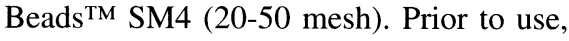
the Bio Beads ${ }^{\mathrm{TM}}$ were Soxhlet-extracted (Tang and Young 1982) with acetone, acetonitrile, and diethyl ether each for 24 hours to eliminate any potential impurities in the product, and stored in glass-distilled methanol. All solvents were glass distilled OmniSolv ${ }^{\mathrm{TM}}$ grade. When in the collection cylinder, the Bio Beads ${ }^{\mathrm{TM}}$ were rinsed with 10-bed volumes of double, glass distilled water. The containers and collection cylinders were wrapped in aluminum foil. Duplicate runs were made of a control, without plants, with each set of 4-plant systems. Runs were continued until 2 consecutive ones of a plant species were obtained with good duplication. That is, considering all steps adding to errors and the accumulative errors of the calculations, replicate runs with about $3 \%$ variation were considered acceptable precision for this study.

\section{Analysis}

Following the 2-week growth period, the resin beds were rinsed with 5-bed vol- umes of glass distilled water to eliminate any water-soluble compounds. Next, the beads were extracted with 5-bed volumes of glass distilled methanol. The methanol extract was reduced on a rotary evaporator $\left(60^{\circ} \mathrm{C}, 30 \mathrm{kPa}\right)$. The remaining $2 \mathrm{ml}$ was adjusted to $\mathrm{pH} 2.0$ with $3 \mathrm{~N} \mathrm{HCl}$. Ten microlitres of $1-\mathrm{mg} \mathrm{ml}^{-1}$ methanol stock of suberic acid (octanedioc or 1,6-hexanedicarboxylic acid) were added to serve as internal standard. This mixture was then extracted 3 times with $25-\mathrm{ml} \mathrm{CH}_{2} \mathrm{Cl}_{2}$, dried over anhydrous $\mathrm{Na}_{2} \mathrm{SO}_{4}$, and reduced to $1-\mathrm{ml}$ with a stream of $\mathrm{N}_{2}$ at room temperature. One half $\mathrm{ml}$ of the sample was esterified by adding 1-ml 14\% boron trifluoride in methanol and placing it in a $60^{\circ} \mathrm{C}$ water bath for $10 \mathrm{~min}$. Following cooling, 1-ml saturated sodium chloride in glass distilled water was added. After shaking, 1-ml hexane was added. After $10 \mathrm{~min}, 400 \mu \mathrm{l}$ of the hexane solution was placed in a vial for analysis.

Initial analyses $(1 \mu \mathrm{l})$ were carried out with a Hewlett Packard GC 5890 Series II Plus, using a 30-m long capillary column (i.d. $0.320 \mathrm{~mm}$ ) wall-coated with $5 \%$ diphenyl-95\% dimethyl polysiloxane (DB5) with helium as the carrier gas (about 1 $\left.\mathrm{ml} \mathrm{min}{ }^{-1}\right)$. The operating conditions were: $50^{\circ} \mathrm{C}$ for $1 \mathrm{~min}$, then $25^{\circ} \mathrm{C} \mathrm{min}^{-1}$ to $100^{\circ}$ $\mathrm{C}$ for $1 \mathrm{~min}$, then $3^{\circ} \mathrm{C} \min ^{-1}$ to $275^{\circ} \mathrm{C}$ for $1 \mathrm{~min}$; the injection port temperature was $250^{\circ} \mathrm{C}$, while the flame ionization detector temperature was $275^{\circ} \mathrm{C}$. The qualitative analyses were carried out with a Hewlett Packard GC-MS data system. Following tentative identification, the spectra of the major peaks selected were compared with authentic samples.

Over 70 compounds, many in minute quantities, were tentatively identified. Of these, only 11, which were present in all exudates across the spectra but absent in the blanks, were selected for comparison. They were then calculated as percent against the standard (octanediocic acid) and adjusted for $100 \%$ germination of 100 seeds. Another way could have been to normalise the exudate composition by root weight. However, root washing, no matter how carefully done, leads to losses of root hairs and thus considered inappropriate. The presence of seed remnants and the ash content of the root mass made weighing the burned lava rock before and after inappropriate as well. In this study, precision of the chromatographic output was considered of greater value in fingerprint separation than accuracy.

A test of the identified compounds among the grazing response groups was evaluated as a simple ANOVA where each 
Table 1. Tentatively identified methylated carboxylic acids (A) in root exudates collected over a 2-week period of growth following germination as determined by GL-MS.

\begin{tabular}{|c|c|c|c|c|c|c|c|c|}
\hline & \multirow{3}{*}{$\begin{array}{c}\text { Stipa } \\
\text { comata }\end{array}$} & \multicolumn{3}{|c|}{ Indigenous } & Increasers & \multicolumn{3}{|c|}{$\begin{array}{c}\text { Non-indigenous } \\
\text { Invaders }\end{array}$} \\
\hline & & Agropyron & Festuca & Bouteloua & Koeleria & Agropyron & Elymus & Phleum \\
\hline & & smithii & campestris & gracilis & cristata & cristatum & junceus & pratense \\
\hline Octanoic A & $7^{1}$ & 15 & 8 & 36 & 30 & 12 & 17 & 22 \\
\hline Nonaoic A & 27 & 29 & 30 & 93 & 82 & 116 & 99 & 115 \\
\hline 1,2 -Benzenedicarboxylic $A^{2}$ & 29 & 25 & 27 & 14 & 10 & 9 & 12 & 19 \\
\hline Dodecanoic A & 11 & 20 & 8 & 11 & 8 & 58 & 41 & 60 \\
\hline Nonanedioic A & 8 & 15 & 6 & 11 & 5 & 27 & 28 & 29 \\
\hline Tridecanoic A & 32 & 29 & 31 & 4 & 6 & 14 & 12 & 13 \\
\hline Teradecanoic A & 10 & 10 & 12 & 93 & 87 & 27 & 35 & 29 \\
\hline Pentadecanoic A & 3 & 9 & 10 & 42 & 40 & 11 & 16 & 9 \\
\hline 2-HexadecanoicA (formII) & 45 & 18 & 19 & 16 & 18 & 79 & 85 & 101 \\
\hline 1,2 -Benzenedicarboxylic $\mathrm{A}^{2}$ & 39 & 48 & 69 & 7 & 13 & 24 & 14 & 20 \\
\hline E-9-Octadecenoic A & 9 & 14 & 6 & 24 & 33 & 99 & 113 & 106 \\
\hline
\end{tabular}

${ }_{1}^{1}$ The numbers represent the percent against the standard (Octanedioic A) and are adjusted for $100 \%$ germination of 100 seeds.

${ }^{2}$ Dimethyl and butyl-ethyl, respectively.

species represented a replicate. Consequently, the design was unbalanced with 3 decreaser, 2 increaser, and 3 invader replicates. Treatment means were compared with single degree of freedom contrasts.

\section{Results and Discussion}

All 11 tentatively identified compounds (Table 1) revealed separation $(\mathrm{P}<0.01)$ among the grazing response groups (Table 2) suggesting specific semi-quantitative fingerprint patterns. There was no consistent ranking in the magnitude of the organic compounds produced by each group. Nevertheless, for all 11 compounds, there was always at least 1 of the grazing response groups that had the highest percentages. In spite of all precautions, because of the polystyrene composition of the Bio Beads ${ }^{\mathrm{TM}}$, the blank runs still had 'noise.' It is, therefore, acknowledged that by concentrating on the 11 major peaks not present in the 'noise', the potential significance of minute quantities of specific compounds, present in some but possibly absent in other root exudates, but masked by the 'noise', could potentially give qualitative evidence for the decreaser/increaser/invader designation.

It is unfortunate that the level of 1,2-benzenedicarboxylic acid or phthalic acid must always be suspect when working with soil extracts. Due to the increased use of plastics over the last 50 years (Dormaar 1982), phthalic acid has more or less become a universal contaminant. However, under the conditions of the experiment the assumption is being made that the phthalic acid measured is a true product of the root exudates obtained and processed, since it was not present in the blanks.

Soil quality changes manifest them- selves through changes in quantity and quality of the chemical changes of root exudates (Dormaar and Willms 1995). Although decreasers are plants that may well succumb to grazing pressure, increasers and invaders may partially invade space vacated by the decreasers, the chemical potential always exists that root exudates, albeit ephemeral and minor in terms of contribution to total soil $\mathrm{C}$, may prevent decreasers from returning or plants in general from re-entering higher successional states. Callaway and Aschehoug (2000) found that diffuse knapweed's (Centaurea diffusa Lam.) advantage against North American species appeared to be due to differences in the effects of its root exudates and how these root exudates affected competition for resources. No specific compounds were identified.

Dormaar et al. (1980) and Dormaar (1982) demonstrated that gas chromatographic patterns of solvent extractable organic acids from Chernozemic soils could be related to the vegetation growing on those soils. However, this present study

Table 2. Statistical comparisons of tentatively identified methylated carboxylic acids (A) of root exudates among species groups (shown in Table 1).

\begin{tabular}{|c|c|c|c|c|}
\hline & $\begin{array}{c}\text { Treatment } \\
\text { effect }\end{array}$ & $\begin{array}{l}\text { Decreaser vs } \\
\text { Increaser }\end{array}$ & $\begin{array}{c}\text { Decreaser vs } \\
\text { Invader }\end{array}$ & $\begin{array}{c}\text { Increaser vs } \\
\text { Invader }\end{array}$ \\
\hline Octanoic A & 0.008 & $\begin{array}{l}-----P r o b \\
0.003\end{array}$ & 0.122 & 0.012 \\
\hline Nonaoic A & $<0.001$ & $<0.001$ & $<0.001$ & 0.017 \\
\hline 1,2-Benzenedicarboxylic $\mathrm{A}^{1}$ & 0.009 & 0.007 & 0.006 & 0.710 \\
\hline Dodecanoic A & 0.002 & 0.642 & 0.002 & 0.002 \\
\hline Nonanedioic A & 0.002 & 0.633 & 0.002 & 0.002 \\
\hline Tridecanoic A & $<0.001$ & $<0.001$ & $<0.001$ & 0.001 \\
\hline Teradecanoic A & $<0.001$ & $<0.001$ & 0.001 & $<0.001$ \\
\hline Pentadecanoic A & $<0.001$ & $<0.001$ & 0.150 & $<0.002$ \\
\hline 2-HexadecanoicA (formII) & 0.002 & 0.392 & 0.002 & $<0.001$ \\
\hline 1,2-Benzenedicarboxylic $\mathrm{A}^{\prime}$ & 0.012 & 0.007 & 0.012 & 0.372 \\
\hline E-9-Octadecenoic A & $<0.001$ & 0.017 & $<0.001$ & $<0.001$ \\
\hline
\end{tabular}

Dimethyl and Butyl-ethyl, respectively. did not elucidate why some plants are decreasers, while others are increasers or invaders, even though they did have different semi-quantitative gas chromatographic fingerprint outputs. Without knowing what even the tentatively compounds do in the rhizosphere, no conclusions towards this can even be proposed. Neither may the identified compounds be necessarily in the soil as the same semiquantitative fingerprint. For example, Biondini et al. (1988) established that microorganisms, in sterile and non-sterile fritted clay used as growth media, significantly increased root exudation of $A$. cristatum and $A$. smithii, but had no effect on $B$. gracilis. Their data suggested that an introduced plant species may be markedly different from native species in the shortgrass steppe in terms of exudate releases. No specific compounds were identified.

This study was designed, as a first step, to obtain a qualitative comparison of a group of compounds identified in root exudates collected over a 2 -week period. Little, if any is known about the potential 
effect of the individual compounds identified. Although the bleeding of resins will have to be explored further, it is suggested that the next step ought to be to take the 11 compounds identified and to test their effect on some sensitive plants, such as lettuce or cucumber, as a first approximation. However, even if this leads to further specific insights of the compounds identified, in the final analysis it may well be a combination, and most likely synergistic at that, of a number of factors, such as resource competition (moisture, nutrients), aggressive growth behaviour, disease resistance, and chemical differences in root exudates, that enable plants to act as decreasers, increasers or invaders. In terms of the study under discussion it can be concluded, as Dormaar and Willms (1990) did with $\mathrm{NaOH}$-soluble organic acids between soils of needle-and-thread and blue grama range, and cropland, that the suite of constituents selected and identified were qualitatively, but not semi-quantitatively similar.

\section{Literature Cited}

Bedell, T.E. 1998. Glossary of terms used in range management, $4^{\text {th }}$ edition. Glossary Update Task Group, Soc. Range Manage., Denver, Colo.
Biondini, M., D.A. Klein, and E.F. Redente. 1988. Carbon and nitrogen losses through root exudation by Agropyron cristatum, A. smithii and Bouteloua gracilis. Soil Biol. Biochem. 20: 477-482.

Bokhari, U.G. 1978. Allelopathy among prairie grasses and its possible ecological significance. Ann. Bot. 42: 127-136.

Bremner, J.M. and G.W. McCarty. 1993. Inhibition of nitrification in soil by allelochemicals derived from plants and plant residues. In: J.-M. Bollag and G. Stozky (eds.), Soil Biochemistry 8: 181-218. Marcel Dekker Inc., New York, N.Y.

Caldwell, M. 1991. Underground events may be root of grass behavior. Utah Science 53 (2): 51.

Callaway, R.M., and E.T. Aschehoug. 2000. Invasive plants versus their new and old neighbours: a mechanism for exotic invasion. Sci. 290: 521-523.

Curl, E.A. and B. Truelove. 1986. The rhizosphere. Springer-Verlag, Berlin, Germany.

Dormaar, J.F. 1982. Aliphatic carboxylic acids in Chernozemic soils. Can. J. Soil Sci. 62:487-494.

Dormaar, J.F. and W.D. Willms. 1990. Effect of grazing and cultivation on some chemical properties of soils in the Mixed Prairie. J. Range Manage. 43:456-460.

Dormaar, J.F., and W.D. Willms. 1992. Water-extractable organic matter from plant litter and soil of rough fescue grassland. J. Range Manage. 45:152--158.

Dormaar, J.F. and W.D. Willms. 1995. Root mass and quality as a measure of range health, p.121. In: Proc. $5^{\text {th }}$ Int. Rangeland Congress, Volume 1, Salt Lake City, Ut.
Dormaar, J.F., B.W. Adams, and W.D. Willms. 1994. Effect of grazing and abandoned cultivation on a Stipa-Bouteloua community. J. Range Manage. 47:28-32.

Dormaar, J.F., A. Johnston, and S. Smoliak. 1980. Organic solvent-soluble organic matter from soils underlying native range and crested wheatgrass in southeastern Alberta, Canada. J. Range Manage, 33:99-101.

Foster, R.C. and J.F. Dormaar. 1991. Bacteria-grazing amoebae in situ in the rhizosphere. Biol. Fertil. Soils 11: 83-87.

Klein, D.A., B.A. Frederick, M. Biondini, and M.J. Trlica. 1988. Rhizosphere microorganism effects on soluble amino acids, sugars and organic acids in the root zone of Agropyron cristatum, A. smithii and Bouteloua gracilis. Plant Soil 110:19-25.

Neal, Jr., J.L. 1969. Inhibition of nitrifying bacteria by grass and forb root extracts. Can. J. Microbiol. 15:633-635.

Neal, Jr., J.L. 1973. Influence of selected grasses and forbs on soil phosphatase activity. Can. J. Soil Sci. 53:119-121.

Rice, E.L. 1984. Allelopathy, $2^{\text {nd }}$ ed. Academic Press, Inc., Orlando, Fla.

Tang, C.-S. and C.C. Young. 1982. Collection and identification of allelopathic compounds from the undisturbed root system of bigalta limpograss (Hemarthria altissima). Plant Physiol. 69: 155-160.

Trent, J.D., A.J. Svejcar, and G.J. Bethlenfalvay. 1993. Growth and nutrition of combinations of native and introduced plants and mycorrhizal fungi in a semiarid range. Agr., Ecosystems, Environ. 45: 13-23. 


\section{Book Reviews}

Restoration Ecology and Sustainable Development. Edited by Krystyna M. Urbanska, Nigel R. Webb, and Peter J. Edward. 2000. Cambridge University Press, United Kingdom. 397 p. US\$39.95 paper. ISBN 0-521-59989.

Throughout my formal education I have found, used, and been given numerous definitions of the terms ecosystem and ecosystem processes. Many of these definitions have differed depending on the prevailing political environment, the country, the region, the context. Restoration Ecology and Sustainable Development resolves those inconsistencies. In this book, ecology is discussed as a changing science, evolving as knowledge and the political situations surrounding our environment have developed.

Part 1 introduces the meaning of restoration ecology in detail. Particular emphasis is placed on the phrase "restoration ecology" and the scope of its meaning.

Part 2 follows this holistic approach to restoration ecology. Its development over time is emphasized. Ecology has come from being a barely recognized discipline to a multi-disciplinary, highly researched, recognized science. The authors and editors do not try to offer the "right" solution per se, but give numerous accounts of successes and failures in the restoration process. Overall, they provide the reader with a better understanding of all the encompassing factors involved in restoration ecology and sustainable development.

The contributing authors provide a range of examples from North America, Iceland, Australia, and Europe. Each of these case studies presents issues beyond that of restoration ecology, looking at impacts on various temporal and spatial scales. Bakker et al. contribute an account of coastal salt marshes, outlining impacts from $700-500 \mathrm{BC}$ to the present day. Throughout this discussion are restoration successes and failures. This open-minded approach to restoration is a continual theme throughout the book.

Part 3 illustrates the need for recognizing restoration ecology research worldwide. Jonathon Major, the author of the Australian case study, raises an interesting issue in Figure 11.2. This figure is a graphical representation of the origin of references cited in issues of Restoration in Ecology in America, Britain, Australia, and elsewhere. This "concerning observation" shows an overwhelming tendency to cite from only the country where the issue is authored.

Jonathon Major, and the other contributing authors in Part 3 highlight the importance of looking beyond national borders. Every continent is different, as is every state, county, and region. Each situation is unique. As a result of this uniqueness, situations need to be treated individually. To learn from mistakes and benefit from others' knowledge, we must expand our resources.

This concept of expansion is developed further in the final part of the book. Expansion or restoration is illustrated, and rightly so, as encompassing much more than just the ecology of an area. Many of the contributing authors give examples which illustrate the importance of incorporating ecological, economic, and social aspects.

Without overloading the reader with extensive technical language and equations, the book balances between scientific analyses and management options. The management options are abundant and described effectively. Restoration ecology is acknowledged as a vast field encompassing a broad array of changing variables. The book suggests and illustrates enormous potential for recovery in a vast range of habitat and land types. In Restoration Ecology and Sustainable Development, each author contributes an important aspect of restoration and sustainable development. The reader is left with a feeling of satisfaction that so many things can be accomplished, and are being accomplished, in the field of restoration ecology.-Tamara Boland, University of New England, Armidale, New South Wales, Australia.

The Political Economy of Agricultural, Natural Resources, and Environmental Policy Analysis. By Wesley F. Peterson. 2001. Iowa State University Press, Ames, Iowa, USA. 373 p. US\$69.95 hardbound. ISBN 0-8138-04329.

This book, written by a professor of agricultural economics at the University of Nebraska, is intended to serve as a textbook for upper-division courses in the economic analysis of agricultural and natural resources policy. Part 1, comprised of 6 chapters, establishes the theoretical foundations of policy analysis. Chapter 1 categorizes situations requiring collective action and public policy. Collective action then is analyzed in an economic 'market' setting (Chapter 2), and a political setting through an economic lens (i.e., public choice theory, Chapter 5). Chapters 3 and 4 cover standard resource-economics topics including the fundamental theorems of welfare economics, public goods, externalities, common pool resources, and perfect and imperfect competition. Chapter 6 addresses philosophical issues providing the foundation for ethical considerations of economic justice and equality in formulating public policies.

Part II, comprised of 9 chapters, translates the theoretical foundation into practical tools for policy analysis and applies them to a number of case studies. Chapter 7 covers benefit-cost analysis, which is applied to 2 case studies in Chapter 8 (revitalization of the banana industry in West Africa) and Chapter 9 (groundwater contamination). Chapter 10 presents partial equilibrium analysis, which is applied to case studies of the U.S. sugar program in Chapter 11 and international trade conflicts over genetically modified organisms in Chapter 12. Chapter 13 discusses multisector, systems, and economy-wide models. These tools are applied to study the North American Free Trade Agreement in Chapter 14. Chapter 15 concludes the book with a discussion of the place of policy analysis in the policy process.

In my opinion, this is an excellent book for use in advanced undergraduate and master's level courses in natural resource and environmental economics. The book is well organized and the writing is very clear. Introductions to the 2 parts of the book and the constituent chapters provide students with a useful road map for the information to follow. The theoretical section in most textbooks can be rather dry, but the book avoids this problem by interlacing the discussion with several interesting real-world policy examples. The examples are presented in an evenhanded manner that allows students to evaluate both sides of complex issues. The book's progression from theory to practical policy assessment tools applied to real-world case studies is a very effective way to teach policy analysis.

The book's use of mathematics is also very effective. The mathematics of the subject matter is nicely presented in shaded boxes and in appendices. This allows the material to be taught equally well with or without the mathematics, depending on the mathematical proficiency of the class.

In sum, the book effectively combines economics, philosophy, political science, and mathematics to give students a very wellrounded presentation of the economic analysis of agricultural and natural resource policy. The extensive use of case studies and real-world examples gives students excellent experience in learning how theory and practical analytical tools can work together to produce meaningful analysis.-Ray Huffaker, Department of Agricultural Economics, Washington State University, Pullman, Washington. 


\section{INSTRUCTIONS FOR AUTHORS (from revised Handbook and Style Manual)}

\section{Eligibility}

The Journal of Range Management is a publication for reporting and documenting results of original research and selected invitational papers. Previously published papers are unacceptable and will not be considered for publication. Exceptions to this criterion are research results that were originally published as department research summaries, field station reports, abstracts of presentations, and other obscure and nontechnical handout publications. Manuscripts submitted to the JRM are the property of the Journal until published or released back to the author(s). Manuscripts may not be submitted elsewhere while they are being considered for this journal. Papers not accepted for publication are automatically released to the authors.

\section{Kinds of Manuscripts}

Journal Articles report original findings in Plant Physiology, Animal Nutrition, Ecology, Economics, Hydrology, Wildlife Habitat, Methodology, Taxonomy, Grazing Management, Soils, Land Reclamation (reseeding), and Range Improvement (fire, mechanical chemical). Technical Notes are short articles (usually less than 2 printed pages) reporting unique apparatus and experimental techniques. By invitation of the Editorial Board, a Review or Synthesis Paper may be printed in the journal. Viewpoint articles or Research Observations discussing opinion or philosophical concepts regarding topical material or observational data are acceptable. Such articles are identified by the word viewpoint or observations in the title.

\section{Manuscript Submission}

Contributions are addressed to the Editor, Gary Frasier, Journal of Range Management, 7820 Stag Hollow Road, Loveland, Colorado 80538. Manuscripts are to be prepared according to the instructions in the Journal's Handbook and Style Manual. If the manuscript is to be one of a series, the Editor must be notified. Four copies of the complete manuscript, typed on paper with numbered line spaces are required. Authors may retain original tables and figures until the paper is accepted, and send good quality photocopies for the review process. Receipt of all manuscripts is acknowledged at once, and authors are informed about subsequent steps of review, approval or release, and publication.

Manuscripts that do not follow the directives and style in Journal handbook will be returned to the authors before being reviewed. A manuscript number and submission date will be assigned when the paper is received in the appropriate format.

\section{Manuscript Review}

Manuscripts are forwarded to an Associate Editor, who usually obtains 2 or more additional reviews. Reviewers remain anonymous. These reviewers have the major responsibility for critical evaluation to determine whether or not a manuscript meets scientific and literary standards. Where reviewers disagree, the Associate Editor, at his discretion, may obtain additional reviews before accepting or rejecting a manuscript. The Associate Editor may also elect to return to the author those manuscripts that require revision to meet format criteria before the Journal review.

The Associate Editor sends approved manuscripts, with recommendations for publication, to the Editor, who notifies the author of a projected publication date. Manuscripts found inappropriate for the $J R M$ are released to the author by the Associate Editor. Manuscripts returned to an author for revision are returned to the Associate Editor for final acceptability of the revision. Revisions not returned within 6 months, are considered terminated. Authors who consider that their manuscript has received an unsatisfactory review may file an appeal with the Editor. The Editor then may select another Associate Editor to review the appeal. The Associate Editor reviewing the appeal will be provided with copies of an correspondence relating to the original review of the manuscript. If the appeal is sustained, a new review of the manuscript may be implemented at the discretion of the Editor.

Authors should feel free to contact the Associate Editor assigned to their manuscript at any stage of the review process: to find out where the paper is in the process; to ask questions about reviewer comments; to ask for clarification or options if a paper has been rejected.

\section{Page Proofs}

Page proofs are provided to give the author a final opportunity to make corrections of errors caused by editing and production. Authors will be charged when extensive revision is required because of author changes, even if page charges are not assessed for the article. One author per paper will receive page proofs. These are to be returned to the Production Editor, 3059A Hwy 92, Hotchkiss, Colorado 81419-9548, within 48 hours after being received. If a problem arises that makes this impossible, authors or their designates are asked to contact the Production Editor immediately, or production and publication may proceed without the author's approval of his edited manuscript.

\section{Page Charges and Reprint Orders}

Authors are expected to pay current page charges. Since most research is funded for publication, it will be assumed that the authors are able to pay page charges unless they indicate otherwise in writing, when submitting a manuscript. When funds are unavailable to an author, no page charges will be assessed. Only the Editor will have knowledge of fund status of page charges; the Associate Editors and reviewers will accept or reject a manuscript on content only.

An order form for reprints is sent to one author with the page proofs. Information as to price and procedure are provided at that time. The minimum order is 100 ; no reprints are provided free of charge. We are also providing electronic reprints for a cost of $\$ 50.00$.

\section{Basic Writing Style}

Every paper should be written accurately, clearly, and concisely. It should lead the reader from a clear statement of purpose through materials and methods, results, and to discussion. The data should be reported in coherent sequence, with a sufficient number of tables, drawings, and photographs to clarify the text and to reduce the amount of discussion. Tables, graphs, and narrative should not duplicate each other.

Authors should have manuscripts thoroughly reviewed by colleagues in their own institution and elsewhere before submitting them. Peer review before submission insures that publications will present significant new information or interpretation of previous data and will speed $J R M$ review process.

Particular attention should be given to literature cited: names of authors, date of publication, abbreviations or names of journals, titles, volumes, and page numbers.

It is not the task of Associate Editors or Journal reviewers to edit poorly prepared papers or to correct readily detectable errors. Papers not properly prepared will be returned to the author. 